Gorgias Précis Portfolios 9

\title{
The Historiography of
}

Music in Global Perspective 


\section{The Historiography of Music in Global Perspective}

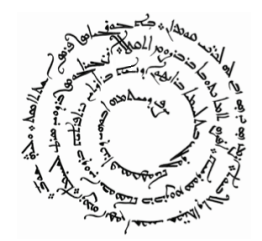




\section{Gorgias Précis Portfolios}

9

Gorgias Précis Portfolios gather the collected essays of established scholars into an easily accessible and durable format. Also included in this series are collections of essays in conference or Festschrift format from different scholars but united around a common theme. 


\title{
The Historiography of Music in Global Perspective
}

\author{
Edited by \\ Sam Mirelman
}

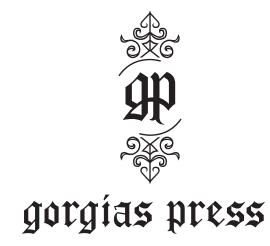

2010 
Gorgias Press LLC, 954 River Road, Piscataway, NJ, 08854, USA www.gorgiaspress.com

Copyright (C) 2010 by Gorgias Press LLC

All rights reserved under International and Pan-American Copyright Conventions. No part of this publication may be reproduced, stored in a retrieval system or transmitted in any form or by any means, electronic, mechanical, photocopying, recording, scanning or otherwise without the prior written permission of Gorgias Press LLC.

2010

$\kappa$,

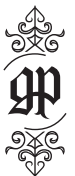

ISBN 978-1-61143-669-3

ISSN 1935-3871

Printed in the United States of America 


\section{TABLE OF CONTENTS}

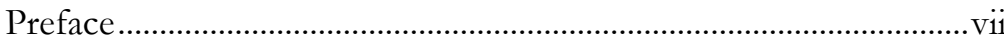

Remembering Music in Early Greece .................................................... 1

John C. Franklin

Interpreting Non-European Perceptions and Representations of Early Modern European Music

David R. M. Irving

From Music Archaeology to Historiography:

Andean Music Archaeology and Musical Instruments,

Singing and Dancing in Guaman Poma's

Nuéva Crónica y Bien Gobierno.

Ellen Hickmann

Music-Archaeological Research

on Pre-Columbian Music Cultures, 1880-1920

Arnd Adje Both

Antiquarians, Archaeologists and Music

in Nineteenth Century London:

Early Conversations in Music's Prehistory.

Graeme Lawson

The False Decipherment of Cuneiform 'Notation'

in the Early Twentieth Century.

Sam Mirelman

Studies of Ancient Nordic Music, 1915-1940

Gjermund Kolltveit

Music Archaeology in Scandinavia, 1800-1990

Cajsa S. Lund 



\section{PREFACE}

This book is based on a Study Day which I convened at the Institute of Musical Research (University of London) on July 4, 2009. The authors address issues surrounding the perception of music's past in various historical periods, and various parts of the world. Many of the essays in this volume offer evaluations of episodes in the history of musical enquiry which are barely known in (ethno-) musicology, as well as archaeology or anthropology. Such episodes of enquiry or scholarship are important for several reasons. They may or may not contribute towards a greater factual understanding of music history, but they certainly have much to offer in terms of improving our understanding of wider cultural history, as well as musical thought, during the period in question. In particular, studies concentrating on the nineteenth and early twentieth centuries allow for a closer examination of the context in which the modern disciplines of musicology and ethnomusicology emerged. Furthermore, such episodes contextualise the history and background through which the contemporary discipline of music archaeology developed in the twentieth century (Lund). Indeed, this collection of articles highlights the extent to which the serious, methodical study of music's distant past has been a flourishing field of research since at least the mid nineteenth century until the present.

The order of articles follows a generally chronological order, not in terms of the object of study, but rather in terms of the period of scholarship under consideration. Thus, the earliest evidence for the writing of what might be called music history comes from ancient Greece (Franklin). This is followed by a long hiatus before we reach the early modern period, as well as the nineteenth and twentieth centuries. At least half of the articles are concerned with European perspectives of music history, where the object of study is either European or non-European. However, two 
of the articles address the perception of music by non-Europeans, either of their own culture and/or of others, in the early modern period (Irving and Hickmann).

I would like to thank Graham Lawson, whose ongoing research (with Kolltveit and Lund) into the history of musicarchaeological research prompted my idea for the Study Day. I would also like to thank Katharine Ellis and Valerie James at the Institute for Musical Research, for hosting the meeting which resulted in this book.

Sam Mirelman 


\title{
REMEMBERING MUSIC IN EARLY GREECE
}

\author{
JOHN C. FRANKLIN
}

This paper contemplates various ways that the ancient Greeks preserved information about their musical past. Emphasis is given to the earlier periods and the transition from oral/ aural tradition, when self-reflective professional poetry was the primary means of remembering music, to literacy, when festival inscriptions and written poetry could first capture information in at least roughly datable contexts. But the continuing interplay of the orall aural and written modes during the Archaic and Classical periods also had an impact on the bistorical record, which from ca. 400 onwards is represented by historiographical fragments. The sources, methods, and motives of these early treatises are also examined, with special attention to Hellanicus of Lesbos and Glaucus of Rhegion. The essay concludes with a few brief comments on Peripatetic historiography and a selective catalogue of music-historiographical titles from the fifth and fourth centuries.

\section{INTRODUCTION}

Greek authors often refer to earlier music. ${ }^{1}$ Sometimes these details are of first importance for the modern historiography of ancient

${ }^{1}$ Editions and translations of classical authors may be found by consulting the article for each in The Oxford Classical Dictionary ${ }^{3}$. Journal 
Greek music. Uniquely valuable, for instance, is Herodotus' allusion to an Argive musical efflorescence in the late sixth century, ${ }^{2}$ nowhere else explicitly attested (3.131-2). In other cases we learn less about real musical history than an author's own biases and predilections. Thus Plato describes Egypt as a never-neverland where no innovation was ever permitted in music; it is hard to know whether Plato fabricated this statement out of nothing to support his conservative and ideal society, or is drawing, towards the same end, upon a more widely held impression-obviously superficial —of a foreign, distant culture (Laws 656e-657f). The frequent lament by fifth- and fourth-century authors about the "demise of music," due to the rise of a more vulgar, exhibitionist art, clearly reflects some real historical development; but its obviously elite bias shows that we are getting only one side of the story (Franklin in press-d). These cases, and many others that could be cited, attest a continuous interest in the musical past. They are also enough to show, as one would anyway expect, that "ancient music" might take on a range of appearances, depending on the observer, and on the material observed.

But "historiography" implies something more systematic-a "scientific" undertaking in the literal sense of "making knowledge" $($ scientia + facere $)$ through a sustained and purposeful engagement

abbreviations follow L'Année philologique. The following abbreviations are used: Aristox. Harm. = Aristoxenus, Harmonic Elements (Stoicheia Harmonica); Ath. = Athenaeus, Deipnosophistae; Bernabé PEG = Poetae Epici Graeci 1 (1988); CID = Corpus des inscriptions de Delphes; Davies EGF = Epicorum Graecorum Fragmenta (1988); Diog. Laert. = Diogenes Laertius; Syll. = W. Dittenberger, Sylloge Inscriptionum Graecarum ${ }^{3}$ (1915-1924); $\mathrm{F}=$ fragment in $\mathrm{FGrH}$; FGrH = F. Jacoby, Fragmente der griechiscen Historiker (1923-); FHG = C. Müller, Fragmenta Historicorum Graecorum (1841-70; fr(r). = fragment(s); Harm., see Aristox. Harm.; Hes. = Hesiod; Hom. = Homer; Il. = Iliad; Od. = Odyssey; [Plut.] De mus. = pseudoPlutarch, De musica; PMG = D. L. Page, Poetae Melici Graeci (1962); PMGF = M. Davies, Poetarum Melicorum Graecorum Fragmenta (1991); s.v. = sub voce ("under the word"); $\mathrm{T}=$ testimonium; Theog. = Theogony. Square brackets ([]) indicate false attributions (generally considered).

${ }^{2}$ All dates are BCE if unqualified. 
with vestiges of the past. By the fourth century the Greeks probably used the word archaiologia in precisely this sense: a reasoned historical account, based upon a variety of sources (not limited to the material record, like the word's narrower modern counterpart). The usage was apparently known to Plato (Hippias major 285d, if authentic), and later writers often apply archaiologia to the lost historical treatises which began to proliferate in the late fifth and early fourth centuries (see e.g. Suda s.v. "Pherekudês"). A number of these dealt with the history of music; all have been lost, but some are represented by large enough fragments to let us form an opinion of the sources available to these scholars, and their methodology. These are the world's first efforts worthy of the name "music archaeology" - the term currently preferred (e.g. Hickmann 1993).

Yet one must first consider a number of passages from earlier Greek poetry which also bear on the musical past. The poets themselves approached the subject in a systematic enough wayand with the express goal of commemoration - that one may reasonably consider their efforts a form of music archaeology avant la lettre. To the extent that their goal was the preservation of musical "knowledge," one may use the term "science" advisedly. This material will often not seem very objective to us: the constructions of poetry, for instance, were sometimes motivated by considerations of genre. But this reservation must confront the Greeks" own early conception of "truth" (aletheia) as "that which is unforgotten," or "unforgettable," as well as the poets' esteemed status as "masters of truth" (Detienne 1996). The later historiographers are not without their own biases, and for the early periods especially are often no more "scientific" than the poetswho were after all their principal "sources" for the remote past, besides being musical sources in their own right. So it becomes arbitrary to distinguish between the two bodies of evidence. They constitute a real continuum, united by a constant concern for earlier music: it is a continuous, self-reflective musical tradition. The oral dimension of Greek "literary" culture was still alive and well even in the literate fourth century. And the musical tradition in the narrower sense-recalling that Greek poetry of the Archaic and Classical periods was almost always sung-remained predominantly aural and oral even after the notation system reached its full maturity in the Hellenistic period (for which see now Hagel 2009). 
Hence scholars could still refer directly to performance traditions that were believed to be-and probably were indeed-archaic styles.

So an understanding of the poets' means of, and goals in, preserving past musical knowledge is a necessary precursor to assessing the historiographical fragments themselves.

\section{The Epic Vision of the Musical Past}

The Greek epic singer was a memory-specialist. He presented his compositional process-a sophisticated oral poetics relying on an extensive system of formulaic diction-as channeling the Muse or Muses (Hom. Il. 1.1, Od. 1.1; Hes. Theog. 1-115, etc.). These goddesses were the embodiment of traditional memory-both mythologically as daughters of Mnemosyne, and etymologically as the power of "Mind" (accepting the derivation of mousa, via * monsa, from the Proto-Indo-European root *men-, "mind"). The Iliad, the Odyssey, and the various poems of the larger epic cycle purported to represent the heroic past, or what we would call the Late Bronze Age-some five centuries or more before the singers themselves. Their portrait of the ancient world is accurate in some ways, in others not. Thus while Homer "remembers" that chariots were a normal feature of warfare, he does not understand how they were used. He knows that there were great palaces, but betrays no awareness of the elaborate scribal bureaucracy which administered them. ${ }^{3}$ In general the singers and their audience seem to have believed that their vision of the past was accurate, to judge from the innumerable approving citations of Homer by later authorities. Even so demanding a critic as Thucydides, while warning that poets will exaggerate or distort for dramatic effect-what modern scholars call "epic distance," the construction of a heroic world as an alternative reality with men stronger, faster, braver, and wiser than our own-balances this with the advice that one should not be unnecessarily skeptical (1.10). Thus, while the historian rationalizes the Trojan War as a political and economic struggle between two leading states which the poets have romantically

${ }^{3}$ For these and other examples, see Snodgrass 1974. 
recast as a tale of rape and revenge, he does not doubt the historicity of the conflict itself.

When considering epic's representation of the musical past, we should expect to find a similar composite of truth and fiction. We are fortunate that these first-attested authors were singermusicians, since this made them naturally interested in musical details. Of course this might lead to an artificial evaluation of the position of music generally, and specifically that of epic as against other forms of music. But one can hardly doubt Homer's general portrait of the epic singer (aoidos) as a normal part of palace life, considering that some epic formulae are of demonstrably Mycenaean antiquity (West 1988, 156-9; Janko 1992, 89-93); that a lyre-singer is represented in the throne-room fresco at Pylos (Lang 1969); and that "two lyrasts" [sic] are now attested among the personnel at Mycenaean Thebes (Aravantinos 1996). Moreover, a sub-repertoire of formulae dealing with the aoidos, his technique, and his social position all attest a long tradition of professional selfpresentation (Franklin 2003). Obviously it was in the singer's professional interests to glorify his own role. Although he was a "public worker" (dêmioergos, Od. 17.383), his stock-in-trade was kleos, fame, a patron's for his own. By "making known (kleiousin) the deeds of gods and men" (Od. 1.338), a singer himself became widely renowned (periklytos, 1.325, 8.367), worthy of being summoned from afar (klêtoi, 17.283-6). Paradigmatic is Hesiod's analogy between patron-singer and Zeus-Apollo (Theog. 93-6 etc.). Superficially this subordinates the singer to a patron's power. But since only Apollo is privy to the "Will of Zeus" (Dios boulê), and it is he from whom singers come (94-5), singer quietly trumps king, making himself indispensible to legitimate government. These ideas, like the conceit of the singer-king (Odysseus, Achilles), which conflates the figures of patron and poet (Franklin in press-b), clearly derive from professional self-interest. Yet these need not be inaccurate reflections of the musical past. On the contrary, the longevity and importance of the epic tradition probably guarantees that the exalted singer is an authentic "document," valid not only in Homer's day, but still more so in the past, while kingship was still dominant_-a changing state of affairs in Homer's time. Consider the poet's assertion that Agamemnon entrusted Clytemnestra to the care of a singer when leaving for Troy (Od. 3.267-72, cf. Scully 1981). This seemingly gratuitous self- 
compliment becomes rather more realistic when seen against Bronze Age archival sources from the Near East. Thus for example the Chief Singer (nargallum) at Old Babylonian Mari was an important official whose duties were not limited to the performance of music, but included sensitive state missions, for instance the negotiation of royal marriages (Ziegler 2007; Franklin 2007b, 32).

A number of allusions to other forms of music-making are found in Homer, Hesiod, and the Homeric Hymns. Their terseness shows that the poets artificially amplified the position of epic, and muffled the broader musical culture. Yet this very fact encourages us in accepting these details as fairly faithful musical data. The more pressing question is whether this muted musical landscape really echoes the earlier centuries, or is merely drawn from Homer's own knowledge of contemporary society. Of course the two positions become simultaneously true when one can confirm that the vignettes represent traditional forms of music. Homer mentions healing incantations $(\mathrm{Od}$. 19.457), which are likely to be very ancient: obviously no examples will be found in the Mycenaean archives, whose Linear B tablets are entirely administrative documents. But comparative evidence shows that such spells had a place in many Indo-European traditions. Mycenaean iconography also shows that there was a continuous tradition of formal lamentation-singing down to Homer's time (Alexiou 2002, 4-23; problematized by Burke 2008). The "Shield of Achilles" contains a vintage scene involving the Linos-song (Il. 18.561-72), a citharodic "lamentation" ([Hes.] fr. 305 Merkelbach-West) with analogues in the ritual laments of the Bronze Age Near East (Franklin 2006, 48), and almost certainly of equal antiquity in the Aegean. The paean-singing that propitiates Apollo's plague (Il. 1.472-4) may well preserve knowledge of a Minoan musical tradition, since Paiawon was a Minoan god whose powers were gradually absorbed by Apollo during the Dark Age (see especially Homeric Hymn to Apollo 475-523). It is unsurprising that the musical mayhem of Cybele's worshippers, described in one relatively late Homeric hymn (14.3-4), finds no place in Homer's own world, since this cult was a relatively late arrival to Greece (see generally Munn 2006). Homer's virtual neglect of the aulos (doublereed-pipe) may or may not be a case of erroneous epic distancethe instrument is attested for the Minoans, but not yet the 
Mycenaeans (West 1992, 82). Yet this may equally be a case of generic exclusion, for epic was a world of lyrists (Franklin in pressa). The mention of choral song and dance at a wedding (Il. 18.4905, cf. [Hes.] Shield, 270-85) probably acknowledges, however tersely, the antiquity and fundamental social importance of traditional choral forms, including the maiden-songs (partheneia) and other musical rites-of-passage which were basic to archaic society (Calame 1977; Kowalzig 2004). These passages, and the citharodic narratives with dance accompaniment among the Phaeacians (Od. 8.250-369), are the only hints of the parallel "lyric" or "melic" tradition which one must posit on the basis of Sappho and Alcaeus-whose ancient "Aeolic" meters are cognate with those of the Rig-Veda (Nagy 1974)—and Stesichorus, whose blend of epic and lyric diction and meter may actually precede the full development of Homer's own dactylic hexameter (Russo 1999). Indeed it may be right to detect an almost hostile relationship between epic and melic, if this may be inferred from the figure of Thamyris (cf. Wilson 2009). Blinded for offending the Muses, Thamyris may represent the purposeful exclusion of a competing sub-tradition, whose desired defeat is symbolized by the loss of "god-uttered song," epic's great prerogative (Il. 2.599-600, cf. 1.328, 8.498; Od. 17.385; Hes. Theog. 31-2; Homeric Hymn to Hermes 442). The Muses make him "forget his lyre-playing" (Il. 2.600), thus negating the "Poetic Memory" (mnêmosynê) which is the epic singer's professional birthright.

Overall, then, I conclude that Homer presents us with what he intends to be an accurate representation of the musical pastand which actually is in many respects. Like other singers in the tradition, he skewed the picture in favor of his own genre, usually through simple emphasis, but occasionally through deliberate sins of omission or distortion. Epic's professional goal, in its commemoration of the "famous deeds of men" (klea andrôn, Il. 9.189 etc.), was essentially a kind of early archaiologia - literally "an account of the past." Because singers were the agents of this, and were concerned to write themselves into the heroic past, Homer and the other epic poets are a surprisingly reliable source of information about earlier music. 


\section{Musical Memory in the Archaic Period (CA. 700- 500)}

Two major developments in the Archaic Period (ca. 700-500) had an important impact on the later historiography of music. First was the rise of pan-Hellenic musical contests, for instance at Delphi, Sparta, Argos, and eventually Athens. Second was the advent of writing in the early eighth century. The two came together in the emergence of official inscriptions, including eventually the recording of festival-victor lists on a year-by-year basis. These documents would provide vital statistics for later "archaeologists," more precise and objective-at least in theory-than material that could be mined from Homer and other epic poets. In practice these sources were not without their own problems, since their earlier stretches might be fabricated from mythology (see further below). Moreover the contest categories were for individual performers, or at most a pair; the festivals included, variously and at various times, lyre-singing (kitharôidia), instrumental lyre music (kitharistikêe), instrumental pipe music (aulêtikêe), and singing to the pipes (aulôidikê). Ensemble music (synaulia: Ath. 617F-618B), though a regular and important feature of Greek musical lifenotably in ritual, civic and military contexts (Huchzermeyer 1931, 48) — was not represented in the contests themselves. This organization, combined with the widespread fame brought by victory, laid the ground for the emergence of individual celebrities. But it also presented later scholars with an artificial picture of earlier musical culture, and so helped determine the shape of their accounts.

Fortunately a second major effect of literacy helped to counteract this sample bias. Writing also enabled the more general emergence of knowable poets, whose creative productions could now be captured in fixed form. Thus later scholars had at their disposal a literary corpus, the individual specimens of which could be studied for distinctive and changing characteristics. From these could be deduced interrelationships between poets, and developing trends could be traced. Often they must have strained to make such connections in the interests of developing a unified history. The fabrication of teacher-student relations between poets exhibiting similar characteristics, or false inferences about a poet's life on the basis of his or her poems, are well-known symptoms of 
Greek biographical scholarship (Lefkowitz 1981). But the fact remains that this was the first period for which Classical scholars had any solid documentary evidence.

The pan-Hellenic festivals, together with the emerging literacy of poet-musicians, will have created an increasing sense of shared musical history. If this was true for the public generally, it must have been still more so for the musicians themselves: they could best appreciate and evaluate a victory in a given contest, or some other public context, and be memorably struck by some decisive innovation or musical milestone. Festivals provided regular occasions for the congregation of Greece's leading musicians, who could observe each other, learn from rivals, and discuss matters of technical and historical import. Symposia and tyrants' courts will have provided another such venue. Under these circumstances it is natural that poets would include professional self-reflections in their poetry (see generally Bowie 2009). One may compare Aristophanes' early comedies, where the central parabasis provided a forum for the poet to discuss his own work and career, and that of his rivals and colleagues (Hubbard 1991). While the bulk of archaic Greek poetry is lost to us, enough remains for us to observe a similar phenomenon. The following examples may serve as a representative catalogue of technical self-reflection, enough to justify the assertion that this dimension of poetic production constituted a mechanism for the purposeful preservation of past musical information:

Terpander (Lesbos, active in Lydia, Sparta, and Delphi, early to mid seventh century), fr. 4 (Gostoli 1990): an exhortation to pass from "four-voiced song" to "new songs on the heptatonic phorminx." (Phorminx is an early word for lyre.) The interpretation of this fragment remains disputed, but may relate to a change in musical styles: see Franklin in press-c.

Alcman (Sparta, late seventh century), [Plut.] De mus. 1133a PMGF: allusion to Polymnestos, a contemporary or slightly earlier aulete (aulos-player) from Colophon.

Hipponax (Ephesus, mid sixth century), [Plut.] De mus. 1133f: mentioned a piece (nomos) called Kradias by Mimnermus, an elegiac poet from Colophon active in the late seventh century. Pratinas (Phlius, active at Athens ca. 500), [Plut.] De mus. 1133e: attributed the invention of the "many-headed piece" 
(polykephalos nomos) to a younger Olympus, thus attesting tradition of reflection on the identity and date of the legendary aulete (see above).

- PMG 708: the famous "hyporcheme" dealing with the proper position of the aulos vis-à-vis the voice. The dating of this fragment is disputed, and some posit a second, younger poet of the same name: see Franklin in press-d, n. 16, with further references.

- [Plut.] De mus. 1134d: mentioned the hyporchemes of Xenodamus.

Pindar (Thebes, active early fifth century), Pythian 12: treated the myth of Athena and the aulos, in a victory ode addressed to the aulete Midas of Akragas (notice the appropriateness of a Phrygian professional name).

- Frr. $70 \mathrm{~b}+81+346$ : dealt with innovations in the history of the dithyramb, and probably the asigmatic odes of Lasus of Hermione (Argolid, late sixth century). See D’Angour 1997; Lavecchia 2000, 30-7; Porter 2007.

- Fr. 125: alluded to Terpander (see above) and his invention of the barbitos (a baritone lyre typical of the symposium) on the model of the harps he had heard at Lydian banquets. Note that Sardis was a major performing center and area of patronage at this time; an Assyrianizing musical movement may have been cultivated there: see Franklin 2007a.

- Fr. 126, perhaps from the same poem as the previous fragment: attributed the invention of sympotic drinking songs (skolia) to Terpander. See further Franklin 2007a, 200.

- Fr. 140b: mentioned a paian by Xenocritos.

- Fr. 157: mentioned Olympus, the (semi-?) legendary, Phrygian founding father of the aulos tradition.

— Fr. 178 (= Strabo 14.1.29, cf. [Plut.] De mus. 1133a): also mentioned Polymnestos (see Alcman above).

- Fr. 265 (= Aelian Varia Historia $9.15=$ Cypria T 1 Davies EGF; T 2 Bernabé PEG): reflected on the fictional tradition that Homer composed the Cypria as a dowry for his daughter's marriage to Stasinus; cf. Franklin in press-b. 
— Fr. 282 (Pausanias 9.30.2; [Plut.] De mus. 1134a): composed a "prelude" (prooimion) which mentioned the innovative Argive aulete Sakadas. See Wallace 2003, 80; Porter 2007, 19; Franklin in press-d.

- [Plut.] De mus. 1136c: In a paian traced the invention of the Lydian harmonia to the wedding of Niobe.

Note how Pindar usually treated such material outside of his epinician odes, which were addressed to individual patrons, and so were largely private affairs despite the public glory an athletic victor enjoyed in his home town. It would be more appropriate for a chorus to sing of music-historical matters in pieces of a more broadly civic character, where they could join the poet in a communal reflection on shared musical experiences of the past; for the chorus, by giving voice to a poet's music, were essential collaborators in the song-act. The exceptions prove the rule: the ode to Midas of Akragas was for victory in a musical competition. The reflection on Terpander came in a skolion addressed to Hieron-a drinking song in which Pindar commented on the history of drinking songs. Note also the wide geographical and chronological spread between the alluding poets and the poets to whom they allude. This is symptomatic of the growing panHellenism of the period (for which see generally Nagy 1990).

It seems reasonable to consider the foregoing material as evidence of a general concern by poets to preserve the memory of their professional past. As with Homer, we see an ongoing impulse towards an archaeology of music. The period's strong oral tradition is certainly sufficient to account for such material. But it is worth considering the possibility that poets sometimes retrieved such material directly from inscriptions at festival sites, which they would be free to consult these documents during their periodic professional congregations. At the very least a victorious poet who was added to an inscription would have had every reason to peruse the earlier reaches of that monument, to glory fully in his own position in the tradition. But it seems likely enough that musicians generally would have been keenly interested in such material. Of course, this scenario would depend on normal literacy among poets. But surely poets loomed large among the early literati, especially by the later Archaic period. This is when, for instance, the impact of literacy on epic diction becomes detectable through 
false archaism and other self-conscious deviation from the tradition's organic linguistic development (Janko 1982).

The archival concerns of festival organizers would thus engender ongoing acts of creative music archaeology, which would in turn feed back into the source material. This would constitute a quite remarkable hybrid of art and scholarship-not unlike the concerns of the later Hellenistic scholar-poets, but within a living musical environment which was gradually passing from orality and literacy.

\section{The First Musical Treatises (CA. 500-400)}

The interplay of oral and written continued throughout the fifth and even the fourth century (Havelock 1963, et al.). Elsewhere I have collected fragments of quasi-technical musical phraseology in Greek epic diction, and showed that some of this language reappears in Aristoxenus and later technical writers; it probably featured in some lost intermediaries of the fifth century, a holdover from the oral tradition. ${ }^{4}$ This period saw the production of a number of prose works on music, which variously emphasized the subject's technical, philosophical, ethical or historical aspects. A catalogue of musicographical works credited to Classical authors may be found in the Appendix. Most of these titles, and even their very existence, cannot be verified. And even if a work did exist, it is often impossible to know, on the basis of its title, whether it would have included historiographical material. The example of Plato suggests that many will have been mainly concerned with ethical or philosophical issues. Yet Aristoxenus' Harmonic Elements show that even a work which was primarily technical could have an historiographical dimension, to the extent that it documented or commented on earlier states of music, or the work of earlier mousikoi. And the fragments of Aristoxenus' lost works show that

4 Thus for example the expression kata melos, "along the scale", which appears first in the Homeric Hymn to Hermes $(53,419,501)$ as integral to the process of tuning, reappears three times in Aristoxenus (Harm. 27-9) in the same context (i.e. in connection with the rule of synecheia, the "continuity" which results from tuning): Franklin 2003, 303-4. 
he scattered historical material quite generally through all of his output, even where the title gives no clear indication of such an interest, for instance his On Melodic Composition or even the Sympotic Miscellanies (see Appendix). A brief survey of some of this early musical activity will serve to illustrate the ongoing, intimate relationship between music-historiography and musicography more generally. ${ }^{5}$

Lasus of Hermione seems to have produced the first work "On Music" (Peri mousikês: Suda s.v. "Lasos"), if that is a true title and not just a generic description. There is no good reason to doubt the existence of this treatise. Lasus is a most likely figure: a progressive "polyphonic" aulete from the Argolid known for his technical innovations, he was later active in the court of Pisistratus, and may have been instrumental in organizing dithyrambic contests for the new Athenian democracy as part of the Cleisthenic reform in 507 (Franklin in press-d). In other words, he was one of the most eminent authorities in a period of rapid musical and social change. Although it is not improbable, we have no hint that Lasus dealt with historical issues. Yet the work raises issues which bear closely upon later historiography, namely the conditions under which musicological thought was propagated during the fifth century. Martianus Capella (9.965) alleges that Lasus divided musical activity into three categories. The terms he gives-bylikon, apergastikon, and exangeltikon or hermêneutikon (roughly "material," "composition," and "performance" or "interpretation")- -have been condemned as Peripatetic or otherwise anachronistic (Privitera 1965, 36-42), thus calling into doubt the work's very existence (Wilamowitz-Möllendorff 1922, 112 n. 2). The idea of a tripartition itself, however, may be genuine, being recast in later terminology (Privitera 1965, 38-9). It would provide an attractive precedent for Aristoxenus' own segregation of barmonikêe ("harmonics") and rbythmikê ("rhythmics") from melopoiia ("melodic composition") and rhythmopoiia ("rhythmic composition"), and in turn from organikêe ("instrumentation": [Plut.] De mus. 1141c-d). At

${ }^{5}$ I have tried to keep the following discussion as straightforward as possible. Unfortunately there is not space to spell out completely every philological point which may be unfamiliar to non-specialists. 
the same time, it is clearly independent of the Aristoxenian taxonomy, the very fact of which is hospitable to its being preAristoxenian. Over four centuries later Theon of Smyrna (59.2260.4) could still discuss aspects of Lasus' work, including perhaps the mathematical division of lyre strings using harmonics-surely how the concordant ratios were first discovered. While Martianus and Theon may be dismissed as dependent upon or distorted by some intermediate source-a Peripatetic biographer like Aristoxenus, Chamaeleon, or Hermippus (Brussich 2000, 16) ${ }^{6}$ - it remains to explain how genuine details of Lasus' work could persist for two centuries and more after his death. Thus, for example, Aristoxenus attributes to Lasus a doctrine that musical notes had "width" (Harm. 7: Privitera 1965, 64-8), and this resonates well with the statement in pseudo-Plutarch that Lasus, "cultivating the polyphônia of the auloi, using more and scattered notes, induced a transformation of music as it had previously been" ([Plut.] De mus. 1141c: see further references in Franklin in press-d, n. 53). The latter passage itself may well derive from one of Aristoxenus' lost historical works. But how did such material come down to Aristoxenus across two centuries?

Harmonics and other musical topics were regular treated by the fifth-century sophists—an environment which remained largely "apodeictic" despite the regular production of literary works. ${ }^{7}$ In this respect the sophists themselves were the heirs of the Archaic poets, both intellectually and by etymology: it was the poets who originally enjoyed the honorific sophos ("wise") and, like the sophists, were often itinerant (Hunter/Rutherford 2009). Hippias, a contemporary of Socrates, is presented by Plato as typical for lecture tours in which he discoursed on rhythms, tunings or modes (harmoniai), letters and syllables (Hippias major 285d, Hippias minor 368d). Aristoxenus mentions various (and undatable) "schools" of barmonikoi ("harmonists") centered around Epigonus of Sicyon, Pythagoras of Zacynthus, and Agenor of Mytiline (Aristox. Harm.

6 That Theon himself did not have direct access to a book by Lasus is shown by the expression "as they say", hôs phasi, 59.3-4.

7 Note the Arcadian festival called Apodeixeis ("Demonstrations"), instituted in the later seventh or early sixth century: [Plut.] De mus. 1134c. 
7, 46). Such groups, and other unnamed harmonikoi, suggest face-toface learning and in-house lectures (see generally Barker 1978; Wallace 1995). Damon of Oa, an associate of Pericles whose musical meddling in the affairs of Athens may have occasioned his eventual ostracism, ${ }^{8}$ is a particularly interesting figure for having had great and enduring influence on the moral and psychological dimensions of musical thought, apparently without leaving any writings of his own (so Wallace 1991). Aristophanes and Plato give some hints of this Damonian induction, including perhaps the latter's appeal to the ethical effects of various harmoniai (Clouds 650-4; Republic 400b, 424c). Damon himself was said to have studied within a school of aulos-teachers whose "family tree" may be traced back for three generations, with a branch connecting to Lasus and Pindar (Wallace 2003, 74 and n. 6). In part this may be a construction of later biographers: the surviving evidence shows that a determined scholar, for instance Aristoxenus in his On AulosPlayers (fr. 100), could have devised an extensive "reconstruction" of the aulos tradition. I present a hypothetical, maximal scenario in fig. 1, which at the very least illustrates clearly the various phases of the "aulos revolution," and the real geographical trends of the Archaic and early Classical periods (see further Franklin in press-d). Whatever the truth of individual biographical connections, one has the clear impression of a vibrant musical scene-exploding in the

${ }^{8}$ It is possible that this was somehow due to his role in the cultural program of Pericles (Wallace 2004), perhaps especially in connection with the new Odeion. What has never been discussed, to the best of my knowledge, is the probable victorious performance by the controversial Phrynis at the inaugural contests (scholion to Aristophanes Clouds $971=$ Ister FGrH 334 F 56; cf. West (1992), 348, 360 n.15), for which musical "rules" were set by Pericles (Plut. Pericles 13.11). Probably relevant to this puzzle is the curious mid-fourth century vase from Paestum which represents Phrynis apparently under some form of arrest by a certain "Pyronides" (Trendall 1987, 2/19). This figure, probably modeled on the historical Myronides and acting as a kind of ghost of the moral past (à la Right Argument in the Clouds), seems to have featured in the Demes of Eupolis (which may in fact be illustrated by the vase). For problems of the Odeion's history and purpose, see recently Miller 1997. 
Argolid, and migrating to Athens-in which music was cultivated side-by-side with musical thought.

An offhand detail in Theophrastus shows that semi-public lectures by harmonikoi were still a familiar occurrence in the later fourth century (Characters 5.10). Aristoxenus refers to such lectures of his own (Harm. 31). Yet pure oral tradition cannot explain all the facts. The catalogue in the Appendix is enough to show that musical writings were not uncommon by the later fifth century, even if we cannot verify all of the attributions made by later bibliographers like Diogenes Laertius. While a work by Simmias may well be a phantom-deriving from Plato's portrait of him discoursing on harmony in the Phaedo-the impressive output attributed to Democritus can hardly be dismissed altogether (see below). The considerable geographical and chronological spread between the various figures and schools just mentioned, combined with Aristoxenus' explicit reference to earlier "diagrams" (diagrammata, Harm. 6, 12, 36), shows that, whatever their internal pedagogical methods, most of these groups must have generated written accounts which were in general circulation among specialists. And if Damon himself wrote nothing, his disciples evidently did. Aristides Quintilianus, writing in perhaps the third century CE (Mathiesen 1999, 521-4) reproduces a number of irregular scales (harmonial) which, he avers, were those known to Plato in the famous musical discussions of the Republic. These are almost certainly to be connected with "the followers of Damon" (boi peri Damona) and "the harmoniai handed down by him" which he mentions elsewhere (2.14: see Barker 1982; West 1992, 174-5 and n. 47). These "scales," which are evidently auletic (Franklin 2005, 26 and n. 50) are certainly "ancient"- though note that, in the grand view of Greek musical history, the fifth century was quite modernist. A. Barker has recently argued that Aristides Quintilianus retrieved these harmoniai from an Aristoxenian work (though he now questions Damon as their source: Barker 2007). This would fit perfectly with S. Hagel's demonstration that Aristoxenus had these very tunings in mind when criticizing an unnamed group of predecessors for their abortive attempt to develop a system of tonoi, "keys" (Hagel 2000, 165 and following). Moreover, Damon's theories of musical ethos (if they are indeed his: Anderson 1966) are a subject of attack in the Hibeh Papyrus on music, composed not before the early fourth century. The attribution of this text to 
the early fourth-century sophist Alcidamas (Brancacci 1988) is, I believe, considerably less plausible than the case for Aristoxenian influence. The principal evidence for the latter position-which no one has yet argued in full-comes from Aristoxenus' allusion to the contents of a series of his own lectures, mentioned above (Harm. 31), and evidently abstracted by pseudo-Plutarch (De mus. 1142b-44e).

None of this provides a definitive proof of an On Music by Lasus, nor any other alleged treatise for which he have only a putative title. What is certain is that, through a combination of oral and written transmission, most or all of the main musicological developments of the fifth century were still available for study by historians even in the late fourth century.

\section{Hellanicus OF LesBos}

So far as our evidence goes, the first musical historiography, in a stricter sense, was produced near the end of the fifth century. Two figures seem to share the glory, Hellanicus of Lesbos and Glaucus of Rhegium, pioneers in their use of sources, combining data from Archaic inscriptions from festival sites (see above), local oral and mythological traditions, and material from the poets. These were also, apparently, the first works to present continuous historical narratives focused on music. Both Hellanicus and Glaucus appear to have presented universal histories of the art down to their own day.

Hellanicus was also a pioneer in the development of chronography. ${ }^{9}$ Often considered the first of the Atthidographers-antiquarians who mined the local history of Attica and Athens, like the later Philochorus-Hellanicus' scope was actually much broader. He coordinated regional inscriptions - the priestesslist from the temple of Hera at Argos, the Eponymous-Archon list of Athens, and perhaps the list of Spartan ephors (see Thucydides 2.2.1, 4.133.2-3) — to develop an historical framework within which to present his wide-ranging researches into mythology,

9 For a recent survey of Hellanicus, with a survey of previous literature, see Möller 2001. 
ethnography, genealogy, geography, and of course more recent historical events. These researches could then be used by other historians as a timeframe for their own works (for the Sicyonian inscription and the Parian Marble, see below). Hellanicus traced "history" deep into the legendary past-the Argive Priestesses included events going back at least three generations before the Trojan War (FGrH 4 F 79b), while the Atthis began with the primeval Attic king Ogyges (323 F 10). Philochorus would later criticize him for fabricating continuous genealogical sequences (FGrH 328 F 92, cf. Hellanicus FGrH 4 T 18, 24). Nevertheless Hellanicus' fragments are a treasury of obscure and precious information.

Of musical relevance was some discussion of the Homeridai, the Chian singers' guild which alleged descent from Homer himself (4 F 20, from the Atlantis). In the Barbarian Customs (Barbarika nomima) he recounted a version of Pythagoras' life, including a journey to Thrace where the mystic preached a doctrine of immortality (4 F 73). It is not impossible that Hellanicus touched upon the harmonic ratios or other musical matters here. But his most important work for the present discussion was the Carnean Victors (boi Karneonikai, FGrH 4 F 85-86), apparently an exegetical treatment of official Spartan inscriptions going back to the festival's organization in $676 .{ }^{10} \mathrm{In}$ fact it is not certain how much of this epigraphic material was genuine. That is, was Terpander's inaugural victory ([Plut. De mus. $1132 \mathrm{e}=$ Glaucus fr. 2 FHG: see below) indeed inscribed on the spot, at the time, and was this practice consistently kept up during the following years? Or were these early stages later constructed on the basis of oral tradition and other considerations? The work is represented by only three certain fragments, but this is enough for profitable speculation in light of what other fragments tell us of the historian's methods and interests. Hellanicus told how "Terpander first of all men won the Carneia" (Athenaeus 625E $=4 \mathrm{~F} 85 \mathrm{a}$ ). While this is clearly no more

10 Actually this was probably a reorganization intended to promote a pre-existing festival for a more pan-Hellenic audience, since the Carneia was celebrated in a number of other Dorian areas, and so was probably an ancestral institution: Burkert 1985, $234 \mathrm{ff}$. 
information than an inscription itself would have yielded, Clement of Alexandria adds that Hellanicus dated Terpander to the time of Midas of Phrygia (85b). Since Midas fell to the Cimmerians some twenty-five years before the first Carneia, some scholars interpret this to mean that Hellanicus did not give-nor find, presumablyan exact date for Terpander (cf. Jacoby 1912, 143; Möller 2001, 245). But this does not necessarily follow. Athenaeus may simply have relayed the general chronological point without giving its chronological underpinning. That he goes on to cite Sosibius for the Carneia's founding date (twenty-sixth Olympiad, 676-3) does not prove that Hellanicus himself did not give the date, since Athenaeus may not have had direct access to Hellanicus' work. The mention of Midas may indicate rather that the historian expanded upon the spare epigraphic evidence, introducing further biographical material, perhaps expanding the inscription's chronology with reference to his own broader researches. That Hellanicus ranged beyond the immediate Spartan performance context is confirmed by $4 \mathrm{~F} 86$ (scholion to Aristophanes Birds 1403), from which we learn that he attributed the invention of the dithyramb (kyklioi choroi) not to Lasus but to Arion of Methymna, Terpander's countryman. This may be confidently connected with a number of other sources that locate Arion's dithyrambic activity at the court of Periander in Corinth (see Franklin in press-d). This fragment shows that the Camean Victors was no mere catalogue, but a more universal history like Hellanicus' other works (Möller 2001, 246). He evidently used the victor list as a window onto the wider world of Greek music in the Archaic period. He must have given special attention to the early Lesbian citharodes, motivated both by pride in his native land, and because these musicians reigned supreme at the Carneia for many generations. The magic of this movement lingered on in the proverbial expression "after the Lesbian singer," an early version of which already appears in a fragment of Sappho (fr. 106 Voigt)—contemporary with the events Hellanicus related. ${ }^{11}$

11 Sappho fr. 106 (Voigt); cf. inter alios Cratinus fr. 263 Kassel-Austin; Aristotle fr. 545 Rose ("Aristotle says in the Constitution of Sparta that the expression "After the Lesbian singer" signified Terpander; and they say 
Given this inevitable Lesbian focus, it is tempting to trace several further testimonies about the professional citharodes of early Lesbos-Terpander, Arion, and the more obscure Kepion and Periclitus-back to Hellanicus. ${ }^{12}$ These seem worth arguing here, and may serve as an example of the complexities of reconstructing lost historiography.

M. L. West has already suggested $(1992,330)$ that the following passage in pseudo-Plutarch comes from the Carnean Victors:

They say that Periclitus was the last citharode of Lesbian birth to win the Carneia in Sparta. And when he died the continuous winning-streak of the citharodic dynasty on Lesbos met its end ([Plut.] De mus. 1133d).

If West is right-Hellanicus is not cited in the text, but pseudo-Plutarch could be drawing on an intermediary source, or simply have failed to mention him-one may also readily add the immediately preceding material, which concerns the enigmatic expression "Asiatic kithara." Pseudo-Plutarch states that the "kithara was called Asiatic because of its use by the Lesbian citharodes, whose homes face towards Asia." A fragment of Duris, sometime tyrant of Samos in the later fourth or early third century, is closely related, but not simply derived from it: they probably share a common source, which may be Aristotle. ${ }^{13}$ The expression

that afterwards, in his honor, his inheritors would be called first [to perform], and then any other Lesbian who was on hand, and then the rest"); Plutarch Moralia 558a; Zenobius 5.9 (1.118 Leutsch/Schneidewin).

${ }^{12}$ Recall, however, the figure of Theodorus who is called an authority on Terpander and later poets: see Appendix.

13 [Plut.] De mus. 1132d, 1133c; Duris FGrH 76 F 81. Weil/Reinach 1900, 29 and Jacoby FGrH ad loc. favored Heraclides of Pontus as the common source. The sequence of quoted material in pseudo-Plutarch offers no decisive support for either party. The Duris fragment involves a textual issue. The reading of the MSS (Dourin ... Aristoteles) cannot stand, since Duris (ca. 340-260) was significantly younger than Aristotle. Hullemann proposed an inversion to Douris . . Aristotelên: see Jacoby's apparatus in FGrH, but note also Müller's attractive solution in FHG. 
"Asiatic kithara" must indeed be quite old: "Asia" derives from Ašsuwa, the ancient Anatolian name for the region later known as Lydia (e.g. Talamo 1979, 99-107); its sense was then extended, through Lydian imperialism, and eventually applied by the first geographers and historiographers in the late sixth and fifth centuries (e.g. Hecataeus, a model for Herodotus) to the entire continent east of Greece (compare e.g. Herodotus 1.15 and 4.45 with 2.16, and see Mazzarino 1947, 52-71). Several later sources, scholiastic and lexicographical, record this original force of "Asia," and sometimes adduce it specifically to elucidate "Asiatic kithara." 14 The musical connection between Lesbos and an "Asiatic" lyre finds a ready explanation in the vibrant Greco-Lydian musical movement of the seventh century, centered on Sardis, which according to Herodotus and other sources drew the intelligentsia from all over Greece (Franklin 2007a). The Lesbian poets in particular were intimately involved due to their proximity. The "Asiatic kithara" might therefore designate a new kind of lyre deriving from this milieu. Some would see it as an early name for the barbitos, whose invention Pindar attributes to Terpander and his activity at Lydian banquets (see above; cf. Barker 1984-1989, 1.211 n. 45). A more likely correlation, I feel, is another assertion found in pseudoPlutarch-that "the form (schêma) of the kithara was first established by Kepion, the student of Terpander" ([Plut.] De mus. 1133 c; cf. West 1992, 53, 329, 330 n. 8). Kepion is an obscure enough figure to inspire some confidence in this construction. The report may be related to an historical transition, observable in vase paintings of the mid- to late-seventh century, from ancient roundbased lyres which had survived from the Bronze Age, to the elaborate, flat-based concert instruments so familiar from Classical representations. This shape resonates much more clearly than the barbitos with the morphology of Anatolian lyres, an ancient tradition going back to the Hittite period (a famous early example is the Inandik vase, and zinar is abundantly attested in Hittite texts). The

${ }^{14}$ Note especially a scholion to Apollonius of Rhodes 2.777-9: "The kithara is called 'Asiatic' since it was first invented in Lydia" (bê kithara Asia<tis? > legetai epei en Lydiai prôton heurethê; cf. Etymologicum Magnum s.v. "Asiatis"; Hesychius s.v. "Asias." 
Anatolian representations (with a few Hellenizing exceptions in the early Archaic period) are always flat based. ${ }^{15}$

In any case, "Asiatic kithara" is a genuinely early linguistic artifact, and it is an attractive guess that Hellanicus offered some explanation of it in connection with the Lesbian school, and perhaps specifically Kepion. If the Carnean Victors may be dated early enough-there is no reason it could not have been available as early as $438^{16}$ - it may account for a small flurry of interest in the expression among poets of the later fifth century, including Euripides, Aristophanes, and perhaps Timotheus, the controversial modernist kithara-singer. I shall explore this problem in detail elsewhere (Franklin in progress). Here I would note only the attractive possibility that Hellanicus' work, as it was made available, influenced the poets of Athens, where he must have worked for years on his Atthis. ${ }^{17}$ This would provide a very interesting case of music-archaeological material passing from inscription to history, and then feeding back into the music stream.

15 Herodotus refers to Lydian lyres at 1.155. For an illustrated catalogue of Anatolian instruments, see Schuol 2004, esp. figs. 28, 39, 42, 43, 45. Note, however, that these lyres typical have asymmetrical arms, contrasting with Greek models. I suggest that we are dealing with a hybridized form, appropriate to the Greco-Lydian movement itself. Hence the symmetry of traditional Aegean lyres persisted as the overall body shape was strongly Lydianized.

16 Hellanicus was an older contemporary of Herodotus, and closely coeval with Euripides: Suda s.v. "Hellanikos"; Aulus Gellius Attic Nights 15.23; Vita Euripidis 2.5; Lucian Macrobii 22). See also next note for Hardie's suggestion about Euripides' use of mousopolos, which could imply publication of the Carnean Victors by 438.

17 A. Hardie has suggested a parallel in Euripides' use of mousopolos in the Alcestis (438 BCE), where the context is again the Carneia. The word was of course used by Sappho of the members of her "circle." Hardie speculates that "Sappho adapted a local citharoedic/guildic coinage to her circumstances, and that Hellanicus' work on Terpander (Carnean Victors) prompted its re-use at Athens" (communication, 2004). Another case involving Euripides may be Hellanicus FGrH 323 F 6. 
At the very least it is clear that Hellanicus, in composing his Carnean Victors, used local oral traditions, drawn from Lesbos, Sparta, and perhaps elsewhere, to flesh out the bare data of the official festival inscriptions, and developed a broader cultural history of music in various geopolitical theatres. It is quite remarkable that the historian chose to produce a second, versified version of the work, presumably in epic hexameters (metrical version: FGrH 4 F 85a, cf. 152b aeidei (Tzetzes); Suda. s.v. "Hellanikos"). There is no need to suppose that this was a later, Hellenistic adaptation: strong contemporary parallels are Critias' metrical account of political constitutions (emmetroi politeiai), and other sophistic works in verse (Jacoby 1912, 143; cf. Pearson 1939, 232). The metrical Carnean Victors constitutes a fascinating transition from the proto-archaeological material of the early poets to the mature prose historiography of the fourth century (see below). It was an epic song about ancient singing.

\section{GLAUCUS OF RHEGIUM}

Glaucus of Rhegium seems to have produced his On the Ancient Poets and Musicians (Peri tôn archaiôn poiêton te kai mousikoi, fr. 2 FHG) around the end of the fifth century, or early fourth. It is worth noting immediately that he must have had to travel abroad from Italy to execute this work. Only seven fragments survive. But three of these (2-4) are extensive enough-excerpted by pseudoPlutarch for the De musica - to give us an idea of Glaucus' methods and sources. Unfortunately the exact boundaries of these fragments are not always clear. Fragment 2 may serve as an example:

Terpander seems to have distinguished himself in the art of singing to the kithara. For he is recorded (anagegraptai nenikêkês) as having won the Pythian contest four times straight. Regarding his era, he is very ancient. At least, Glaucus of Italy, in a certain book-the On the Ancient Poets and Musiciansindicates that he was older than Archilochus. For he says that Terpander came second after those who first composed aulossongs.

From this we learn, at the very least, that Glaucus concerned himself with the relative chronology of musicians, and viewed the aulos and kithara as parallel sub-traditions with unique if interacting histories. But it does seem reasonably certain, as most believe, that 
the assertion of Terpander's four successive victories also comes from Glaucus, being in fact the justification for the dating he proposes. Unfortunately anagegraptai, "it is recorded" is somewhat ambiguous. The verb may imply an actual inscription, like the Sicyonian anagraphê which pseudo-Plutarch mentions as a source for Heraclides of Pontus ([Plut.] De mus. 1132a = Heraclides Ponticus fr. 157 Wehrli: see further below). But this primary meaning engendered the secondary sense of a literary "record" or "register," clearly required elsewhere in pseudo-Plutarch (1133a, hoi anagegraphotes), who indeed refers to Glaucus' book elsewhere as hê Glaukou anagraphê (1133f). Still, the two meanings are naturally linked by the practice of building literary accounts on epigraphic evidence. And the detail of "four in a row" (tetrakis hexês) does seem to evoke, ultimately, an actual lapidary list. There is a similar reference later to the three straight Delphic victories of Sacadas (1134a), which perhaps also comes from Glaucus; Pausanias gives exact and probably correct dates for these victories (10.7.4-5). ${ }^{18}$ The work of Hellanicus shows that there would be nothing implausible in consulting such a source; indeed the Carnean Victors probably made this de rigueur. So one may reasonably see Glaucus as consciously emulating Hellanicus, addressing himself to the Delphic material as his predecessor had the Spartan. If this is right, we have important confirmation that there existed a Delphic victors list before Aristotle and Callisthenes addressed themselves to the subject (see below).

Pseudo-Plutarch follows this passage with a brief citation from Alexander Polyhistor (first century BCE). It is not clear if what then follows is still by Alexander (so Jacoby, FGrH 273 F 77), or has tacitly reverted to Glaucus (Barker 1984-1989, 1.210 n. 33). The chronological relationship between Terpander and Archilochus does eventually recur in the sequel. But it is not perfectly safe to assume that all the intervening information comes from Glaucus. I am inclined to believe that pseudo-Plutarch

${ }^{18}$ Note too that the Delphic inscription which thanked Aristotle and Callisthenes for their work on the Pythian victors-list also contains the same perfect passive participle, here nen]|ikêko[f]ôn: Syll. 3 I, 275; CID IV.10: see further below. 
interwove his source material more thoroughly-and more cunningly - than is often assumed. It is sobering to consider that, as argued above, he probably cited material from Hellanicus without ever naming this important pioneer (again, the material may have come to him indirectly). At any rate, it will be best to limit the present discussion to what may be quite certainly attributed to Glaucus.

Fragment 3 (1133f) shows that Glaucus dealt with traditional repertoire: pseudo-Plutarch cites his attribution to Olympus of the so-called "Chariot Piece" (harmatios nomos). The early "nomes" (Grieser 1937) seem to have been semi-structured modal entities of some sort, performed in a variety of contexts including rituals (in the later fifth century nomos came to be applied to virtuosic solo works). It is not clear whether Glaucus made this "authorial" connection himself, or was merely reporting popular belief. I suspect the latter. Many nome-names are attested in a variety of later sources, including Pseudo-Plutarch, Athenaeus, and the lexicographers. There must still have been traditional repertoire from the Archaic period (and probably earlier) which could be heard and studied by the Classical historians. Aristoxenus discussed traditional aulos music which, he tells us, was attributed to Olympus by "the musicians" (boi mousikoi, fr. 83 Wehrli: Winnington-Ingram 1928; Hagel 2006). While mousikoi sometimes refers to what we would call musicologists-Aristoxenus himself was later known as bo mousikos - the word's more basic sense was simply "musicians" (as in Heracl. Pont. fr. 157 Wehrli $=$ FGrH 124 T 23). And when Plato declares that one could go and hear the music of Olympus, he clearly envisages a living tradition (Symposium 215c; Minos 318b [authenticity doubtful]). At the same time, A. Barker (1984-1989, 1.249-55) has shown that our sources give a misleadingly systematic impression of these early "nomes": many of the names must have been contrived later to account for details of early and otherwise obscure poetic texts-details of both form (rhythm and meter, register or other harmonic and tonal features) and content (self-reflective phrases which could be abstracted as proper titles).

Actually, one may probably suppose that such retroactive analysis was itself an ancient and ongoing feature of the musical tradition, as older repertoire gradually became disconnected from its origins and reworked and re-imagined by successive generations. 
In the remainder of fragment 3 it is hard to discriminate between the fine shades of these processes:

Stesichorus of Himera imitated neither Orpheus nor Terpander not Archilochus nor Thaletas, but Olympus, using his Harmatios nomos and "the dactylic species of rhythm" (trans. Barker), which they say (phasi) comes from the Ortbios nomos.

Glaucus may have been responsible for all, some, or none of these constructions. How is one to evaluate, for instance, the force of "they say" (phasi): does this indicate pseudo-Plutarch's own awareness of further written authorities besides Glaucus? Does it reproduce Glaucus' own appeal to musicians' tradition? Or to earlier historiography (and if so, what?).

What is reasonably certain is that Glaucus gave some stylistic analysis of every figure he treated-recall his book's title-and connected them all into a continuous historical sequence. He apparently began from some "first inventor" (prôtos heuretês: Kleingünther 1933) for each instrument or art-Orpheus and Olympus feature as fountainheads for the kithara and aulos traditions respectively_and traced its development through successive ages down to his own time (for the Cypria, Empedocles and Democritus, see below). His treatment of mythological musicians is further seen in fragment 1 , which attests a discussion of Musaeus. A genuine belief in such founding-fathers was clearly already part of the living tradition, as we have seen for Olympus. Glaucus must then have digested every famous name, and perhaps some minor ones known only or mostly to musicians. A notable innovator was typically presented as combining qualities from two predecessors. This procedure is well illustrated by the longer fragment 4, also from pseudo-Plutarch, which deals with Thaletas, the Cretan musician who is said to have executed musical catharses at Sparta-a well-attested aspect of Archaic kithara music (Franklin 2002, 16). Again Archilochus is invoked as a chronological pointof-reference, but this time there is a stylistic consequence: Thaletas emulated his melodies or scales (melê), but on a grander scale, and introduced the "Cretic rhythm" (Krêtikon rhythmon) which (Glaucus asserts) was alien to earlier citharodic tradition-represented here by Orpheus and Terpander-originating rather in the aulos tradition of Olympus (tês Olympon aulêseôs). Some suspect that Thaletas' connection here with Cretic rhythm may be due to no 
more than his own Cretan origin (cf. Ephorus FGrH 7 F 149 with Barker 1984-1989, 1.215 n. 75). Of course this may be a case of chicken and egg: as a Cretan he may well have used Cretic rhythm (if such rhythm was indeed native to Crete as the name implies). And the obvious Cretan connection makes it quite striking that Glaucus would derive this aspect of Thaletas' work from Olympus, who was believed to be not from Crete but Phrygia! And yet there is remarkable external evidence that here Glaucus was drawing on the living musical tradition. This is shown by the Cretic rhythm used by Athenaeus in his paian, inscribed at Delphi in the early second century BCE (Pöhlmann/West 2001, no. 20). The opening sections of this piece use precisely the scalar material which Aristoxenus, more than a century earlier, had attributed to Olympus on the basis of what he learned from "the musicians" (boi mousikoi: see above). The Delphic hymn's companion piece, the paian of Limenius, also stands in this tonal tradition (Furley/Bremer 2001, 130-1), and a Delphic inscription of 97 BCE refers to a performance of "the ancestral paian" (patrios paian, Fantuzzi in press, 194). Finally one may note that a recently discovered inscription from Hellenistic Mylasa that Cretan ambassadors performed songs which they believed to be by Thaletas (Chaniotis 1988).

So Glaucus did not invent everything from nothing. His historical constructions were built, as far as possible, on "real" source material. I would assert that, as often as not, Glaucus was merely recording what he had heard from musicians, some version of their shared history-which was itself, no doubt, somewhat multiform. Mythological figures like Orpheus and Musaeus are obviously problematic: an increasing number of forgeries were foisted on their names in the sixth and fifth centuries (West 1983, 353-67), and even simple musicians must have found it irresistibly attractive to see themselves standing in some grand and sacred tradition. And yet in one sense they really were! Even when one may well doubt the precise historicity of these received developments, the overall fiction constitutes a fair approximation of the processes by which music does indeed evolve under the appropriate circumstances.

Glaucus evidently gave some attention to literary discussion too, if fr. 6a is correctly assigned: a scholion to Euripides' Hecuba cites a Glaucus for an alternative version of the Trojan Queen's 
death, found in the Cypria. It is interesting that the scholiast does not cite the Cypria directly: this episode, occurring after the action covered in the Iliad, belongs to an earlier state of the poem, before its truncation(s) to form part of the Epic Cycle in the narrow sense of the term (Burgess 2002; Franklin in press-b). So the scholiast probably knew this version of the myth only through Glaucus' summary.

Glaucus' treatment of the fifth century is represented by a lost discussion of Empedocles, including at least the visit to the new Athenian colony of Thurii (fr. $6=$ Diog. Laert. 8.51). This inclusion of Empedocles in a musical history is noteworthy. Aristotle would have considered it a stretch to rank him among "the ancient poets and musicians": in the Poetics he asserts that Empedocles was rather a physiologos, sharing nothing with poets but the use of meter (Poet. 1447b18). Aristotle's assessment is not valueless: Empedocles was obliged to break largely with traditional formulaic diction in order to express his novel cosmological concepts. And yet there remains the testimony of Athenaeus (620d) that Empedocles' Purifications (Katharmoi) were in the repertoire of the rhapsode Cleomenes, and so were clearly performed in a traditional musical setting. This datum confirms the judgment of Glaucus, which must be allowed to balance or even trump that of Aristotle. We must broaden our conception of the aoidos beyond the simple epic singer (Franklin 2002, 19).

The final fragment (fr. $5=$ Diog. Laert. 9.38) shows that Glaucus dealt with another pre-Socratic philosopher, Democritus of Abdera, active in the second half of the fifth century. While nothing further can be deduced, it is also worth reflecting on Democritus' inclusion in a work of musical history. Best known for his atomic theory, Democritus wrote prodigiously on many other subjects, and addressed music and poetry from a number of angles (see Appendix). He also wrote on the senses, and advanced a theory of hearing in terms of atomism (fr. 126a, 135). A strong case has been made for believing that, in elaborating a coherent worldview, Democritus treated letters as analogous to atoms, and euphonious poetry as a sort of kosmos-even if he did not himself use the term stoicheia (variously "letters" or "elements": Armstrong 1995; Janko 2000, 173 ff.). A similar argument could be developed for his treatment of "rhythms and harmonia." The comparison of proper sequences of musical tones to the grouping of letters in 
syllables and words appears frequently enough in Peripatetic writings to assume that it was a well-established topos. This doubtless stemmed from the pairing of mousikê and grammata in education. Indeed, Aristoxenus and Archytas both held that grammatikê was properly subordinate to mousikê. ${ }^{19}$ It is of more than passing interest that Aristoxenus named his treatise the "Harmonic Elements" (Harmonika stoicheia). The Greek notation itself is a perfect fusion of the musical and grammatical, with notes designated by letters. An early stage of the system may thus have provided Democritus with an archetype for the analogy of musical notes and letters, a basis for elaborating some musical theory in accord with his atomist program. So it may be that Democritus is ultimately responsible for the Peripatetic topos. One wonders whether Epicurus, who developed Democritus' atomism and was a rough contemporary of Aristoxenus, may also have been attracted to such ideas in his On Music (Peri mousikếs, Diog. Laert. 10.28).

\section{CONCLUSION}

After Glaucus music historiography exploded. As pseudo-Plutarch states, "most of the Platonists and the best of the Peripatetics ... and all the most cultivated experts in the sciences of grammar and harmonics have also given (music) a great deal of attention" (1131f). They were moved to do so, he asserts, by the feeling that the art was in a state of decline, and the desire to preserve knowledge of what it had been like in the good old days. The political and social bias of this perspective, peculiar to Classical Athens with its popular audiences who promoted new demotic forms, has been often discussed (see Franklin in press-d with further references). But, as I hope to have shown, it is likely that at any given point of Greek history people felt nostalgia for older music as it faded from hearing, and cultivated various techniques for remembering it.

19 Pseudo-Aristotle Problems. 19.20; Aristox. Harm. 27, 37, Rhythmica 2.8, fr. 72; Philodemus On Poems 1.94.22-5; ps.-Plut. De mus. 1144a-c; Quintilian Institutio oratoria 1.10.17; Isidorus Etymologiae 3.16.2. Cf. D’Angour 1999; Janko 2000, 173 ff. 
For the Peripatetics, in particular, we possess many fragments and titles (see Appendix). It is beyond the scope of this paper to examine all of these fragments: a representative sample will be found in pseudo-Plutarch's De musica, to which this paper has referred regularly. That work gives a fair impression of what some of the lost historiographical treatises must have been like; a number of studies have been devoted to explicating its sources (Weil/Reinach 1900; Lasserre 1954; Conti Bizzarro 1994; Barker 1984-1989, 1.205-57). The remainder of the Peripatetic fragments are collected in Die Schule des Aristoteles, with Wehrli's commentary (Wehrli 1967-1969). Heraclides and Aristoxenus are of course enormously important figures in the Greek historiography of music, and problems remain in the interpretation of their work. But going through their fragments here would add little that was new from a methodological point of view. The foregoing discussion of Hellanicus and Glaucus, and their antecedents in the living tradition, has already touched upon most of the sources and methods that would be developed by the fourth-century and later writers. I should add here that archaeological evidence is occasionally cited (musical sculpture: [Plut.] De mus. 1136a; Pausanias 9.35.3). Ethnographic analogy too is sometimes invoked, as with the Agathyrsoi of Thrace who are cited to support the idea that Greek laws had once been sung ([Arist.] Problems 19.28).

Finally one should note both the Parian Marble and the Sicyonian Inscription. The former, a chronicle inscribed in 264/3 BCE, is partially extant; it used the Athenian king list as a framework for other events - sometimes political, but with a heavy concentration on milestones in the history of poetry and music (Jacoby 1904 and FGrH 239). The latter was apparently a similar but somewhat older document known to Heraclides of Pontus. Pseudo-Plutarch alludes to his "Collection of Men $<$ Famous $>$ in Music" (or perhaps "Collection of Musical Matters": hê synagôgê tôn en mousikêi < dialampsantôn vel sim.?>). In this, Heraclides asserted that Amphion was the "first-inventor" of kithara-singing, "and he guarantees (pistoutal) this from the inscription (anagraphê) which is preserved at Sicyon, through which he names (di' hês . . onomazę) the priestesses in Argos and the poets and the musicians" (fr. 157 Wehrli = FGrH $124 \mathrm{~T} 23$ ). Evidently this inscription was a sort of universal musical and literary history by some anonymous hand, although conceivably Heraclides composed it himself, as Aristotle 
and Callisthenes had done for the Delphic Victors list (Elenchoi Pythionikôn, for which they received a public thanksgiving at Delphi: Dittenberger Syll. 3 I, 275; CID IV.10). At any rate it must postdate Hellanicus' work on the Argive priestesses, which it uses that for its chronological scheme (Griffin 1982, 159-60).

\section{APPENDIX}

The following list of attested works of music-historical interest does not claim to be exhaustive. Post-Peripatetic works are not given at all, and I have omitted a number of Classical treatises dealing with various older poets which might be considered music historiography, given the musical nature of Archaic poetry. Nor does this list imply belief in the authenticity of all the works given.

\section{Early Classical Musicography}

Lasus of Hermione (late sixth-early fifth century):

On Music (Peri mousikês): Suda s.v. "Lasos"

Democritus of Abdera, Diogenes Laertius (9.47) lists the following works as dealing with "musical matters" (ta mousika):

On Rhythms and Tuning (Peri rbythmôn kai harmoniês)

On Poetry (or On Composition: Peri poiêsios)

On the Beauty of (Epic) Verses: (Peri kallosynês epeôn)

On Good-Sounding and Bad-Sounding Letters (Peri euphônôn kai dysphônôn grammatôn)

On Homer, or On Proper Diction and Vocabulary (Peri Homêrou $\hat{e}$ orthoepeiês kai glôsseôn)

On Singing (Peri aoidês)

On Words (or "Utterances": Peri rhêmatôn)

On Matters of Names / Words (Onomastikôn). Diog. Laert. 9.47.

Damon of Oa, active in Athens, mid to late fifth century. Wallace

1991 has argued that the "lost" works attributed to him were later forgeries. See further below.

Hippias of Elis:

Olympic-Victors (Olympionikai): Fr. 3 D-K = FGrH 6 F 2 = Plut. Num. 1.

Antisthenes (ca._446-366 BCE), Diog. Laert. 6.16-17:

On Theognis (Peri Theognidos)

On Music (Peri mousikês)

On Homer (Peri Homêrou) 
On the Minstrel's Staff (Peri tês rhabdou).

A number of his other works dealt with specific subjects of literature and mythology.

Simon, Diog. Laert. 2.123:

On Music (Peri mousikês).

On Poetry (Peri poiêseôs).

Simmias of Thebes, Diog. Laert. 2.124. Diogenes Laertius credits him with twenty-three dialogues, including two on musical topics:

On Music (Peri mousikês)

On Verses (Peri epeôn)

Damastes, On Poets and Sophists (Peri poiêtôn kai sophistôn): fr. 10a FHG.

Diocles, the father of the second-generation sophist Alcidamas (born ca. 425), is credited with "writing mousika" (Suda s.v. "Alkidamas"), which may be the title of a work: so Radermacher 1951, 132.

For Philolaus and Archytas, see Huffman 1993; Huffman 2005

\section{Date Unkown}

Theodorus, Diog. Laert. 2.104: An authority upon singers of nomoi (traditional modal pieces) beginning from Terpander: hoperi tôn nomopoiôn pepragmateumenos, arxamenos apo Terpandrou.

Euphranor, Pythagorean, Ath. 182c etc.:

Treatise on Auloi (Syggrama peri aulôn [vel sim.])

\section{Peripatetic Musicography}

Aristotle, Diog. Laert. 5.26:

Olympian Victors (Olympionikai)

Pythian Victors (Pythionikai, with Callisthenes), presumably the same as the Examinations of the Pythian Victors (Elenchoi Pythio nikôn).

On Music (<Peri> mousikếs)

(Dramatic) Victories at the (City) Dionysia (Nikai Dionysiakai)

On Tragedies (Peri tragôidiôn)

Dramatic Records (Didaskaliai) 
Pseudo-Aristotle:

Problems (Problêmata): Books 11 and 19 especially contains details relevant for musical history.

Theophrastus, Diog. Laert. 5.47-9:

On Poetry (Peri poiêtikêss)

On Comedy (Peri kômôidias)

On Music (Peri mousikês, three books)

On the Musicians (Peri tôn mousikôn)

Heraclides of Pontus, Diog. Laert. 5.87:

On the Antiquity of Homer and Hesiod (Peri tês Homêrou kai Hêsiodou hêlikias)

On Archilochus and Homer (Peri Archilochou kai Hômêrou)

On issues in Euripides and Sophocles (Peri tôn par' Euripidêi kai Sophoklei)

On Music (Peri mousikês)

Homeric solutions (Lyseôn Homêrikôn)

On the three tragedians (Peri tôn triôn tragôidopoiôn)

On Poetry and the Poets (Peri poiêtikếs kai tôn poiêtôn).

Collection of Men Famous in Music (hê synagôgê tôn en mousikêi $<$ dialampsantôn [vel sim.]?>).

Aristoxenus of Tarentum:

On Music (Peri mousikês): frr. 69-90 Wehrli.

Musical Hearing (Mousikê akroasis).

Praxidamanteia: frr. 91-92

On Melodic Composition (Peri melopoïas): fr. 93. Largely technical, but did it contain material on Olympus and the spondeion?

Fragments 94-102 are drawn variously from:

On Instruments (Peri organôn)

On Auloi (Peri aulôn)

On Aulos-Players (Peri aulêtôn)

On the Boring of Auloi (Peri aulôn trêseôs: fr. 101)

Fragments 103-112:

On Choruses (Peri chorôn)

On Tragic Dancing (Peri tragikềs orchêseôs)

On Tragedians (Peri tragôidopoiôn) frr. 113-116

Life of Telestes (Telestou bios), fr. 117

Sympotic Miscellanies (Symmikta sympotika), frr. 122-7

Notes (Hypomnêmata), frr. 128-139

Dicaearchus frr. 73-89 Wehrli:

On Musical Contests (Peri mousikôn agônôn) 
On Dionysian contests (Peri Dionysiakôn agônôn)

Panathênaikos

Olympiakos

\section{Later Works}

A number of other music-historical works are mentioned by Pseudo-Plutarch, Athenaeus, and other authorities. Some of the surviving musical writers-Nicomachus, Aristides Quintilianus, Boethius, et al.- -also contain historiographical passages of various sorts. For the Parian Marble, see above.

\section{BIBLIOGRAPHY}

Alexiou, M. (2002). The Ritual Lament in Greek Tradition. Lanham, Maryland and Oxford: Rowman \& Littlefield.

Anderson, W. D. (1966). Ethos and Education in Greek Music. Cambridge, Mass.: Harvard University Press.

Aravantinos, V. (1996). "New Archaeological and Archival Discoveries at Mycenaean Thebes." Bulletin of the Institute of Classical Studies 41: 135-136.

Armstrong, D. (1995). "The Impossibility of Metathesis: Philodemus and Lucretius on Form and Content in Poetry." In: Philodemus and poetry: poetic theory and practice in Lucretius, Philodemus, and Horace, ed. Obbink, D. Oxford University Press: 210-232.

Barker, A. (1978). "Hoi Kaloumenoi Harmonikoi: The Predecessors of Aristoxenus." Proceedings of the Cambridge Philological Society 24: 1-21. (1982). "Aristides Quintilianus and Constructions in Early

Music Theory." The Classical Quarterly n. s. 32: 184-197.

— (1984-1989). Greek Musical Writings. Cambridge: Cambridge University Press.

- (2007). The Science of Harmonics in Classical Greece. Cambridge: Cambridge University Press.

Bowie, E. L. (2009). "Wandering poets, archaic style." In: Wandering Poets in Ancient Greek Culture: Travel, Locality and Panhellenism, ed. Hunter, R./Rutherford, I. Cambridge University Press: 105-36.

Brancacci, A. (1988). "Alcidamante e PHibeh 13 'De musica': Musica della retorica e retorica della musica." In: 
Aristoxenica, Menandrea, Fragmenta Philosophica., ed. Brancacci, A./al., e. 61-84.

Brussich, G. F. (2000). Laso di Ermione. Testimonianze e frammenti. Pisa: ETS.

Burgess, J. (2002). "Kyprias, the 'Kypria', and Multiformity." Phoenix 56.3/4 (Autumn 2002): 234-245.

Burke, B. (2008). "Mycenaean Memory and Bronze Age Lament."

In: Lament: studies in the ancient Mediterranean and beyond, ed. Suter, A. Oxford University Press: 70-92.

Burkert, W. (1985). Greek Religion. Cambridge, Mass.: Harvard University Press.

Calame, C. (1977). Les choeurs de jeunes filles en Grèce archaïque. Rome: Edizioni dell'Ateneo.

Chaniotis, A. (1988). "Als die Diplomaten noch tanzten und sangen. Zu zwei Dekreten kretischer Städte in Mylasa." Zeitschrift für Papyrologie und Epigraphik 71: 154-6.

Conti Bizzarro, F., (1994). "Note a Ps.-Plutarch. de musica." Museum Criticum 29: 259-261.

D'Angour, A. (1997). "How the Dithyramb Got its Shape." The Classical Quarterly 47: 331-51. (1999). "Archinus, Eucleides and the Reform of the

Athenian Alphabet." Bulletin of the Institute of Classical Studies 43: 109-130.

Davies, J. (1994). “The Tradition about the First Sacred War.” In:

Greek Historiography, ed. Hornblower, S. Oxford University Press: 193-212.

Detienne, M. (1996). The Masters of Truth in Archaic Greece. New York: Zone Books.

Fantuzzi, M. (in press). "Sung Poetry: The Case of Inscribed

Paeans." In: Companion to Hellenistic Literature, ed. Clauss, J./Cuypers, M. 181-196.

Franklin, J. C. (2002). "Harmony in Greek and Indo-Iranian Cosmology." The Journal of Indo-European Studies 30/1-2: $1-25$.

(2003). "The Language of Musical Technique in Greek

Epic Diction." Gaia. Revue interdisciplinaire sur la Grèce archaïque 7: 295-307. (2005). "Hearing Greek Microtones." In: Ancient Greek

Music in Performance, ed. Hagel, S./Harrauer, C. Verlag 
der Österreichischen Akademie der Wissenschaften: 9_ 50.

Franklin, J. C. (2006). "Lyre Gods of the Bronze Age Musical Koine." Journal of Ancient Near Eastern Religions 6.2: 3970 .

(2007a). "A Feast of Music. The Greco-Lydian Musical Movement on the Assyrian Periphery." In: Hittites, Greeks and Their Neighbors in Ancient Anatolia, ed. Collins, B. J., et al. Oxbow: 193-203. (2007b). "The Global Economy of Music in the Ancient Near East." In: Sounds of Ancient Music, ed. Westenholz, J. G. Keter: 27-37.

(in progress). "The 'Asiatic Kithara': Orpheus, Terpander, and the Carnean Victors of Hellanicus."

(in press-a). "Aulos." In: The Homer Encyclopedia, ed. Finkelberg, M. Blackwell: s.v.

(in press-b). "Greek Epic and Kypriaka: Why 'Cyprus Matters'." In: Yuval. Studies of the Jewish Music Research Centre. Vol. 8: Sounds from the Past: Music in the Ancient Near East and Mediterranean Worlds, ed. Maurey, Y., et al. The Magnes Press / The Hebrew University.

_ (in press-c). "Music." In: The Homer Encyclopedia, ed. Finkelberg, M. Blackwell: s.v.

- (in press-d). "'Song-Benders of Circular Choruses': Dithyramb and the 'Demise of Music'." In: Song Culture and Social Change: The Contexts of Dithyramb, ed. Wilson, P./ Kowalzig, B. Oxford University Press.

Furley, W. D. / Bremer, J. M. (2001). Greek Hymns: Selected Cult Songs from the Archaic to the Hellenistic Period. Tübingen: Mohr Siebeck.

Gostoli, A. (1986). "La figura dell'aedo preomerico nella filologia peripatetica ed ellenistica: Demodoco tra mito e storia." In: Scrivere e recitare, ed. Cerri, G. 103-126.

- (1990). Terpandro: Introduzione, testimonianze, testo critico, traduzione e commento. Rome: Edizioni dell'Ateneo.

Grieser, H. (1937). Nomos: Ein Beitrag zur griechischen Musikgeschichte. Heidelberg: Bilabel.

Griffin, A. (1982). Sikyon. Oxford: Oxford University Press. 
Hagel, S. (2000). Modulation in altgriechischer Musik: Antike Melodien im Licht antiker Musiktheorie. Frankfurt am Main: P. Lang.

Hagel, S. (2006). "The Context of Tunings: Thirds and Septimal Intervals in Ancient Greek Music.” In: Musikarchäologie im Kontext: Archäologische Befunde, historische Zusammenbänge, soziokulturelle Beziebungen. Serie Studien zur Musikarchäologie 5, ed. Hickmann, E., et al. Verlag Marie Leidorf: 281-304.

_ (2009). Ancient Greek Music: A New Technical History. Cambridge: Cambridge University Press.

Havelock, E. A. (1963). Preface to Plato. Cambridge, Mass.: Harvard University Press.

Hickmann, E. (1993). "Musikarchäologie-Metapher und Methode." In: Miscellanea archaeologica Thaddaeo Malinowski, ed. Roznowski, F. Sorus: 177-187.

Homolle, T. (1898). "Inscription de Delphes." Bulletin de correspondance bellénique 22: 260-270.

Hubbard, T. (1991). The Mask of Comedy: Aristophanes and the Intertextual Parabasis. Ithaca: Cornell University Press.

Huchzermeyer, H. (1931). Aulos und Kithara in der griechischen Musik bis zum Ausgang der klassischen Zeit. Emsdetten: Lechte.

Huffman, C. A. (1993). Philolaus of Croton. Cambridge: Cambridge University Press.

(2005). Archytas of Tarentum: Pythagorean, philosopher, and mathematician king. Cambridge: Cambridge University Press.

Hunter, R. / Rutherford, I. (2009). Wandering Poets in Ancient Greek Culture: Travel, Locality and Panhellenism. Cambridge: Cambridge University Press.

Jacoby, F. (1904). Das Marmor Parium. Berlin: Weidmann.

- (1912). "Hellanikos." In: Real-Encyclopädie der classischen Altertumswissenschaft, ed. Pauly, A. F. von/Wissowa, G. Stuttgart: J. B. Metzler: viii/i 104-53.

Janko, R. (1982). Homer, Hesiod and the Hymns. Cambridge: Cambridge University Press. (1992). The Iliad: A Commentary, Volume IV: books 13-16.

Cambridge: Cambridge University Press. 
Janko, R. (2000). Philodemus On Poems. Oxford: Oxford University Press.

Kleingünther, A. (1933). Prôtos heuretês. Leipzig: Dieterich.

Kowalzig, B. (2004). "Changing Choral Worlds: Song-Dance and Society in Athens and Beyond." In: Music and the Muses. The Culture of "Mousikê" in the Classical Athenian City, ed. Murray/Wilson. 39-65.

Lang, M. (1969). The Palace of Nestor at Pylos, II. The Frescoes. Princeton, NJ: Princeton University Press.

Lasserre, F. (1954). Plutarch. De la musique. Olten-Lausanne: Urs Graf Verlag.

Lavecchia, S. (2000). Pindari Dithyramborum Fragmenta. Rome and Pisa: Edizioni dell'Ateneo.

Lefkowitz, M. (1981). The Lives of the Greek Poets. Baltimore, MD: Johns Hopkins University Press.

Mathiesen, T. J. (1999). Apollo's Lyre: Greek Music and Music Theory in Antiquity and the Middle Ages. Lincoln, Neb. and London: University of Nebraska Press.

Mazzarino, S. (1947). Fra Oriente e Occidente; ricerche di storia greca arcaica. Florence: La Nuova Italia.

Miller, M. C. (1997). Athens and Persia in the fifth century B.C.: a study in cultural receptivity. Cambridge: Cambridge University Press.

Möller, A. (2001). "The Beginning of Chronography: Hellanicus' Hiereiai." In: The Historian's Craft in the Age of Herodotus, ed. Luraghi, N. Oxford University Press: 241-262.

Munn, M. (2006). The Mother of the Gods, Athens, and the Tyranny of Asia. A Study of Sovereignty in Ancient Religion. Berkeley: University of California Press.

Nagy, G. (1974). Comparative Studies in Greek and Indic Meter. Cambridge, Mass.: Harvard University Press. (1990). Pindar's Homer: The Lyric Possession of an Epic Past. Baltimore: Johns Hopkins University Press.

Pearson, L. I. C. (1939). Early Ionian Historians. Oxford: Oxford University Press.

Pöhlmann, E. / West, M. L. (2001). Documents of Ancient Greek Music. Oxford Oxford University Press.

Porter, J. (2007). "Lasus of Hermione, Pindar, and the Riddle of S." Classical Quarterly 57.1: 1-21. 
Privitera, G. A. (1965). Laso di Ermione nella cultura ateniese e nella tradizione storiografica. Rome: Edizioni dell'Ateneo.

Russo, J. (1999). "Stesichorus, Homer, and the Forms of Early Greek Epic." In: Euphrosyne: Studies in Ancient Epic and Its Legacy in Honor of D. M. Maronitis, ed. Kazazis, J. N./Rengakos, A. Steiner: 339-348.

Schuol, M. (2004). Hethitische Kultmusik. Eine Untersuchung der Instrumental- und Vokalmusik anhand hethitischer Ritualtexte und von archäologischen Zeugnissen. Rahden: Verlag Marie Leidorf.

Scully, S. (1981). "The Bard as Custodian of Homeric Society: Ody. 3.261-272." Quaderni urbinati di cultura classica 37: 67-83.

Snodgrass, A. M., (1974). "An Historical Homeric Society?" The Journal of Hellenic Studies 94: 114-125.

Talamo, C. (1979). La Lidia arcaica: tradizioni genealogiche ed evoluzione istituzionale. Bologna: Pàtron Editore.

Trendall, A. D. (1987). The Red-Figured V ases of Paestum. Rome: British School at Rome.

Wallace, R. W. (1991). "Damone di Oa ed i suoi successori: un'analisi delle fonti." In: Harmonia Mundi: Musica e Filosofia nell'Antichità, ed. Wallace, R. W./MacLachlan, B. $30-53$.

(1995). "Music Theorists in Fourth-Century Athens." In:

Mousike: Metrica Ritmica e Musica Greca in memoria di Giovanni Comotti, ed. Gentili, G./Perusino, R. 17-40. (2003). "An Early Fifth-Century Athenian Revolution in Aulos Music." Harvard Studies in Classical Philology 101: 73-92.

(2004). "Damon of Oa: A Music Theorist Ostracized?" In: Music and the Muses. The Culture of "Mousikê" in the Classical Athenian City, ed. Murray/Wilson. 249-267.

Wehrli, F. R. (1967-1969) Die Schule des Aristoteles. Texte und Kommentare. Basel: Schwabe.

Weil, H. / Reinach, T. (1900). Plutarque. De la musique. Édition critique et explicative. Paris: E. Leroux.

West, M. L. (1983). The Orphic Poems. Oxford: Oxford University Press.

(1988). "The Rise of Greek Epic." The Journal of Hellenic Studies 108: 151-172. 
West, M. L. (1992). Ancient Greek Music. Oxford: Oxford University Press.

Wilamowitz-Möllendorff, U. v. (1922). Pindaros. Berlin: Weidmann. Wilson, P. (2004). "Athenian Strings." In: Music and the Muses. The Culture of Mousikê in the Classical Athenian City, ed. Murray/Wilson. 269-306.

Wilson, P. (2009). "Thamyris the Thracian: the archetypal wandering poet?" In: Wandering Poets in Ancient Greek Culture: Travel, Locality and Panhellenism, ed. Hunter, R./Rutherford, I. Cambridge University Press: 117-187. Winnington-Ingram, R. P., (1928). "The Spondeian Scale." The Classical Quarterly 22: 83-91.

Ziegler, N. (2007). Les Musiciens et la musique d'après les archives royals de Mari. Paris: Societe pour l'Etude du Proche-Orient Ancien. 


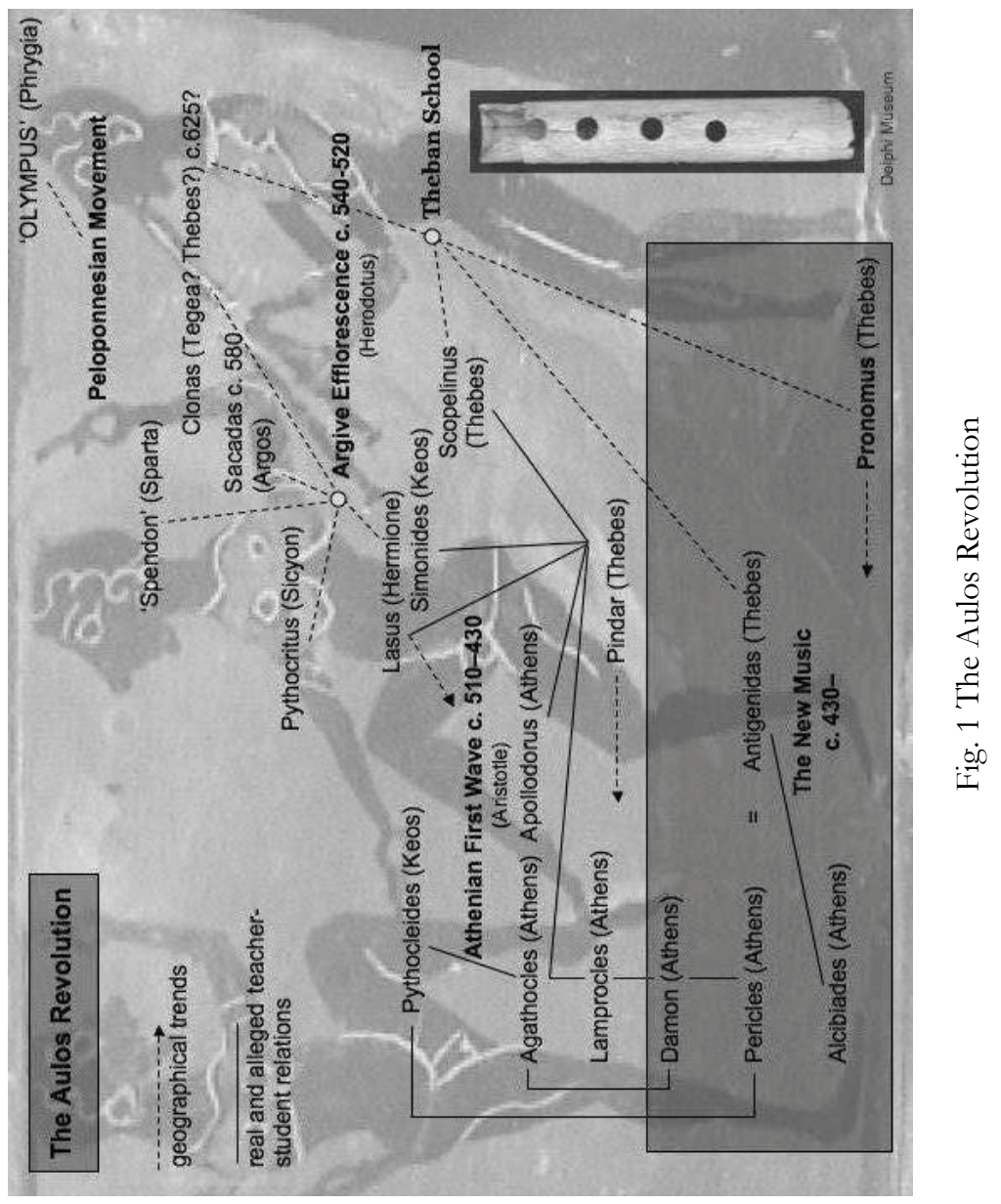





\title{
INTERPRETING NON-EUROPEAN PERCEPTIONS AND REPRESENTATIONS OF EARLY MODERN EUROPEAN MUSIC
}

\author{
DAVID R. M. IRVING
}

\begin{abstract}
This chapter has emerged from the contemplation of various interpretative methods that relate to an ongoing study of the origins, development, and consequences of the globalization of music from circa 1500 to 1815 . It seeks to critique the various forms of non-European perceptions and representations of European musical practices. It briefly outlines and evaluates the range of surviving evidence that serves to demonstrate non-European interest in and engagement with European music during the early modern period, and debates some of the issues surrounding the interpretative filters and methodological approaches employed by musicologists working with these sources today.
\end{abstract}

The nineteenth century rise of comparative musicology, the disciplinary forebear of ethnomusicology, relied largely on the analysis and interpretation of European documentation of musics from around the world. One of the most substantial banks of data from which comparative musicologists drew their evidence consisted of observations that had been made (often unreliably) by explorers, missionaries, diplomats, and traders, from the early modern "Age of Discoveries" onwards. The West/"rest" dichotomy that was devised and upheld through this heavily biased reliance on writings by misinformed European travellers, however, meant that comparison was usually Eurocentric and unidirectional. 
Although there were undoubtedly many reciprocal acts of intercultural inquiry from the sixteenth to the nineteenth centuries-in terms of non-Europeans critiquing European music - there are relatively few records of them. But it behoves us to consider those that do exist, as their very rarity seems to accord them some higher form of value in terms of the global study of early modern intercultural engagement and exchange.

At the outset of this discussion, we must acknowledge that the vast majority of the surviving evidence of non-European observations comes from European travel writing describing the performance of European music in other parts of the world. These performances were usually carried out with the deliberate intention of exciting curiosity and gauging levels of interest in European cultural practices, for the ultimate purposes of embarking on evangelistic projects or opening up a trading relationship. ${ }^{1}$ Numerous accounts of voyages, especially in the eighteenth century, positioned musical performance (which often included dancing) as a central and pivotal act of cross-cultural engagement, as scholars including Vanessa Agnew, Inga Clendinnen, and Ian Woodfield have shown. ${ }^{2}$ A whole mythology has also grown up around the use of music as a type of "honey-trap" in the establishment of Jesuit Reductions in the South American continent. This notion began to be romanticized at the dawn of the nineteenth century, especially with the writings of François-René Chateaubriand in his apologetic Génie du Christianisme (which describes the warlike Guaraní dropping their weapons at the sound of European music, falling tearfully to their knees, and embracing the new religion). ${ }^{3}$ Earlier missionary writings of the seventeenth and eighteenth centuries also drip with hyperbole and exaggeration. The implication is that music became a powerful tool in "seducing" and "reducing" the indigenous population of the Americas, just as

${ }^{1}$ On trade and diplomacy, see Woodfield 1990; on other types of intercultural reciprocity involving instruments, see Irving 2009, especially 392-97.

2 See Agnew 2008, Clendinnen 2005, and Woodfield 1990.

${ }^{3}$ Chateaubriand 1809, 4: 183-84. 
it did those of other parts of the world. ${ }^{4}$ Of course, there is a certain teleology implicit in the idea that non-Europeans would inevitably adopt European cultural trappings, such as music, in a process of transculturation that enabled them to engage with Europeans on mutually familiar terms. But it is a teleology that is easily deconstructed by examining non-European records.

Some Western sources describe non-European reactions to European music performed within Europe itself, and are found within letters, periodicals, and various scholarly publications. Ambassadors and trading delegations to Europe were often entertained at the opera in Paris and London, or shown the theatrical splendours of ecclesiastical ceremonies in Rome and Madrid. We must not neglect to consider the individuals or small groups of captives from the Americas, Africa, Asia, Australia, and the Pacific, who were said to be "captivated" by the arts of Europe. Although many of these people were treated quite well — by the standards of the time - and accorded royal or aristocratic titles and privileges, they were still under the control of their hosts. Then there is the category of slaves, who had their own musical traditions that were vividly documented, but whose reactions to European artforms were often observed in racist terms that pondered upon their capacities to take up arts that were seen as the benchmark of what early modern Europeans considered to be more "advanced" civilizations. ${ }^{5}$

Our first historiographical category is thus the record of nonEuropean encounters with Europe that were staged or contrivedthen documented-by Europeans themselves. Europeans were undoubtedly interested or amused to see reflections or assessments of their own culture offered by these veritable mirrors of alterity. Yet the raw reactions and perceptions of observers were coated with so many layers of prejudice or expectation in their recording and reinterpretation (by Europeans) that we can begin to view these texts as a form of reflexive autoethnography. The non-

${ }^{4}$ For the case of mission music in the Philippines, see Irving 2010, $110-17$.

5 See a discussion of one example of such an observation in Irving 2009, 396-97. 
European voice was exploited as a passive agent in a reinforcement of essentialized European identity, in the face of increasingly diversified cultural interactions that were mediated by global networks. ${ }^{6}$ It becomes evident that the early modern crisis of selfrepresentation in European scholarship arose from the challenges levelled by discoveries of other worlds and other civilizations from 1492 onwards, together with the necessity of repositioning European culture within ontological and epistemological frameworks whose boundaries continued to expand exponentially, and whose inner workings became ever more complex.

The next historigoraphical category comprises the graphic and physical records that non-Europeans made of European music. By these I imply the texts and images produced by literate cultures (such as those in China, India, and Japan), the iconographic representations left by members of oral cultures, and the threedimensional physical objects produced by both (including sculptures and copies of instruments). ${ }^{7}$ All of these records constitute what can be called "materialized symbolic representation." As with texts produced by Europeans, however, we are faced with the question of these sources' cultural "authenticity" and the extent of their reliability as evidence of unbiased evaluations. A line is drawn between non-Europeans who acted according to their own cultural traditions, and those who were subjugated through European colonialism and who were incited to make these representations (for example, those who were resettled to live in religious missions, and whose behavioural practices and aesthetic dispositions were influenced by active and passive processes of transculturation). Another way in which the non-European perception of European music manifested itself was in the performative ramifications of musical transculturation; that is to say, by means of the syncretic and hybrid performance styles and

${ }^{6}$ For a detailed exploration of this point, see Hoyt 2001.

7 For two splendid examples of Indian and Japanese paintings of European instruments see, respectively, Woodfield 1990, 49, and Blussé 2004, 135. 
genres that arose through sustained periods of intercultural engagement, particularly in colonial contexts. ${ }^{8}$

It seems a truism to say that if fruitful cross-cultural dialogue ever truly takes place, it usually results from sufficient periods of experience and exposure to allow the development of empathy on the side of all parties involved. Yet it is clear that long term relationships of perceived mutual alterity very often also reinforce cultural self-definition by all parties. It is therefore in the interest of each faction to emphasize difference. Where commercial, diplomatic, or evangelistic relationships are at stake, reactions to the music of the Other can constitute a powerful and symbolic measure of the potential for success. This is perhaps more critical at the moment of initial encounters, as Agnew has pointed out, or at formalized meetings of the elite from both groups, where the ritualized exchange of performances are seen either as gestures of goodwill or a play of power. ${ }^{9}$ In the early modern period, the most detailed observations of a foreign culture were usually made when the members of the observed culture were situated in their own environment. Thus non-European observations of European musical practices could be considered to be more authoritative and extensive when they were made in Europe.

One of the most noteworthy genres documented by nonEuropean observers was opera, the most glamorous and spectacular performative artform of early modern Europe. Sung music-drama with staging is, of course, by no means exclusively European; countless analogous forms exist throughout the world. But European opera represented one of the most expensive and elaborate types, even before the excesses of the nineteenth century. ${ }^{10}$ Opera became a standard emblem of European culture

${ }^{8}$ For a discussion of this process in the Philippines, see Irving 2010, 99-133.

9 See Agnew 2008, 93.

${ }^{10}$ We should note, incidentally, that the costs of producing operas in Europe were usually defrayed by the patronage of the nobility, who in turn were increasingly reliant on income resulting from the effects of the rise of global capitalism, involving the extraction and exploitation of valuable natural resources from the rest of the world. It is perhaps with a 
that was broadcast to representatives of other civilizations. Envoys from Tahiti, Siam, Turkey, and Persia were all taken to see operas in Paris or London as an exhibition of European visual and sonic arts. Their reactions were carefully noted: for instance, the two Tahitians Aotourou (also known as Putaveri) and Mai (also known as Omai), who travelled to Paris and London respectively, became central figures in the philosophical debates of the time about the aesthetic qualities and virtues of French and Italian opera (and other types of musical expression), because of their reactions to the performances they witnessed. ${ }^{11}$ The Tahitians' arrival in Europe coincided with a local craze for primitivism in the arts, and the idealization of the unfettered "good savage" or natural man, "unspoiled" by civilization. Both of these men were observed to parody operatic styles of singing, and the inference was made that they "naturally" preferred the Italian style of opera over the French.

All such visits by non-Europeans were reported by European writers, but in 1721 the Ottoman ambassador Yirmisekiz Çelebi Mehmed Efendi made his own detailed description of opera. He described it as a dancing spectacle with music in which "stories" were presented.12 (He saw Lully's Thésée and Destouches's Omphale in Paris.) We should note that Ottoman visitors to European capitals were likely to encounter a representational mirror, for turquerie was, of course, all the rage in European opera of the late seventeenth century and especially the eighteenth century, and many noble houses had their own ensembles that were dedicated to playing "Turkish" music. But Turkish visitors were often unimpressed, and at least one ambassador was noted to comment laconically of a "Turkish" band: "That's not Turkish."13 Still, some

twist of irony, then, that we can view the invitations issued to nonEuropeans to attend the opera in European capitals, although the parties involved in these types of exchanges were probably unaware of the extent to which the economies of different parts of the world were becoming increasingly integrated and interdependent.

11 See Irving 2005, 217-22.

12 Göçek 1987, 47-48; Mehmed Efendi and Veinstein 1981, 115-19.

13 See Bowles 2006, 553. 
seem to have appreciated the attempt at mimicry or imitation, or at least to have been flattered by it. In Lyon in September 1721, the son of Mehmed Efendi requested an encore of the Turkish act in a performance of André Campra's L'Europe Galante, so taken did he appear to be with the European representation of Ottoman culture. ${ }^{14}$

Here the present-day musicologist is faced with an even more complex conundrum: how do we interpret our reaction to the early modern Turkish reaction to the early modern European reaction and representation of Turkey? The examination of these multiple dimensions of culture and time involves the employment of many layers of analytical filtration. Yet we must be careful not to lose sight of some of the deeper and more critical issues of intercultural empathy and musical homologies. The solution is to situate these curious records of encounter within a broader interpretative framework provided by due consideration of the processes of early modern globalization. That is, we must think about how interpretation and reinterpretation contributes to the emergence of a global consciousness, in terms of what early modern theorists learnt and observed from reactions to foreign musical stimuli and intercultural comparisons, made from both sides.

As I remarked earlier, a general formula can be applied to our study of early modern intercultural contact, namely that relationships of perceived mutual alterity reinforce cultural self-definition by both parties. Intercultural comparison of musics in the necessarily plural "Age of Discoveries" was of paramount importance to the development of taxonomies of music and the intellectual processes that led eventually to the emergence of comparative musicology, ethnomusicology's forebear, as a serious academic discipline in the late nineteenth century. For far too long, however, this comparison has been unidirectional and Eurocentric. By taking a more nuanced view of the historiography of non-European reactions to European music - with blocks of information provided from both sides - we can begin to construct a better-proportioned picture of intercultural comparison of diverse music cultures in the early modern world.

14 Mehmed Efendi and Veinstein 1981, 208. 


\section{BIBLIOGRAPHY}

Agnew, V. (2008). Enlightenment Orpheus: The Power of Music in Other Worlds. New York: Oxford University Press.

Blussé, L. (2004). "Dutch Settlements and Trading Centres." In: Encounters: The Meeting of Asia and Europe 1500-1800. Ed. A. Jackson and A. Jaffer. London: V\&A Publications.

Bowles, E. A. (2006) "The Impact of Turkish Military Bands on European Court Festivals in the 17th and 18th Centuries." Early Music 34.4: 533-59.

Chateaubriand, F.-R. (1809). Génie du Christianisme, ou beautés de la religion chrétienne. 5th ed. Lyon: Ballanche Père et Fils. 5 vols.

Clendinnen, I. (2005). Dancing with Strangers: The True History of the Meeting of the British First Fleet and the Aboriginal Australians, 1788. Edinburgh: Canongate Books.

Göçek, F. M. (1987). East encounters West: France and the Ottoman Empire in the Eighteenth Century. New York and Oxford: Oxford University Press in cooperation with the Institute of Turkish Studies.

Hoyt, P. A. (2001). "On the Primitives of Music Theory: The Savage and Subconscious as Sources of Analytical Authority." In: Music Theory and Natural Order from the Renaissance to the Early Twentieth Century. Ed. S. Clark and A. Rehding. Cambridge: Cambridge University Press.

Irving, D. R. M. (2005). "The Pacific in the Minds and Music of Enlightenment Europe." Eighteenth-Century Music 2.2: 205-29.

(2009). "Comparative Organography in Early Modern Empires.” Music \& Letters 90.3: 372-98. (2010). Colonial Counterpoint: Music in Early Modern Manila. New York: Oxford University Press.

Mehmed, Y. C.. and G. Veinstein. (1981). Le paradis des infidèles: relation de Yirmisekiz Çelebi Mehmed efendi, ambassadeur ottoman en France sous la régence. Trans. Julien-Claude Galland. Paris: François Maspero.

Woodfield, I. (1990). "The Keyboard Recital in Oriental Diplomacy, 1520-1620." Journal of the Royal Musical Association 115.1: 33-62. 


\title{
From MUSIC ARCHAEOLOGY TO HISTORIOGRAPHY:
}

\author{
ANDEAN MUSIC ARCHAEOLOGY \\ AND MUSICAL INSTRUMENTS, SINGING \\ AND DANCING IN GUAMAN POMA'S \\ NUÉVA CRÓNICA Y BIEN GOBIERNO
}

\author{
ELLEN HICKMANN
}

\begin{abstract}
Felipe Guaman Poma de Ayala was an Indigenous chronicler who wrote the book. Nuéva Crónica y Bien Gobierno (1615/1616) during the first period of the Conquista. It is about the life of the indigenous people and their relationship to the Spanish conquerers. The book has a lot of drawings which are unique. In many of them, musical instruments in the hands of musicians, and dancing are depicted. These depictions of instruments can be compared to archaeologically excavated instruments of earlier times, many of which completely disappeared during the Conquista. Guaman Poma must have known some of these instrument-types. When such historiographical points of view are considered, important questions of methodology in music archaeology are raised.
\end{abstract}

In the Andean region and specifically in its western lowlands, the Sierra, numerous cultures flourished before the Inca established their kingdom, the Tahuantinsuyu, and later the Europeans conquered that part of South America. Little is known about these illiterate cultures. However, relatively rich archaeological treasures, including many musical instruments, bear witness to their former 
existence. Guaman Poma, our author, lived at the beginning of the period during which Europeans taught the Indians to read and write using Latin script. Guaman Poma drew musical instruments and he wrote about music, making his work of great historiographical interest. Before I introduce him and his book to you, I want to give you an overview of the instruments known from archaeological excavations which were used by the people of the early cultures preceding the Inca. The diversity of instrumental types is remarkable. They are dated ca. 500 BC-500 AD; a more precise and detailed dating is generally not yet possible. Some of the instruments are from later cultures (e.g. bells ). Today, preColumbian music instruments are kept in museums of Latin America, North America and Europe. We know nothing of singing; as for dance, rare representations are known from icononography on vessels.

I will proceed according to the classification of Hornbostel and Sachs of 1914, who put all the known instruments of the world into a certain order which demonstrates relationships between sound-producing devices. When Hornbostel and Sachs wrote their article, very little was known about the instruments of the ancient Americas. However, newly discovered instruments from archaeological excavations fit perfectly well into this classification system. These instruments are are made mostly of clay, sometimes metal, hard wood or cane, seeds, stones, bone, snails and shells. The instruments were discovered in the Montana (the mountains), the Sierra (the lowlands). Nothing is known from the Yungas (rain forest).

Let's look at the pictures now. ${ }^{1}$ We see bells and jingles, mostly from the north, Colombia (Fig. 1). Next are rattles (Fig. 2), all of which are from different periods and cultures of South America. In the third illustration we have frame drums of different sizes and from different cultures (Fig. 3), double, threefold and quadruple clay whistles, all of which are made with a lot of creative fantasy (Fig. 4), vessel flutes (Fig. 5), long flutes (Fig. 6), panflutes of different sizes and shapes (Fig. 7, Fig. 8). Note that the Ecuadorian panflutes are quite different from the Peruvian ones.

${ }^{1}$ All the pictures of archaeological objects are from Hickmann 1990. 
The pipes on Ecuadorian panflutes are irregular in length; they do not follow each other in a row from long to short. Panflutes are not preserved in Ecuador, so we cannot measure their pipes. Lastly, we know of horns and trumpets (Fig. 9, Fig. 10). Now let's look at the multifunctional objects-whistling bottles (Fig. 11) and human figures (Fig. 12). We do not know their semantics, or their functions. Perhaps the whistling bottles served as containers for water or other fluids, whilst the human figures were puppets; ${ }^{2}$ or perhaps both objects were used for cultic purposes. Both objects have whistling devices attached or inside, so they have been interpreted as musical instruments. This is a typical problem of music archaeology — how can we understand all these objects from mostly oral cultures when written evidence is missing? We can study objects in terms of their material and their shape. Sometimes we can date them with archaeological methods. We can describe them, and, if playable, we can make acoustic studies, recording them and investigating their sonic characteristics. Sometimes there is an archaeological find context, when the objects have been found in tombs, settlements or the like. Music archaeology takes us so far, but we cannot learn more. Who made the instruments, for whom and how were they manufactured-and for which purpose? Who played them? These are the limits of music archaeology, which apply equally to general archaeology. Furthermore, when the instruments were excavated, the archaeologists often did not record anything about context - the circumstances, places and other objects they were found with.

Let us turn to Guaman's book now. First of all, I want to give you a short introduction to the author and his work. Felipe Guaman Poma de Ayala is his full name; we know very little about him. He was a nobleman, and a descendant from an Inca family. He was born in the northern Andes in 1535 or 1550 . He had several jobs during his life in Peru, working in the Spanish royal administration. He was condemned by the local governor at the end of the sixteenth century for unknown reasons, and he decided to travel around the Tahuantinsuyo, the Inca country of the Andes.

2 For the tradition of "puppets" in ancient America see E. Hickmann 2008, $147 \mathrm{ff}$. 
In that period he wrote his book, First New Chronicle and Good Government, which is concerned with the period directly following the Spanish conquest of 1532 onwards. The book itself dates to ca. 1600-1616. It consists of about eight hundred pages, handwritten in Spanish. Guaman Poma must have learnt Spanish as a child, when everybody had to learn reading and writing in schools. Guaman Poma's native language was Quetchua, and the book has countless expressions and also whole sentences in that language. The most important fact for us is that this book contains four hundred drawings showing the life of the Indians at the early period of the Conqista. It is the only South American work of a chronicler with such drawings; therefore it is extremely important. ${ }^{3}$

Guaman Poma mentions and draws instruments being played, dance and singing several times, mostly in his extended first part when he writes about the life of the Indians at the time of the early Conquista. The actual music is unknown, as musical notation was not used. Instruments were used in festivals of the Tahuantinsuyu inhabitants. Guaman Poma says that he writes only about the Indians of the Montana (the mountains), not of the Sierra (the lowlands) and the Yungas (rainforest). That may be the reason that he omits many instrumental types, most of which are preserved in the western Sierra of the Andes. Obviously, Guaman Poma documents instruments from the period right after the Conquista. Many Indian sound-producing devices must have disappeared, for unknown reasons. They do not appear in Guaman's book. I will show and comment on all items he has drawn in the hands of musicians. Were all the other types destroyed by the Europeans, or were they hidden by the Indians? We do not know whether the Inca still had them. The only known Inca instruments are whistling bottles, human figures with pebbles inside to make them sound, and rattles. No chronicler mentions them.

${ }^{3}$ I am quoting from the edition of John Murra, Rolena Adorno and Jörg Urioste of 1987. All the illustrations with musicians are taken from this edition. This book is divided into three volumes. Sometimes I consulted the abridged version in English by David Frye of 2006. 
Guaman Poma does not include many different instrumental types. The most frequently mentioned and drawn sound-producing item in Guaman's book is the frame drum. It appears exclusively in the hands of women. Its name in Guaman's text is tanbor, with the skin of a puma it is called puma tinya, and when it is made from human skin it is called runa tinya. When people were killed as a punishment their skin was used to manufacture a drum, and their bones were made into flutes. Drums were played at various occasions. In Fig. 13 we see drums at a royal marriage; the bride and another woman beat them with sticks. Inga Roca (a then historical Incan ruler) is shown at a certain distance. Drums are also played at a big festival of Inga Roca; many participants dance and sing, but only the drum is drawn, perhaps as a symbol for music. Many drummers accompany the festival of the sun. The drum is also beaten for the holy virgin at Easter festivals, together, with snails, conch shells, different flutes such as pingollos (long block and duct flutes, nowadays called pinkilla), antara (panflutes), pipo (whistles) and other instruments which are referred to using Quetchua terminology. Singing and dancing accompanied big royal festivals, such as a masked dance with drumming and singing. The conch shell is the horn of a natural snail, called mullu, or quepa or "trumpet." It is used mostly for signals of all kinds. In our next drawing we see it announcing a procession of penitence which took place regularly in January. According to the text, drums, flutes, trumpets and little bells are played during the procession, but only the conch shell is drawn (Fig. 14). The purpose of this procession was to banish diseases and "Pestilencia." Musical instruments, called musicas were present at funerals, as Guaman says. Flutes, together with a big drum, are combined with singing and dancing at a local festival (Fig.15) of which they had many. Although flutes or "pipes" were the only melodic instruments until the arrival of the Spaniards, they appear rarely. Let's look at a drawing of a dance at another local festival (Fig. 16). Here a panflute, an antara, is played by a dancer. This is the only time the antara is drawn by Guaman. Guaman says that the flute is called pipo, although it is normally called antara. The antara was the most well-known instrument in Peru, but in much earlier epochs and cultures, such as the Nasca. This instrument seems to have been forgotten by the time of Guaman Poma. About 1000 years had past, and the traditions concerning panpipes may not have been alive. There seems to be a 
sort of chronology in the book. The further the author proceeds with his writing, he stops mentioning Indian instruments. Instead, music-making Indians are shown engaging in Christian activities. Indians, all of which were baptised, appear as musicians in the long chapter about the church and church life. Here, the choir boys are dressed in the Spanish way, singing from a choir book, with European recorders in their hands and pressed against their lips (Fig. 17). More often they are ringing hand bells or church bells.

In Fig. 18 you see women drumming and two Indians, who seem to be dancing, in masks or special costumes blowing a vessel pipe.The text of the song is as follows: "If no venison passes by, if no deer shows up, you dance with the wayku under your nose. Ay little brother." So the whistles are intended to attract specific animals. The instruments are made of the heads of such animals, or they are made of clay, with attached antlers. Thus, the protagonists catch the deer by using their own voice. I have seen such instruments in Canada in a private collection; they sound hollow and have a warble tone, although no fingerholes. The song proceeds as follows: hauca, hano, huauco, chico, chico, chico, chico, yahahahaha... and so on. We learn that the instrument's name is wayku. In another picture we see the underworld; a big beast eats all the sinners, and out of his noseholes two horns are to be seen, obviously to underline the rough tone; the text says nothing about the instruments. In another picture a musical instrument seems to be a symbol for pleasure. We see two Criollos, a term used for the second generation of Indians with a Spanish father. Guaman Poma says here that the Criollos were lazy and did not want to work like in former times. They preferred to make music and to dance (Fig. 19). The man plays a guitar; Guaman Poma writes of taner, by which is meant the playing of an instrument and ringing church bells. But he does not mention a stringed instrument. In the English translation it is called a "mandolin" but that is, of course, a mistake.

We have learnt about the names of many musical instruments, sometimes in Quechua, about their function, i.e. whether they were played in festivals or other occasions, and about the occasions themselves. We have learnt who plays the instruments, so we can address gender issues, which archaeology by itself is not able to achieve. With the aid of music-archaeological methods we can study instruments, and examine archaeological contexts. 
Historiography can be the ideal complement to music archaeology or vice versa. As an example, the rich written evidence given by Guaman Poma de Ayala cannot be overestimated.

\section{BIBLIOGRAPHY}

Guaman Poma de Ayala, Felipe [ca. 1615] (1987). Nuéva Crónica y Buen Gobierno. Ed. John V. Murra, Rolena Adorno and Jorge L. Urioste. Crónicas de América 29a-c. Historia 16, Madrid.

Guaman Poma de Ayala, Felipe [ca. 1615] (2006). The First New Chronicle and Good Government. Abridged, selected, translated and annotated by David Frye. Indianapolis.

Hickmann, Ellen (1990). Musik aus dem Altertum der Neuen Welt. Archäologische Dokumente des Musizierens in präkolumbischen Kulturen Perus, Ekuadors und Kolumbiens. Frankfurt/M.

Hickmann, Ellen (2008). Klänge Altamerikas. Musikinstrumente in Kunst und Kult. Ed. Dieter and Evamaria Freudenberg and the Reiss-Engelhorn-Museen. Darmstadt.

Hornbostel, Erich M. von und Curt. Sachs (1914). "Systematilk der Musikinstrumente. Ein Versuch." In: Zeitschrift für Ethnologie 46. Jg. 1914, H. IV and V, 553-590. 


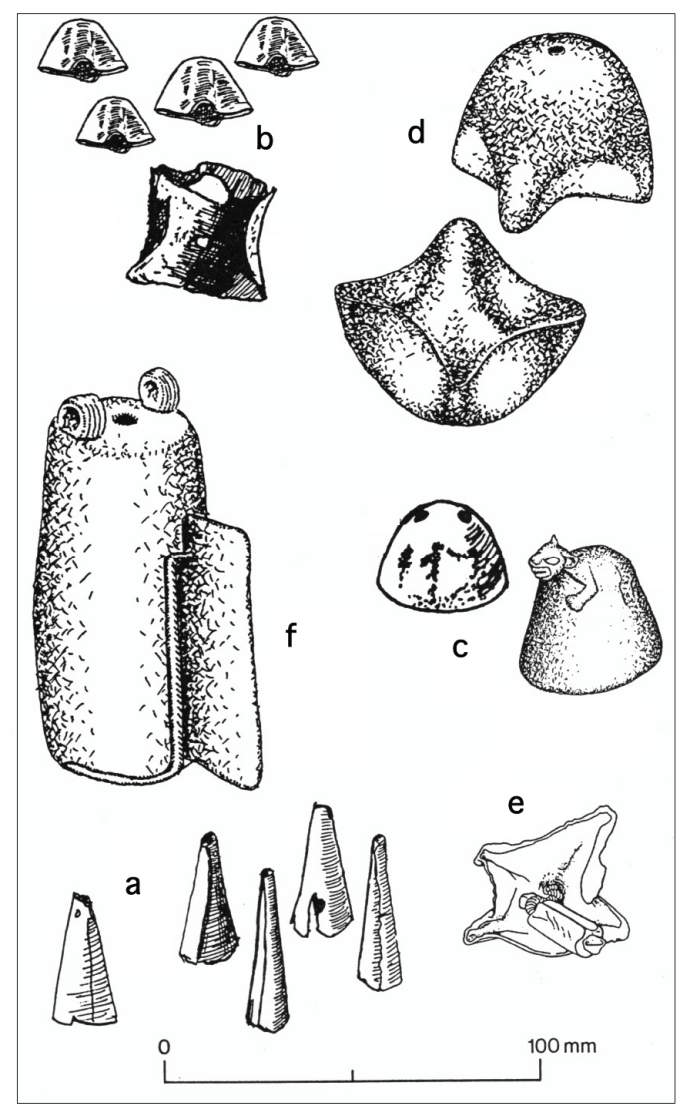

Fig. 1. Bells of tumbaga and silver

a, b Peru, Chimu culture;

c Peru, Nasca;

d Colombia, Tairona;

e Pachacamac, culture unknown;

f Colombia, Tairona. 


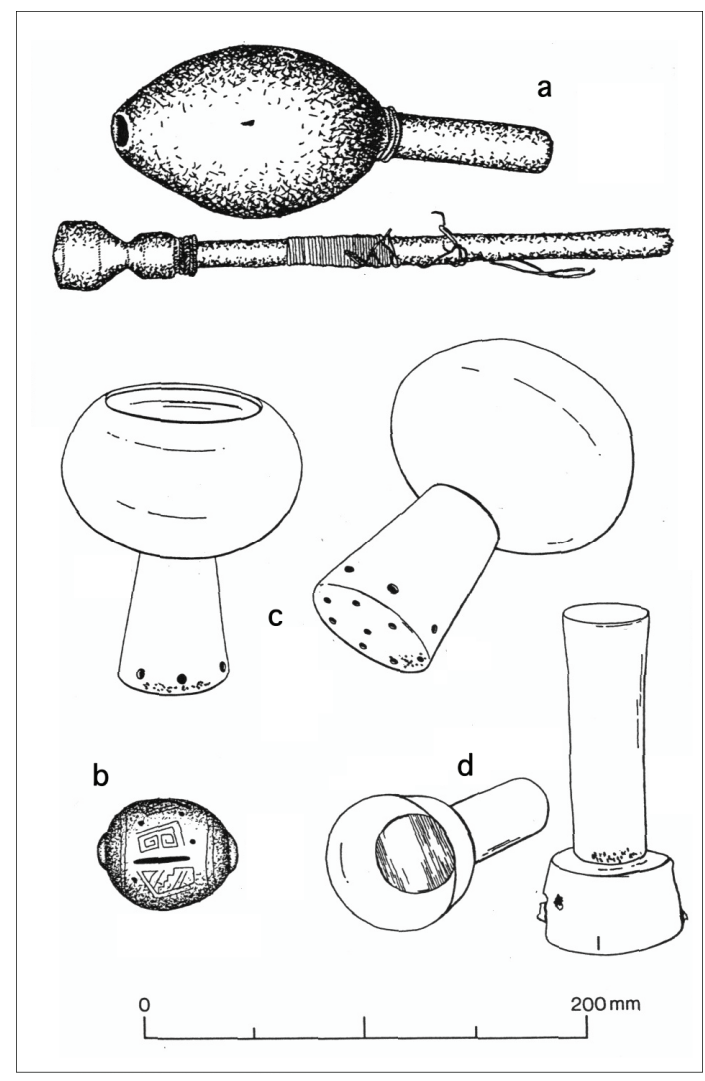

Fig. 2. Rattles

a Lima, culture unknown (wood);

b Ecuador, Guangala;

c Vessel with pebbles in its foot, Peru, Moche;

d Rattles of metal, Peru, Moche. 


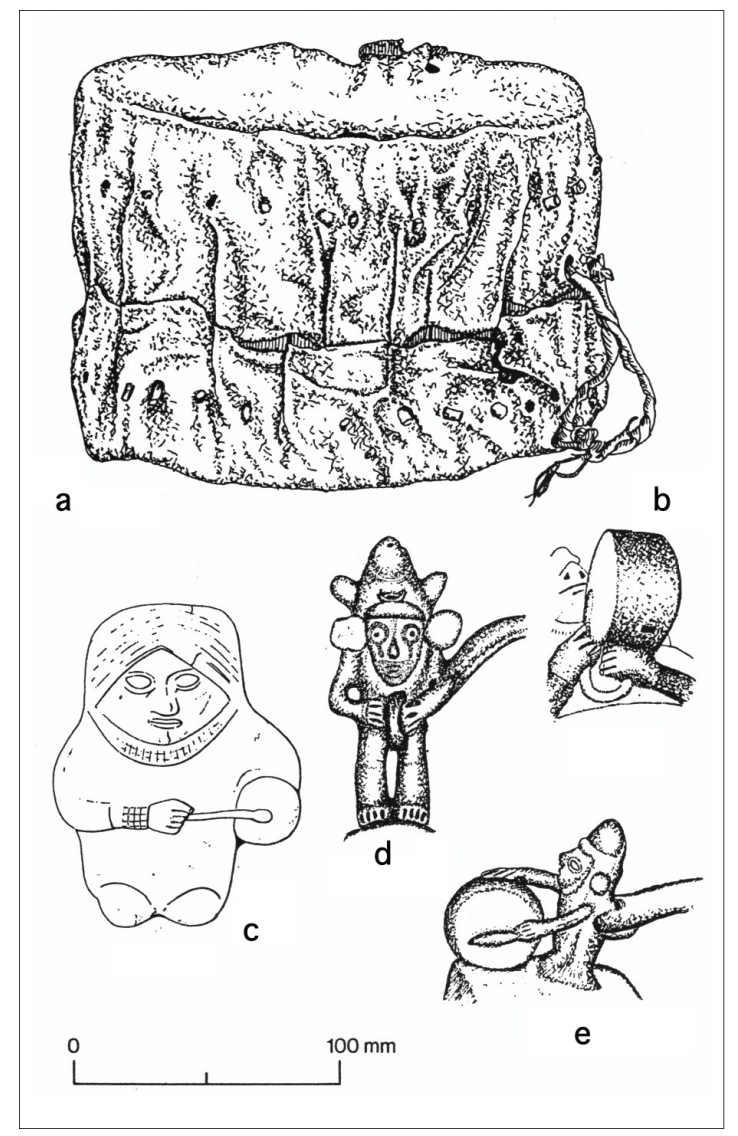

Fig. 3. Frame drums

a "huacho", culture unknown;

b, c Peru, Moche;

d Peru, Chimu;

e Peru, Chankay. 


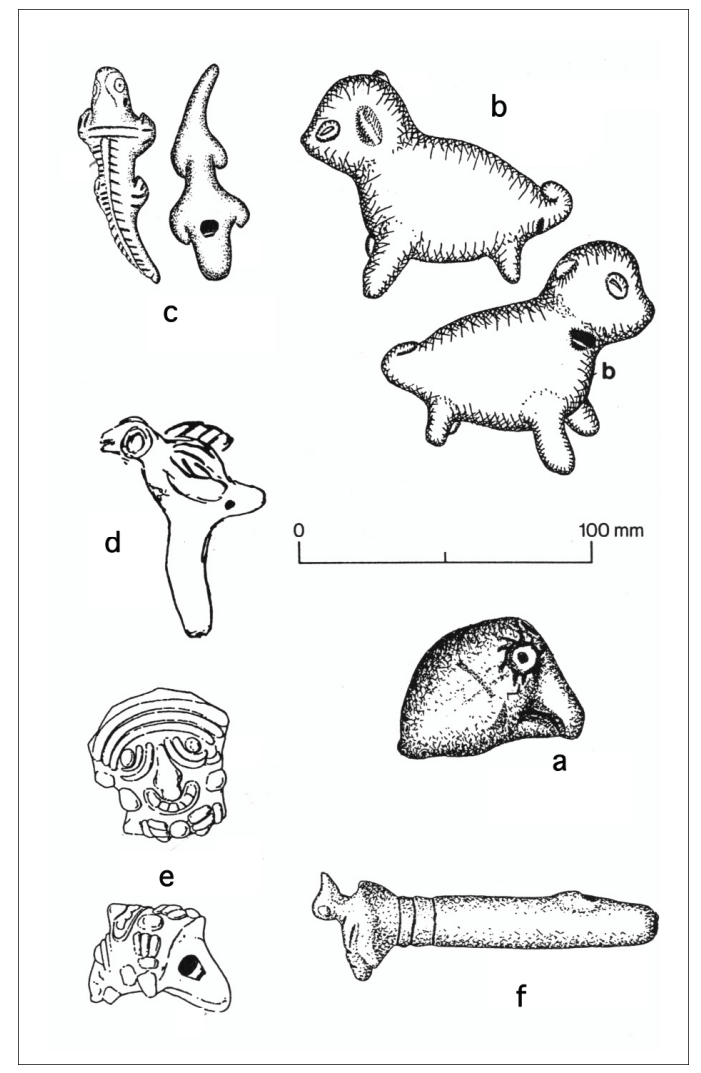

Fig. 4. Whistles

a "Pachacamac", culture unknown;

b, c Ecuador, Jama-Coaque and Bahia/Guangala;

d "Lima", culture unknown;

e Ecuador, La Tolita;

f Ecuador, Jama-Coaque. 


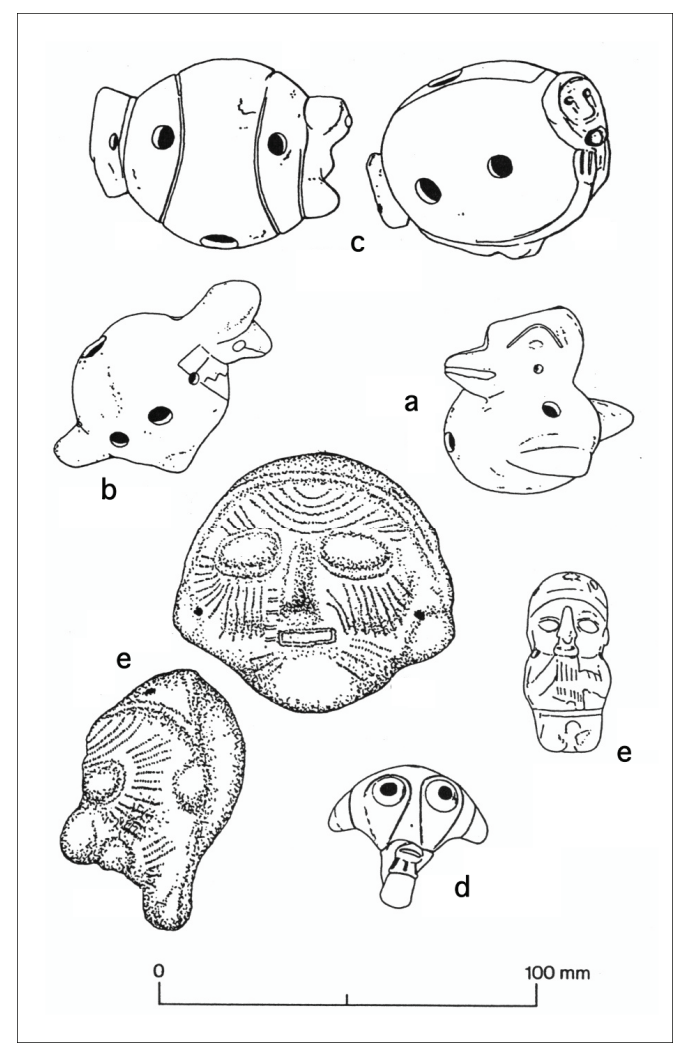

Fig. 5. Vessel flutes from Ecuador

a Chorrera;

b Tejar-Daule;

c Tachina; Guangala;

d, e Bahia. 


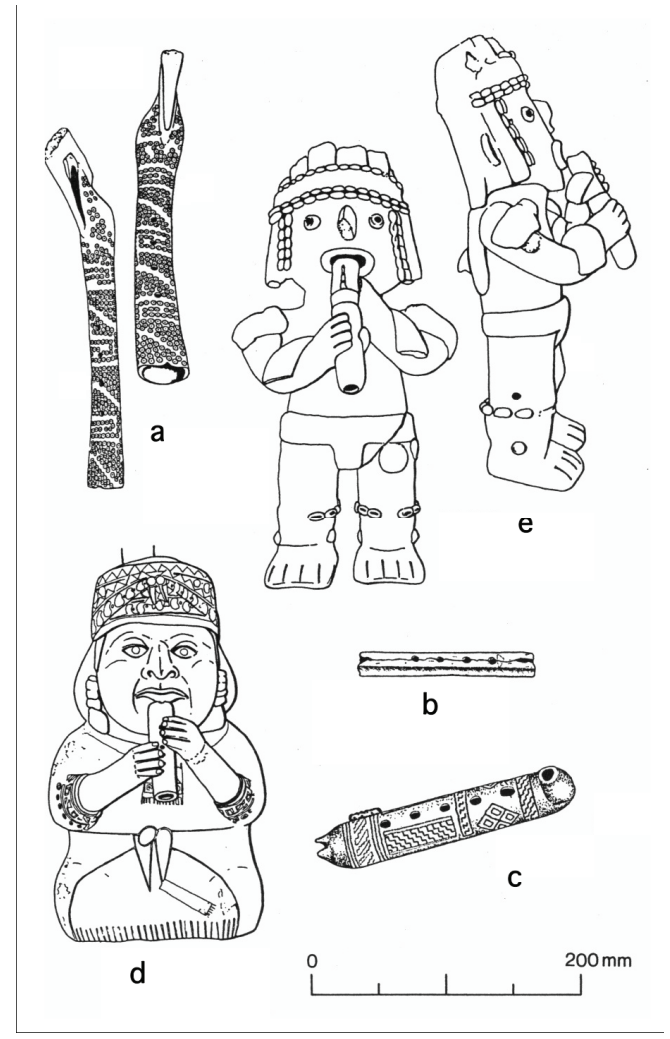

Fig. 6. Long Flutes

a Peru, Nazca;

b "Pachacamac", culture unknown;

c Peru, Ica;

d Peru, Moche;

e Peru, Ecuador, Bahia. 


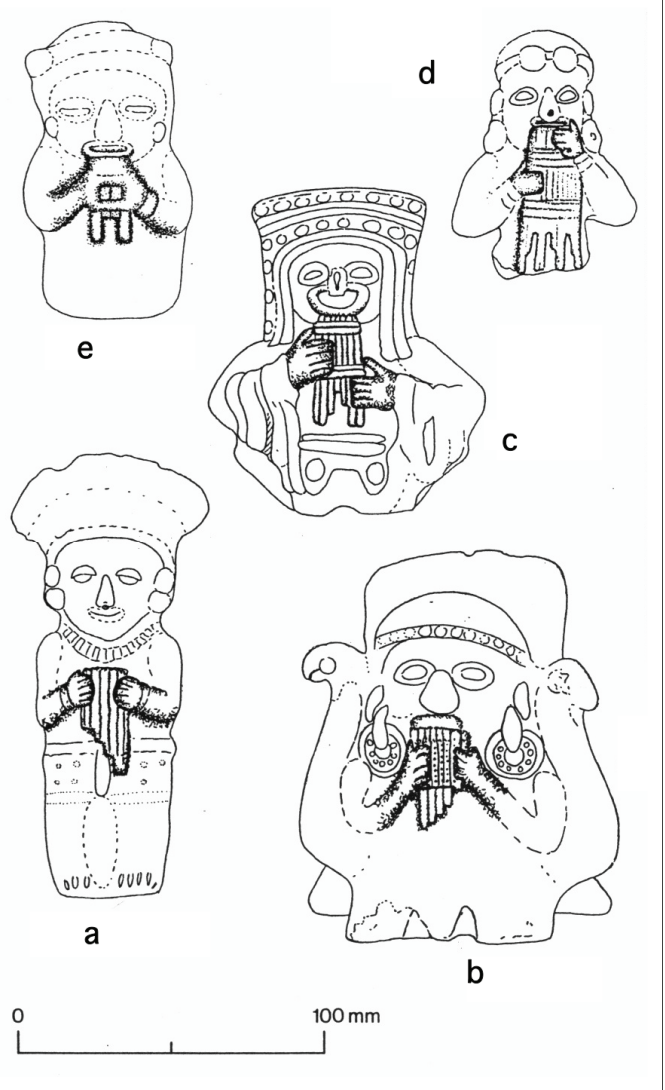

Fig. 7. Ecuadorian Musicians with Panflutes; clay figurines
a, e Bahia;
b Guangala;
c, d Tumaco. 


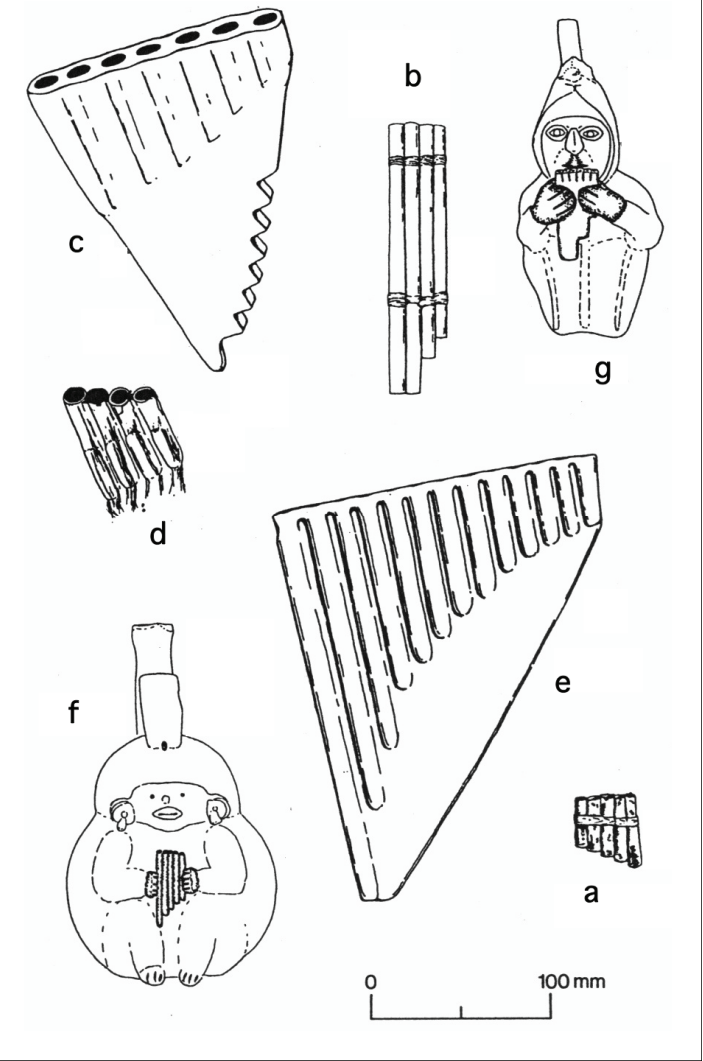

Fig. 8. Panflutes

a Peru, Chimu;

b Colombia, Quimbaya;

c, d, e Peru, Nazca;

f Ecuador, Chorrera;

g Peru, Moche. 

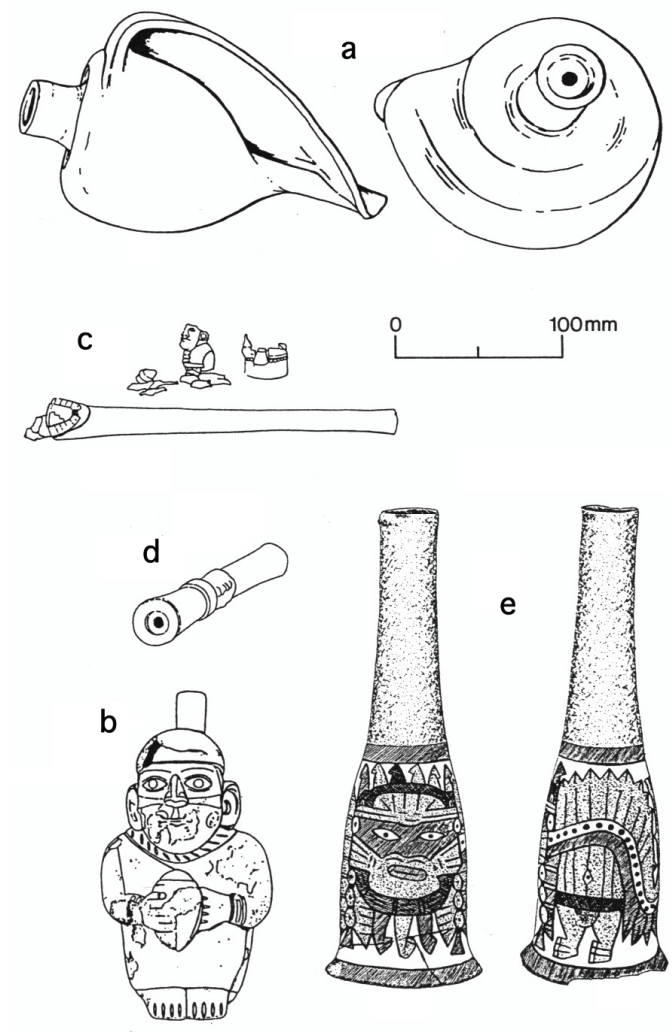

Fig. 9. Horns and Trumpets

a, b, c Peru, Moche;

d Peru, Chimu (of wood);

e Peru, Nazca. 


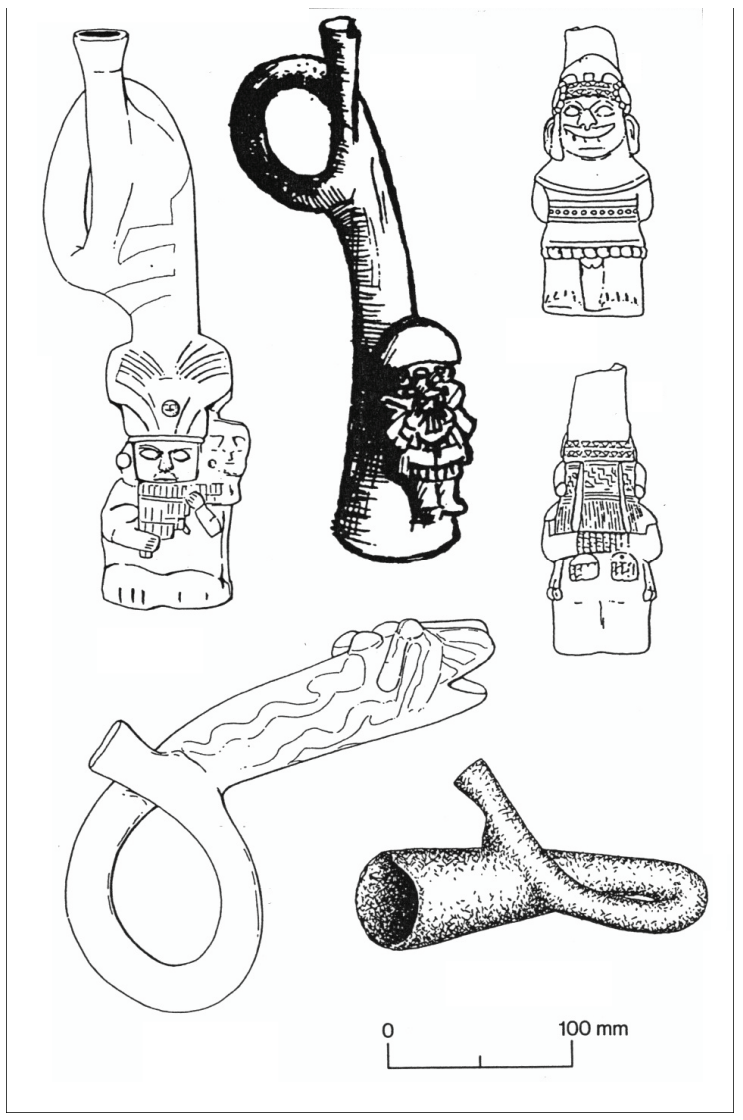

Fig. 10. Trumpets from Moche. 


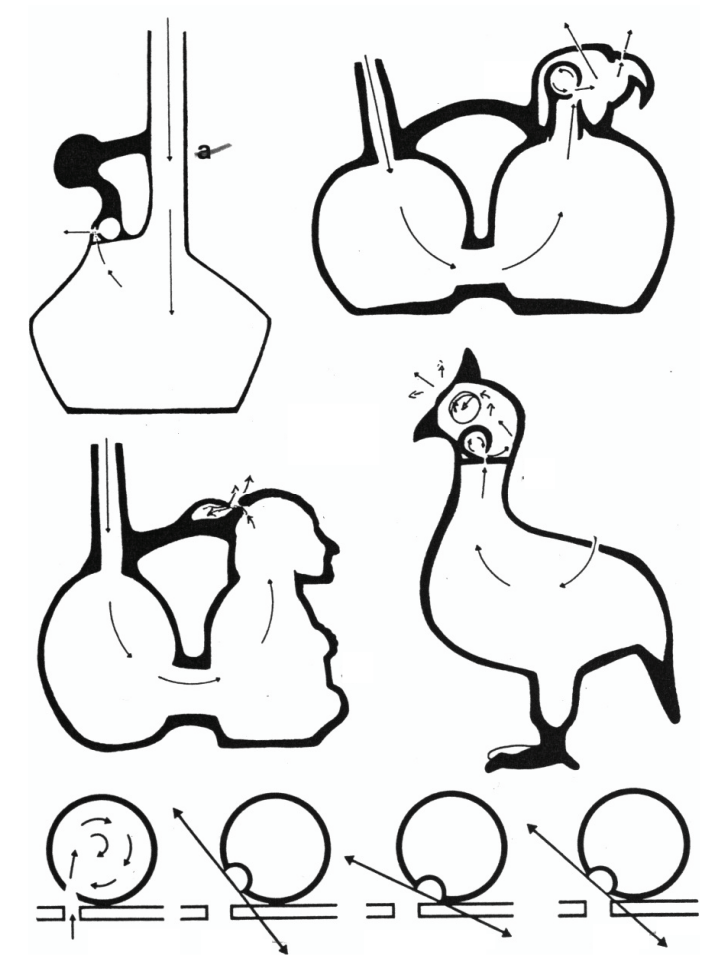

Fig. 11. Whistling bottles

The sound originates by pouring water into the neck of the single or double vessel, the air escapes by going through the whistling attachment producing a sound. 


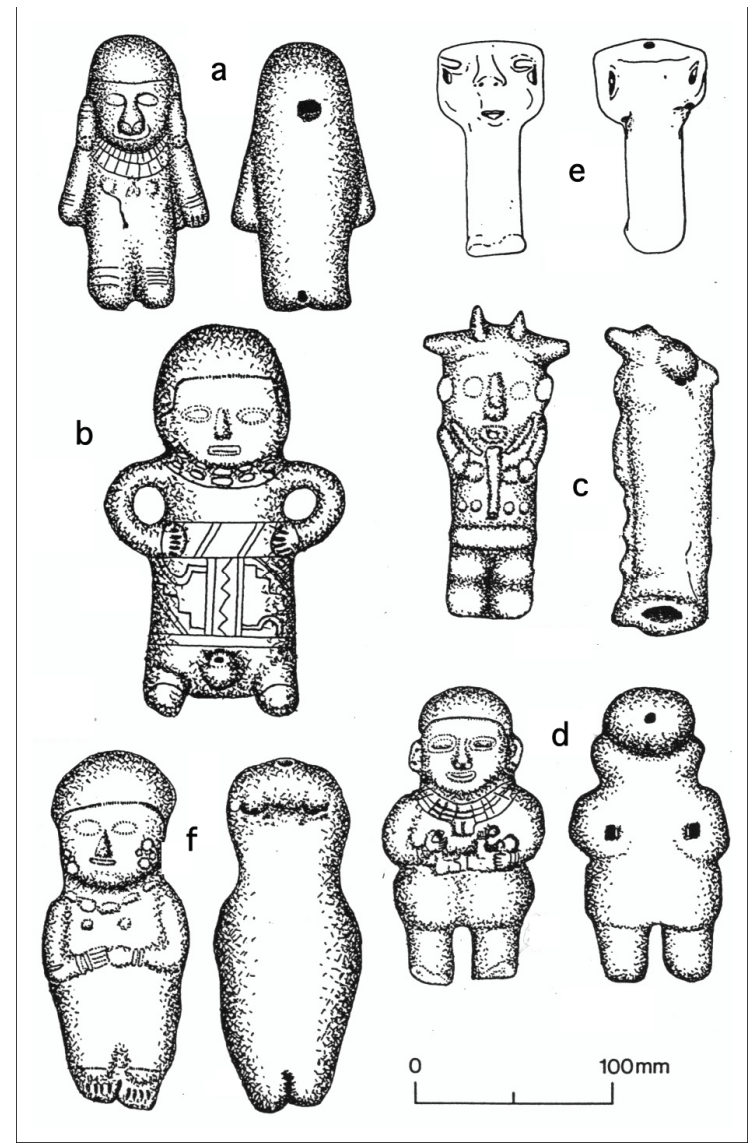

Fig. 12. Human figurines from Ecuadorian cultures.

They have a whistling attachmant on their back, on the sides of their head (e) or between their legs (b)

$$
\begin{gathered}
\text { a Jama-Coaque; } \\
\text { b Guangala; } \\
\text { c, f Bahia; } \\
\text { d La Tolita; } \\
\text { e Tumaco. }
\end{gathered}
$$




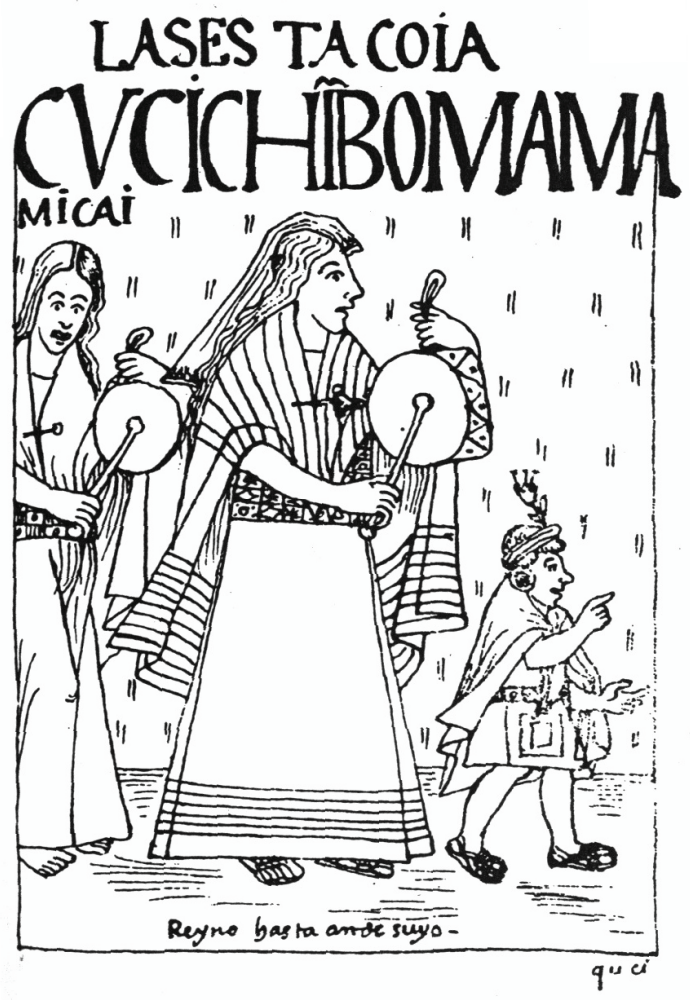

Fig. 13. Women beating their drums at a royal wedding. 


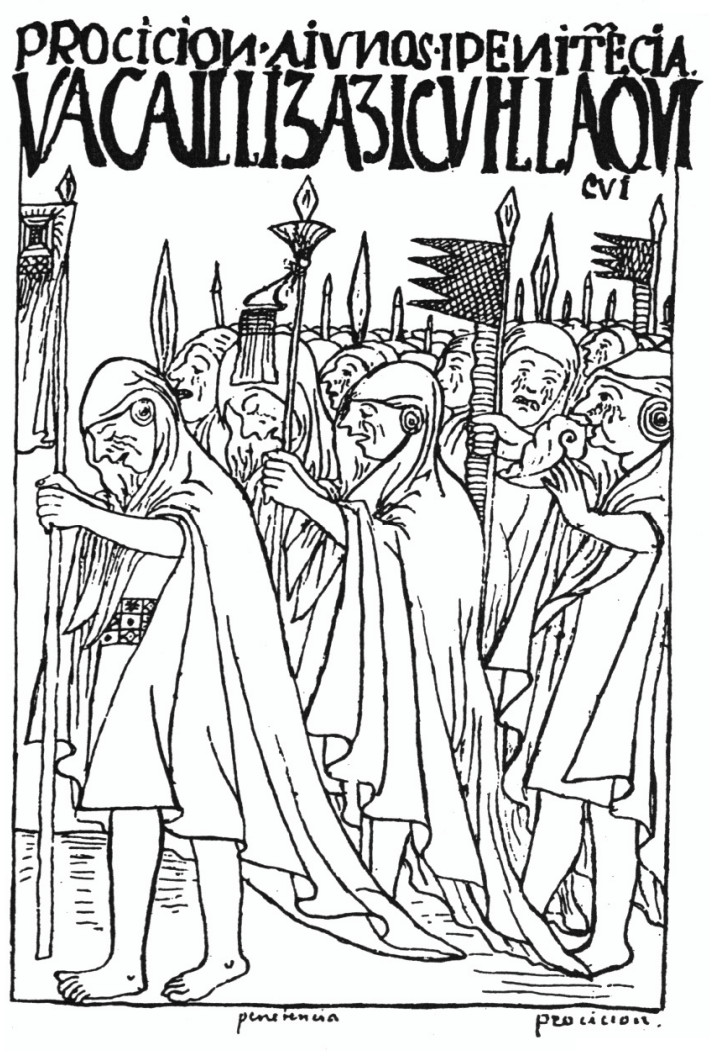

Fig. 14. Many instruments are played here as the text explains, but only the conch shell is drawn in the hands of a man.

All are in tears because of "pestilencia". 


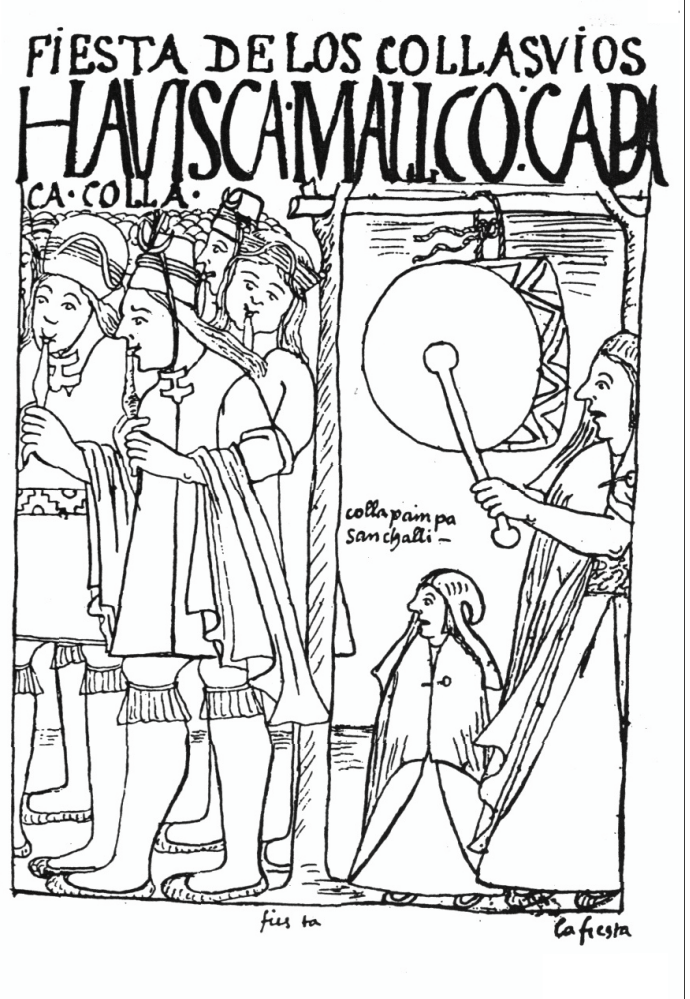

Fig. 15. Drum beating and flute playing at a local festival. 


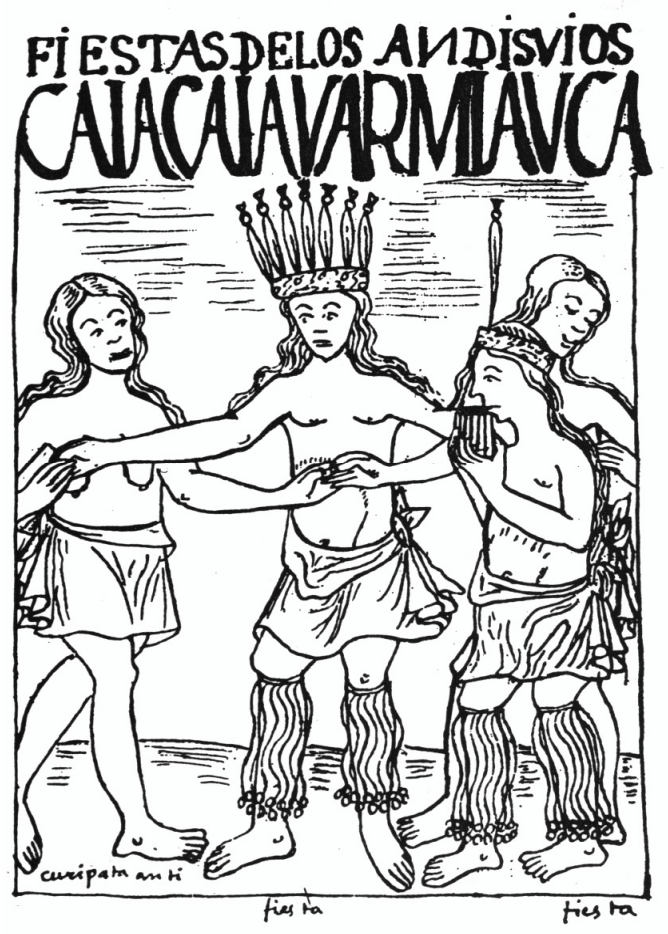

Fig. 16. antara player accompanying a local dance. 


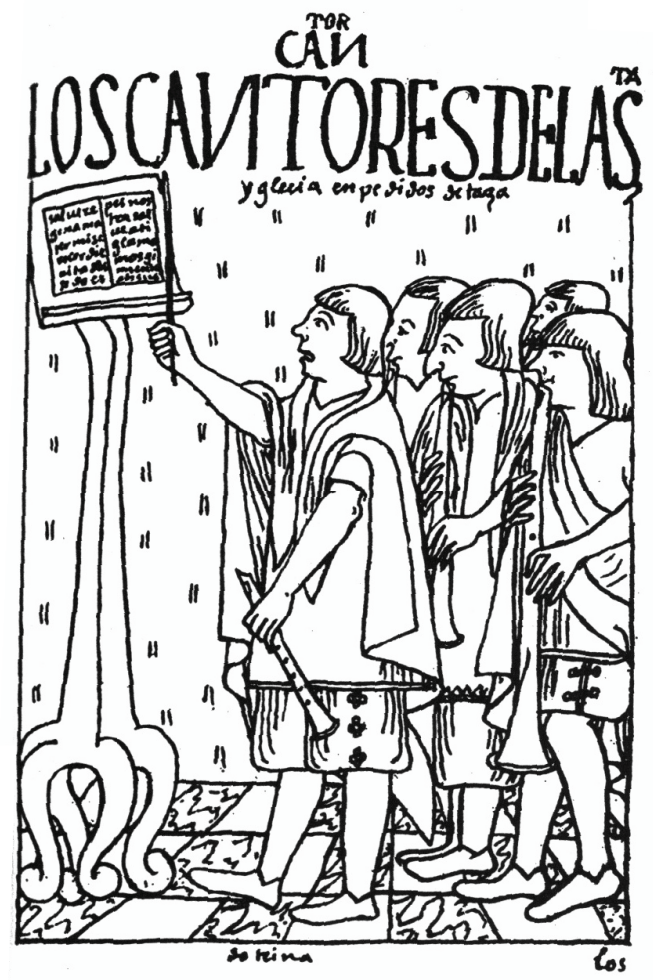

Fig. 17. Choir boys singing from a Christian choir book, holding and playing European recorders. 


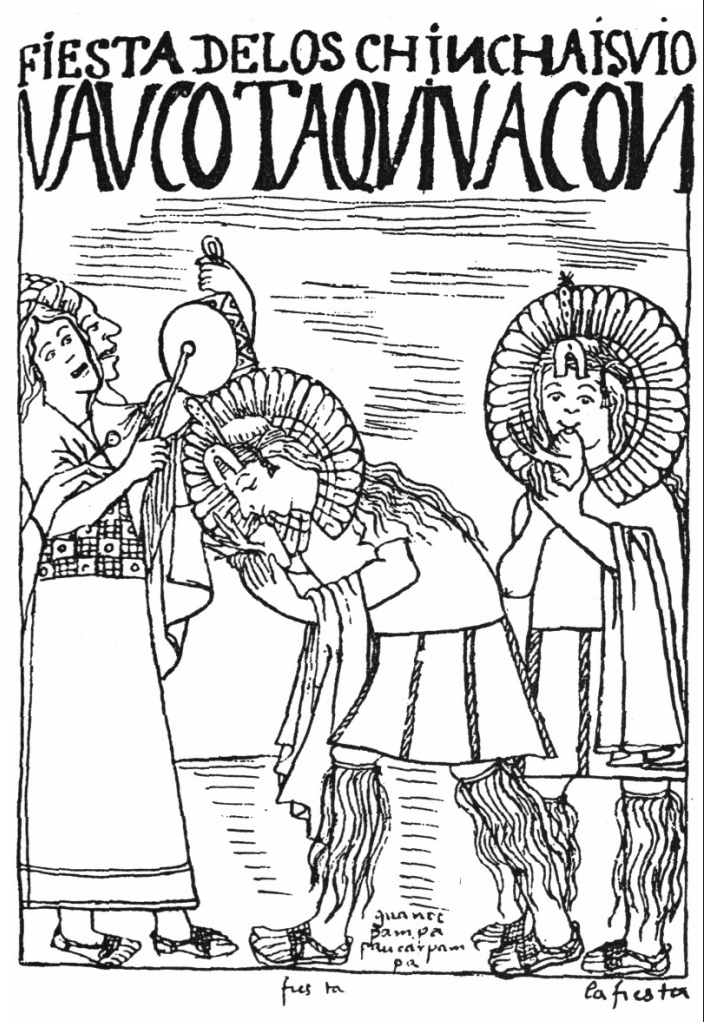

Fig. 18. Women beating the drum and men in costumes blowing antler whistles to attract venisson. 


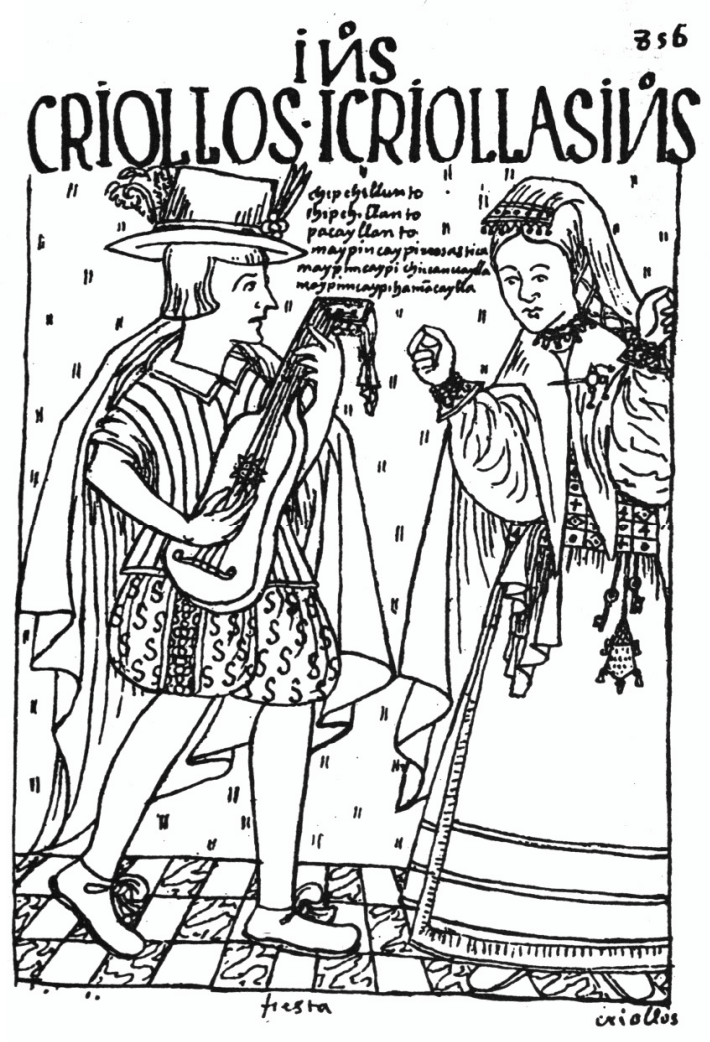

Fig. 19. Criollos dancing and playing the Spanish guitar. 


\title{
MUSIC-ARCHAEOLOGICAL RESEARCH ON Pre-Columbian Music Cultures 1880-1920
}

\begin{abstract}
ARND ADJE BOTH
In this paper the objectives, methods, and achievements of early researchers on pre-Columbian music are discussed, including distinguished scholars who played an essential role in the development of music-archaeological research in the Americas. Between 1880 and 1920, many important questions on music in the pre-Columbian societies were raised and even answered, but seldom reflected in later periods of research.
\end{abstract}

The first prolific phase of scientific research on the music cultures of the pre-Columbian Americas is characterized by a series of studies published between 1880 and 1920. In this period, Europe and North America experienced great scientific and technological advancement, while the world was extensively explored in the light of High Imperialism. This brought westerners not only to hitherto unknown remains of the so called high civilizations, but also in contact with the so called primitives, and their living cultures, including music. In the early phase of research, scientific analysis replaced general assumptions about the music of pre-Columbian societies, assumptions which were strongly influenced by ethnohistorical accounts from early Colonial times (sixteenth to the beginning of the seventeenth century) and subsequent historian's views. In the light of today's pluridisciplinarity, it is not surprising that the first steps to be undertaken in this field are characterized by diverse approaches, which were derived from, or were at least 
influenced by, various schools of the cultural and natural sciences. Whilst some disciplines were yet to be established in this period, most were in the process of rapid development.

The first researchers who published studies on pre-Columbian music cultures followed basically two directions without much interchange, although there was a constant flow of communication within the scientific communities, converging in the International Congress of Americanists, which held its first meeting in 1875 in Nancy, France. Historians, philologists, and linguists with a strong interest in music interpreted the written sources from early Colonial times, and wrote about the role of music and musical instruments in indigenous societies. Cultural anthropologists, namely archaeologists and early ethnographers with a strong interest in musicological problems, approached the topic from another angle. These researchers classified and described collections of pre-Columbian sound artefacts, which increasingly entered the art market and museums. Some scholars included acoustic analysis, and discussed the nature of pre-Columbian music. In this context, scale was one of the most important keywords.

Not surprisingly, much of this research was strongly influenced by current worldviews and the state of knowledge of the time. In some studies, diffusionism and Social Darwinism played a role, but many researchers in all fields of research largely avoided West-centric positions, and they undertook analytical and descriptive studies without emphasizing pejorative cultural values. These researchers, who were mostly unheard of in later times, deserve our special attention.

\section{ECHOES FROM THE DISTANT PAST: PERCEPTIONS AND MISCONCEPTIONS OF INDIGENOUS MUSIC}

One of the first records on ancient musical instruments and indigenous music traditions from the Americas was published in 1877 by the diplomat and archaeologist George E. Squier (18211888), in a work entitled Peru: Incidents of Travel and Exploration in the Land of the Incas, which was also translated into other languages, including German (1883). Squier, who was in Peru as United States Commissioner from 1862-1867, mentioned some musical finds, including a stone panpipe and a whistling vessel, and he stated that 
these objects might serve as a means of research on pre-Columbian music (Squier 1883, 218-222).

When reporting on a syncretistic feast from the Aymara region of the Bolivian highlands near Tiahuanaco (Fig. 1), Squier concluded that the "inharmonic noisy," "strange" and "wild" music performed nowadays must be a "true repetition of the ceremonies and customs" of ancient times (Squier 1883, 379). His description clearly represents a West-centric position, which had a strong and continuous tradition dating back to early Colonial times. In Squier's view, this indigenous music lacked melodious structures, which were replaced by the noise of "hollow" frame drums and "shrill" panflutes, whilst cow horns (possibly wakrapukus) were blown by "dilettantish" musicians among the spectators. As proof for his conclusions on the nature of pre-Columbian music, he quoted the account of the Spanish conquistador Bernal Díaz del Castillo, who characterized the Aztec music played in sacrificial rites and circular dances as wild, hollow (drums) and shrill (flutes), but also as terrifying, and diabolic (Squier 1883, 377-379; see Díaz del Castillo 1960 Vol. 1, 282, Vol. 2, 34, 39). Díaz del Castillo basically followed the musical aesthetics of the Renaissance and the religious worldview of early Colonial times, which was a means of justifying the destruction of indigenous societies in the course of the Hispanic colonization of the Americas. Squier and many subsequent observers of indigenous music traditions followed nineteenth century perceptions and cultural misconceptions, which in comparison with indigenous aesthetics, differed little from earlier views.

\section{THE QUESTION OF MUSICAL SCALE}

One of the first researchers on pre-Columbian music was the archaeologist and physician Hillborne T. Cresson (?-1894), whose study entitled Aztec Music was published in 1883 by the Academy of Natural Sciences of Philadelphia (Cresson 1883). Cresson carefully examined five Aztec flower-flutes preserved in the Pennsylvania Museum of Archaeology with the aim of reconstructing pre-Columbian manufacturing techniques and musical scales. With the help of a professional musician, Prof. J. S. Cox, who used the Boehm flute as a pitch reference, a series of individual finger combinations including cross-fingerings were recorded. Using half-stops and closing the bell with the finger, 
fundamental notes in the range of whole tones and semitones were obtained (Fig. 2).

Remarkably, Cresson and his musical expert did not conclude on the employment of pentatonic scales, thus opposing a widely accepted assumption. Instead of what Cresson called a "hasty conclusion" raised by "musical authorities" (possibly referring to musicologists, who observed contemporary indigenous music in a West-centric view), he stated that on the flower-flutes the chromatic and diatonic scales can be produced within a full octave:

Musical authorities seem to have arrived at the some point hasty conclusion, that the Aztec people were only possessed of a knowledge of the so-called pentatonic scale, but with all due difference to their opinion, I must beg leave differ upon this point, as it is not probable that intervals which are so easily obtained, were unknown to artisans capable of manufacturing these flageolets of terracotta, pitched in different keys, and of determining the exact distance apart of the finger-holes. [...] The more I study the musical instruments of these people, the firmer becomes my conviction that they must have possessed a full knowledge of the diatonic and chromatic scales; which can be produced upon the four-holed clay flageolets by any one capable of manipulating our modern flutes [...] (Cresson 1883, 91).

As opposed to other scholars, who accepted the conclusions drawn from ethnohistorical accounts and descriptions of contemporaneous indigenous music traditions, Cresson focussed on material culture, including precise methods of organology and acoustics. One hundred and twenty years later, his results could be confirmed on the basis of the acoustics of a set of five flower-flutes preserved in the Ethnological Museum, Berlin (Both 2002).

\section{READING BETWEEN THE LINES}

Daniel G. Brinton (1837-1899), then Professor of American Archaeology and Linguistics at the University of Pennsylvania (and thus located in the same city as Cresson, Philadelphia), approached pre-Columbian music cultures on the basis of written sources. Amongst his wide spectra of research, Brinton translated and interpreted sixteenth/seventeenth century texts written in Nahuatl, the language of the Aztecs. 
In two volumes published in 1890, Ancient Nabuatl Poetry and Rig Veda Americanus: Sacred Songs of the Ancient Mexicans, Brinton translated texts of Aztec ceremonial chants written down by the Franciscan Fray Bernardino de Sahagún, missionary, chronicler and early ethnographer, who compiled one of the most important sixteenth century records on the Aztecs (Brinton 1890a and 1890b). In the introduction to Ancient Nahuatl Poetry, Brinton discussed the role of song and music in Aztec society. In chapter six, "The Instrumental Accompaniment," Brinton referred to the related Aztec terminology of musical instruments, gave translations, and discussed their individual function (Brinton 1890a, 21-26). Therefore, he did not only repeat statements of earlier nineteenth century historians, but he also compiled much of the most important information given by sixteenth century missionaries and chroniclers. In doing so, he was among the first to discuss the related terminology of Aztec musical instruments, a terminology rich with information on their individual meaning and function.

Brinton, who knew Cresson, and visited the pre-Columbian collection of the Pennsylvania Museum of Archaeology, also referred to his colleagues' studies, stating that the results indicate "for the instrumental accompaniment a much higher position in musical notation than has hitherto been accepted" (Brinton 1890a, 26). However, although Brinton had a much more powerful voice in American cultural anthropology than Cresson, this position did not become widely accepted.

In Ancient Nahuatl Poetry's chapter eight, entitled "The Preservation of the Ancient Songs," Brinton referred to Sahagún, who mentioned that specific "books of song" (cuica amath) existed (Sahagún 1950-1982, Vol. III, 65). Brinton suggested that the preserved codices contain musical information: "[...] it was quite possible to preserve the sound as well as the sense of sentences and verses" (Brinton 1890a, 31). Until then, few researchers referred to Sahagún's passage, but the problem was never further developed due to the lack of additional information. That pre-Columbian codices included a form of notation based on oral tradition is also indicated by the Cantares Mexicanos, a sixteenth century collection of ninety one Aztec chants, for which the instrumentation and a syllabic codification of drum patterns are given, which is a subject of differing interpretations (Garibay 1953-54; Mendoza 1956; Nowotny 1956; Ziehm 1976; Haly 1986; and others). Although it is 
possible that some ancient manuscripts served as a mnemotechnical device for ritual song, and that musical patterns were graphically fixed, it is probable that no pictographic "book of songs" of pre-Columbian societies survived.

\section{ON THE ORIGINS OF WINDS AND STRINGS}

When Cresson and Brinton published their groundbreaking studies, more and more explorers travelled through the Americas, bringing notes and artefacts back home. Not surprisingly, in the following years descriptions of pre-Columbian musical instruments were increasingly published. At that time, some of the objects in question, such as the Aztec flower-flutes in Philadelphia, belonged to museum collections; others were obtained on the art market or excavated in the course of early archaeological activities.

At the beginning of this phase, two researchers, the anthropologist and zoologist Julius Kollmann (1834-1918) and the anthropologist and archaeologist Leo Frobenius (1873-1938) published pre-Columbian musical instruments preserved in the ethnographic collection of the University of Basel (Kollmann 1895 and 1896; Frobenius 1896). While Frobenius examined an Aztec slit-drum (teponaztli), Kollmann carefully described organological details of Aztec wind instruments, including a skull-shaped whistle (Fig. 3), but without going into acoustic details. In an updated version from his paper published in 1896, Kollmann stated that the shell trumpet could have been invented independently in the Americas, and must not necessarily be a European or Asian import, thus speaking against diffusionist views and in support of polygenesis.

In 1897 and 1898 a dispute was prematurely settled on the origins of the musical bow and stringed instruments in the preColumbian Americas (Brinton 1897; Sapper 1897; Mason 1897 and 1898; Saville 1897 and 1898; Kate 1898; Hawley 1898). In a short paper, Brinton referred to examples of monochords from North America (the tsii', or so-called "Apache fiddle", and a string instrument of the Mississippi-Nachee [Natchez] Indians), Central America (the Nicaraguan and Costa Rican musical bow quijongo), and South America (a string instrument from the upper Purus River, Brazil). He stated: "It is possible that in all these cases the instruments were borrowed with modifications from the whites or negroes; but there is sufficient probability that they were aboriginal 
American inventions to make their further study desirable" (Brinton 1897, 19-20). In the same year, the anthropologist and archaeologist Marshall H. Saville (1867-1935), curator of Mexican and Central American archaeology at the Museum of the American Indian, New York, described a mouth bow called hool played by the Maya peasants who helped in the 1890/91 excavation of the Loltún cave, peninsula of Yucatán, Mexico, without considering the historical dimension of this instrument (Saville 1897). The geographer and anthropologist Carl Sapper (1866-1945), then representative of the German consul in Guatemala, described the musical instruments and music of the Maya, including transcriptions; Sapper suggested that stringed instruments were common in pre-Columbian times (Sapper 1897, 312). In the same year the ethnologist Otis T. Mason (1838-1908), curator at the United States National Museum, adopted an opposite opinion in his Geographical Distribution of the Musical Bow. Mason concluded that "stringed musical instruments were not known to any of the aborigines of the Western hemisphere before Columbus" (Mason 1897, 380). A year later, Herman F. C. ten Kate described a musical bow from Patagonia, Chile, and proposed that stringed musical instruments did exist in the pre-Columbian Americas (Kate 1898, stated in Saville 1998, 281). The same year, Mason and Saville published further statements. While Mason expressed his disagreement with Brinton, Sapper and others (Mason 1898), Saville searched for proof for the existence of string instruments in pre-Columbian iconographic records (Saville 1898). He believed that he found this proof in the famous palace ensemble depicted in the Mixtec Codex Becker, in which the last musician in the row was believed to play a mouth bow (Fig. 4). In the same year, E. H. Hawley, head of the musical collection at the United States National Museum, disagreed with Saville, but was also wrong in interpreting the depiction as the player of a bone rasp (Hawley 1898). Comparable depictions reveal that the person in fact plays the turtle shell with a deer antler.

While it has long been accepted that certain string instruments, such as the quijongo, found their way to the Americas due to the import of African slaves, the question of the employment of the musical bow in pre-Columbian societies remains unclear. So far, no pre-Columbian depiction of a stringed instrument can be identified without question. The supposed 
"stringed instrument" depicted on the Maya vase K5233 (according to the designation by Justin Kerr) possibly represents a friction drum (Donahue 2000), although this interpretation is also unclear.

\section{THE BONE RASP}

In 1898 a debate commenced on the bone rasp made from human femurs and its use and function in indigenous societies, starting with the above mentioned E. H. Hawley, the anthropologist Frederick Starr (1858-1933), professor at the University of Chicago, and Eduard Seler (1849-1922), the latter playing a prominent role in the following years (Hawley 1898; Starr 1898; Seler 1898). In the same year, the explorer and ethnographer Carl Lumholtz (1851-1922) and the physical anthropologist Aleš Hrdlička (1869-1943) carefully described twenty six bone rasps excavated at Zacápu in Michoacán, Mexico, but did not comment on their musical function, interpreting the objects as tallies or trophy counts (Lumholtz/Hrdlička 1898; see Pereira 2005). The bone rasp, a friction instrument frequently misinterpreted as a rattle, fascinated the researchers of the time, as more papers on the subject were published until the end of this period of research (Capitan 1908; Beyer 1916). All researchers did not comment on a Mixtec or Aztec bone rasp with a turquoise mosaic and a small oliva shell with an attached copper chain (Fig. 5), which is preserved in the Museo Nazionale Preistorico Etnografico "L. Pigorini" in Rome, published in 1885 by the museum's founder, the Italian archaeologist and ethnographer Luigi Pigorini (1842-1925). This object, and Aztec votive objects depicting rasps excavated in the grounds of the Aztec temple precinct, indicate the playing technique of these instruments, using the small oliva shell as the scraper. Metal chains of the type attached to the bone rasp in Rome were uncommon in pre-Columbian times and must have been added after the Conquest, indicating some sort of subsequent use of the object. In pre-Columbian times, stripes of cotton were used to attach the shell.

\section{THE FIRST STORAGE HALL PLAYERS}

1898 was a key year for music archaeology of the Americas. In Washington, two archaeologists and curators attached to the Smithsonian Institution, Thomas Wilson (1832-1902) and William 
H. Holmes (1846-1933), published catalogues of pre-Columbian musical instruments (Wilson 1898, 512-664; Holmes 1898, 50-53, 156-171). For the acoustic and organological analysis, Wilson worked closely with E. P. Upham. A footnote states: "Much of the material descriptive of prehistoric musical instruments and their scales in the Western Hemisphere [...] was prepared by Mr. E. P. Upham, assistant in the division of Prehistoric Archaeology, to whom credit as joint author should be given" (Wilson 1898, 512).

In contrast to Kollmann and others, Wilson/Upham and Holmes described the fundamental notes obtained on individual instruments, also indicating finger combinations with open and stopped finger-holes. Wilson/Upham, for instance, gave the notes of ten finger combinations of an Aztec flower-flute, with normal air pressure and overblowing (Fig. 6), but they did not contribute to the discussion on pre-Columbian scales (Wilson 1898, 605). In following western notation, these researchers did not measure microtonal pitch deviations, and thus they recorded only approximate values. As representatives of artefact-based archaeology, where lists and exact descriptions played a prominent role, they are amongst the first systematic "storage hall players" of the ancient musical instruments of the Americas (not forgetting Cresson as a forerunner). As in most early studies of acoustics, Wilson and Holmes did not specify their methods. Probably, musical instruments such as the Boehm flute or tuning forks were used as pitch references. The values given are only approximate from today's point of view. Tuning forks were tuned in most cases lower than $\mathrm{A}=440 \mathrm{~Hz}$, as now.

Wilson, then curator of the Division of Prehistoric Archaeology of the United States National Museum in Washington, had a comprehensive agenda, including not only North American, Mesoamerican, Central American, and South American finds, but also prehistoric European material. In comparison, Holmes, as head curator of anthropology at the U.S. National Museum, focussed on the archaeological remains of Chiriquí, a coastal province in Panama, where beautiful ceramic wind instruments, rattles, and drums were produced. Based on his skills as a professional scientific illustrator, he was the first researcher who included cross sections of some of the discussed instruments, thus 
obtaining a more precise organological description. Such methods were far from being systematically applied at this time.

There were at least a few followers of the Wilson/Upham and Holmes school, including archaeologists and curators such as Charles W. Mead (1845-1928) and George Grant MacCurdy (18631947). At a time when the organological classification of musical instruments was still in its infancy, Mead published the first catalogue of pre-Columbian musical instruments in an exhibition: The Musical Instruments of the Incas: A Guide Leaflet to the Collection on Exbibition in the American Museum of Natural History (1903). Following a common classification system of the time, he subsumed drums, bells, rattles and cymbals from shell under percussion instruments. Furthermore, he subsumed diverse flutes and trumpets under wind instruments, resulting in a good survey of Peruvian instrument types known up to then. In his acoustical analysis, Mead established a systematic comparative approach in comparing the fundamentals obtained on twenty six end-blown flutes from cane, bone, and gourd, coming to the following conclusion:

All attempts to discover any rule or law governing the positions of the openings or vents have been unsuccessful. A first glance at several of these flutes, particularly those made of cane, gives the impression that an attempt at equal spacing had been made; but a second shows such a variation in distances that this seems doubtful. The bone flutes [...] are of the same length, yet a great difference in the position of the holes is apparent at glance. We are led to the conclusion that these ancient flute-makers were not governed by set laws, but that each made his instrument according to his own idea. That the tones produced are in false key-relationship is not to be wondered at when we consider the imperfections in their construction; in fact the flutes are sadly out of tune (Mead 1903, 17).

Although adopting a west-centric approach, Mead did not completely deny the existence of a specific indigenous musical aesthetic, with regard to the instruments. He observed that some finger-holes of the bone flutes were plugged with a substance, and other finger-holes were bored nearby (Mead 1903, 20; see Gudemos 1998). Although to him, most instruments indicated the 
use of a pentatonic scale, he stated that "there are some puzzling exceptions," and that more instruments would need to be collected and tested in order to determine the ancient indigenous intervals (Mead 1903, 31). In a short chapter, he referred to the 1897/98 dispute on stringed instruments, and he supported the standpoint of Mason and others: "Although not conclusive, such evidence as we have at the present time is against the existence of any form of stringed instrument in Peru before the coming of the Spaniards" (Mead 1903, 30).

MacCurdy, then assistant professor of archaeology and curator of the anthropological collection of Yale University, described a collection of archaeological objects from Colombia, including ceramic rattles, duct flutes, and metal bells, thus continuing the studies of Holmes in A Study of Chiriquian Antiquities (1911, 169-188, 198, 201). He played and described a series of comparable instruments, adding beautiful drawings (Fig. 7), and gave precise descriptions of the acoustic properties and playing possibilities of the instruments. On the typical sound of Chiriquian globular flutes with two finger-holes, he stated:

While the power and range of these whistles and flutes are limited, the quality of the tone is often melodious. There are generally three whole tones, each of the two intervals forming a major second. Sometimes the first interval is equal to one and a half whole tones, i.e., a minor third, making the compass from the lowest to the highest tone equal to the first four notes of the scale, instead of the first three. [...] The holes are usually so nearly of the same size that it makes no difference which is opened first. The pitch can be made to vary with the force of the breath. By making judicious selections, a number of instruments may be played in unison (MacCurdy 1911, 170).

This description demonstrates that MacCurdy played the instruments experimentally, including different techniques (e.g., breath control) and simultaneous playing of sound artefacts. His results could be confirmed by the experimental playing of Aztec ceramic flutes recently (Both 2005, 122). MacCurdy is probably the first author who described combination tones ("a shrill ear-splitting sound") produced on high-pitched pre-Columbian double whistles, which were common in many ceramic cultures of the Americas (MacCurdy 1911, 170). 


\section{MUSIC BETWEEN THE SAVAGE AND THE ENLIGHTENED}

In his Contribution to the History of Musical Scales from 1902, the physician and US Patent Office examiner Charles Kasson Wead carefully examined the tonal ranges of a variety of pre-Columbian wind instruments. In contrast to the approach followed by Wilson/Upham, Holmes, and Mead, Wead used exact acoustic calculations and precise analytical methods, but he also adopted the common social Darwinistic worldview of his time. He is certainly the most ambivalent of the scholars mentioned in this paper. Weed established four stages in the development of musical scales, roughly corresponding with the culture stages of the evolutionists, namely the savage, barbarous, civilized, and enlightened: " 1 . The stage of primitive music, where is no more indication of a scale than in the sounds of birds, animals, or of nature. 2. The stage of instruments mechanically capable of furnishing a scale. 3. The stage of theoretical melodic scales (Greek, Arab, Chinese, Hindu, Mediaeval, etc.). 4. The stage of the modern harmonic scale and its descendent, the equally tempered scale, which are alike dependent both on a theory and on the possibility of embodying it in instruments (Wead 1902, 421)." Wead came to the conclusion that pre-Columbian musical instruments belonged to the second, barbarous stage, in which the indigenous people were only "mechanically capable of furnishing a scale," and added:

[...] the whole discussion makes it evident, that the people who made and used these instruments [...] had not the idea of a scale which underlies all our thinking on the subject, namely: A series either of tones or of intervals recognized as a standard, independent of any particular instrument, but to which every instrument must conform. Modern Europeans for the sake of harmony nearly banished all scales but one [...]. But for these people the instrument is the primary thing, and to it the rule is applied, while the scale is a result, or a secondary thing; and the same rule applied a hundred times may possibly give a hundred different scales. Naturally one does not expect to find much concerted music among people in this stage of development (Wead 1902, 438).

Wead's analyses are an example of objective analytical results applied to a questionable evolutionary model. Wead discovered that the measurements of pre-Columbian flutes only roughly 
correspond to each other and that no instrument of the same type is exactly the same. In applying western playing techniques he also discovered that most pre-Columbian flute types can play in unison when different air pressures are applied, if that was ever desired.

\section{The SELER SCHOOL}

1898 was also the year in which decades of research on preColumbian music cultures influenced by the German scholar Eduard Seler (1849-1922) began, and when archaeological finds, written sources, and iconographical data were systematically compared. In a similar fashion to his distinguished forerunner, Daniel Brinton, Seler incorporated all obtainable information, but avoided "listening," and he did not take acoustical analysis into account. Although Seler and Wilson knew each other, they never collaborated, indicating that the objectives followed in each school were never combined. The time was not yet ripe for the combination of individual approaches.

In Altmexikanische Knochenrasseln [Ancient Mexican Bone Rattles] (1889) and Mittelamerikanische Musikinstrumente [Musical Instruments of Middle America] (1899), Seler reviewed all the relevant ethnohistorical, ethnolinguistic, and iconographical sources on pre-Columbian (Aztec) instruments, adding substantial data to Brinton's essay from a decade earlier. Seler was also the first to turn his attention to the music of the Maya, which was widely neglected during this first phase of research.

In 1900 the Mexican archaeologist Leopoldo Batres discovered a large find of musical instruments and miniature votive depictions as part of an offering of the Aztec temple precinct, which was buried under the historic centre of Mexico City (Batres 1902, 47-50). Seler, who undertook field research in Mexico during this time, inspected the excavation and studied the finds. A year later, he published the results in Die Ausgrabungen am Orte des Haupttempels in Mexiko [The Excavations on Site of the Great Temple in Mexico] (1901). Taking this find and its detailed interpretation into consideration, no serious researcher could continue to neglect that the Aztecs and other cultures of the preColumbian Americas had a flourishing music culture that went beyond the wild, shrill, hollow, and diabolic.

In 1902, Batres published a list of the finds and an exact plan of the archaeological context, which 100 years later enabled 
researchers to reconstruct the offering as part of the so-called Western Red Temple, dedicated to the god of music in front of the western stairways of the Great Ballcoart of the temple precinct (Both 1999; Olmedo Vera 2002). In including the excavation plan (Batres) and a descriptive analysis (Seler), the researchers recorded the archaeological context and interpreted the meaning of the musical finds in a new, complementary way. Seler bought many of the objects that he described in his papers, including some finds from the Western Red Temple obtained from Leopoldo Batres, which are now kept in the Ethnological Museum Berlin, while his original drawings of the finds (many unpublished) are housed in the Ibero-American Institute, Berlin (Figs. 8-9). The short handwritten notes accompanying two of the drawings showing ceramic votive depictions of a bone rasp and a turtle shell excavated in the offering of the Western Red Temple demonstrate Seler's expertise regarding Aztec musical instruments: “omichicanartli aus Thon mit der am Condylus befestigten Schnur, an der das Muschelgehäuse hängt, mit der das Instrument gestrichen wird" ["omichicanaztli from ceramics, with the band attached to the condyle, on which the shell hangs with which the instrument is scraped"]; "ayotl, Schildkrötenpanzer, mit dem Hirschgeweih, mit dem die Bauchseite geschlagen wird, und dem Grasring, auf dem die Rückenseite ruht" ["ayotl, turtle shell, with a deer antler with which the ventral side is beaten, and a grass-ring, on which the dorsal side rests']. In Drei Gegenstände aus Mexiko [Three Objects from Mexico], Seler published a tubular flute from Veracruz and a ceramic flower-drum (Seler 1905). Many of these musical objects of the Seler collection were analyzed again one hundred years later (Both 1999; 2002; 2006), including recordings and acoustic studies of some well preserved musical instruments (the recordings are preserved in the Berlin Phonogram Archive, Ethnological Museum Berlin).

In Die religiösen Gesänge der alten Mexikaner [The Religious Chants of the Ancient Mexicans] (1902), Seler published a revised translation of the Aztec chants recorded by Sahagún, and included a comprehensive interpretative section. Seler's integrative way of interpreting ancient musical life using all kinds of sources, was again demonstrated in 1904 in his masterwork Die holzgeschnitzte Pauke von Malinalco und das Zeichen att-tlachinolli [The Wood-Carved 
Drum from Malinalco and the Sign atl-tlacbinolli], in which he discussed the instruments' highly metaphoric symbolism.

Seler and followers, such as Auguste Genin and Herman Beyer, who published some of their works after World War II, came to detailed conclusions on the role of pre-Columbian music and musical instruments, especially among the Aztecs, but they never discussed acoustics. It is an enigma why these renowned researchers avoided listening. There was also no attempt to get in contact with researchers like Wilson/Upham, Holmes, or Mead, suggesting some sort of disinterest in sound, maybe even a kind of fear, which is still common among many conventional archaeologists.

Auguste Genin is among the first scholars to turn their attention to Aztec dance traditions and their music, including living traditions (Genin 1913 and 1922). Herman Beyer followed Seler's method of describing individual artefacts related to music and dance, including large depictions of Aztec musical instruments in stone, further studies on bone rasps, and published iconographic studies, including a study on the meaning of the volutes or sound scrolls frequently depicted in murals and codices (his diverse studies were published subsequently in a compilation entitled Los músicos $y$ sus instrumentos [The musicians and their instruments], see Beyer 1969, 527-563). It is remarkable that many of the interpretations presented by these researchers are still valuable today, although many details which were so carefully discussed remain unrecognized. Except for Mead's study of 1902, not much other research on ancient South American music cultures was carried out in this period. Raoul and Marguerite d'Harcourt, Karl Gustav Izikowitz, Andrés Sas and others began to study the musical instruments of the Inca and previous cultures only after World War I. Among those researchers, who published finds of musical instruments of the American Southwest, were George H. Pepper (1909) and Charles Peabody (1917).

\section{RECORDING THE LIVING PAST}

Franz Boas (1858-1942), Hans Heinrich Brüning (1848-1928), Theodor Koch-Grünberg (1872-1924), Paul Traeger (1867-1933), Wilhelm Kissenberth (1878-1944), Charles Wellington Furlong (1874-1967), Carl Lumholtz (1858-1922), Konrad Theodor Preuss (1869-1938), Robert Lehmann-Nitsche (1872-1938), and others 
are among the first ethnographers who recorded indigenous music of the Americas with the phonograph, which was invented by Thomas Alva Edison in 1877. Wax cylinder recordings of indigenous societies were made from 1893 onwards. However, no attempt was made to research living music traditions together with past music cultures. The researchers focussed on the description and interpretation of current musical traditions, without taking historical dimensions into account. Hornbostel and others studied the recordings, but they avoided comparisons with past musical traditions. From another perspective, only a few cultural anthropologists compared aspects of living cultures, which were generally seen to be "primitive," with pre-Columbian societies.

It is a historiographical enigma that the early ethnomusicologists and organologists did not pay much attention to the remains of the music cultures of the pre-Columbian Americas. In their systematics of musical instruments from 1914, Curt Sachs and Erich Max von Hornbostel did not include all pre-Columbian instrument types, some of which are unique to the world, although the Berlin Phonogram-Archive had close links with the Ethnological Museum Berlin, and the researchers had access to its large pre-Columbian collections. For instance, Hornbostel and Sachs failed to note that the Aztec skull-shaped whistles and other pre-Columbian instruments based on the same constructive principle, in which airflows hit against each other and produce a non-linear sound, are neither fipple flutes, reed instruments, nor trumpets, but belong to a distinct instrument type unclassified so far (Both 2006). Similarly, many globular flute types dominant in pre-Columbian societies were not included. Curt Sachs and other ethnomusicologists turned to ancient music cultures only after World War I.

\section{CONCLUSIONS}

Within four decades between 1880 and 1920 early researchers in the music archaeology of the Americas published a series of studies, which were related to a variety of disciplines. Their works formed the basis of music-archaeological research on preColumbian music cultures, which much later allowed for the formulation of interdisciplinary approaches. While Cresson's initial study Artec Music from 1883 and Brinton's Ancient Nahuatl Poetry from 1890 paved the way, 1898 was certainly the key year for the 
music archaeology of the Americas. In this year, Wilson/Upham and Holmes published their catalogues of pre-Columbian musical instruments, including acoustic data, and discussions on the bone rasp and the origin of string instruments were initiated. These contributions certainly helped to increase awareness of the topic in scholarly circles.

The researchers who published these early studies on preColumbian music cultures followed basically two directions without much interchange. Historians, philologists, and linguists with a strong interest in music interpreted the written and pictographical sources from early Colonial times, and they discussed the role of music and musical instruments in indigenous societies. Cultural anthropologists, namely archaeologists and early ethnographers with a strong interest in musicological problems, approached the topic from another angle. They analyzed the preColumbian sound artefacts from an organological point of view, including acoustic analysis, and they discussed the nature of preColumbian music.

Not surprisingly, much of the research was strongly influenced by current worldviews and the state of knowledge of the time. In some studies diffusionism and Social Darwinism played a role, but many researchers in all fields of research largely avoided West-centric positions, and they undertook analytical and descriptive studies without emphasizing pejorative cultural values.

There were two streams of research with different approaches and objectives: an ethnohistorical-linguistical-iconographical stream, followed by ethnohistorians and cultural anthropologists, and an organological-acoustical stream, followed by some archaeologists and musicologists. Interestingly, protagonists of both streams did not display much cooperation. This virtual barrier was probably related to the researchers' respective objectives, but it also reflects a degree of disinterest in each other's approach. However, many important questions on music in the preColumbian societies were raised and even answered before 1920. It is an enigma of the history of music-archaeological research in the pre-Columbian Americas that many of these early studies were unheard of or ignored in subsequent phases of research. 


\section{BIBLIOGRAPHY}

Batres, L. (1902). Exploraciones arqueológicas en la Calle de las Escalerillas, México. Mexico City: J. Aguila Vera.

Beyer, H. (1916). "Una representación auténtica del uso del omichicahuaztli." Mémoires de la Société Alqate 34: 129_ 136.

(1969). "Los músicos y sus instrumentos." In: Tercer tomo especial y segundo de sus obras homenaje para honrar la memoria de ilustre antropologo Hermann Beyer. El Mexico Antiguo, Tomo XI. Mexico City: Sociedad Alemana Mexicanista: 527-563.

Both, A. A. (1999). Klanggeschichtliche Aspekte der Späten Postklassik Mesoamerikas: Perspektiven der Musikarchäologie. Unpublished MA thesis. Lateinamerika-Institut: Freie Universität Berlin.

(2002). "Aztec Flower-Flutes: The symbolic Organization of Sound in Late Postclassic Mesoamerica." In: Studien zur Musikarchäologie III, ed. E. Hickmann, A. D. Kilmer,

R. Eichmann. Rahden/Westf.: Marie Leidorf: 279-289. (2005). Aerófonos mexicas de las ofrendas del Recinto Sagrado de

Tenochtitlan. PhD thesis, Lateinamerika-Institut, Freie Universität Berlin.

http://www.diss.fu-berlin.de/2007/555/indexe.html. (2006). "Totenkopfpfeifen der Azteken." Baessler-Archiv 53: 43-54.

Brinton, D. G. (1890a). Ancient Nabuatl Poetry. Brinton's Library of Aboriginal American Literature, vol. VII. Philadelphia. (1890b). Rig Veda Americanus: Sacred Songs of the Ancient Mexicans. Brinton's Library of Aboriginal American Literature, vol. VIII. Philadelphia. (1897). "Native American Stringed Musical Instruments." American Antiquarian 19.1: 19-20.

Capitan, L. (1908). "L'Omichicahuaztli mexicain et son ancetre de l'époque du renne en Gaule." In: Verhandlungen des XVI. Internationalen Amerikanisten-Kongreß. Wien: 107-109.

Cresson, H. T. (1883). "Aztec Music." Proceedings of the Academy of Natural Sciences of Philadelphia: 86-94.

Díaz del Castillo, B. (1960) [ms. sixteenth century]. Historia de la conquista de la Nueva España. Introducción y notas de 
Joaquin Ramírez Cabañas (2 vols.). Mexico City: Editorial Porrúa.

Donahue, J. A. (2000). Applying Experimental Archaeology to Ethnomusicology: Recreating an Ancient Maya Friction Drum through Various Lines of Evidence. Paper given at the 65th Annual Meetings of the Society for American Archaeology in Philadelphia, Pennsylvania, April 8, 2000. FAMSI Research Material.

http:/ /www.mayavase.com/frictiondrum.html.

Frobenius, L. (1896). "Ein Teponaztli im Ethnographischen Museum der Universität Basel." Internationales Archiv für Ethnographie 9: 252-253.

Garibay, A. M. K. (1953-1954). Historia de la literatura Nabuatl (2 vols.). Mexico City: Editorial Porrúa.

Genin, A. (1913). "Notes sur les danses, la musique et les chants des Mexicains anciens et modernes." Revue d'Ethnographie et de Sociologie 4: 301-22.

(1922). Notes on the Dances, Music, and Songs of the Ancient and Modern Mexicans. The Smithsonian Report for 1920. Washington: 657-78.

Gudemos, M. (1998). "Flautas óseas precolombinas de la costa central de Perú, ¿organizaciones formales y sonoras preestablecidas?" Baessler Archiv 46: 107-34.

Haly, R. (1986). "Poetics of the Aztecs." New Scholar 10, Voices of the First America: Text and Context in the New World. Santa Barbara: University of California Press: 85-133.

Hawley, E. H. (1898). "Distribution of the Notched Rattle." American Anthropologist 11.11: 344-446.

Holmes, W. H. (1898). Ancient Art of the Province of Chiriqui, Colombia. Annual Report of the Bureau of Ethnology to the Secretary of the Smithsonian, Washington. Washington.

Hornbostel, E. M. and C. Sachs (1914). "Systematik der Musikinstrumente: Ein Versuch." Zeitschrift für Ethnologie 46: $553-590$.

Kollmann, J. (1895). Flöten und Pfeifen aus Alt-Mexiko in der ethnographischen Sammlung der Universität Basel. Herausgegeben von der Ethnographischen Kommission, Band I, Heft 2. Basel/Leipzig. 
Kollmann, J. (1896). "Flöten und Pfeifen aus Alt-Mexiko." In: Adolf Bastian als Fest-Gruss zu seinem 70. Geburtstage. Berlin: 559-74.

Lumholtz, C., and A. Hrdlička (1898). "Marked Human Bones from a Pre-Historic Tarasco Indian Burial Place in the State of Michoacan, Mexico." Bulletin of the American Museum of Natural History 10: 61-85.

MacCurdy, G. G. (1911). A Study in Chiriquian Antiquities. Memoirs of the Connecticut Academy of Arts and Sciences, vol. III. New Haven, Connecticut: Yale University Press.

Mason, O. T. (1897). "Geographical Distribution of the Musical Bow." American Anthropologist 10: 377-80.

(1898). "Discussion and Correspondence." Science 8.194: 371.

Mead, C. W. (1903). The Musical Instruments of the Incas: A Guide Leaflet to the Collection on Exbibition in the American Museum of Natural History. American Museum of Natural History, supplement to the American Museum Journal, vol. 3.4. New York.

Mendoza, V. T. (1956). Panorama de la música tradicional de México. Mexico City: Imprenta Universitaria.

Nowotny, K. A. (1956). "Die Notation des 'Tono' in den aztekischen Cantares." Baessler-Archiv 4.2: 185-89.

Peabody, C. (1917). "A Prehistoric Wind-Instrument from Pecos, New Mexico." American Anthropologist 19.1: 30-33.

Pepper, G. H. (1909). "The Exploration of a Burial-Room in Pueblo Bonito, New Mexico." In: Putnam Anniversary Volume, Anthropological Essays. New York: 196-251.

Pereira, G. (2005). "The Utilization of Grooved Human Bones: A Reanalysis of Artificially Modified Human Bones Excavated by Carl Lumholtz at Zacapu, Michoacán, Mexico." Latin American Antiquity 16.3: 293-312.

Pigorini, L. (1885). Gli antichi oggetti messicani incrostati di mosaico esistenti nel. Museo preistorico ed etnografico di Roma. Rome: Memorie Reale Accad. dei Lincei.

Sahagún, F. B. de (1950-1982) [ms. sixteenth century]. The Florentine Codex (12 vols.). Translated from the Aztec into English by Arthur J. O. Anderson and Charles E. Dibble. Santa Fe: The School of American Research and the University of Utah. 
Sapper, C. (1897). Das nördliche Mittel-Amerika nebst einem Ausflug nach dem Hocbland von Anabuac: Reisen und Studien aus den Jabren 1888 bis 1895. Braunschweig: Friedrich Vieweg \& Sohn.

Saville, M. H. (1897). "A Primitive Maya Musical Instrument." American Anthropologist 10.8: 272-73. (1898). "The Musical Bow in Ancient Mexico." American Anthropologist 11.9: 280-84.

Seler, Eduard (1898). "Altmexikanische Knochenrasseln." Globus 74.6: 85-93.

(1899). "Mittelamerikanische Musikinstrumente." Globus, Band 76, Nr. 7 (August 1899), 109-12. (1901). Die Ausgrabungen am Orte des Haupttempels in Mexiko.

Mitteilungen der Anthropologischen Gesellschaft in Wien, Band 31, 113-37. Wien.

(1902). Die religiösen Gesänge der alten Mexikaner. Gesammelte Abhandlungen zur Amerikanischen Sprach- und Alterthumskunde, Band 2, 964-1108. Berlin: A. Asher \& Co.

(1904). Die holzgeschnitzte Pauke von Malinalco und das Zeichen atl-tlachinolli. Mitteilungen der Anthropologischen Gesellschaft in Wien, Band 34, 222-74. Wien.

(1905). "Drei Gegenstände aus Mexiko." Zeitschrift für Ethnologie 37: 441-44.

Squier, G. E. (1877). Peru: Incidents of Travel and Exploration in the Land of the Incas. New York: Henry Holt \& Co.

(1883). Peru: Reise- und Forschungserlebnisse in dem Lande der Incas. Leipzig: Max Spohr.

Starr, F. (1898). "Notched Bones from Mexico." Proceedings of the Davenport Academy of Sciences 7 (1897-1899): 101-107.

Wead, C. K. (1902). Contribution to the History of Musical Scales. From the Report of the United States National Museum for 1900. Smithsonian Institution, United States National Museum. Washington: Government Printing Office: 417-62.

Wilson, T. (1898). Prehistoric Art: Or the Origin of Art as Manifested in the Works of Prehistoric Man. From the Report of the United States National Museum for 1896, with seventyfour plates. Smithsonian Institution, United States National Museum. Washington: Government Printing Office: 325-664. 
Ziehm, E. (1976). Nahua-Texte aus San Pedro Jicora in Durango, Dritter Teil: Gebete und Gesänge. Quellenwerke zur alten Geschichte Amerikas, vol. XI. Berlin: Gebrüder Mann Verlag. 


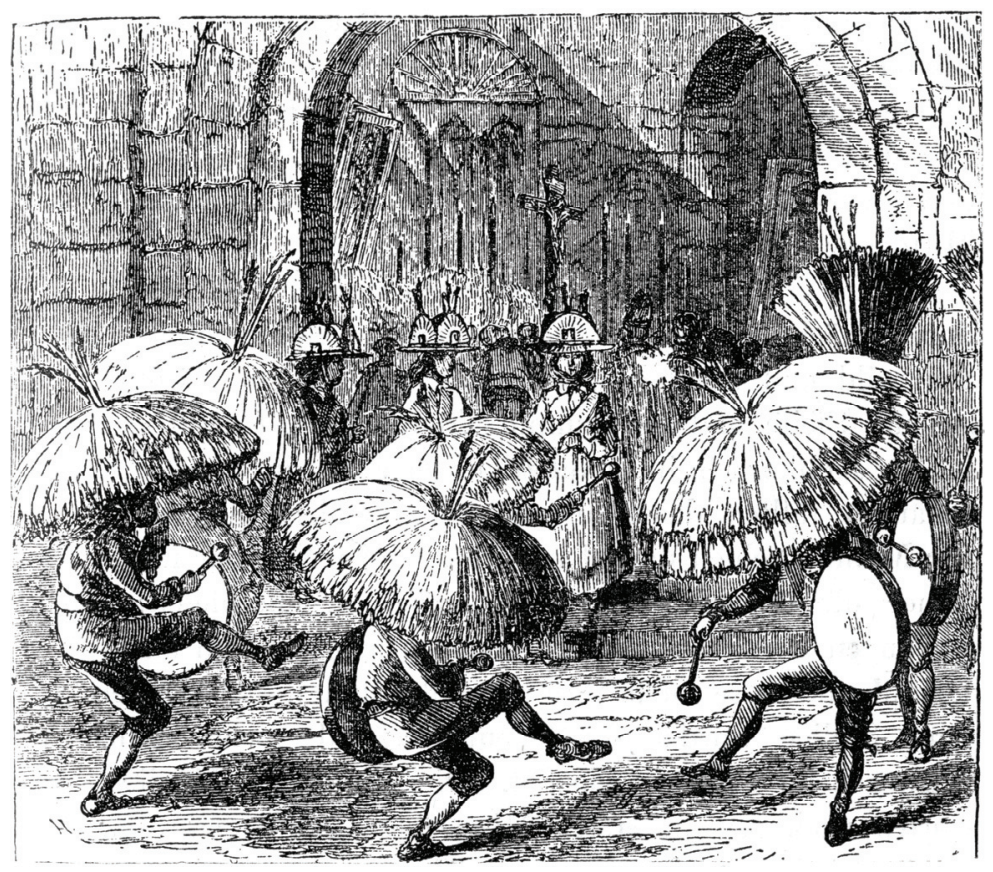

Fig. 1. Drum and panpipe players celebrating the chuño, a freeze-dried potatoes product, in front of a church in the Aymara region of the Bolivian highlands near Tiahuanaco (Squier 1883, 377). 


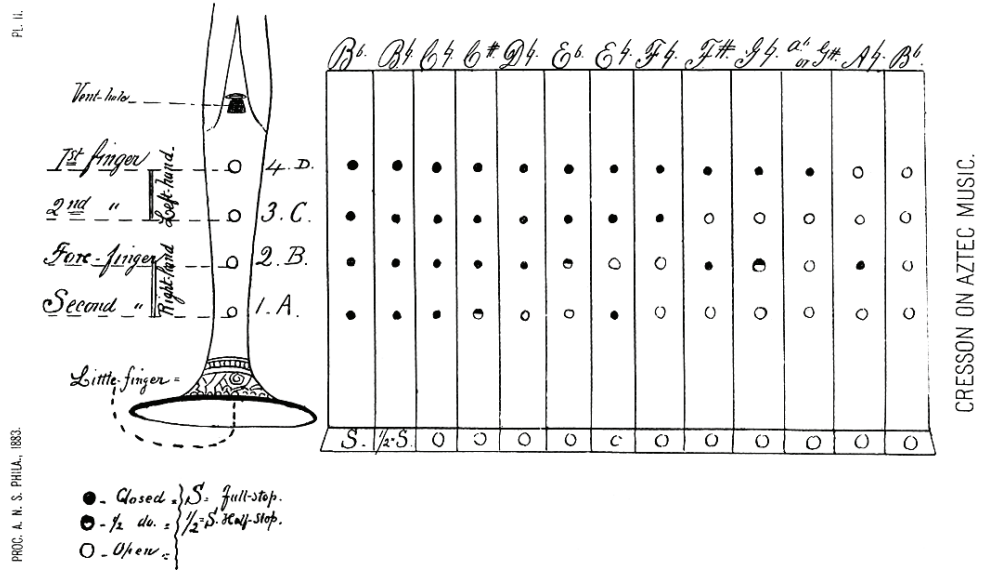

Fig. 2. Notes per finger-combination obtained on an Aztec flower-flute

(Cresson 1883, Pl. II).

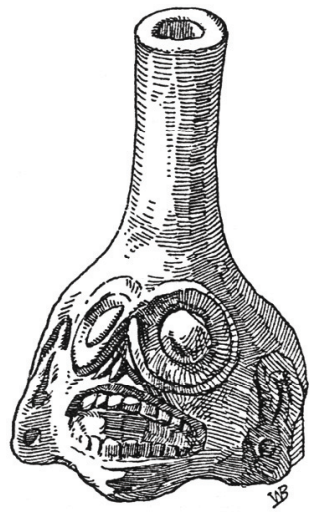

Fig. 3. Aztec skull-shaped whistle (Kollmann 1895, 68, Fig. 11). 

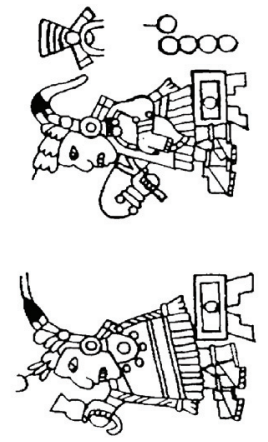

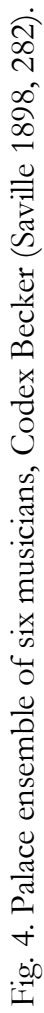

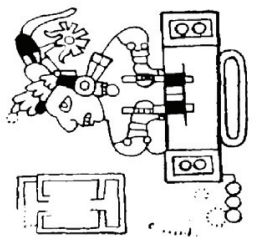




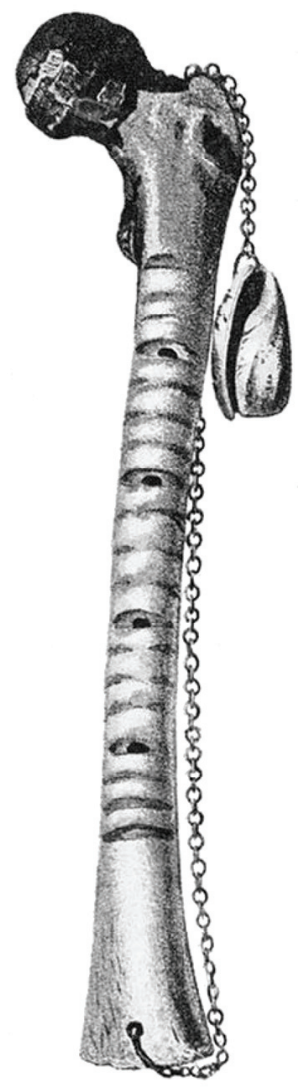

Fig. 5. Bone rasp with shell scraper (Pigorini 1885). 
The body of the instrument is painted dark brown and ornamented near the lower end with three bands in red. The bell (or flaring end) is not painted, but is ornamented in relief. The painted portion is highly polished. With normal force in blow. ing the following tones can be made; fingering as indicated in the accompanying scale:

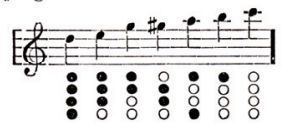

The notes $c, b, g$, can also be obtained by using the following method:

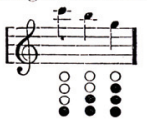

With increased force the following notes are given:

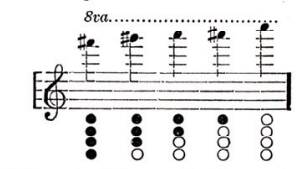

The note $\mathrm{F} \#$ can also be made by
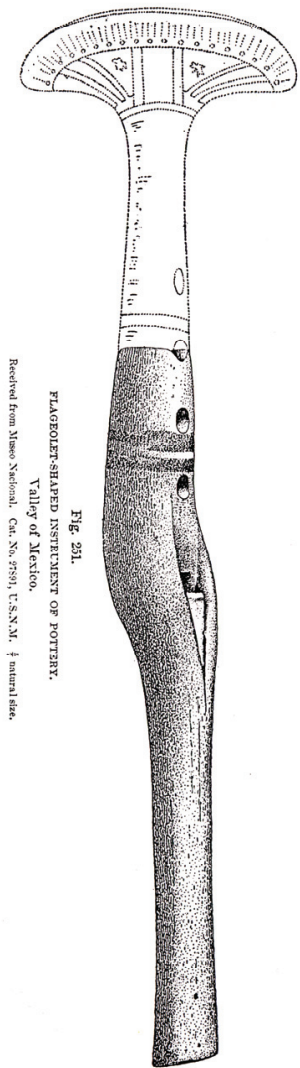

It hardly seems possible that these upper notes could or would be used to any great extent as the force required to obtain them makes it almost a physical impossibility.

The Poinsett collection in the $\mathrm{Mu}$. seum of the Academy of Natural Sciences, Philadelphia, contains a

Fig. 6. Page of Wilson's Prehistoric Art $(1898,605)$, showing notes per finger-combination obtained on an Aztec flower-flute. 

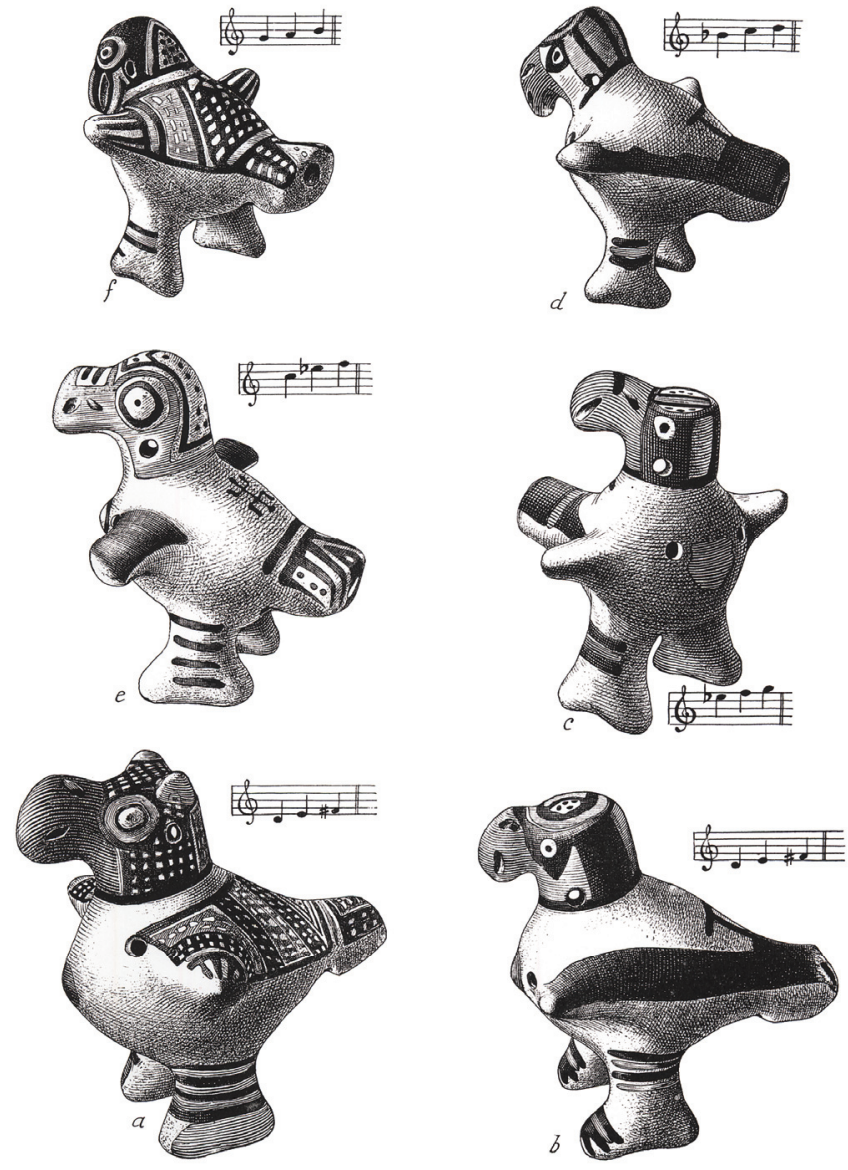

Fig. 7. Globular flutes from Chiriquí, Panama (MacCurdy 1911, Pl. XLVII). 


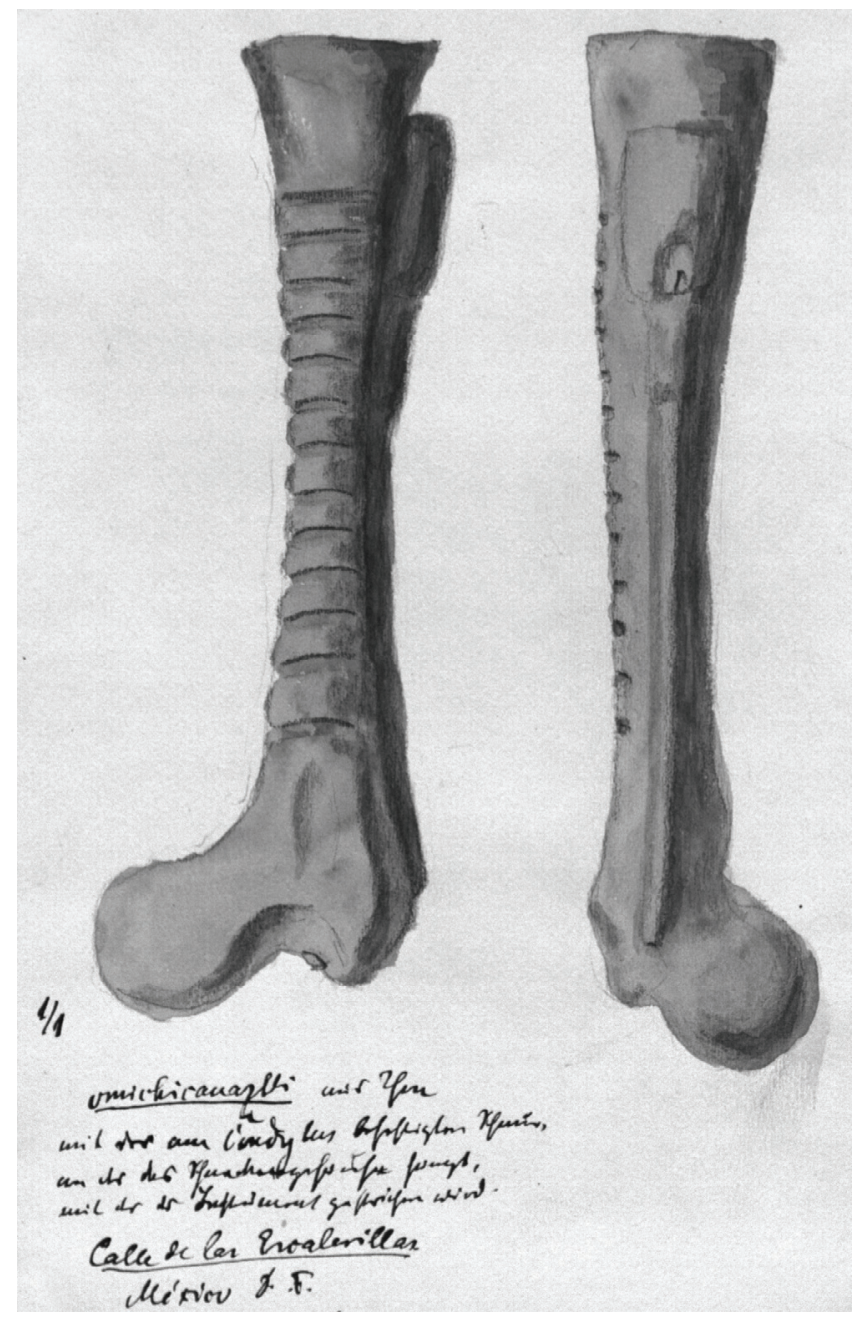

Fig 8. Ceramic votive depiction of a bone rasp with shell. Drawing by Eduard Seler.

Courtesy: Ibero Amerikanisches Institut, Preussischer Kulturbesitz. 


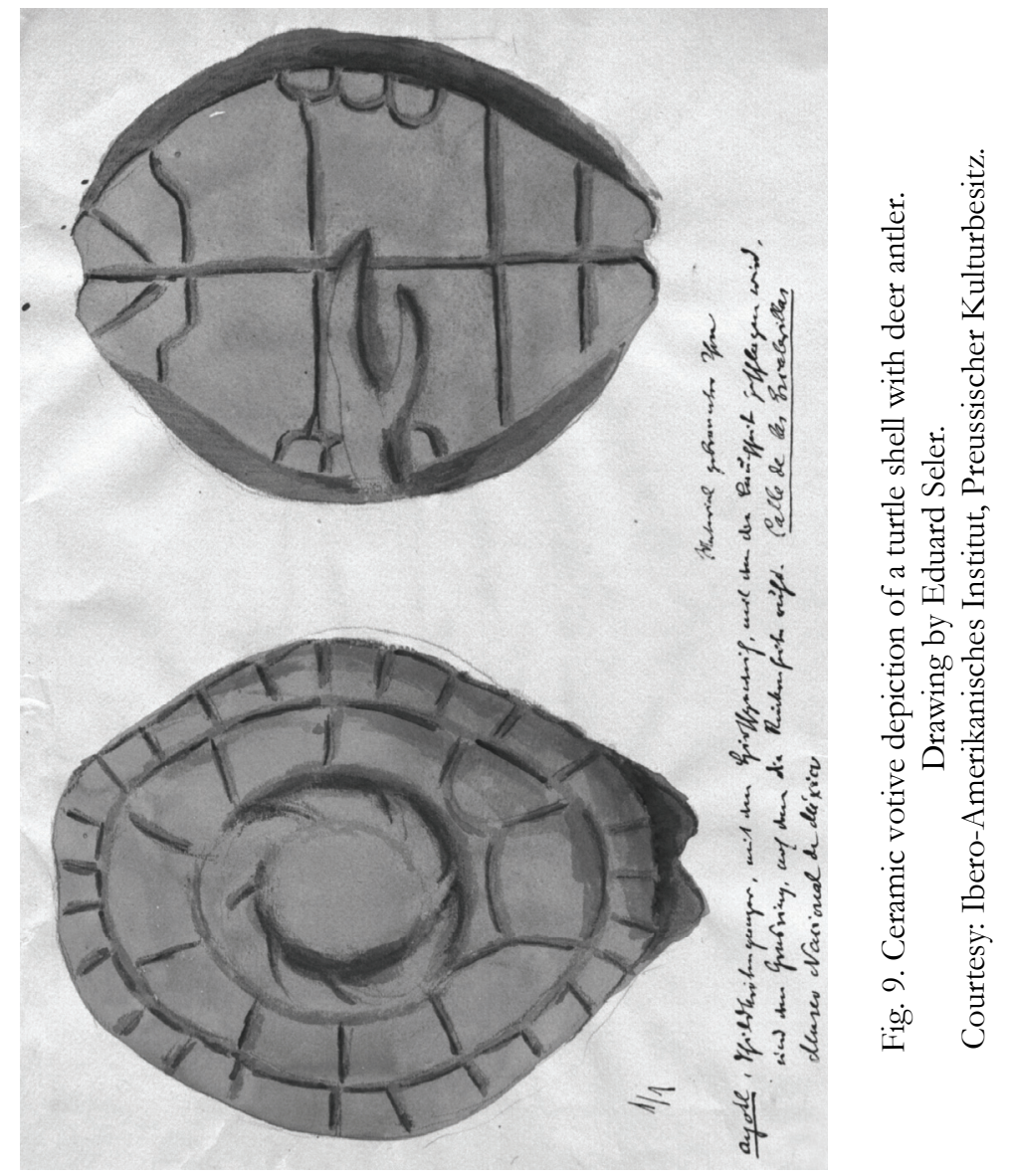




\title{
ANTIQUARIANS, ARCHAEOLOGISTS AND MUSIC IN NINETEENTH CENTURY LONDON: \\ EARLY CONVERSATIONS IN MUSIC'S PREHISTORY
}

\author{
GRAEME LAWSON
}

Recent bibliographical research into the early history of music-archaeological reporting in Great Britain and Ireland has revealed a wealth of material which, although rarely cited today, nevertheless contains much of interest to the modern music archaeologist. Besides descriptions of early discoveries there is evidence that dialogues of a musicarchaeological kind were already taking place both in the literature and amongst antiquaries and archaeologists more than one bundred and fifty years ago. One flurry of activity is evidenced in the proceedings of the British Archaeological Association, formed in London in 1843. Already in 1846, in the first volume of its Journal, music, instruments and sound-tools are prominently represented, and for about the next ten to fifteen years members deliver a series of synthetical papers as well as numerous reports of new musical finds. Many of the objects and documents remain in museum collections today; yet the authors themselves are mostly forgotten. The writer argues that to ensure a secure future, music archaeology, like any modern discipline, must have a clear understanding of its own past, both recent and remote, and draws attention to the urgent need-and plentiful opportunities—for further historiographical study. 
Over the last two or three years, whilst pursuing various scientific projects in the fields of music archaeology and archaeoacoustics, I have also been conducting exercises in what may be called "cold case review": revisiting bibliographical and other documentary evidence for musical finds - or to be precise, antiquarian and early archaeological finds of musical instruments-which came to light a hundred or more years ago. Many of these finds are still of great interest and value today, where their whereabouts are known to us: but alas, in several important cases they are not. Such disappearances represent not only a loss to science but at the same time a mystery and a challenge. They include, for example, part of the wooden frame of a small medieval harp from County Antrim in Northern Ireland, of which only a published drawing now survives (Knowles 1897, Fig. 1) and a complete sixth century lyre from a waterlogged grave in southern Germany. The harp (Fig. 1 here) is still without parallel, either in Ireland or anywhere else in these islands: there are many medieval pictures, of course, and some written accounts, but excavation has yielded only a scatter of stray fitments made from more resilient materials, such as bone or metal. And we still have no idea what happened to the original object. The lyre (Fig. 2) did rather better, surviving two world wars, only to succumb in 1945 through the negligence, or worse, of victorious Allied troops. Its sole remaining photograph shows tantalising details of construction, material composition and even - to the eye of faith-surface patination (Veeck 1931, Plate 4 B no. 9).

Of course, we would dearly love to find parts - any parts - of these long-lost instruments, however mutilated they may have been; and it would be wonderful to have even small fragments to put under a microscope. But an acceptable second-best would be to know at least a little more about what really happened and to locate any documentation and images that might shed further light upon their forms and original conditions. I have been conducting one such investigation in collaboration with Dr Peter Holmes, reviewing the early history of antiquarian activity in Great Britain and Ireland, initially for the bearing it might have on the curious matter of the Tattershall "Carnyx." This was a near-complete bronze trumpet of the Iron Age, found in the late eighteenth century while dredging the bed of the River Witham in Lincolnshire. Not long afterwards it came into the possession of Lincolnshire land-owner Sir Joseph Banks, the eminent scientist 
and antiquary, newly returned from Captain James Cook's Endeavour expedition to the South Seas; and Banks committed it to the care of Dr George Pearson, Fellow of the Royal Society, for metallurgical analysis. No further sighting of it has ever been verified. Accusing fingers have lately been pointed at Pearson and his methods. There is, however, much new information to be gleaned from a close re-examination of his report (Pearson 1796), and especially from unpublished documents surviving at the Royal Society and elsewhere. These include, in Lincoln Public Library, a remarkably detailed contemporary watercolour painting, drawn carefully to scale at Joseph Banks' own expense by the illustrator John Claude Nattes. This later formed the model for a fine engraving by the Society's lithographer James Basire (Fig. 3). Detailed publication of our conclusions is now in hand (Lawson \& Holmes forthcoming). From the documents emerges a fresh appreciation of Banks' aims and Pearson's methods, as well as new perspectives for our modern interpretation of Classical texts and of some recent archaeological discoveries (for the most dramatic of which see Maniquet 2008).

Investigations like these have taken us the length and breadth of nineteenth and early twentieth century Europe, a period in which antiquarian collection and "cabinets" (private museums of curiosities) gradually gave way to forms of investigation and of conservation which are recognizable as the basis of modern archaeology and museology. Ultimately the new, more "scientific" approaches to investigative fieldwork have their British origins earlier in the eighteenth century, in attempts by the Rev. Dr William Stukeley and his associates to compensate in the field for the meagreness of the records left by the Classical authors of life in Roman and earlier (prehistoric) Britain. Stukeley (1687-1765), sometime fellow of Corpus Christi College in Cambridge, later rector of Stamford in Lincolnshire and finally at Queen Square in central London, played a leading role in the work of our most senior antiquarian associations: the Spalding Gentlemen's Club in Lincolnshire and the Society of Antiquaries of London. Although spoiled a little for us by a romantic obsession which led him to attribute so much of what he found to "the Druids," his scientific insights were quite remarkable. He was the first, for example, to recognise those modern staples of aerial photographic survey: crop-marks - changes in the colour of ripening wheat which reveal 
otherwise hidden variations in the depth of the soil beneath; for example, where ancient ditches or pits have dug deeper into the harder ground below. In his Itinerarium Curiosum of 1724, Stukeley describes a circular alignment of green blotches in a ripening cornfield at the foot of a hill near Cambridge, adding: "The people say, let the year come as it will, this place is ever visible, and it has been so ever since the memory of man; and they fancy the fairies dancing there causes the appearance" (Daniel 1967, 45). This is an astute piece of observation. His appeal for more research in the field was taken up by other investigators including, in the midnineteenth century, Charles Roach Smith. And it was around that time that the term "archaeology" came properly into vogue. Under its banner, investigators (including Roach Smith himself) set up the first real archaeological associations: the Archaeological Institute of Great Britain and Ireland, and the British Archaeological Association.

Archaeology in the 1840s and 1850s was not yet archaeology in our often restrictive modern sense, dominated by field survey and excavation, but a much more wide-ranging and inclusive exploration of the ancient material record. Nevertheless, fieldwork was already very much in the ascendancy, and it is therefore fascinating when we inspect the accounts of their meetings and their earliest publications to see how much space they are still prepared to devote to music-related topics and music-related finds.

Today we are sometimes tempted to think of our new archaeological approaches to music and acoustics as a first-time enterprise, and indeed in certain technical, investigative and interpretive respects it is highly innovative-but that is by no means the whole story. The earliest antiquaries had long thought of music as lying comfortably within their domain. The Society of Antiquaries of London, for example, had felt able to include musical topics in the very first volumes of their Archaeologia (1770-). So now did the new archaeologists, and there is much in their publications that must interest the modern music archaeologist. Besides descriptions and illustrations of musicrelated finds and monuments, patterns are also revealed of writing and reporting, showing that dialogues of a music-archaeological kind were already taking place in the literature, in antiquarian society and amongst archaeologists, more than one hundred and fifty years ago. The most remarkable flurry of activity is evidenced 
in the proceedings of the British Archaeological Association itself. Formed in London in 1843, its journals, the Archaeological Journal and the Journal of the British Archaeological Association, first appeared in 1845 and 1846 respectively (Fig. 4). Both journals and society still flourish today, the Association publishing JBAA and the Archaeological Institute (after an early schism, and now the Royal Archaeological Institute) continuing the $A r c h$. J. Already in the very first volume of $J B A A$ music is prominently represented; and for about the next ten to fifteen years members deliver or communicate a series of synthetical papers on the subject as well as numerous short reports of new musical and sound-related finds, images and historical texts. Bells, pipes, harps, horns and trumpets are all described, and even architectural structures such as belltowers. Many of the objects remain today in museum collections; yet paradoxically the authors themselves, and their contributions, are now almost entirely forgotten. How such enthusiasm came to archaeology in the first place, and how it lost its way, makes a fascinating puzzle.

I rather suspect that the initial enthusiasm owed its beginnings as much to the curiosity of the founder members as it did to any systematic investigations which they may already have been making. It seems significant that the first of all the musical contributions, in that very first volume of $J B A A$, should be not a specially authored paper but simply a reprint, albeit a substantial one: an anonymous, presumably editorial, English paraphrase, with original woodcuts, of E. de Coussemaker's recent contribution to Adolphe Didron's new Paris monthly Annales Archéologiques (Figs. 5 $\& 6)$. There is nothing in the $J B A A$ editorial to say who thought this a good idea; but clearly someone did. Someone had evidently taken the trouble to obtain Didron's original plates, and his permission to use them. And in the following years there would be no lack of eagerness at the Association for discussing other musical matters. No doubt people were influenced by music's increasing prominence in Didron's Parisian circle, for already in his first volume Didron was promising future articles on the music of the Gothic age by "mes amis...MM. Danjou [de Paris], [Louis] Fanart [de Reims] et [Eugène] de Coussemaker [de Bergues]" (Didron 1844). At any rate, elsewhere in that same first volume of $J B A A$ we see a letter from a Mr T. F. Dukes of Shropshire (in the Proceedings of the meeting of 28 May 1845) offering an account of 
traditional Easter celebrations in that county, which included processions to the accompaniment of horns and acclamations. This can hardly be just coincidence, and indeed inspection of subsequent Proceedings reveals a great deal more of similar sort. In $J B A A$ II (1847), alongside a second de Coussemaker article, we are presented with a discussion of a sixteenth century bell by the Rev. A. B. Hutchings (pp. 184-6); a drawing by a Mr Lindsay, of Cork, Ireland, of the inscription on a bell found in Bristol (p. 199); an image of a hunting horn figuring in an account by Thomas Bateman of the designs of sepulchral slabs in Derbyshire (p. 258); a description and drawing by Mr Wake Smart of a decorated Norman font found buried under the floor of a church in Devon, showing (Fig. 7) hunting horns, a harper and an acrobat (pp. 271272); and a report of a small bronze Roman bell from London, exhibited by a Mr Chaffers (p. 340).

The person who, one suspects, may well have been doing most to encourage such musical reporting amongst the early members was a man called Henry Syer Cuming, of Southwark in London. Having inherited the collecting passion from his father Richard, he became an equally avid and eclectic (not to say eccentric) gatherer of anything interesting from the past or from "primitive" or otherwise exotic cultures around the world. $\mathrm{He}$ bought anything and everything that came onto the market and caught his fancy, including especially items neglected or disregarded by other collectors. A particular archaeological focus was finds from London and the River Thames, as well as antiquities brought back from the Mediterranean and Egypt. ${ }^{1}$ But he also loved comparing materials with other collectors. At the Association's meeting on 12 April 1848 he read, or at least formally submitted, an article on the ancient practice of "couvre-feu" and the ringing of curfew bells. He had already put it "on the table" once, at the February meeting. A year later he felt emboldened to submit another under the (to our eyes, curious) title of "On phonic horns"

1 The objects today form the core collections of the Cuming Museum, for whose establishment in 1906 he would leave the London Borough of Southwark a substantial sum of money (eight thousand pounds) in his will (Bryn Hyacinth, personal communication). 
(Fig. 8). By this it seems he meant ancient horns and trumpets of all kinds, both archaeological and traditional. The pieces which he cites include the Irish Bronze Age horns, the property of fellow collectors such as Dillon and Crofton Croker, which he attempts to relate to preserved historic instruments, to surviving folk traditions and to descriptions by ancient writers. But he duly extends his theme still wider, into a review of almost any ancient, historical or "primitive" instrument that could be blown. It is an impressive tour de force, and no doubt his enthusiasm was infectious. In the following year (1851) others joined the fray, both in the proceedings and with synthetical papers of their own. Besides an account (within a report by Llewellyn Jewitt) of a find of a small globular bell from Headington near Oxford (Fig. 9), there is a significant review article by Charles Egan on the history and early form of the harp in Britain and Ireland (Figs. 10 \& 11).

Jewitt's account helped stimulate reporting of further occasional finds, too numerous to detail here, and the 1858 volume included two fuller musical treatments: one by the Rev. Beale Poste on the musical iconography of some medieval stained glass from Norwich, showing "minstrels" and their instruments (Fig. 12), and the other by J. Lambert Esq. "of the Academy of St Cecilia" describing an important medieval music manuscript from Salisbury, the Sarum Tonale. This was becoming almost as wide-ranging as music archaeology is today.

In $1877 \mathrm{JB} A A$ published a lengthy etymological treatment by J. S. Phené of the word karnyx, a term used by Greek authors of certain barbarian trumpets and which we now attach to a type of Iron Age straight trumpet. But although the article makes a useful contribution, for its time, Phené gives no explanation as to why he is offering it. There must have been a reason, or an occasion, one would suppose, but the circumstances are not yet clear. It is tempting to speculate that it might be in some way connected with the lost Tattershall find, which had received a further mention by Albert Way in the Institute's proceedings of 1861. But we simply do not know. In truth, a lot of other things remain unclear too, and much work remains to be done, especially to flesh out the interpersonal and cross-disciplinary dynamics - who was talking or writing to whom, and in what context. It is unclear, for example, how far the early discussions may have contributed to, and benefitted from, musicological approaches to music's remote 
antiquity at around the same time, in the way that Banks and Pearson had presumably conferred with music historians such as Dr Charles Burney in the 1790s, or the way Didron was now involving de Coussemaker and others in France and Belgium. Was there indeed any meaningful correspondence between the Association and de Coussemaker? And what of other figures closer to hand, on the London musical scene? This all cries out for further investigation.

One of the most famous and influential musicological publications in the later part of the period was Carl Engel's The Music of the Most Ancient Nations; particularly of the Assyrians, Egyptians, and Hebrews; with special reference to recent discoveries in Western Asia and in Egypt (Figs. 13-14). It was published by John Murray in 1864. Engel's changing viewpoint and his growing interest both in world musics and in their distant past can be charted through his output: in 1853 The Pianist's Handbook, in 1854 his Reflections on Cburch Music, then in 1866, after a gap of twelve years, An Introduction to the Study of National Music (by which again he means the musical traditions of different nations). Then in 1879 came his systematic, organological study A Descriptive Catalogue of the Musical Instruments in the South Kensington Museum.

Undoubtedly Engel was influenced in this journey by the long musicological tradition of discussing musical origins, as we might suppose the BAA to have been. Indeed, as Bennett Zon has so recently shown, he was an active contributor to the work of the Anthropological Institute of Great Britain and Ireland, which had been established in 1871 by reuniting two older societies, the Anthropological Society and the Ethnographical Society of London (Zon 2007, 136). In his new-found role as anthropologist he soon came to reject many long-cherished notions of music's origins, particularly those which discriminated teleologically between its "primitive/savage" (Eastern) and "civilized" (Western) expressions. A particular target would be Herbert Spencer's controversial essay 'The origin and Function of Music' (1857; Zon 2007, 145). Unlike Spencer he was a passionate advocate of modern approaches and of new ways of thinking. But it is not yet clear what, if any, personal contribution he might have made to archaeological discourse, either generally or, more specifically, to our flurry of archaeological interest at the Association. Perhaps he did not, directly. At any rate $\mathrm{I}$ have so far found no record of any 
contribution, neither do his citations shed further light. In the preface to his second edition of 1870 (Engel 1864) Engel cites Henri Fétis' Histoire Generale de la Musique, elsewhere (pp. 83-5) somewhat dismissively, his 1837 Biographie Universelle des Musiciens and other publications, and Sir John Gardner Wilkinson's The Manner and Customs of the Ancient Egyptians. In the text he acknowledges the earlier histories of music by Forkel (Geschichte der Musik), Dr Charles Burney and Sir John Hawkins, individual studies such as Arthur Bedford's 1706 The Temple Musick of Jerusalem (p. 105), and reports of finds from the recent antiquarian fieldwork of Austen Henry Layard, Loftus, and Henry Rawlinson. And like Henry Cuming he came increasingly to use world musics as his preferred philosophical starting point. Amongst his earliest citations are (p. 150) von Kiesewetter's Die Musik der Araber (Leipzig 1842) and (p. 151) Capt. Augustus Willard's A Treatise on the Music of Hindoostan (Calcutta 1834). Can we detect in Engel's Chapter One a vague echo (2nd ed., pp. 10-11) of Henry Cuming's "On phonic horns"? If so it is oblique and without acknowledgement. And, on the contrary, he sometimes adopts a somewhat hostile, almost anti-archaeological stance, challenging (2nd ed., pp. 8-9) what he states to be the usual "notion that, in order to trace the art of music from its most primitive state and to observe its gradual development, we must commence our enquiries by penetrating the most remote periods." He goes on to explain that "A clear idea of the gradual development of the art of music, from its most primitive condition to that degree of perfection in which it at present exists among ourselves, may best be obtained by examining the music of contemporary nations in different stages of civilisation."

Other citations include (on the Assyrian harps, though dismissing the poor quality of the illustration) Bunting's General Collection of the Ancient Music of Ireland Vol. I, which, Engel says, "is prefaced by an elaborate "Historical and Critical Dissertation on the Harp." Also, incompletely (p. 163), works on "Hindoo music" by Sir William Jones and Sir W. Ouseley; and (p. 170) H. M. Williams' 1814 translation of Alexander von Humboldt's (undated) Researches concerning the Institutions and Monuments of the Ancient Inbabitants of America; (p. 172) J. C. Walker's Historical Memoires of the Irish Bards (London 1786); (p. 173) Michael Conran's The National Music of Ireland (Dublin 1846, elsewhere “1848”); (p. 175) G. W. Fink’s Erste 
Wanderung der ältesten Tonkunst (Essen 1831); (p. 179) Max Müller's Lectures on the Science of Language (London 1862)... and so on. But nowhere is there any acknowledgement of even the existence of the BAA.

This first survey has been fascinating, yet so far inconclusive, and the principal questions still remain: what, if any, impact might the musical activity of the early British Archaeological Association have had on the onward development of ideas about music's antiquity and origins? How far had it ever drawn on, and how far in its turn had it ever informed, the contemporary enquiries of other disciplines? Finally, in its own terms, why do the conversations seem to have petered out? Was it that members simply lost interest in music, or lost heart in the process, or were the interest and the activity taken up by some other group, in some other milieu? In other words, did it expire or was it eclipsed, or subsumed? From the BAA's perspective it does look rather like extinction. One may wonder whether an element in this could be a failure of wider engagement, even within archaeology. The illustrations of Bronze and Iron Age horns in Plate XIII of John M. Kemble's longdelayed Horae Ferales or Studies in the Archaeology of the Northern Nations, posthumously published in 1863 by R. G. Latham and Augustus Franks, may well lie behind Albert Way's musical reminiscence in the Arch. $J 18$ (1861, 150), but it is so far only a tenuous connexion. Charles Roach Smith's only significant musical foray, the report and illustration of a possible Roman tuba (preserved in Saumur Museum) in Volume IV of his Collectanea Antiqua (1857, Plate IX) is not picked up anywhere in $J B A A$. It seems that as archaeology and prehistory evolved, musical materials and ideas simply failed to maintain their place amongst them. Perhaps the finds were still too disparate and the picture they painted too inchoate to seem apt to the directions archaeology was now taking. Elsewhere and more generally, I think, the initiative would remain with musicology, which perhaps in reality had always felt itself to be the legitimate home for such interests. In consequence the subject would tend increasingly towards what might be described as "archaeomusicology," rather than a true music archaeology: music-led, dependent on texts and images, largely unaffected by archaeological finds of actual instruments, and becoming increasingly divorced from the archaeological process. To be sure, it would not be until the twentieth century that material 
remains would again begin to occupy centre stage in the evaluation of ancient musical practice and begin to impact once more upon archaeological thinking through the archaeological literature. Even now the approach has its doubters and detractors.

Perhaps it would be unfair to give an impression that, in the end and after all, all the efforts of Henry Cuming and his friends did not amount to very much: that their aspirations were premature and came to a dead end. We simply do not know. But even if it were true it might still hold some lessons for us today, however different our present circumstances might seem. It is true that the current growth of archaeoacoustics — of interest in the acoustic character of landscapes and monuments - is broadening our base within archaeology, while at the same time there is a growing archaeological appreciation of music's potential role within human evolution. It is true also that music archaeology today gains credibility and relevance from its now considerable accumulation of excavated materials, beyond the wildest dreams of Henry Cuming and his friends. Still, its future hangs, as ever, in the balance, and for it to secure a permanent place within archaeology - the discipline which, after all, promises most to expand its evidence-it must surely both evolve and interact. It must continue to establish its archaeological credentials, as a study of important, even quintessential, human behaviours and perceptions. And it must establish and rehearse its links with its own past. Certainly a question mark would hang over the future of any discipline (as music archaeology aspires to be) which had yet to form a clear sense of its own historical development, and of its roots. With this in mind a new archaeological initiative in Cambridge is setting out to generate a series of publications, initially electronic, which will resurrect some of this literature systematically in facsimile. We are calling it Antiquarian Approaches to Ancient Musics. Volume One, now nearing publication, will cover the period, people and organizations described in this article. Meanwhile a larger programme, affording the early pioneers of music archaeology a more in-depth biographical treatment, is being undertaken in collaboration with Cajsa S. Lund and Gjermund Kolltveit. Both projects are revealing their source materials to be rich, and full of surprises. 


\section{Key Periodicals}

Annales Archéologiques. Paris: Bureau des Annales Archéologiques, 1844

Archaeologia (or, Miscellaneous Tracts relating to Antiquity). London: the Society of Antiquaries, 1770

Archaeological Journal, The (Arch. J). London: Central Committee of the British Archaeological Association 1845-6 (I-II); London: Central Committee of the Archaeological Institute 1846- (III-)

Journal of the British Archaeological Association (JBAA). London: the British Archaeological Association, 1846-

\section{BIBLIOGRAPHY}

Beale Poste, the Rev. See Poste.

Cuming, H. S. (1850). "On Phonic Horns." JBAA V: 119-132.

de Coussemaker, E. (1846). "On the Musical Instruments of the Middle Ages." JBAA I: 291-7 \& II (1847), 221-9. (1845-8). "[Essais sur] Les Instruments de Musique au Moyen Age." In: Annales Archéologiques. [In an editorial note in volume VIII (1848) Didron cites de Coussemaker's previous contributions as: III: 76,142 , 260; IV: 25, 94; VI: 315; VII: 92, 157, 244, 325. The 1848 piece is VIII: 242-50. Didron introduces de Coussemaker in Volume I as "Eugène de Coussemaker," thereafter as "E. de Coussemaker"; but unless he is different from the medievalist and musicologist Edmond de Coussemaker, or more fully, Charles Edmond Henri de Coussemaker (1805-1876), "Eugène" must be an error on Didron's part.] (1848). 'Essai sur] Les Instruments de Musique au Moyen Age: Reubèbe-rebec.' In: Annales Archéologiques VIII: 242-250. Free to download at: <http://www.archive. org/stream/annalesarcholog24didrgoog\#page/n319/m ode/1up $>$ Note the URL's misspelling $<\ldots$...rcholog...>.]

Daniel, G. E. (1967). The Origins and Growth of Archaeology. Harmondsworth: Penguin Books (Pelican imprint). 
Didron, A. N. (1844). "La Musique au Moyen Age." In: Annales Archéologiques I: 54-62. Free to download at: <http:// www.archive.org/stream/annalesarcholog14didrgoog\# page/n89/mode/1up> [Note the URL's misspelling $<\ldots$..archolog...>.]

Egan, C. (1851). "On the Antiquity and Primitive form of our National Instrument, the Harp." JBAA VI: 103-116 \& pls. XI-XII.

Engel, C. (1864). The Music of the Most Ancient Nations; particularly of the Assyrians, Egyptians, and Hebrews; with special reference to recent discoveries in Western Asia and in Egypt. London: John Murray (2nd edition 1870).

Jewitt, Ll. (1851). "On Roman Remains, recently discovered at Headington, near Oxford." JBAA VI: 52-67.

Knowles, W. J. (1897). "Portion of a harp and other objects found in the crannog of Carncoagh, Co. Antrim." Journal of the Royal Society of Antiquaries of Ireland Series V, vol. VII: 114-15.

Lambert, J. (1859). “On the Sarum Tonale MS.” JBAA XV: 302-5.

Lawson, G. \& Holmes, P. (forthcoming). "Eighteenth-century science on trial: Joseph Banks, George Pearson and the fate of the Tattershall carnyx."

Maniquet, C. (2008). "Les carnyx du dépôt cultuel du sanctuaire gaulois de Tintignac à Naves (Corrèze)." In: Studien zur Musikarchäologie VI: Herausforderung und Ziele der Musikarchäologie, ed. A. A. Both, R. Eichmann, E. Hickmann \& L. C. Koch. Orient-Archäologie 22. Rahden, Westf.: Verlag Marie Leidorf: 57-76.

Pearson, G. (1796). "Observations on some ancient metallic Arms and Utensils; with Experiments to determine their Composition." Philosophical transactions of the Royal Society of London for the year MDCCXCVI, part 1: 395-451. London: Royal Society.

Phené, J. S. (1877). "On the KARNYX, or Keltic Horn." JBAA XXXIII: 395-400.

Poste, the Rev. Beale. (1858). "Remarks on some Representations of Minstrels in early Painted Glass." JBAA XIV: 129131 \& Figs. 1-3.

Roach Smith, C. See Smith. 
Smith, C. R. (1857). Collectanea Antiqua: etchings and notices of ancient remains, illustrative of the habits, customs, and history of the past ages. Volume IV. London: J. R. Smith (Series 1848-80).

Spencer, H. (1857). "The origin and Function of Music." Fraser's Magazine, October 1857.

Stukeley, W. (1724). Itinerarium Curiosum: or, an account of the antiquitys and remarkable curiositys in nature and art, observ'd in travels thro' Great Britain. London: privately printed. (2nd ed. Itinerarium Curiosum: or, an account of the antiquities, and remarkable curiosities in nature or art, observed in travels through Great Britain. London: Baker \& Leigh, 1776).

Veeck, W. (1931). Die Alamannen in Württemberg. Berlin.

Way, A. (1861). "Commentary on items exhibited, in the Proceedings at Meetings of the Institute." Arch. J 18: 150.

Zon, B. (2007). Representing Non-Western Music in Nineteenth-century Britain. Rochester and Woodbridge: University of Rochester Press and Boydell \& Brewer Limited (Eastman Studies in Music). 

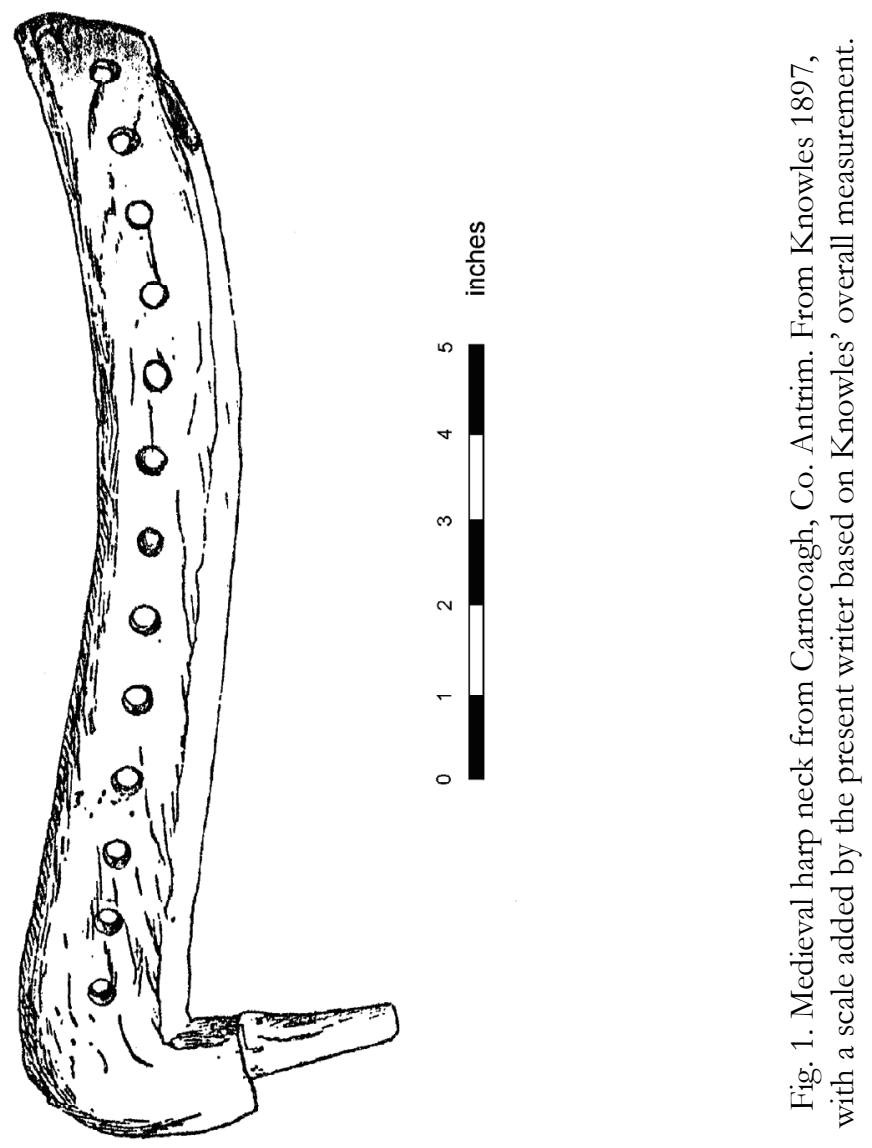


$$
\nabla
$$




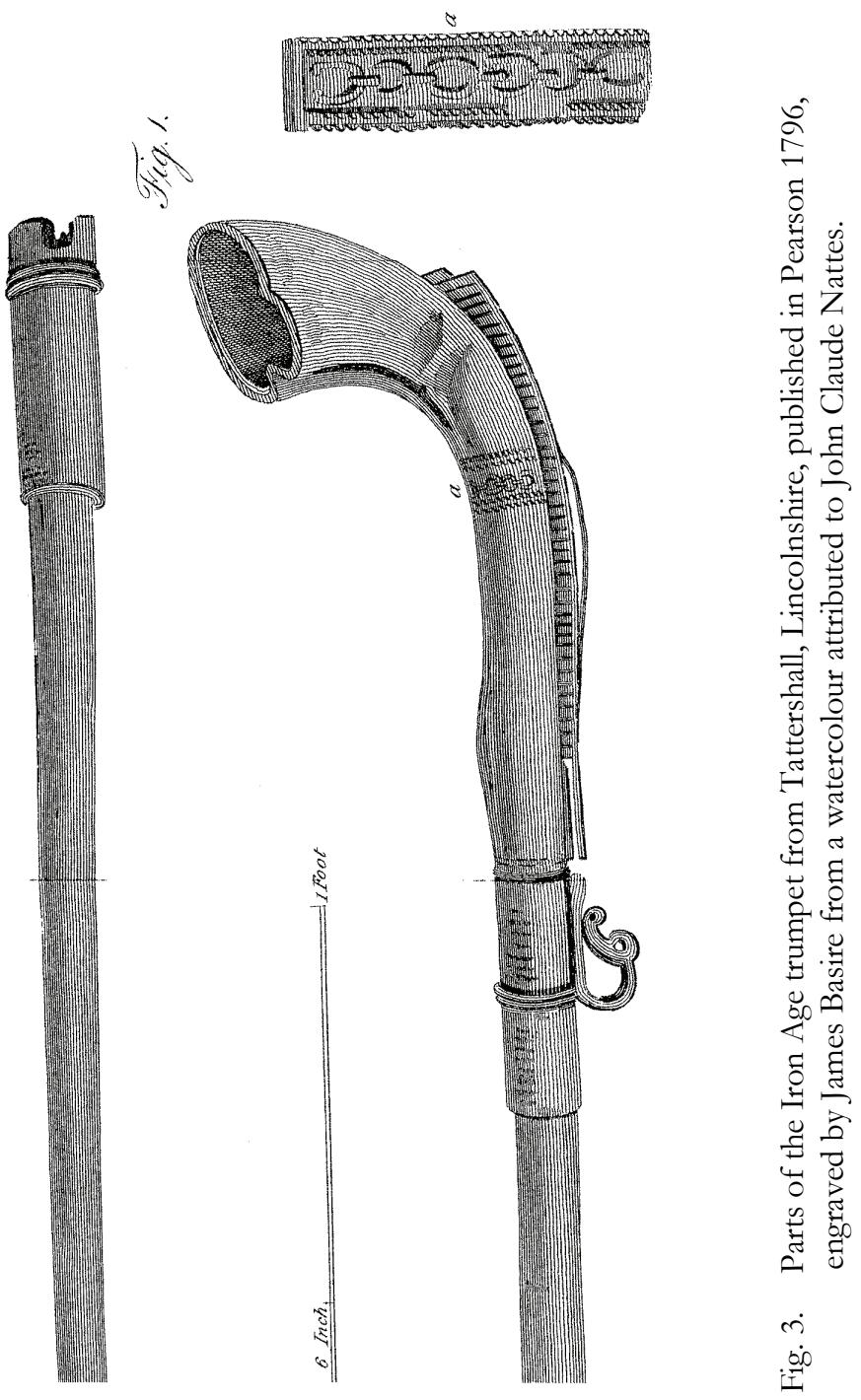




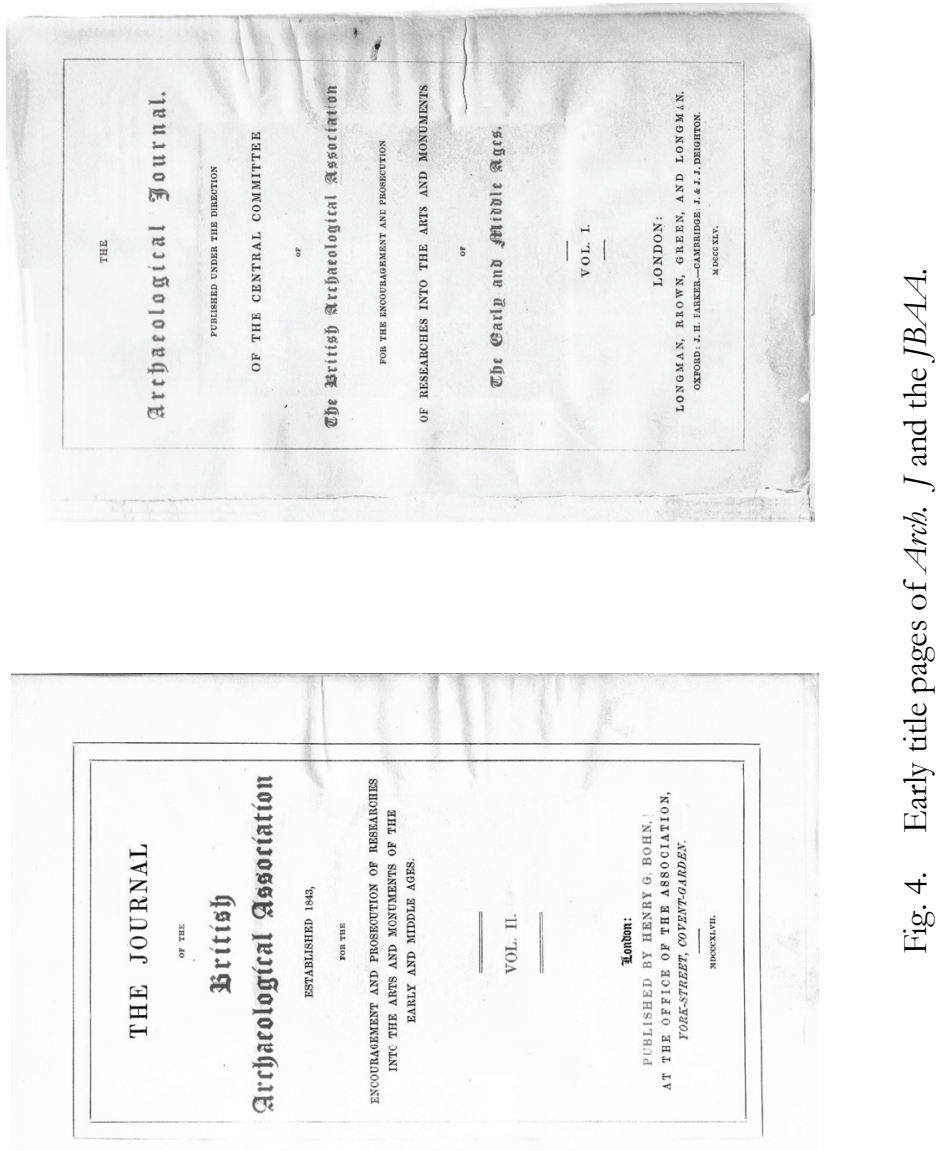


OF THA MIDDLE AGES.

also nsed to designate a wind instrument, of which wo shall speak further on.

THE HARP.

The discovery of the harp among the sculptures of the monuments of ancient Egypt is a sufficient proof of its antiquity; yet it appears not to have been in use among the Greeks-at least it is not found among tho numerous monuments of that people. It is in the middle ages, with the invasions of the northern peoples, that the harp first makes its appearance in Western Europe. Fortunatus speaks of it as belonging especially to the Germanic tribesRomanasque lyra, plaudat tibi barbarus harpa. (Eib. rif.)

And again-

Sola sope bombieans barbaros leudos harpa relidebat.

(Epist. lib. i.)

The most ancient figure of this instrument at present known, is that taken by the abbe Gerbert from the MS. of St. Blaise of the ninth century, and reproduced in our cut, figure 4. This instrument, mounted with twelve strings and pierced with two soundingholes, is remarkable for the simplicity and elegance of its form. The words cythara Anglica, written above the figure in the manuscript, indicater probably that it was in use among the Anglo-Saxons from whom perhaps it was adopted by the Celtic tribes. Ed.)

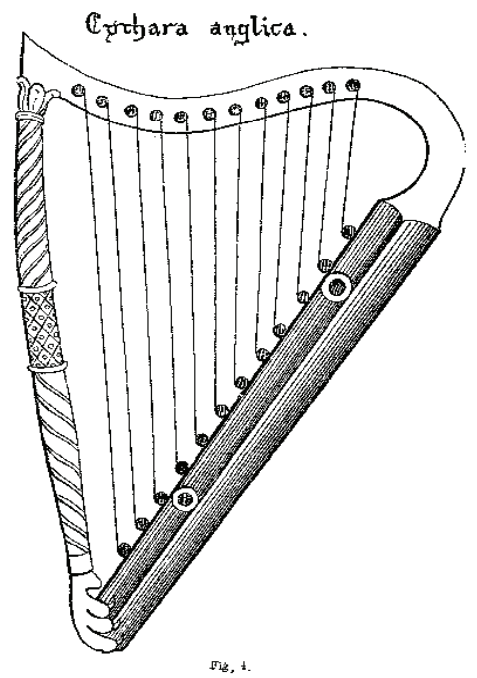

Fig. 5. Harp, labelled "Cythara anglica," from a medieval manuscript (de Coussemaker 1847, from Gerbert). 
and of which we shall speak in its place. It dates from the end of the eighth century or the beginning of the ninth; but an instrument of the same kind is mentioned in the following line of a poem of Fortunatus, written two centuries earlier :-

Grweus achilliara chrotta Britanna canat.

The crout, of the antiquity of which there can be no question, remained long the favourite instrument of the Welsh or Cambro-British bards. We give from the thitd volume of the Archcelogia, the figure of a erout of six strings, taken from a manuscript of the eleventh century (fig. 6). It is an instrument composed of an oblong sonorous box, having the keyboard in the middle. It has six strings, of which four are placed above the keyboard, and two beyond it.

This instrument, which is still in use in some parts of the British Isles, has preserved nearly its primitive form and has undergone few modifications. With the exception of a cordies, or neck, and some strings added, it remains the same as it was in the eleventh century, as may bo judged by a figure rather rudely drawn, which we give (fig. 7 , see next page) from a manuscript of the eleventh century. The crout had then but three cords;

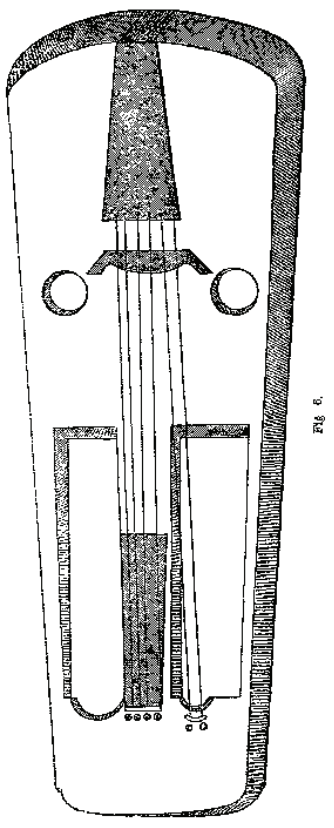
it was placed, as we see, on the knees of the performer. As the personage here playing upon it is, among all those represented in the manuscript, the only one with a crown on his head, we are justified in supposing that the artist looked upon the crout as a more noble instrument than the psalterion and others there representer.

Fig. 6. "Crout" from a medieval manuscript (de Coussemaker 1847, from Archaeologia III). 


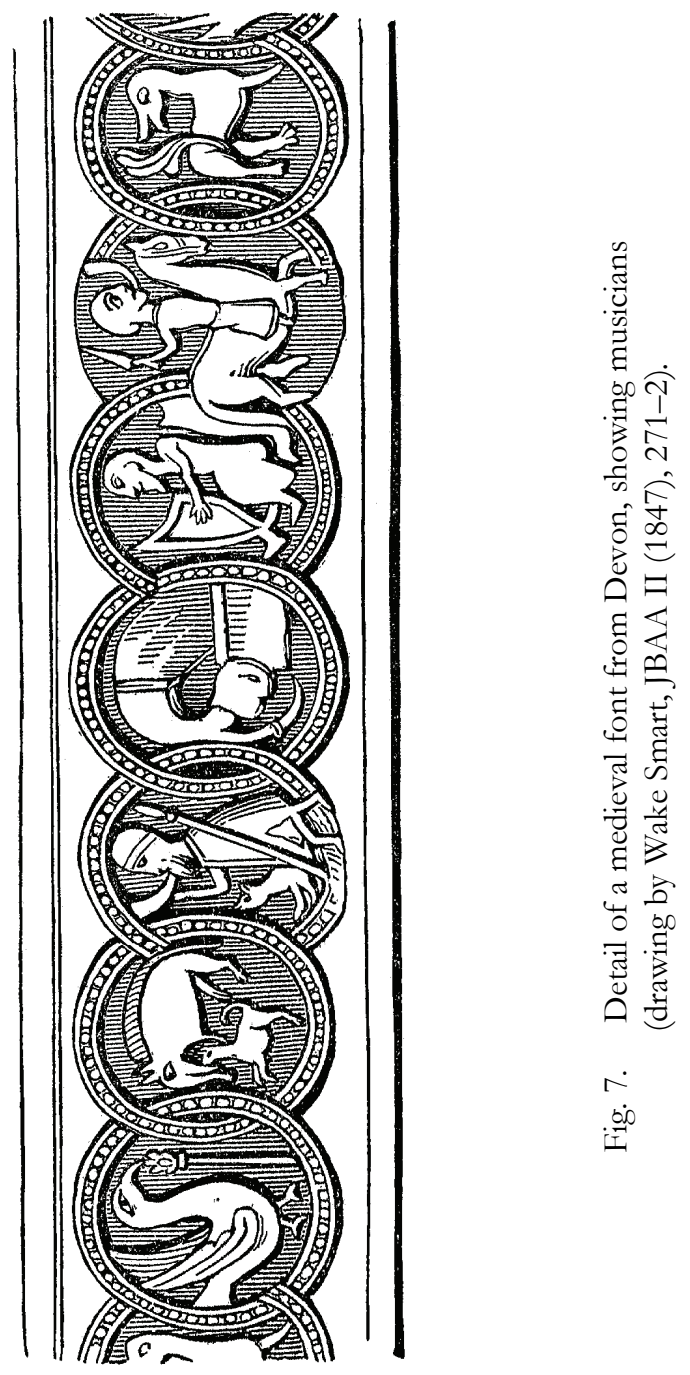


of the ear, whence the poctical compound dudaireachd, the noise of horns and trumpets. O'Brien, in his Dictionary, transkates the word dudng, a trumpet, or hornpipe; and Walker (page 88) says, - "Perhaps the dudag was a spccies of clarion, or octave trumpet, called by the Latins, liturs." In Mr. Crofton Croker's valuable collection is a straight tube of brass, which was discovered at the same tirne and place as his stoc, which, I corjecture, is the stem of a dudag; and examples of the more complcte instrument are given in Smith"s Fistory of Cor\%. The head of the trumpet resembled the stoc in form, and the tube was inserted into the small end, thus producing an instrument whose form must be familiar to many under the name of the "stock-and-horn", and which was probably the archetype of this brazen dudag." The gall. trompa, - i.e., tho foreigners' tmumpet,_is another instrument mentioned in the Irish annals. Nothing is known of its form, but it was probably derived from the Danes or some other invaders.

Gold seems to have been employed as a material for trumpets in the north of Europe at a very remote period. The hunting horn of Gunter, the Burgundian monarch, who plays so conspicuous a part in the Nibelungen $\mathrm{Lay}^{2}$ is described as of this metal:

"A boun of the gold so red o'er the champion's shoulderts limg."

And in the king of Denmark's collection are examples of horns formed of gold. One specimen was found on the 20 th of July 1639 , on the road to Ripen, in North Jutland." This horn weighs ninety-nine ounces two drams,

\footnotetext{
1 Mr. Croftor Cyolzer also possesses a "White-hoy"s born", in use sumiong the Irish rebels of 1798. It is in the shape There are three old manuscript copies of the horns of tho mail-coach guards nich but rerr mith bros, and jointed, of the lay, in a collection of so that it may be slid up Ijko a tele- works, in the latter part of the last seope, for the purpose of bejing carried century; and an English translation in the pocket.

2 The song of the Nibelangen is the most ancient of all the Teutonic ine trical xonanees which have deseended

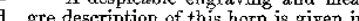
to us entire. As it now exists, it ap- the "Gentieman's Margazine", $x z 11,2 \delta$. pears to have been sritten in the For a full acomut, the ruader must twelfth century, but it is evidently a refert to Wormius' "Mon. Dar."
}

Fig. 8. Henry Cuming, on prehistoric Irish and other horns (Cuming 1850). 
graving), is of an elegant and unusual shape: it is of brass,

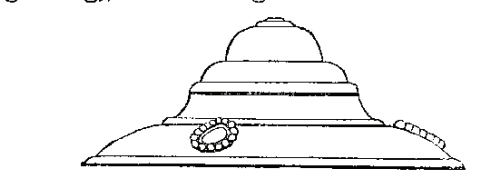
with iron fixings, and is ornamented with three beaded studs. ${ }^{1}$ With it were found a few bits of thin brass.

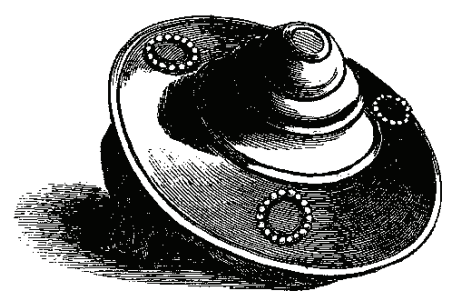

The smallglobular bronze bell, which is engraved of the full size of the original (see fig. 1), was found during the excavations, at the same depth as the other Roman remains. It is of the same shape as those used for horse bells at the present day. Bells of similar shape have been found with Roman remains at Heydon and Chesterford, by the hon. R. C. Neville, and at other places; and I am informed by my friend Mr. Joseph Clarke, that there is one now preserved in the museum of the Cambridge Antiquarian Society, labelled as a" "bead, found at Shefford with seven Roman urns". In the collection of Mr. E. B. Price, are two bells of nearly similar size, and
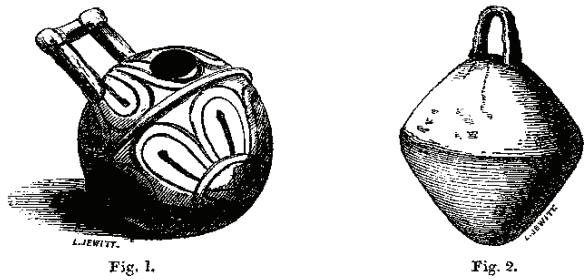

two others, three inches and a half in diameter, of apparently much later manufacture; there are also specimens in the Colchester Museum. ${ }^{2}$

$1 \mathrm{Mr}$. C. Noach Smith has suggested, that this might have been the boss of a coffer, or small wooden chest.

2 As the subject of bells is one of great interest, it is hoped that particulars of their discovery may be for-

Fig. 9. Globular brass bell from Oxfordshire (Ll. Jewitt 1851). 
Plate X7.

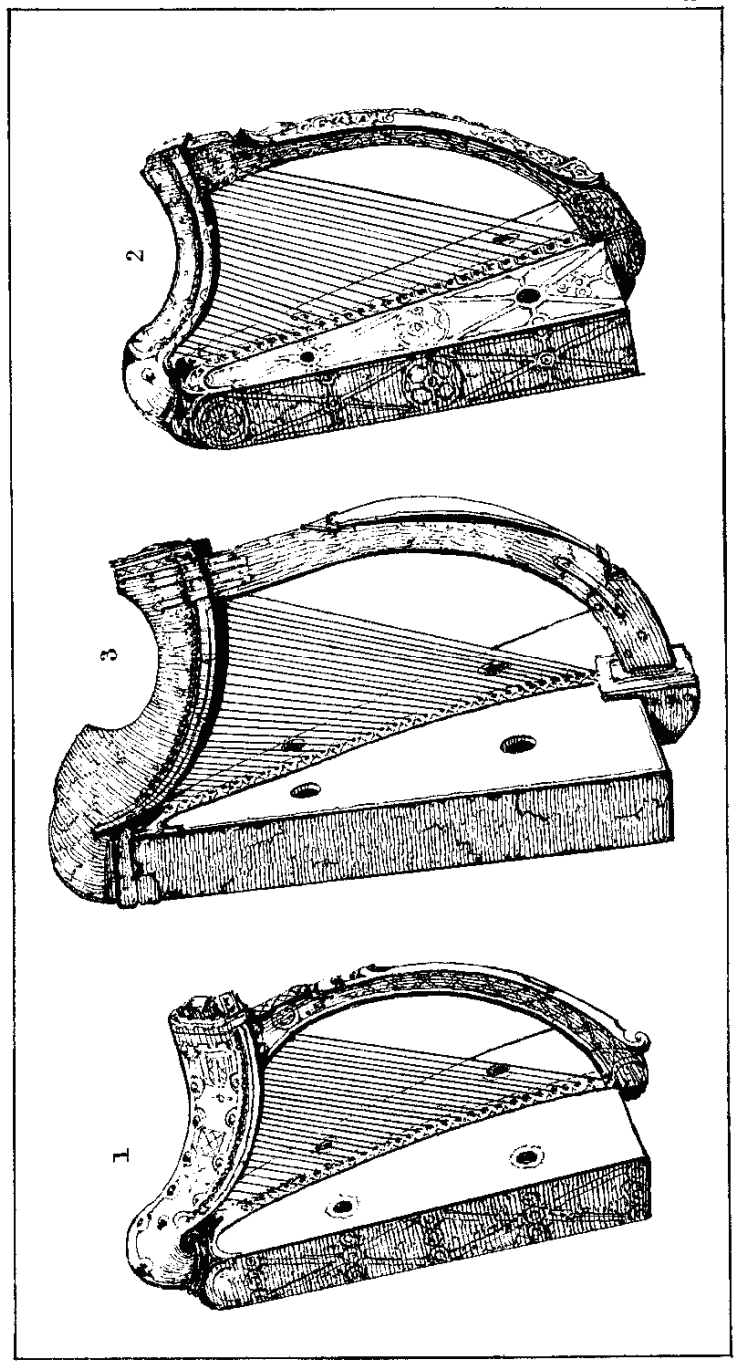

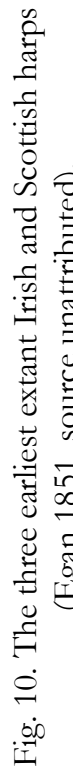




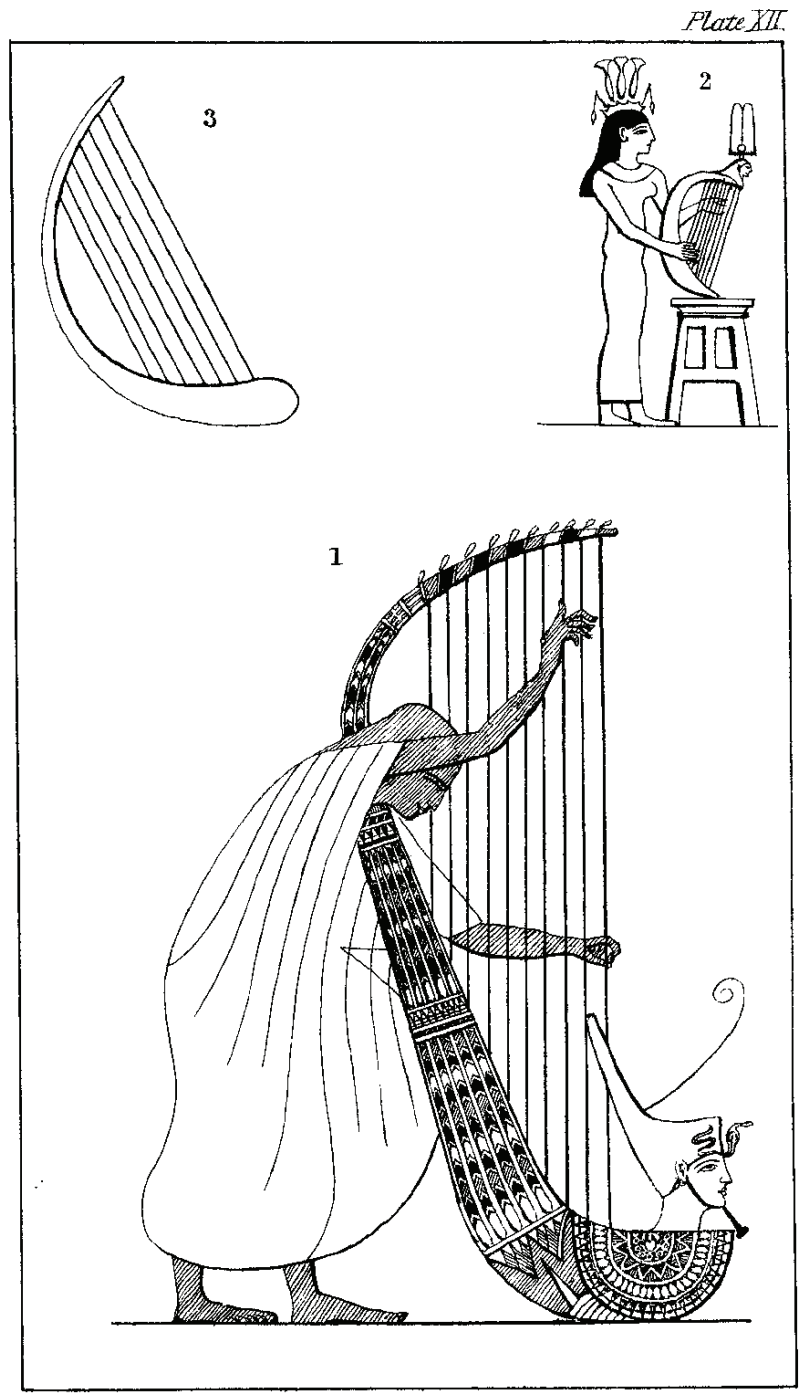

Fig. 11. Egyptian harps (Egan 1851, the lower figure after J. Gardner Wilkinson, unattributed). 


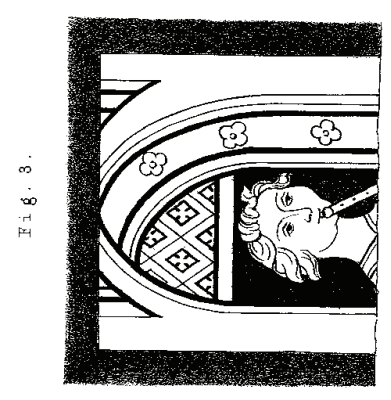

善
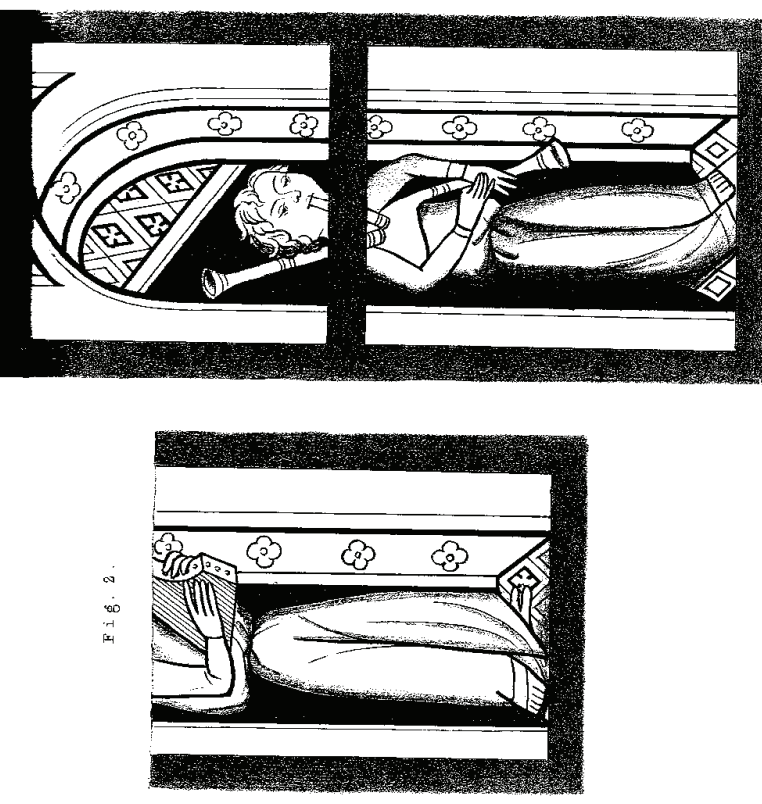

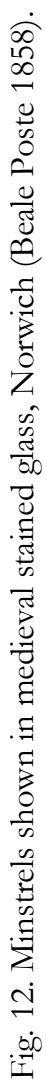




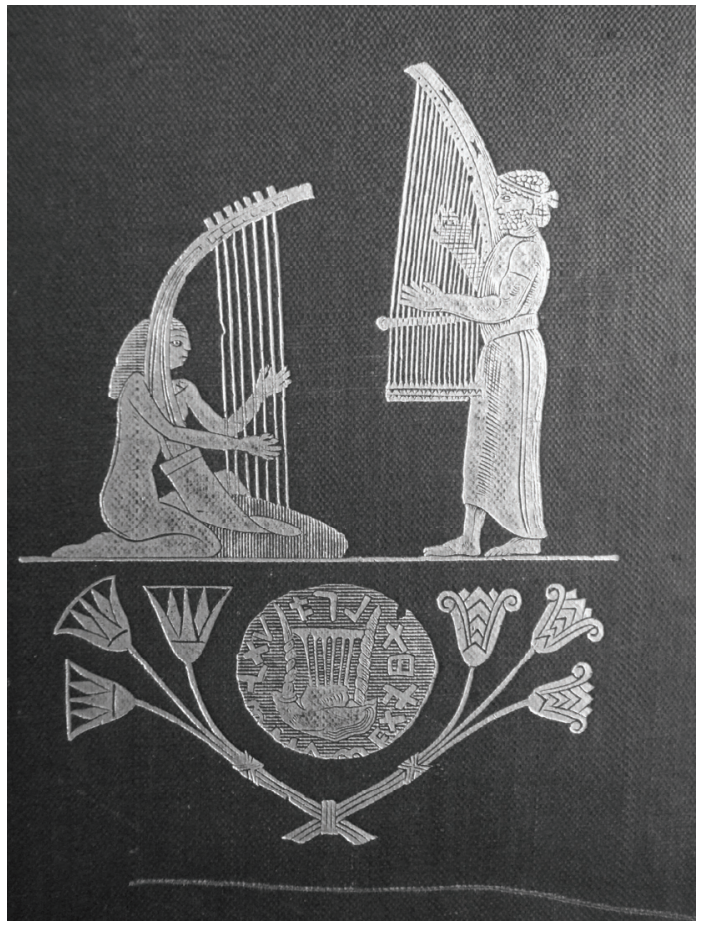

Fig. 13. Detail of the cover of Carl Engel's The Music of the Most Ancient Nations (second edition, 1870). 


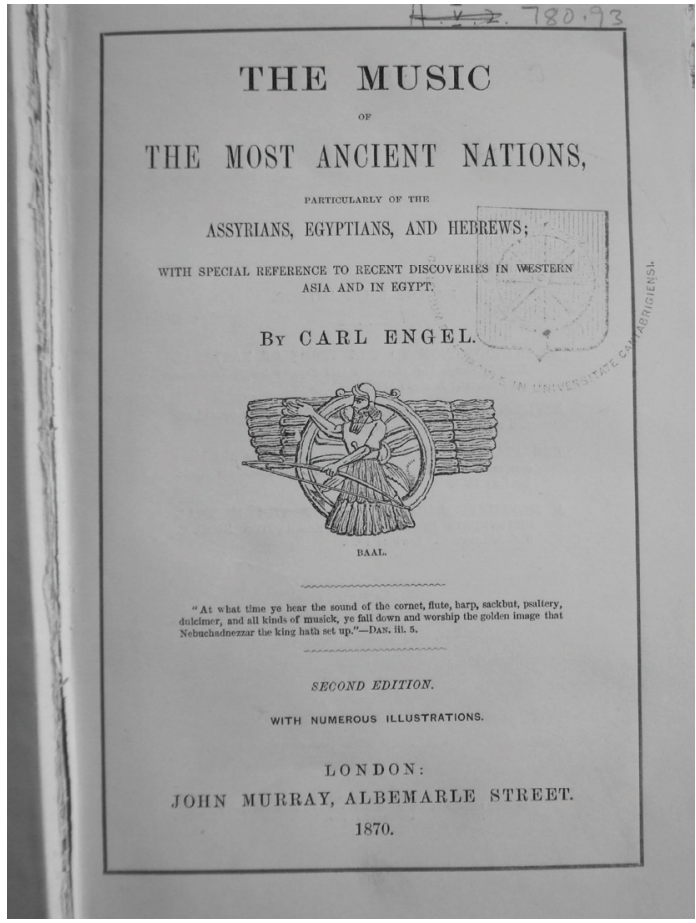

Fig. 14. Title page

of Carl Engel's The Music of the Most Ancient Nations (second edition, 1870). 


\title{
THE FALSE DECIPHERMENT OF CUNEIFORM 'NOTATION' IN THE EARLY TWENTIETH CENTURY
}

\author{
SAM MIRELMAN
}

\begin{abstract}
From 1915 until the mid 1950s several scholars, notably Curt Sachs and Francis W. Galpin, have suggested that a series of cuneiform signs in a literary text dating to the first millennium $B C E$ are a form of musical notation. From today's standpoint, it is absolutely clear that the text concerned does not contain musical notation. However, these interpretations provide us with an intriguing historiographical case study. Due to the absence of any true musical information in their source materials, this small event in the history of musical scholarship offers us a rare glimpse into the perception of "ancient music" in the early twentieth century.
\end{abstract}

In 1915, the Assyriologist Bruno Meissner was the first to suggest that the (then) mysterious syllables at the beginning of each line in an Assyrian literary text (dating to ca. $800 \mathrm{BCE}$ ) might be musical notation (Meissner 1915, 333). Another Assyriologist, Erich Ebeling, agreed with Meissner (Ebeling 1916, 532). The musicologist Curt Sachs developed this idea into a full blown analysis (Sachs 1924a, 40-41; Sachs 1924b; Sachs 1925). Yet another Assyriologist, Albert Schott, considered Sachs' thesis to be an ingenious decipherment which confirmed that this text was certainly musical notation (Schott 1928, 368). The historian of science Otto Neugebauer also affirmed Sachs' interpretation, making an analogy between Mesopotamian knowledge of music, 
and mathematical and harmonic proportion (Neugebauer 1931-32, 96). Then the Assyriologist Benno Landsberger convincingly rejected Sachs' thesis, by demonstrating that the text is in fact an exemplar of "Silbenalphabet A," a lexical text which was an exercise for apprentice scribes who were learning to write cuneiform in antiquity (Landsberger 1933). The musicologist Francis W. Galpin rejected Landsberger's reasoning without a full understanding of the philological argument. Galpin's musical decipherment was different from Sachs (Galpin 1937, 42-50), although both of their detailed theories were based on the false premiss that this text involves musical notation. Later, Sachs published a response to both Landsberger and Galpin, re-asserting his conviction that this text is almost certainly musical notation (Sachs 1941).

A misunderstanding of the text persisted for at least another decade. Taha Baqir supported Sachs and Galpin, seemingly without considering Landsberger's article (Baqir 1946, 29-30). Baqir's argument is supported with reference to the very different "notations" in late copies of Sumerian lamentations. These are without doubt performative indications, although they bear no relation to what is under consideration here. ${ }^{1}$ The musicologist Claire C. J. Polin also held the view that the Assyrian text employs musical notation, although evidently without full knowledge of Landsberger's argument (Polin 1954, 14). Thus, it was Meissner's original misconception that persisted for at least four decades, and which led to Sachs' and Galpin's more convoluted misunderstandings.

From today's standpoint, it is absolutely clear that the text concerned does not contain musical notation; it is indeed a lexical text. This is proven conclusively by our improved knowledge of such lexical texts known from many duplicate manuscripts. ${ }^{2}$ The

${ }^{1}$ For a study of such performative indications, see Mirelman 2010.

${ }^{2}$ For a summary of previous studies on these types of lexical texts, see Cavigneaux 1980-81, 618-20. The text under discussion here is completely unrelated to the one known example of musical notation from the second millennium BCE, known from the 1960s onwards (see Kilmer 1995-1997; Kilmer 2001). 
presence of the lexical text "Silbenalphabet A" on the same tablet as a creation myth (the main reason for its misinterpretation) can be explained only as a corruption in the text's transmission (as suggested by Cavigneaux, 1980-81, 618-20). However, such a case of spectacular misinterpretation provides us with an intriguing historiographical case study. Sachs' and Galpin's interpretations involved "transcriptions" of the text's supposed musical content into standard western notation, with fully justified "reasoning" based on comparisons with other non-European musics. Without any intent to ridicule two important and distinguished musicologists of the early twentieth century, Sachs' and Galpin's detailed methods of interpretation merit consideration. Due to the absence of any true musical information in their source materials, this small event in the history of music offers us a rare glimpse into the perception of "ancient music" in the early twentieth century.

The text itself is written in the cuneiform writing system, on a clay tablet. Such tablets are conventionally represented by a drawing (Fig. 1). The literary text, which is a creation myth, takes up the majority of the tablet's surface. The column on the left (boxed in on Fig. 1) shows where the alleged musical notation is physically situated. Cuneiform writing is normally read from top to bottom, left to right. It is not normally alphabetic, but rather a combination of syllabic and logographic systems. The relevant column indicates simple syllables in repetitive sequences:

me me kur kur

a a a a a

ku ku lu lu

maš maš maš

etc...

Sachs' initial interpretation (1924a; 1924b; 1925) took the syllables as a notation for the harp, which Sachs assumed would accompany the performance of the creation myth. Sachs interpreted open syllables like me as single notes and closed syllables like kur as ligatures of two notes. According to Sachs, out of the tones C D E F F\# G A B C, the Babylonians used four partly overlapping pentatonic scales. The initial consonant or vowel of each syllable (or half-syllable) was allocated to a single note. Sachs assumed that a tetrachordal system is apparent, because it is known in ancient Greek and Hebrew music, although precisely 
what Sachs meant here by "Hebrew" is unclear. Sachs believed that in "primitive and oriental music," scales generally descend; this attitude must come from knowledge of ancient Greek music, where scales do generally descend.

According to the "principle of comparative musicology," the popularity of vowels and consonants were analyzed by Sachs, and predominant pairs are presumed to be pairs (played together) in a fifth/fourth relationship. The next level of popularity in terms of pairs of presumed notes were taken as the following notes in the cycle of fifths, and so on. The whole system was assumed to be Chinese in character, and further evidence of the conspicuous relationship between the Near East and China (Sachs 1925, 22). The importance of this text for the history of music was stressed for its being the only instance from Antiquity of what might be called harmony, or "mehrgriffiger Instrumentalmusik" (Sachs 1924a, 41).

Galpin (Galpin 1937, 42-50) made yet a more elaborate argument, comparing this supposed notation to music in ancient China, in order to justify the choice of scale. However, Galpin's mapping of the Hebrew alphabet onto a supposed twenty one note scale, is based on a conglomeration of what was known about the use of the alphabet in ancient Greek notation, as well as a supposed "Semitic" communal scale. Needless to say, there are various holes in Galpin's argument. Hebrew and the cuneiform language Akkadian both belong to the Semitic family of languages, but of course this does not mean that the speakers of these languages shared the same scale. Galpin takes this lumping together of all Antiquity to an extreme. Thus, Galpin provided a full transcription of the melody (Fig. 2), in octaves because in some writings of Plato and Aristotle, and according to the "usual custom of Oriental peoples" the accompaniment is usually in octaves, or unison with the voice, as well as ornamental grace notes, as known in "ancient Indian chanting."

In 1941 Sachs published a rebuttal of Galpin's interpretation, in response to what Sachs perceived as the danger of musicians performing "the world's oldest music" in all schools coast to coast (Sachs 1941). Although Sachs expressed a measure of doubt that this text was musical notation, in response to Landsberger, Sachs still said it was possibly notation, but that his own earlier interpretation requires revision. This time, Sachs preferred to 
interpret syllables as groups of notes instead of single notes. Sachs' reasoning was based on the fact that such notations are known in both Ethiopia and south India. Such "stereotyped groups of notes" belong to the "particular ornamental style which we roughly call 'oriental', and that persisted to the period of the German Meistersinger" (Sachs 1941, 68).

Despite their differences, and the comparatively higher level of sophistication in the case of Sachs, both Sachs' and Galpin's views of what music must have been like in ancient Mesopotamia are typical of their time. The West/ "rest" dichotomy was often taken to an extreme in this period. ${ }^{3}$ Thus, Sachs' and Galpin's treatment of all ancient non-western music as essentially similar, is not extraordinary in this context. Nineteenth century European historiography often required the conscious situation of the "other" in relation to Europe. This situating of the "other" as a unified, universal concept, may underlie Sachs' and Galpin's view of ancient music as something which is fundamentally similar in ancient Sumer, China, Greece and indeed the whole world. As Philip Bohlman states, in an essay on the European discovery of music in the Islamic world and the non-western in nineteenth century music history, the earliest stage of "universal history" in this period was the oriental world (Bohlman 1987).

Another important theme of this period was the theory of evolution and diffusion known as Kulturkreislehre ("culture circles"). In this conception of musical cultures, Hochkultur ("high culture"), and allied notions of Kulturvölker ("culture people") and Naturvölker ("nature people"), played a central role. As can be expected, a principal characteristic of Hochkultur was perceived to be the use of writing, which was (and is) thought to have originated in Sumer, closely followed by China. In Erich von Hornbostel's 'Die Massnorm als Kulturgeschichtliches Forschungsmittel,' a special relationship between Sumer and China was assumed, where what are perceived to be similar systems of general measurement are thought to embody a similar concept of musical measurement. As two principal centres of Hochkultur, Sumer and China were treated as the most important examples in ancient history.

\footnotetext{
${ }^{3}$ See Irving in this volume.
} 
Hornbostel specifically stated that the Massnorm ("norm of measurement") was only characteristic of Hochkultur, and that Hochkultur has a single origin from which it may spread. The single origin of Hochkultur was presumed to be situated somewhere geographically "in the middle" between Sumer and China-i.e. the Caucasus (Hornbostel 1928, 322-23; cf. Schneider 1976, 126). This theory was also followed in a similar essay by Siegfried Nadel, on pipes in the Caucasus (Nadel 1934). Hornbostel's perceived close relationship between ancient China and Sumer/Babylon was characteristic of the period (Schneider 1976, 135-45). In an even more outlandish essay Hornbostel suggested that ancient Peruvian exact measures originated in Mesopotamia, and furthermore, that this relationship of exact measures must indicate that their musical instruments were also built to the same proportion, and thus the music of both extremely distant cultures must be related (Hornbostel 1931). These essays appeared in the 1920s and 1930s, but similar interpretations and supposed decipherments of notation were not unknown. In 1913 the colourful figure Oskar Fleischer wrote an essay 'Eine astronomisch-musikalische Zeichen-schrift in neolithischer Zeit,' which interpreted the signs on the European "Trichter" type of drum as musical notation, partly due to its similarity to signs for planets, which Fleischer connected with the ancient Greek notion of the music of the spheres, as well as Mesopotamian symbols for planets (Fleischer 1913). Such an ideologically motivated interest in the earliest evidence for music, is closely related to an older preoccupation with the origins of music in the nineteenth century onwards, which in itself must be seen in the context of the emergence of musicology as an independent discipline (Rehding 2000).

Sachs' and Galpin's “decipherments” of an Assyrian literary text were based on methodologies which embodied principles of comparative musicology. It has often been stated that comparative musicology in this period treated non-western living music as history; the use of comparisons with such musics to decipher ancient music, is thus a way of reinforcing such a view. Furthermore, the treatment of all non-western ancient music as a unified whole, reinforces a view of evolution and diffusion where a single origin is presumed. The "discovery" of this text caused such excitement not only because of its antiquity. Instead, it was the 
prospect of the text reinforcing an intellectual belief system which led to the text's perceived importance over several decades.

\section{BIBLIOGRAPHY}

Baqir, T. (1946). "Tell Harmal: A Preliminary Report.” Sumer 2: 2230.

Bohlman, P. V. (1987). "The European Discovery of Music in the Islamic World and the 'Non-Western' in 19th Century Music History." The Journal of Musicology 5.2: 147-63.

Cavigneaux, A. (1980-81). "Lexikalische Listen." Reallexikon der Assyriologie und vorderasiatischen Archäologie 6: 609-41.

Ebeling, E. (1916). "Die Erschaffung des Menschen bei den Babyloniern." Zeitschrift der Deutschen Morgenländischen Gesellschaft 70: 532-38.

- (1919-1923). Keilschrifttexte aus Assur: religiösen Inhalts, 2 vols. Leipzig: Hinrichs.

Fleischer, O. (1913) "Eine astronomisch-musikalische Zeichenschrift in neolithischer Zeit." Memnon 7: 1-19.

Galpin, F. W. (1937). The Music of the Sumerians and their immediate successors, the Babylonians and Assyrians. Cambridge University Press.

Hornbostel, E. M. von. (1928). "Die Massnorm als kulturgeschichtliches Forschungsmittel." In: Festschrift P. W. Schmidt, ed. W. Koppers. Vienna: Mechitharisten Congregations Buchdrückerei: 303-23.

(1931) "Die Herkunft der altperuanischen Gewichtsnorm." Anthropos 26: 255-58.

Kilmer, A. D. (1995-1997). "Musik. A. I. In Mesopotamien." In: Reallexikon der Assyriologie und vorderasiatischen Archäologie 8: 463-82.

(2001) "Mesopotamia." In: The New Grove Dictionary of Music and Musicians II.16: 480-87.

Landsberger, B. (1933). 'Die angebliche babylonische Notenschrift.' In: Aus fünf Jahrtauseden morgenländischer Kultur: Festschrift Max Freiherrn von Oppenheim zum 70: Geburtstage gewidmet, von Freunden und Mitarbeitern, ed. E. F. Weidner. Archiv für Orientforschung Beiband I: 170-78.

Meissner, B. (1915). Review of Keilschrifttexte aus Assur religiösen Inhalts, vol. 1, Leipzig: Hinrichs, by E. Ebeling. Orientalische Literaturzeitung 18: 331-37. 
Mirelman, S. (2010). "Performative Indications in Late Babylonian Texts." In: Musicians and the Tradition of Literature in the Ancient Near East, ed. R. Pruzsinszky and D. Shehata. Vienna: Wiener Offene Orientalistik: 241-64.

Nadel, S. F. (1934). "Messungen an kaukasischen Grifflochpfeifen." Anthropos 29: 469-75.

Neugebauer, O. (1931-1932). "Über die Approximation irrationaler Quadratwurzeln." Archiv für Orientforschung 7: 90-99.

Polin, C. C. J. (1954). Music of the Ancient Near East. Westport, Connecticut: Greenwood Press.

Rehding, A. (2000). "The Quest for the Origins of Music in Germany circa 1900." Journal of the American Musicological Society 53.2: 345-85.

Sachs, C. (1924a). Musik des Altertums. Breslau: Ferdinand Hirt. (1924b). "Die Entzifferung einer Babylonischen Notenschrift: Vorbericht." Vorgelegt von Hr. Stumpf. Sitzungsberichte der Preussischen Akademie der Wissenschaften 18: $120-23$.

(1925). "Ein babylonischer Hymnus." Archiv für Musikwissenschaft 7.1: 1-22. (1941). "The Mystery of the Babylonian Notation." The Musical Quarterly 27.1: 62-9.

Schneider, A. (1976). Musikwissenschaft und Kulturkreislehre: Zur Methodik und Geschichte der Vergleichenden Musikwissenschaft. Bonn: Verlag für systematische Musikwissenschaft.

Schott, A. (1928). Review of Die Babylonische-Assyrische Literatur. Vol. 1, Akademische Verlagsgesellschaft Athenaion. Wildpark-Potsdam (1927), by B. Meissner. Orientalische Literaturzeitung 31: 367-9. 


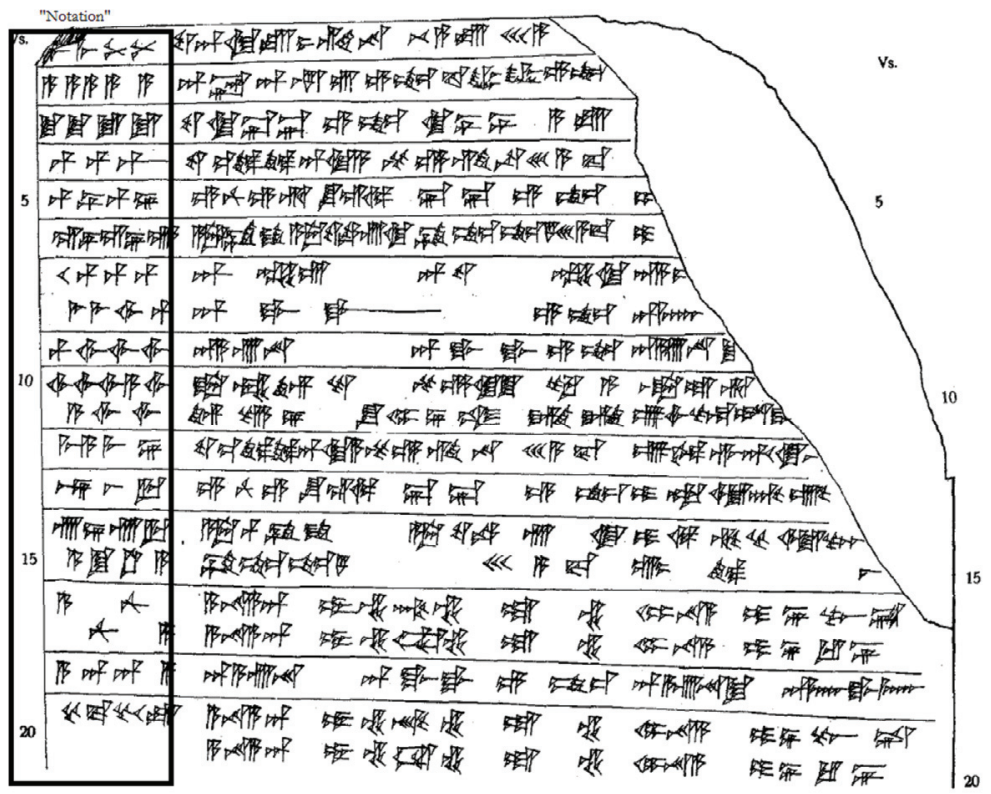

Fig. 1. A drawing of the Assyrian literary text with the alleged column of musical notation (Ebeling 1919-1923, 6). 


\section{A SUMERIAN HYMN ON THE GREATION OF MAN}

With harp accompaniment of the second millennium в.c.

(The singer, no doubt, ornamented his part with grace-notes as in the ancient Indian chanting, and the intervals, taken in ascent by a skip, were rendered in descent with a light slide. The crotchet notation has no definite time-value; it merely denotes melodic progressions. Rhythm and stress depend on the words. The small numbers mark the hymn lines. For Sumerian pronunciation see p. xi.)
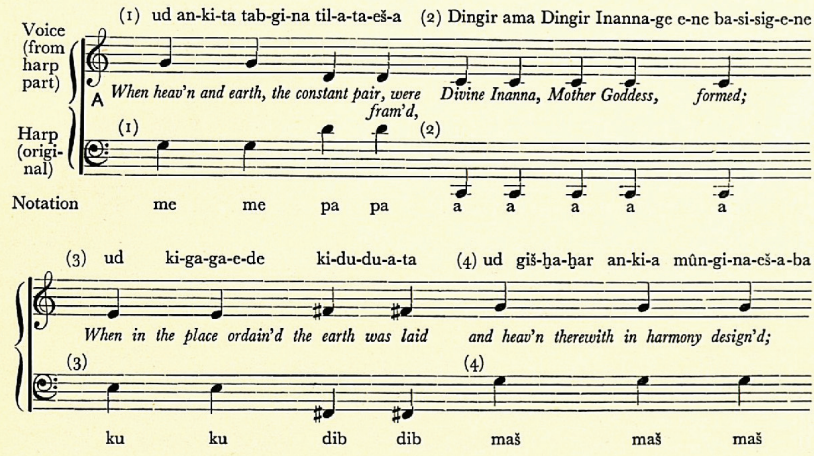

ku

$\mathrm{ku}$

maš

maš

(5) e pa-ri šu-si-sa ga-ga-e-de (6) id idigna id buranun gu-ne-ne gar-eš-a-ba

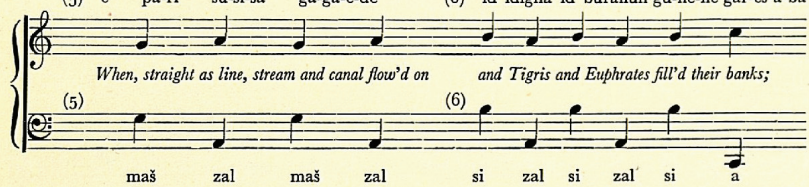

maš

zal maš zal

si zal si zal $^{+}$si

(7) An Dingir En-lil Dingir Utu Dingir En-ki (8) Dingir ga-gal-e-ne

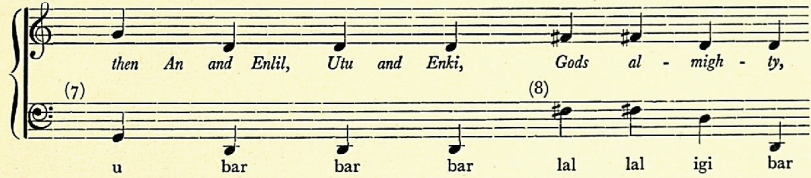

(9) (10) ( 11 )

(I I)

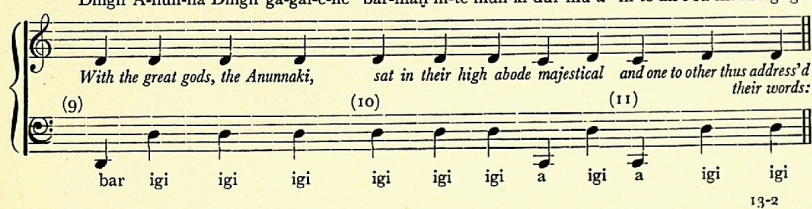

Fig. 2. Galpin's reconstruction

of the supposed cuneiform notation

(Galpin 1937, 99). 


\title{
STUdIES OF ANCIENT NORDIC MUSIC, 1915-1940
}

\author{
GJERMUND KOLLTVEIT
}

The pioneers who contributed towards the formative period of Scandinavian musicology (ca. 1915-1940) were bighly interested in ancient music. This essay describes these individuals' approaches and methods, seeking to place their work in the context of the cultural, political, and academic ideas of the period. Some of the scholars were notably influenced by nationalism, whereas others were more concerned with a common Nordic musical beritage. Moreover, Nordic identities were often parallel to national identities. The interest in ancient music in this period was sometimes related to evolutionary theories. More often, however, the scholars tended to view the history of music as a decline, from an ancient golden age to the present, where only remnants from ancient times survive. The pioneers discussed in this essay include Angul Hammerich, Hortense Panum, Otto Andersson, Tobias Norlind, Christian Leden and Geirr Tveitt.

In Nordic countries musicology was a young discipline in the interwar period, still to be established and fully institutionalized. The leading figures of the time featured diverse approaches to their research, often including ethnographic methods. These pioneers usually had a special interest in ancient music. Within musicology as well as the other humanities, the interest in ancient culture during the pioneer phase should be understood against a backdrop of nationalism. This was especially important in Nordic countries, situated on the periphery of Europe, and having to articulate their 
place in relation to more prominent nations. Some scholars were also concerned with the idea of a common Nordic ancient heritage, in addition to nationally-focussed research projects. Others sought to integrate their Nordic musical heritage within the mainstream European tradition.

This article is a survey of ancient Nordic music in the period ca. 1915-1940, encompassing the concept in its varied cultural, political and intellectual contexts. How was ancient music described? Which topics were of special interest to the authors? Which historiographical methods were prevalent? Was music of the distant past a goal in itself, or was it merely used as a means to promote ideas of the present? My aim is to show the diversity within this area of research, which was not governed by one single paradigm. Although most of the authors discussed here might be called musicologists or music historians, they represented various positions and methodologies. I have selected the researchers and musicological works that were most influential in the area of ancient music, yet the selections make no claim to being complete or fully representative for the entire Nordic region. The Nordic region is defined here as Scandinavia, i. e. Denmark, Sweden and Norway, with Finland, Iceland, Greenland and the Faeroe Islands. This is in keeping with modern terminology within these countries. In the English language, Scandinavia is often used as a common name for the entire Nordic region. This is not a misunderstanding, but a result of the close relationship between the two terms. Scandinavia is the basis for a common Nordic history, culture, and notably language. Finland is part of the political community of Nordic countries, but the Finnish-speaking part of the country has less cultural and historical bonds with the western Nordic countries. ${ }^{1}$ "Norse" usually means the Scandinavian language groups, but is also used as a name for the Scandinavian culture of the Early Middle Ages or earlier. When scholars and authors use

${ }^{1}$ Within the Nordic region, there are other people apart from those descended from Norse- or Scandinavian-speaking populations. The indigenous Sami people have a distinct culture and history, which is not considered here, although their traditional music was, and still is, considered to be "ancient." 
"Norse" in the early- and mid-twentieth century they often refer to the Old Norse culture. ${ }^{2}$

\section{IN SEARCH OF THE EARLIEST STAGES OF MUSIC}

Present-day works of music history tend to reserve the earliest historical periods to specialist authors. Examples include the voluminous works about music history in Sweden and Norway, respectively, where chapters about prehistoric music are written by a music archaeologist (Lund 1994) and a musicologist specializing in early music and ethnomusicology (Ledang 2001). In the first half of the twentieth century musicologists often showed an awareness of both contemporary and ancient music. One such figure was Tobias Norlind (1879-1947), the pioneer of Swedish musicology. He covered a tremendously wide field, and published extensively on topics ranging from Beethoven, Wagner, Swedish and European music history to Swedish folk music, musical instruments, dance and folklore. Norlind never became a professor at any university, but he was awarded an honorary professorship by the Swedish government in 1939 (Bohlin 2004). He taught music history in several institutions, including the Music Academy in Stockholm, and was the director of the Music Museum in the same city, from 1919 onwards. Norlind wrote about ancient music several times, in articles, books, encyclopaedias etc. In his book about general music history (Norlind 1922) he does not mention Nordic music at all, stating in the preface that this subject does not belong in the book. He does, however, write about ancient music in general. The first chapter deals with the origins of music. Here, Norlind discusses various theories about the relationship between early language and music, chiefly from a philosophical point of view, with reference to Rousseau, Spencer, Montegut and others. The following chapters discuss the music of "primitive people" and early civilizations.

In Handbook of Swedish Music History (Norlind 1932) Norlind firstly covers the prehistoric period up to AD 1100, discussing

2 The Norse region is sometimes understood as the western parts of the Nordic region, i. e. Norway, Iceland, the Faeroe, Shetland and Orkney Islands, and Greenland. 
instruments, dance, and the functions that music served. According to Norlind, music appears in three forms-cultic, practical and artistic - of which the first two dominated in the earliest times. As the first evidence of music in Sweden, he lists archaeological finds of flutes, which, as in primitive cultures, were considered the most distinguished among cultic instruments. He continues with horns, made of animal horns and bronze, which served both cultic and practical functions. Harps are mentioned in the sagas and other Norse texts, in connection with heroic story telling. Norlind mentions (p.6) the mythical King Hugleik from Västergötland (late fifth-early sixth century), who loved music and singing, and the Old English poem Beowulf, which bears witness to the similar epic music culture. Still, Norlind seems to imply that this was music with a predominantly cultic function, and that Swedish music developed into "artistic" forms from the eleventh century onwards, as a result of cultural influences from the south and west.

Norlind also mentions the water spirit Neck (or "Nixie"), who was a musical deity during the Viking Age and the preceding centuries. The harp in the ancient texts was often connected to this mythical creature. Norlind suggests that melodies connected to Neck still preserved in Swedish folklore might be remnants of old cultic music from the Viking Age and even from the time of King Hugleik. This historic-folkloric approach was typical of Norlind, and was based on extensive research of Swedish folklore and folk music. Several publications present similar theories on the link between preserved folklore and ancient pre-Christian music. In an article from 1930 Norlind discusses the age of Swedish folk music explicitly (Norlind 1930). He discusses several musical forms: the call, dance songs, ballads and instrumental music, classifying them according to types that correspond to cultural layers. Norlind believes the call to be the oldest form. In his melodic classification of the call, the simplest type, consisting of a few tones in repeated patterns, is the oldest, while the more elaborated types with more tonal properties and cadences, is of a more recent date. The protoform is similar all over the world, with a universal distribution. Norlind audaciously dates these melodies, which survive in connection with cattle breeding at summer pastures, far back in time (Norlind 1930, 9): 
All these "calls" thus belong to such a primitive culture layer, that they certainly should be regarded as belonging to the time before the Christian era. If the call form in Sweden, despite all influences during the Viking Age, the Middle Ages and modern times, has kept its original form, which is still preserved in Europe in almost uninfluenced people, it has to be very ancient, and nothing prevents us from placing these melodies in the Stone Age. ${ }^{3}$

With regard to the other forms discussed in his article, Norlind makes similar evolutionary arguments. Indeed, from his early writings and throughout his entire scholarly life, Norlind was preoccupied with evolutionism (Jersild 2004), an important and widespread trend within the humanities after the influential work of Darwin. The forefathers of cultural evolutionism, Tylor, Morgan and Spencer, recreated Darwinian theories to fit human societies (Helliksen 1996, 11), the ideology of the last mentioned is often referred to as "Social Darwinism." The reasoning behind such thinking was to create a classification system facilitating the comparison of societies. In archaeology, evolutionary ideas gained particular popularity. Norlind may have been influenced by the important Swedish archaeologist Oscar Montelius (1843-1921), though we do not know anything about their possible acquaintance.

Based on Thomsen and other forerunners, Montelius elaborated the method of relative chronological dating. He described large quantities of artefacts, and grouped them into types on the basis of similarities between them. His goal was to develop a chronology for the prehistory of Europe. He was able to construct a chronological framework for the Neolithic Period, the Bronze

3 Swedish original text: "Alla dessa "rop" tillhöra således ett så primitivt kulturskikt, att de med säkerhet kunna anses vara före vår tideräkning. Har således ropformen i Sverige trots alla påverkningar under vikingatid, medeltid och nyare tid kunnat bibehålla urformen, som finnes kvar hos europeiskt i det närmaste opåverkade folk, måste den vare mycket gammal, och intet hindrar oss från att förlegga dessa melodier till stenåldern." 
Age and the Iron Age. In terms of method, Norlind did exactly the same as Montelius, since they both developed a typology designed for the dating of cultural artefacts. The difference is that where Montelius' types could be checked and controlled against safely dated key finds, the melodic types of Norlind are merely speculative. Norlind's evolutionary approach was not without comparison in this period. Notably within the German school of comparative musicology (Vergleichende Musikwissenschaft) identifying "primitive music" among living people that corresponded to earlier stages in human cultural development was a central aim. The origin of music was among the core issues within this school. Eric M. v. Hornbostel and Curt Sachs were the leading figures, centred around the Phonogramm Archive in Berlin. Sachs attempted to devise classification systems that fitted his theories on diffusion and evolution of musical instruments and musical forms. He was indeed more interested in the evolution of music than the factual history of music, as Albrecht Schneider has pointed out (Schneider 1986, 197).

Whilst Norlind had no direct connection to comparative musicology, even though he had studied in Leipzig, München and Berlin (Bohlin 2004, 7), another Scandinavian researcher had good relations with the Berlin community of researchers within ethnography and musicology. The Norwegian organist and explorer Christian Leden (1882-1957) studied in Copenhagen and Berlin, where he attended lectures by Hornbostel during the years after 1900. Inspired by ethnographical ideas, he decided to join an expedition to Greenland in 1909 in order to document the music and dance of the Inuit. ${ }^{4}$ The journey was a success, and on several later expeditions to Greenland and Canada he recorded music, took photographs and film, and collected artefacts, ${ }^{5}$ as the leading expert

4 The Inuit of Greenland were not considered to be part of the Scandinavian cultural community, at least not in the period covered by this article. Nevertheless, they belong to the geographical Nordic region.

5 Leden also visited South America, and collected folk music in Norway. He never received real academic credibility and remained an outsider, probably because of his extensive activities as a popular lecturer, in Europe as well as in USA. These activities took time from his scholarly 
on the music and dance of the Inuit. Leden's work exemplifies the basic ideas of comparative musicology. An important objective of his research was to achieve insight into the origins and early stages of music. In the so-called primitive cultures like the Inuit, such issues could be approached, since these people had lived uninterrupted by "civilization" for thousands of years, and hence could provide a window on to prehistoric music.

In his treatise on the music of the Smith Sund Eskimos (Thule area), published in 1952,6 Leden discusses the ideas behind his research. He states that ethnomusicological investigations might help us to enlighten the development of European music in prehistory (Leden 1952,18). Music is probably the oldest of all arts, its origins lying in the time before language, Leden asserts, maintaining that we cannot learn anything about such origins through any historical or material sources. The only possible way, then, is to look at the music of primitive people today. The Inuit were an especially interesting and instructive case, because they have lived in such isolation that some groups of them did not come in to contact with "civilized" peoples until our time. Leden emphasises that these people still live under ice age conditions, and the original culture of the Inuit is a Stone Age hunter and fisher culture (Leden 1952, 18). For Leden this was a guide and point of departure only; he did not devise any models for development in musical systems from the prehistorical level up to the present; he merely studied and described Inuit music as an example of a parallel with prehistoric music. He used his recorded material more to describe migration routes of the Inuit and racial relations

work. Leden never had regular work, and lived with his family in Germany and Norway, when he didn't travel. His book about his journeys with the Keewatin Eskimos, near Hudson Bay, Canada, resulted in the book Über Kiwatins Eisfelder (Leden 1927), which was translated into several languages.

${ }^{6}$ Leden lost the manuscripts for the two publications of his material from Greenland twice, first in a fire in his home town Steinkjer in 1940, then again when he lost a suitcase on a journey in 1943. This was the reason for the publication appearing as late as 1952. Two years later he finally published the material from Eastern Greenland (Leden 1954). 
between groups of Inuit in Greenland and Canada (as well as American Indians).

Although Leden regarded the Inuit as belonging to a Stone Age level of musical development, he did not disregard their music as simple or undeveloped. On the contrary he cherished their singing and dancing, and was impressed by their creative and artistic abilities and skills. Indeed, he regarded this early music of the Stone Age as something artistically advanced and valuable (Leden 1952, 19):

One could well assume that a people who in material terms are still at a similar stage of development as our Palaeolithic reindeer hunters at the end of the last European ice age, and who must fight so hard for their existence as the Eskimos have to, probably would have little opportunity to engage in music. However, on closer reflection their musical achievements show, both in terms of the complicated rhythms as well as in the technique of melodic structure and the manner of performance, an already advanced artistic development. That a people on a Stone Age level of development could create such a high composition and vocal technique as the Smith Sound Eskimos, suggests that the spiritual culture of mankind is as old as the material, and it also proves that a group of people can sing and compose long before they have developed melodic instruments and writing symbols. ${ }^{7}$

7 Original German text: "Man könnte wohl annehmen, dass ein Volk, welches in materieller Hinsicht noch auf einer ähnlichen Entwicklungsstufe stand wie unsere paläolitischen Renntierjäger am Ausgang der letzen europäischen Eiszeit, und das so schwer um das Dasein kämpfen muss, wie die Eskimos müssen, wohl wenig Gelegenheit haben würde, sich mit Musik zu befassen.

Ihre musikalischen Leistungen zeigen aber doch bei näherer Betrachtung, sowohl hinsichtlich des komplizierten Rhytmus als auch in der Technik des Melodiebaues und der Vortragsweise, eine schon vorgeschrittene künstlerische Entwicklung.

Dass ein Volk auf einer steinzeitliche Entwicklungsstufe eine so hohe Kompositions- und Gesangtechnik entwickeln konnte wie die Smith Sund 
Leden insisted on using the phonograph and film, because written transcriptions alone would not do justice to the characteristics of the music, and would be more biased. Leden was conscious about his ethnocentric tendencies, and consequently his chronocentric tendencies too, since his work might be seen as both an ethnography and prehistory of music.

\section{MUSICAL RELICS OF A GOLDEN AGE}

Since the music and folklore of the "people" was discovered and collected in the eighteenth and nineteenth centuries, it was important to discover the nation's oldest cultural forms that could be traced back to an ancient and lost "golden age." In the case of the Nordic countries, the heroic past was considered to be the Viking Age and the following centuries, a period when this part of the world experienced a flourishing prosperity, with extensive trade and a rich cultural life. Therefore, when not referring to a preChristian, undefined and mythical past, "ancient music" meant music from the period roughly from the ninth to the fourteenth century. The collectors and researchers did not know much about the actual music of this period, but they believed that present folk music provided them with remnants of it.

This way of approaching ancient music was in many ways the opposite of an evolutionism that looks at history as a progression from simple to advanced cultural forms. The emphasis here was rather on devolution (Ronström 1994, 25-26). Since the music of the present had declined, and could be traced through relics, it became a project to restore it, in line with its original form in the heroic past, ignoring the influences from other sources in the course of later centuries. Examples include instrumental music as well as ballads. In ballad research, one task was to restore small residues from large and heroic medieval forms. The long epic ballads that were considered cultural treasures were often given

Eskimos, deutet darauf hin, dass die Geisteskultur der Menschheit ebenso alt ist wie die materielle, und es beweist auch, dass ein Volk komponieren und singen kann, lange bevor es melodietragende Instrumente und Schriftzeichen entwickelt hat." 
unrealistic early datings. In Finland, the national epic Kalevala, written by Elias Lönnrot (1802-1884), was a compilation and recreation based on local traditional legends and songs, that was believed to stem from the ancient Finns (Ramnarine 2003, 36). Lönnrot's work with this epic, both "research" and "poetry", sought to link the present with a lost and brave past.

Along with poets and collectors of folk music and ballads, composers were also concerned with the process of restoring the ancient national heritage. The inter-war period witnessed a renewed nationalistic interest, where many composers were preoccupied with the expression of nationalism in their music, as an inheritance from the nineteenth century's nationalistic awakening in music. This was the case in all the Nordic countries, but notably in Finland (de Gorog 1989) and Norway (Vollsnes 2000). In Norway, David Monrad Johansen (1888-1974) was a central figure in this movement. In a description of the Norwegian tonal character in his work (Johansen 1925) he claims that this endeavour within music has much in common with the national language movement. Analogous to the Norwegian language, Norwegian music had been under the influence of several hundred years of foreign rule, and hence had lost contact with its ancient roots. Norwegian folk music, however, had maintained an original and authentic Norwegian character; therefore composers had to seek inspiration from national folk music in order to develop a genuine Norwegian tonal character.

Not only in polemic and ideology, but also in his musical works, Johansen demonstrated such ideas. In his important work Voluspaa from 1927 he takes the title from the first poem of the Poetic Edda, believed to have originated around the time of the introduction of Christianity to Scandinavia. The poem is among the most famous and important sources of Norse mythology. Titles by other composers of the time, such as Two Old Edda Poems, The Runic March, Balder's Dreams, Sigvat the Skald ${ }^{8}$ and others illustrate the

8 The Norwegian original titles are: To gamle Eddakvad, Runemarsjen, Baldurs draumar, and Sigvat Skald. 
tendency to embrace Norse heritage. ${ }^{9}$ Johansen was met with some critical voices, but in general this national movement gained popularity. Indeed it was, and still is, difficult to define the style in strictly musically terms. Nevertheless, this musical ideology is mentioned here to illustrate the notable desire for the old, ancient Norse culture.

The composer Geirr Tveitt (1908-1981) took these ideas to another level, both musically and in terms of research. Like Johansen and others, Tveitt believed that a Norwegian music tradition could be heard in present-day folk music. Moreover, he claimed that only music that had existed in total isolation, and protected from other European influences, could deserve the label "Norwegian" (Aksnes 2002, 228; Storaas 2008, 117). Tveitt developed a theoretical framework for his composition method, which in his opinion took an Old Norse tonal language as a point of departure. Specifically, he asserted that the tonal system based on major and minor keys was a relatively recent introduction from European urban culture. In his doctoral thesis Tonalitätstheorie des Parallellen Leittonsystems (Tveitt 1937) he introduced a tonal system built on four alleged Old Norse scales with names he had constructed himself. ${ }^{10}$ The thesis, in the German language, appeared to be extremely rigorous, difficult and inaccessible. It was not accepted, but Tveitt received some support from French and German composers and musicologists (Storaas 2008, 116).

Tveitt's ideas about a parallel tone system were not taken out of nowhere, or purely from his own imagination. The historical backdrop is the practice of parallel singing in fourths and fifths found in the Icelandic tvesong (Hornbostel 1930), which Tveitt tends to overestimate the importance and historical significance of. In an article from 1938 he accounts for the roots of the Norse music culture (Tveitt 1938, 64-65):

9 The term Norse was used in Norway since the nineteenth century as a broad term, denoting Nordic or Scandinavian medieval culture, mythology, history and language (Vollsnes 2000, 37).

10 'The scales RIR, SUM, FUM and TYR were inspired from a section in the poem 'Hávamál' from Poetic Edda. (Tveitt 1937, 5) 
Common to all truly Norse tone-feeling that we know of, is a symmetrical tone relation around the first and fifth scale steps. In this manner, the leading tone system is parallel. [...] We know from chroniclers that our Vikings sang in such a parallel system. But the Viking Age is by far the first thing we know about the high culture of Nordic Music. Through archaeological finds and excavations, we know that there existed a number of wind instruments, drums, and other instruments in the Stone Age, bearing witness to a high music culture among the Nordic peoples. Ten to twenty thousand years ago we thus had a bighly developed tone feeling. Even much further back for all we know, but this is what we know for certain. [ ...] A ten thousand years old flute found in Bornholm is inscribed with a sun cross. [...] A scientific and thorough study of these things teaches us that the Nordic race had a much older and greater music culture than any older people. ${ }^{11}$

Tveitt was right to assume that a music culture existed in Scandinavia by the Stone Age. ${ }^{12}$ Whether this culture was

11 Parts of the translation are taken from Aksnes (2002, 229). Norwegian original: "Felles for all verkeleg norrøn tonekjensla som me kjenner til er at det kring 1 ste og 5 te trinnet $i$ tonestigane er eit symmetrisk toneslektskap. På den visi vert leidetonesystemet parallelt. Me veit frå krønikeskrivarar at vikingane våre song $\mathrm{i}$ eit slikt parallelt system. Men vikingtidi er langtfrå de fyrste me veit um nordisk tonekunsts høge kultur.

Ved arkeologiske fund og utgravingar veit me at alt i steintidi fannst ei mengd med blåseinstrument, trommur og andre spelreide hjå dei nordiske folkeslag som vitnar um ein høg tonekunstkultur. For 10-20 tusund av ar tilbakars hadde me altso ei hogt utvikla tonekjensla. Ja, mykje lenger attende for det me veit, men dette kan me iallfall slå fast som visst. [...] Ei titusund års gamal fløyta funnen på Bornholm hev solhjulet påteikna. [...] Eit vitskapeleg og grundugt studium av desse tingi lærer at den nordiske folkerasen hev ein mykje eldre og større tonekunstkultur enn noko anna folkeslag."

12 Archaeological finds of musical relevance, safely dated to the Stone Age, include a neolithic flute from Sweden, as well as two potsherds from drums, found at Funnelbeaker culture (ca 4000 BC-2700 BC) excavations in Denmark (Lund 1981). The Bornholm flute mentioned by Tveitt is 
specifically Nordic and the instrument finds indicated a "high music culture" has nothing to do with historical facts, of course. Moreover, when Tveitt proclaims that a Nordic tone character existed between ten and twenty thousand years ago, he demonstrates that he has not checked any sources, since the inland ice entirely covered Scandinavia until about 10,000 BC. This was available knowledge in the 1930s. Tveitt's text is rather fictional, and demonstrates that ideology in this case overruns historical knowledge. He was inspired by the Neo-Heathenish movement in Norway, and his possible relations to the Nazi-ideologies before and under the German occupation have been subject to much controversy and are still unresolved and debated in Norway (Storaas 2008, Emberland 2009).

Irrespective of Tveitt's and other writer's positions, during the 1930s the Nazi ideologues cherished and utilized "Norse" culture in their propaganda about the Germanic heroic past. ${ }^{13}$ A unity between Nordic and Germanic prehistory was established when Nazi-supported research in Germany started to pay special attention to the Nordic Bronze Age culture. The connection between this lost empire and the Third Reich was the goal, and the lurs of the Bronze Age received a special symbolic value here, providing attractive visual as well as sounding qualities for this purpose (Lund 1987, Schween 2004). Specifically, the connection between the bronze lurs and Germany's past goes back to a lecture from 1911 by the German musicologist Oscar Fleischer (18561933), according to Joachim Schween (2004, 196-97).14 This was the start of the "Germanization" of the bronze lurs.

probably the find from Hammeren, which is among several archaeological flutes that are difficult to date (Lund 1981, 259). In any case, "ten thousand years old" is pure fiction.

13 Ideas about the Nordic, Germanic or Aryan race as the civilized race and its incarnation of the beautiful, the right and the good has, however, deeper roots in western thinking (Arvidsson 2009), and cannot be connected solely to National Socialism in Germany.

${ }^{14}$ Fleischer knew the leading archeologist Gustav Kossina (18581931) (Schween 2004, 196-197), whose nationalistic interpretations of prehistoric materials was later misused by Nazism. 


\section{BRONZE LURS AND EARLY POLYPHONY}

The first systematic treatment of the bronze lurs was completed by the Danish music historian Angul Hammerich (1848-1931), in an article from 1893 (Hammerich 1893). His research was followed by a range of modern uses of these magnificent instruments, to promote Danish nationalism. Since the majority of the approximately sixty lurs are found in Denmark, the nationalistic use of them has been most prominent there. Hammerich's scholarship encompassed the entire history of music. ${ }^{15} \mathrm{He}$ became the leader of the Music Museum in Copenhagen from its start in 1898, and was considered the leading authority of musicology in Denmark until his death in 1931. His publications and work at the museum were a great inspiration for other scholars in Denmark and the Nordic countries alike. In his history of music in Denmark (1921) Hammerich included early sources from other Nordic countries, because, as he says in the preface, a differentiation between Danish culture and that of its neighbours in the earliest times is elusive (Hammerich 1921, xi). The first chapter is devoted entirely to the Bronze lurs, starting with a celebration of these instruments that allow us "to follow the Nordic history of music much further back than we can in the music history of any other of the present civilized nations of Europe" (Hammerich 1921, 1). After this great opening, Hammerich sums up the archaeological finds, the instrument's technology and musical possibilities. He asserts that these instruments were found in pairs, and that the two lurs in one pair had similar ornamentation and technology, and that they were cast inverted to each other. This observation leads Hammerich to the question whether the Bronze Age people practised some kind of two-part playing. Despite his great enthusiasm for the lurs, in this work Hammerich develops his argument with care, probably because some Germans a few years earlier suggested the same idea in connection with their "far-fetched dreams of world domination

15 Hammerich's doctorate from 1892 was about music in the Court of Christian IV (Hammerich 1892), which covered the period from 1596 to 1648 . 
of Germanism" (Hammerich 1921, 11). ${ }^{16}$ He might be referring here to the above mentioned German musicologist Fleischer (Schween 2004, 196-97). Hammerich concludes his chapter with caution concerning this issue, stating that the only thing we can do is to suggest that Bronze Age people might have discovered harmony, not invented it (Hammerich 1921, 11). Despite Hammerich's caution in this text, he arranged concerts at the Music Museum with lur music played on original instruments, where the musicians played polyphonically. He also recorded lurs, released on phonogram in 1925 (Müller 1998, 12). The revival of the lurs, initiated by him, was aimed at both academia and the general public. It was met with some criticism, both in his own time and later. Cajsa S. Lund claims that Hammerich used an ethnocentric We/Us/Now-approach in his work, without accounting for the fact that the instruments come from a completely different cultural context than today (Lund 1987, 35). He tended to rely on modern musical standards, using experiments by players of contemporary brass instruments to evaluate the musical possibilities of the bronze lurs. In Hammerich's own time Curt Sachs was sceptical of Hammerich and his suggestion of two-part playing. Sachs was critical of Hammerich's use of ethnographic analogies, and held that instruments played in pairs do not necessarily imply two-part playing (Sachs 1913, 246; 1940, 113, 148).

Even if Hammerich applied modern standards of scholarship in his approach to bronze lurs and their musical potential, he was aware of ethnocentricity as a historiographical problem. Returning to the chapter on ancient music in his Danish music history, he discusses the problem that medieval chroniclers tended to use standards of their own time when they wrote about music from earlier and ancient times (Hammerich 1921, 13). Consequently, when we read a passage concerning antiquity written by the medieval chroniclers Snorre ${ }^{17}$ or Saxo, ${ }^{18}$ we do not learn about

${ }^{16}$ Hammerich died in 1931 and did not live to see the use of the lurs in the Nazi regime.

17 Snorre Sturlasson (1179-1241), Icelandic chronicler, wrote in Old Norse language.

18 Saxo Grammaticus (1150-1220), Danish chronicler, wrote in Latin. 
music in antiquity, but about the music as it was perceived in the eleventh-thirteenth centuries, Hammerich maintains (Hammerich 1921). In another place he draws attention to a text by Saxo, who in his Gesta Danorum from about AD 1200 erroneously places classical instruments such as kithara, lyra and sistrum in the hands of one of his ancient Norse heroes (Hammerich 1921, 18-19).

After a thorough review of a range of written and iconographic sources, Hammerich concludes his journey through ancient Nordic music with a discussion of polyphony (Hammerich 1921, 27-31). This time he does not commence with the bronze lurs, but from the English twelfth century writer Giraldus Cambrensis, who wrote that people in Northern England practise two-part-singing, and that this represents an old tradition in this area. Moreover, Giraldus' opinion is that this style of singing derived from Danes and Norwegians, introduced to England with the Viking settlements. Hammerich also credits the expert who first published this theory, the French-Belgian music theoretician François-Joseph Fétis (1784-1871), whose opinion that polyphony originated in Scandinavia, was based just on Giraldus' writings. Furthermore, Hammerich discusses the Orkney manuscript (ca. 1280) of the Hymn to St Magnus, Earl of the Orkneys. It was found and published some years prior to Hammerich's book (Kolsrud and Reiss 1913). The manuscript represents the first two-part song found in the Nordic region, ${ }^{19}$ consisting of voices in parallel thirds. This source might support the theory that Northern Europeans practised singing in two parts earlier than the rest of Europe. However, Hammerich does not assert the Nordic origin of polyphony, stating that the present state of knowledge does not allow for a solution to the question of origin.

The Norwegian composer and writer Gerhard Schjelderup (1859-1933) came to a more unequivocal conclusion on this question. Schjelderup wrote the first chapter of Norvegian Music

19 The Shetland and Orkney islands were a part of Norway from the ninth century to 1468 (Orkneys) and 1469 (Shetlands). 
History (Schjelderup 1921), ${ }^{20}$ published the same year as Hammerich's Danish music history (Hammerich 1921). Schjelderup, being a composer more than a scholar, devoted almost the entire chapter to the question of polyphony. He builds partly on Hammerich's research, but whereas Hammerich, despite a tendency towards nationalistic arrogance, discusses his sources with care, Schjelderup is more forthright. Schjelderup asserts that the bronze lurs belonged to a very highly ranked prehistoric culture, and that they were played in a style of primitive polyphony. Furthermore, he suggests that the Bronze Age people might have known the modern major triad, and perhaps even the minor triad (Schjelderup 1921, 3).

After making a connection from the bronze lurs to the Viking Age, Schjelderup continues with the same sources as those discussed by Hammerich (Cambrensis, Hymn to St Magnus), with the addition of some historical materials from Iceland. The so called tvesong, singing in two parts, often in parallel fourths or fifths (Hornbostel 1930), is known in historical manuscripts as well as in living traditions. Schjelderup points to the resistance against this kind of two-part singing, from Church authorities in Iceland as early as the fourteenth century. His opinion is that the tvesong represented an ancient and pre-Christian way of singing. Because it is preserved in Iceland, he holds that it was an Old Norse musical form belonging to Norway, since Iceland was populated by Norwegian settlers. Schjelderup's conclusion is that:

Fétis' hypothesis about the Nordic origin of polyphony thereby has gained a certain degree of reliability, if not to say full historical verification. Since neither Danish nor Swedish folk music show any traces of joy over singing in parallel fifths, which is found in Norwegian folk music and is also the only style found in Iceland, it would be tempting to suggest that the Norwegian people, in co-operation with the Celts, lay the ground for polyphonic music. Certainly this [polyphony] has,

20 The chapter is entitled "ældgammel tonekunst," meaning literally "very ancient tone art." The entire two-volume work was edited by Schjelderup and O. M. Sandvik. 
in its oldest form, been [sung] the same by Icelanders and Norwegians. In Norway foreign influences gradually took hold, whereas the ultra-conservative Iceland faithfully preserved its ancient traditions. The Norwegian Vikings travelled in Northern England, Scotland and Ireland, where polyphony definitely flourished, a long time before it became known in the rest of Europe. So far, we do not know anything about the ancient music of the other Nordic tribes. In other words, we might securely credit our ancestors, together with the Celts, the honour of having discovered the beanty and power of polyphony. Hereby our people have acquired an honorary place in the history of music. ${ }^{21}$

Despite these nationalistic ideas, Schjelderup was internationally oriented as a composer, mainly writing operas and orchestral works in a style inspired by Wagner's music. He had studied and lived most of his life in Germany, and had no important role in Norwegian music life apart from some years when he worked as a music critic, and he contributed towards the foundation of the Norwegian Composers Association. In several of his writings he was critical of nationalism in Norwegian music (Schjelderup 1976; Guldbrandsen

21 Schjelderup 1921, 9. Norwegian text: "Fétis hypotese om flerstemmighetens opstaaen i norden har derved vunnet en høi grad av sannsynlighet, for ikke at si fuld historisk visshet. ...

Da der hverken i dansk eller svensk folkemusik findes spor av den glæde over kvintrækker som vi finder i den norske folkemusik og som er eneherskende paa Island, kunde man fristes til at anta, at det norske folk i samarbeide med kelterne har lagt grunden til den polyfone musik. Utvilsomt har denne i sin ældste form været den samme hos islændere og nordmænd. I Norge trængte efterhaanden fremmed indflydelse ind, mens det stokkonservative Island trofast bevaret de ældgamle traditioner.

De norske vikinger færdedes i Nord-England, Skotland og Irland, hvor flerstemmigheten utvilsomt blomstret, længe før den var kjendt i det øvrige Europa. Om de andre nordiske stammers oldtidsmusik vet vi i al fald endu intet. Altsaa kan vi indtil videre med tryghet gi vore forfædre æren for sammen med kelterne at ha opdaget flerstemmighetens skjonhet og magt.

Derved har vort folk sikret sig en hædersplads i musikkens historie." 
2007). The unmistakable nationalistic ideas underlying the ancient music chapter of the Norwegian Music History appear somewhat paradoxical, illustrating the author's ambivalent position between nationalism and internationalism. In general, Schjelderup's text (Schjelderup 1921) conformed to the spirit of his time, when there was a strong national movement in Norway. However, it was not celebrated by all critics. The folk music collector and composer Catharinus Elling (1858-1942) savaged Schjelderup's chapter as well as the rest of the work in a separate book (Elling 1925). Elling goes through the text systematically, duly pointing out weaknesses and shortcomings. Examples include the assumption that an archaic tradition of two-part singing had existed in Norway and Iceland prior to and separate from the music of the Church, and that "joy over singing in parallel fifths" is found in Norwegian folk music. Elling criticizes Schjelderup's false conclusions and the fact that he tends to adjust his data to fit his theories. Elling's knowledge was substantial, but like Schjelderup he had no formal academic training. Later scholars also did not seriously entertain the idea that polyphony had a Nordic origin and that it was brought to the remainder of Europe by the Vikings. The German musicologist Manfred Bukofzer rejected the theory, replying, rhetorically, that "the wish is here father to the thought" $(1940,33)$.

\section{NORDIC INSTRUMENTS IN A WIDER CONTEXT}

One researcher in this period who deliberately integrated ancient music from Scandinavia within a European cultural context, was the Danish music historian and organologist Hortense Panum (1856-1933). After studies in Copenhagen and Berlin she travelled extensively in Europe, visiting libraries and archives. She wrote several books, of which the most important was the work about medieval stringed musical instruments and their forerunners in antiquity, published in three volumes in the years 1915, 1928 and 1931. The English version (Panum 1941) became a work of reference for its time, and made Panum acknowledged internationally. 22

22 The book was reprinted as late as 1971. 
The full title of the book was Stringed Instruments of the Middle Ages, their evolution and development. A detailed and comprehensive history, with illustrations, of the evolution of the medicval stringed musical instruments from their first appearance in the records of the earliest civilisations, through their gradual development in the Greek, Roman and Christian eras down to more recent times. Panum based the book on materials available to her at the time. The geographical scope was wide, with an emphasis on Europe, the Middle East, Egypt and Western Asia. However, the reason for the international approval of the work was that Panum introduced sources and instruments from Northern parts of Europe that were new to organological literature. Jeffery Pulver, who edited the English version, stresses that the instruments introduced by Panum, such as the Scandinavian tallharpa, nyckelharpa, fidla, bumle and langeleik, might allow for valuable comparisons that can open new lines of research (Panum 1941, vi).

In general, Panum's work is strictly organological. Panum goes straight into matters concerning the technology, classification and development of musical instruments, leaving out discussion of their function and significance. This was in line with the musicological trend of her time, which in general did not pay much attention to cultural context. Panum was considered to be an expert on musical instruments, especially ancient stringed instruments. Some of Panum's work is still acknowledged, especially her work on the harps and lyres of Northern Europe. Her term round lyre (Danish rundlyre), is still used to describe the rounded forms of lyres found in the iconography of medieval Scandinavia and elsewhere.

Panum lived in Copenhagen where she lectured at Louis Glass Music Academy and later at the Royal Danish Academy of Music. She was never employed or involved with the work at the Music Museum. The reason was probably her problematic relationship with the director Angul Hammerich (Jensen 1998, 46-49). She was a bit younger than him and he would not accept her, despite her great knowledge. Perhaps he felt his position threatened in some ways. This might have been especially difficult since she was a woman (Jensen 1998, 48). Their diverging views became apparent when Panum criticised the public concerts at the museum in a newspaper article, followed by Hammerich's response. Panum's opinion was that the concerts did not take the historical authenticity of the instruments seriously. According to Panum, Hammerich applied a fanciful approach (Jensen 1998, 48). Here, 
Panum appears to be before her time, advocating historical authentic performance.

Besides writing, Panum was involved in a project to reintroduce the ancient dulcimer (langspil) into the performance of Danish folklore. She based this work on models drawn from Norwegian langeleik tradition, which was still alive in Norway. Panum had travelled in Norway, and knew the instrument and its music (Panum 1920). However, her efforts to encourage interest in this instrument and introduce it into Danish schools did not succeed. One reason for this failure was, probably, that this instrument lacked national appeal, unlike the somewhat similar kantele, an instrument that became the national instrument of Finland. The kantele had a special role in the national epic Kalevala, ${ }^{23}$ and it gradually obtained and maintained its position as a national symbol in the first half of the twentieth century, a period when Finland needed national symbols to unite the nation. Throughout its history Finland had been subject to shifting influences from Sweden, Russia and Germany, and a national symbol was particularly necessary in this period (Torp 1998). In Denmark the situation was different, and they had no need for another national instrument, apart from the Bronze Age lurs.

Apart from her work with stringed instruments, Panum published texts about music history in general, and contributed to a music dictionary (Behrend and Panum 1924/1940). One year after her death, an article about all types of ancient and medieval Nordic instruments was published (Panum 1934). The book in which the article appears (Andersson 1934a) was an anthology focusing explicitly on Nordic music and musical instruments. It was a part of the comprehensive series Nordic Culture, a thirty-volume work co-edited between Sweden, Denmark and Norway. All these nations share important elements of culture and history, and the work allowed for a unified treatment. However, the successful Nordic cooperation seen here was not new in this period. The idea

${ }^{23}$ Kalevala's mythical hero Väinämoinen made a kantele from the jaws of a giant pike, and equipped it with strings from a virgin. Väinämoinen became a lord of nature and defeated his enemies by playing his kantele. (Torp 1998, 243). 
of Scandinavia or the Nordic region is not a new one, neither geographically, culturally nor mythically.

\section{THE NORDIC HERITAGE}

Scandinavia and the Nordic region are mentioned by Greek and Roman writers, usually in the form of short geographical descriptions. The terms used were Scanzia, Scandia and similar, besides Thule. A pioneer regarding the description of Nordic culture was the Swedish bishop Olaus Magnus (1490-1557). His main work Historia de Gentibus Septentrionalibus, usually translated as The History of the Nordic People (Magnus 1555) placed the Nordic region on the European map. Magnus was a patriotic author and described a proud, but also curious history. Amongst other things he mentioned the many sea monsters who inhabited the oceans surrounding Scandinavia. Despite Magnus' exotic picture of the Nordic area, his work built on a cultural unity, in the form of a common language, religion and history.

Among the Nordic political unions, some might be characterized as unbalanced in terms of power, for example those between Sweden and Finland (ca. 1250-1809) and DenmarkNorway (1380-1814). The Kalmar Union (1397-1523), a political union between Sweden, Denmark and Norway, was more politically balanced. A later ideological movement emphasizing the similarities rather than the differences between the Scandinavian countries, was the so called Scandinavianism (ca. 1830-1860). ${ }^{24}$ Later it flourished around the turn of the 19th-20th centuries, during the final stage of the political union between Norway and Sweden. The Nordic idea seen in music history and the other humanities, as well as the social sciences, was deeply rooted in political and cultural history. Nordic unity has usually co-existed with nationalism, even if some historical situations have produced

24 The Scandinavianists had much in common with nationalists, and they used much of the same rhetoric and symbols (Hansen 2008). The difference was that Scandinavia was a larger entity than the single nations. Several of the Scandinavists would also include Finland, since the Scandinavian language community also included parts of Finland. 
some tension between neighbouring nations. As seen frequently in this article, researchers with a national profile often had an interest in Nordic ideas, and vice-versa.

An example of a researcher with a notable Nordic profile is the Finnish scholar Otto Andersson (1879-1969). Andersson was born in the Swedish-speaking part of Finland, and he became an important figure in the movement of the so-called Finland-Swedish minority (Nyqvist 2007), as a collector, researcher, lecturer, conductor and more. He became professor of musicology and folk poetry research ${ }^{25}$ at Åbo Academy from 1926 to 1946, and was considered the foremost musicologist in Finland. Outside Finland he is mostly known for his work with ancient Nordic musical instruments, notably the bowed lyre and related instruments. As a result of a scholarship received in 1903 Andersson went to the Estonian island Ormsö with Swedish settlements, where he discovered the traditional bowed lyre called talharpa. He started to investigate this archaic and nearly extinct tradition, and found parallels in Finland (joubikeko), Sweden, Norway and the Shetlands. Andersson's comprehensive studies of these ancient instrument traditions resulted in a doctoral thesis Strakharpan (The Bowed-Harp) in 1923. It was published in Swedish, and later in English, edited and annotated by Kathleen Schlesinger (Andersson 1930). The English version led to Andersson's recognition by much wider audiences.

In Stråkharpan Andersson examines a wide range of ethnographic, archaeological, iconographic and written sources, demonstrating that the bowed lyre had existed in a large Nordic region, from Estonia and Finland to the Shetland isles. He held that the Nordic bowed lyre was related to similar instruments found in Ireland and the British Isles (the cruit and crwth), and he introduced the theory that the bowed lyre had a western origin, and that it had spread eastwards, arriving in Finland via Sweden. This theory met with some criticism, both in Finland and abroad. The preface to the English edition includes critical comments. Schlesinger writes here that she does not agree with Andersson and his ideas about the connection between Celtic instruments and the

${ }^{25}$ Folkdiktsforskning in Swedish. 
Scandinavian bowed lyre and its spread eastward (Andersson 1930, ix). Her objections are, however, "allowed to weigh in the balance when we take into consideration all the wealth of new material, both musicological and literary, laid before British and Irish archaeologists in music in this volume" (Andersson 1930). This is somewhat parallel to the reception of Panum's book when it was published in England; Panum's book was praised for the introduction of new materials previously unknown to British and other non-Scandinavian readers.

Andersson's theories also met with some criticism in Finland, notably from the musicologist Armas Väisäinen, who did not agree with the western origin suggested by Andersson as well as the thesis' proposed relationship between the bowed lyre and the kantele (Nyqvist 2007, 210-11; Väisänen 1923). Andersson's agenda was to reveal historical and cultural connections within the Nordic area. This was also due to his position as an advocate of the Swedish-speaking minority in Finland, although there was no particular tension between the two groups during the period in question. Finally, Andersson had the courage as an individual to promote his theories.

In later publications, notably in a posthumous article in The Galpin Society Journal (Andersson 1970), Andersson moderated his position, being more open to prevailing views of an eastern and southern origin of the bowed lyre, as well as for the introduction of bowing in European instruments. Nevertheless, he was enthusiastic about Nordic cultural connections, in this and other publications. Apart from his work with the bowed lyre, his ethnographic and historical research covered a diverse range of music-related sources. The above mentioned book edited by Andersson focusses explicitly on Nordic music and musical instruments (Andersson 1934a). His own introductory chapter on ancient music (Andersson 1934b) draws on a variety of sources, and discusses texts, iconographical and archaeological data regarding early Nordic music. Galdring, a still unresolved vocal practice, mentioned in Norse manuscripts in connection with religious rites and sorcery, is amongst the topics discussed. Andersson suggests that galdring might have borne some resemblance to the joik of the Sami (Andersson 1934b, 17-18). Like his forerunners Hammerich and Schjelderup, Andersson considers the question of polyphony in ancient sources (Andersson 
1934b, 19-22). He repeats previous arguments, but refrains from any bombastic conclusions.

Regarding the bronze lurs, Andersson comments on Sachs' criticism of Hammerich's musical use of these instruments (Andersson 1934b, 6). Hammerich suggested, notably through his concert performances, that Bronze Age players had a considerably advanced playing technique. Sachs attacked this view, emphasizing that the technical potential of instruments do not necessarily have such implications (Sachs 1913, 246). Sachs here drew upon a range of ethnographic analogies. Andersson agrees with Sachs on the point that we cannot prove that the Bronze Age people used all the technical and musical potential of their instruments. But on the other hand, according to Andersson it would be an error to insist that they certainly did not explore the potential of instruments. This is especially true since the bronze lurs are sophisticatedly built, suggesting that their builders had a considerable knowledge of acoustics, and that they would seek to develop this knowledge by musical experiments. In this instance one might object, with Sachs, that a certain Nordic or Nordic-Germanic bias is underlying the argument. In several instances of the academic as well as political uses of the bronze lurs, this was indeed the case. Nevertheless, the line of reasoning introduced by Andersson here should not be subject to such criticism.

\section{CONCLUSION}

The inter-war years were a formative period with regard to musicology in Scandinavia. Research on historical and ancient music was undertaken by pioneers with various backgrounds. Some were academics with formal training (Norlind, Hammerich, Andersson), some had a semi-formal training (Panum, Leden), while others were composers (Tveitt, Schjelderup). Most of the studies introduced in this article used ethnographic-historical approaches. None of the pioneers were archaeologists, ${ }^{26}$ but a few,

26 Several archaeologists contributed to the history of ancient music with the publication of important finds of musical instruments and sound tools in this period. These individuals have not been considered in this 
notably Andersson and Panum, were to some extent concerned with archaeological sources.

In this period, the institutionalization of musicology began. Sweden created lectureships in Stockholm in 1926 and Uppsala in 1928 (Nyqvist 2007, 178). Denmark appointed its first professor of musicology in 1926 (Nyqvist 2007, 178). In Finland the first lectureship in the history and theory of music was established in Helsinki university already in 1900 (Nyqvist 2007, 177). Norway, at the other end of the scale, established its first musicological chair at the University of Oslo as late as 1956 (Nyqvist 2007, 180). These differences are partly reflected in research about ancient music. The Norwegian contributions were written by people with less formal training, which is also apparent in their work. Another variable is nationalism. In Sweden and Denmark the interest in nationalistic ideologies was slightly diminished during the first half of the twentieth century, whilst Norway and Finland were still young nations that felt the need to build up their national selfconsciousness. Whilst the nationalistic tendencies within this field of research did exist both in Sweden and Denmark, it was definitely more prominent in Norway. This tendency might also be due to the formative stage of musicology and related disciplines in Norway. In Finland, the situation is more complex, since the prominent scholar Andersson represented the Swedish minority there. ${ }^{27}$

Norse or Nordic identities were often parallel or even equivalent to national identities. Furthermore, Germanic identities could also be included within national ones. For example, a bronze lur excavated in Denmark could at the same time be treated as a Danish, a Norse, a Nordic and a Germanic musical instrument.

The investigation of music history, in a similar way as the investigation of folk music and ballads, was extremely preoccupied with the distant past. It was important to find the oldest musical forms, and to date them as early as possible. This tendency should

article. A survey of archaeological contributions to the prehistory of music in Scandinavia is given by Lund in this volume.

${ }^{27}$ This article has not considered research on ancient Finnish music written in Finnish. 
be understood in the context of nation-building processes of this period. Moreover, two contradicting ideas appear in this historiography, that of evolution and devolution. While evolutionism presupposes development from primitive to advanced cultural (and musical) forms, devolutionism is its opposite, asserting that only the present makes remnants of earlier and ancient high cultures (and music) apparent. An ideology about Nordic ancient music as the leading and prevailing music in Europe since the Bronze Age was sometimes explicitly expressed, and at other times only implicit, for instance in the theory of a Northern origin of polyphony.

Despite the variety of backgrounds represented by our authors, the overall impression is that these pioneers approached their sources basically from an organological and musicological point of view, focusing more on artefacts than cultural contexts. However, these individuals collected substantial materials. They were deeply committed to their work, in view of the fact that they did not have the same easy access to materials as we have today. Their interpretations, drawing on a wide range of sources, were often brave. Many of the pioneers' works are forgotten today, but much of their work forms the basis of contemporary established knowledge. These forerunners in the study of music history, musical instruments and ancient music should not be forgotten and treated as insignificant voices from a long outdated paradigm, which seems to be the tendency within present scholarship. Instead, we should turn to these pioneers and read their work, and try to understand them in their historical context. As researchers today we build on their achievements, despite the fact that a critical perspective on their work is paramount.

\section{BIBLIOGRAPHY}

Aksnes, H. (2002). Perspectives on Musical Meaning. A Study Based on Selected Works by Geirr Tveitt. Doctoral thesis, University of Oslo.

Andersson, O. (1930). The Bowed-Harp: A Study in the History of Early Musical Instruments, ed. Kathleen Schlesinger. London: W. Reeves. (Original in Swedish: Sträkharpan. En studie $i$ nordisk instrumenthistoria. Stockholm: Föreningen för svensk kulturhistoria, 1923). 
Andersson, O. (ed.) (1934a). Musik og musikinstrumenter. Nordisk Kultur 25, ed. O. Andersson. Stockholm: Bonnier.

(1934b). "Nordisk musikkultur i äldsta tider." In: Andersson 1934a: 3-23.

Andersson, A. (1970). "The Bowed Harp of Trondheim Cathedral and Related Instruments in East and West." The Galpin Society Journal 23: 4-34.

Arvidsson, S. (2009). "Germania. Noen hovedlinjer i forskningen om fortidens germanere." In: Jakten på Germania. Fra nordensvermeri til SS-arkeologi, ed. T. Emberland and S. Fure. Oslo: Humanist: 11-34.

Behrend, W. and Panum, H. (1924/1940). Illustreret Musikleksikon. København: Aschehoug.

Bohlin, F. (2004). "Tobias Norlind - en kort biografi." In: Om Tobias Norlind, en pionär inom musikforskningen, ed. F. Bohlin. Lund: Tobias Norlind-samfundet för musikforskning: 7-12.

Bukofzer, M. (1940). "Popular polyphony in the Middle Ages." The Musical Quarterly 26.1: 31-49.

de Gorog, L. (1989). From Sibelius to Sallinen. Finnish Nationalism and the Music in Finland. New York: Greenwood Press.

Elling, C. (1925). Strobemarkninger til vor Musikhistorie. Oslo: Johannes Bjørnstad.

Emberland, T. (2009). "Hvilken Pangermanisme? Ragnarokkretsen, SS og Ahnenerbe." In: Jakten på Germania. Fra nordensvermeri til SS-arkeologi, ed. T. Emberland and S. Fure. Oslo: Humanist: 227-43.

Guldbrandsen, E. (2007). "Det 'norske' som noe fjernt eller tapt. Schjelderups ambivalente Norges-symfoni." Studia Musicologica Norvegica 33: 7-32.

Hammerich, A. (1892). Musiken ved Christian den Fjerdes Hof. København: Hansen.

(1893). "Studier over Bronzelurerne i Nationalmuseet i Kjøbenhavn." In: Aarboger for nordisk Oldkyndighed og Historie 8: 141-90.

- (1921). Dansk Musikbistorie indtil ca. 1700. København: Gads.

Hansen, T. I. (2008). Et skandinavisk nasjonsbyggingsprosjekt: Skandinavisk Selskab (1864-1871). Masters thesis, history, University of Oslo. 
Helliksen, W. (1996). Evolusjonisme i norsk arkeologi. Varia 37. Oslo: Universitetets Oldsaksamling.

Hornbostel, E. M. v. (1930). "Phonographierte isländische Zwiegesänge." In: Deutsche Islandforschung 1930, ed. W. H. Vogt and H. Spethmann. Breslau: Hirt: 300-20.

Jensen, H. Ø. (1998). “ 'Disse Monumenter ere jo ikke Stene.' De tidligste historiske koncerter på Musikhistorisk Museum." In: Musikkens tjenere. Instrument — forsker musiker, ed. M. Müller and L. Torp. København: Musikhistorisk Museum/Museum Tusculanums Forlag: 33-69.

Jersild, M. (2004). "Norlind, balladmelodierna och evolutionismen." In: Om Tobias Norlind, en pionär inom musikforskningen, ed. F. Bohlin. Lund: Tobias Norlindsamfundet för musikforskning: 55-66.

Johansen, D. M. (1925). "Die nationalen Werte in der Musik." In: Deutsch-Nordisches Jabrbuch für Kulturaustausch und Volkskunde: 72-83. [Originally a lecture from 22. 5. 1925; published in Aftenposten 5. 7, 6. 7. and 8. 7. 1925 under the title 'Nationale verdier i vor musikk.']

Kolsrud, O. og Reiss, G. (1913). Tvo norrone latinske kvade med melodiar. Utgjevne fraa Codex Upsaliensis C 233. Videnskaps-selskapets skrifter 2, Hist.-filos. klasse. 1912. No. 5. Kristiania: J. Dybwad.

Ledang, O. K. (2001). 'Forhistorisk tid, Fra lurblåst til klokkeklang.' In: Norges Musikkhistorie 1, ed. A. O. Vollsnes. Oslo: Aschehoug: 13-55.

Leden, C. (1927). Über Kiwatins Eisfelder. Leipzig: F. A. Brockhaus (English version: Across the Keewatin Icefields. Winnipeg 1990).

- (1952). Über die Musik der Smith Sund Eskimos und ibre Verwandtschaft mit der Musik der amerikanischen Indianer. Meddelelser om Grønland udgivne af kommisionen for videnskabelige undersøgelser i Grønland 152, 3. Copenhagen: C. A. Reitzel.

(1954). Über die Musik der Ostgrönländer. Meddelelser om Grønland udgivne af kommisionen for videnskabelige undersøgelser i Grønland 152, 4. Copenhagen: C. A. Reitzel. 
Lund, C. S. (1981). "The archaeomusicology of Scandinavia." World Archaeology 12.3: 246-265.

(1987). "The 'phenomenal' bronze lurs: Data, problems, critical discussion." In: Second Conference of the ICTM Study Group on Music Archaeology II, The Bronze Lurs. Publications issued by the Royal Swedish Acadamy of Music 53, ed. C. S. Lund. Stockholm: 9-50. (1994). "Forntiden." In: Musiken i Sverige 1, ed. L. Jonsson.

Stockholm: Fisher: 21-38.

Magnus, O. (1555/1972). Historia de gentibus septentrionalibus ["The History of the Nordic People”]. København: Rosenkilde and Bagger.

Müller, M. (1998). "Angul Hammerich. Manden bag Musikhistorisk Museum — og dets direktør fra 1898 til 1931.” In: Musikkens tjenere. Instrument - forsker - musiker, ed. M. Müller and L. Torp. København: Musikhistorisk Museum/Museum Tusculanums Forlag: 9-32.

Norlind, T. (1922). Allmän musikhistoria frän äldre tider till närvarande tid. Stockholm: Wahlström \& Widstrand.

(1930). “Hur gammal är den svenska folkmusiken?” Svensk tidskrift för musikforskning 1930: 5-36.

(1932). Handbok $i$ svenska musikens historia. Stockholm:

Nordiska musikförlaget.

Nyqvist, N. (2007). Från bondson till folkmusikikon. Otto Andersson och formandet av "finlandssvensk folkemusik." Åbo: Åbo akademi.

Panum, H. (1920). Langeleiken. Hamar.

(1934). "Middelalderens Musikinstrumenter." In: Andersson 1934a: 50-69.

(1941/1971). Stringed instruments of the Middle Ages. Their

Evolution and Development. Translated from the Danish.

Revised and Edited by Jeffrey Pulver. London: W. M. Reeves. [Original Danish version: Middelalderens strengeinstrumenter og deres forlobere $i$ oldtiden. 3 vols., 1915, 1928 and 1931. København: Lehmann \& Stage.]

Ramnarine, T. K. (2003). Ilmatar's Inspirations. Nationalism, Globalization, and the Changing Soundscapes of Finnish Folk Music. Chicago: The University of Chicago Press. 
Ronström, O. (1994). "Inledning." In: Texter om svensk folkmusik frän Haeffner till Ling, ed. O. Ronström and G. Ternhag. Stockholm: Kungl. musikaliska akademien: 9-26.

Sachs, C. (1913). Real-Lexikon der Musikinstrumente. Berlin: Julius Bard.

(1940). The History of Musical Instruments. NewYork: W. W. Norton.

Schjelderup, G. (1921). “Ældgammel tonekunst.” In: Norges musikhistorie, ed. G. Schjelderup and O. M. Sandvik. Kristiania: Eberh. B. Oppi: 1-9.

- (1976). Gerhard Schjelderup. En norsk operakomponists liv og virke. Oslo: Gyldendal.

Schneider, A. (1986). "AРХАIO $\Lambda$ ОГЕ $\Omega$ : Some comments on methods and sources in music archaeology." In: Second Conference of the ICTM Study Group on Music Archaeology I, General studies. Publications issued by the Royal Swedish Academy of Music 53, ed. C. S. Lund. Stockholm: 195224.

Schween, J. (2004). "Verehrt und mißbraucht - Zur Rezeptionsgeschichte der bronzezeitlichen Luren im 19. und 20. Jahrhundert." In: Studien zur Musikarchäologie IV, OrientArchäologie 15, ed. E. Hickmann and R. Eichmann. Rahden/Westf., Marie Leidorf: 193-220.

Storaas, R. (2008). Mellom triumf og tragedie. Geirr Tveitt - ein biografi. Oslo: Det Norske Samlaget.

Torp, L. (1998). "Bliver man skotte af at spille på sækkepibe? Om begrepet nationalinstrument." In: Musikkens tjenere. Instrument - forsker - musiker, ed. M. Müller and L. Torp. København: Musikhistorisk Museum/Museum Tusculanums Forlag: 231-59.

Tveitt, G. (1937). Tonalitätstheorie des parallelen Leittonsystems. Oslo: Gyldendal. (1938). "Norrøn tonekunst." Ragnarok 4: 63-67.

Vollsnes, A. O. (ed.) (2000). Norges Musikkhistorie 4. Oslo: Aschehoug.

Väisäinen, A. O. (1923). "Jouhikanteleen alkuperä. Otto Andersson: 'Stråkharpan'.” Suomen musiikkilebti 7: 3-16. 



\title{
Music ARCHAEOLOGY IN SCANDINAVIA, 1800-1990
}

\author{
CAJSA S. LUND
}

In 1797 the first discovery of Scandinavian Bronze Age horns, the so called lurs, was made in Denmark. Naturally, a great deal of attention has been devoted to these impressive instruments, which are approximately three thousand years old. Up to the 1960s, these lurs were usually discussed in Scandinavian archaeological specialist literature as if they were the only preserved remnants of prehistoric music in Northern Europe. Several sporadic, pioneering studies of other sound-making instruments were also completed early on. However, it was not until the 1970s that a more systematic approach to research on music and other "cultural sounds" in Scandinavia's prehistory began, under the name "music archaeology." What had started with a bandful of international individuals, including the author, soon grew into a group of researchers, which have laid the foundation for the field of music archaeology today. The history of the term "music archaeology" is summarised in an appendix.

To Ellen Hickmann, friend and colleague

"The Phenomenal Bronze Lurs" was the heading, with ironic understatement, of a paper in 1987 stating that, although studies of music in Scandinavia's prehistory have appeared occasionally since the middle of the nineteenth century, the so called lurs were for more than one hundred and fifty years regarded as almost 
synonymous with prehistoric music in the Scandinavian countries (Lund 1987, 9). It was not until the 1970s that a more comprehensive and systematic approach to research began-and this was in Sweden-on music and other non-linguistic sounds (even whole soundscapes) in prehistoric societies in Scandinavia. This was thus a field to which relatively sporadic attention had been devoted earlier, apart from the bronze lurs. The field was given the name "music archaeology," in Swedish musikarkeologi, a term that people in professional circles in Sweden thought was newly coined in their country. Music archaeology (the very first English version was "musical archaeology") was soon given its own platform in Stockholm. This meant, among other things, greater possibilities for the active creation of international contacts. Thus, early on Sweden became an important meeting place for the relatively few researchers from abroad who at that time combined musicology and prehistoric archaeology. Even the term "music archaeology" itself started to be introduced to the world at large.

This paper is a summary of the background and development of music archaeology in Scandinavia up to around 1990, albeit with a focus on Sweden, including the history — as known to the present author-of the term "music archaeology" and its international variants. For a more Pan-European survey of music archaeology from a historiographical perspective, with references also to nonEuropean high Classical cultures, I would like to refer the reader to an article by J. V. S. Megaw (Megaw 1988, 343-53), Albrecht Schneider's comprehensive study (Schneider 1986, 195-224), and to basic articles by Ellen Hickmann (Hickmann 1983/84, Hickmann 1985, Hickmann 2006). Let me add here, that Scandinavia in this paper means the Nordic countries Sweden, Denmark and Norway. Scandinavia's prehistory is customarily divided into the Stone Age (ca. 10,000-1800 BC), the Bronze Age (ca. 1800-500 BC) and the Iron Age (ca. 500 BC-1050 AD). The so called Viking Age (ca. 800-1050 AD) is the last period of Scandinavia's prehistory. The boundary between prehistoric times and the next period, the Middle Ages, is naturally flexible. Standard archaeological practice places it at 1050 AD for South Scandinavia up to and including the counties of central Sweden. In the more northern parts of Scandinavia, the transition occurred much later. 


\section{A GRAND OVERTURE}

In the year 1797 a letter was received at the Royal Treasury in Copenhagen stating that a farmer had found six curved metal horns in a bog called Brudevaelte (Fig. 1). Six years later (1803) it was reported that two similar metal horns had been found in another bog in Denmark. The horns turned out to be cast in bronze and were assumed to be very old. The Danish archaeologist C. J. Thomsen (who proposed the Three-Age system, for which he is remembered internationally), was the first person who could date these, and a number of other bronze horns that were found in the early nineteenth century, to the period he called the Bronze Age. And in 1836 he also gave them a name: lur (Thomsen 1836). Thomsen was clearly inspired by the ludr of old Islandic literature, an occasionally mentioned but hitherto unidentified wind instrument (Broholm 1965, 12).

At the end of the nineteenth century a total of twenty five lurs had been found. Researchers were thus confronted early on with a whole group of ancient instruments that seemed to reveal an unexpected, highly developed music culture of our early ancestors about three thousand years ago, at the same time that they bore witness to a high degree of skill in the art of casting bronze. Amongst the great variety of archaeological finds they stand out in terms of both size and quantity. They were well preserved; some could still be played, and trombonists could demonstrate their excellent technical possibilities as performing instruments. In addition, rock carvings representing the instruments which date from the same period were preserved.

Naturally a great deal of attention was devoted to the lurs in monographs as well as in extensive articles, including a work by the Danish music historian Angul Hammerich (1893), which was translated into both French and German (Hammerich 1893). Later Hammerich writes in the publication Dansk Musikbistorie (here freely rendered from the Danish):

Like a fanfare, Denmark's music history starts out with the large and beautiful Danish lurs from the Bronze Age. Indeed, a grand overture. With the lurs we can trace Nordic music history further back than we can in the case of any other current civilised European nation. (Hammerich 1921, 1-2) 


\section{The Sound of ARCHAEOLOGY}

When the present author in the early 1970s-having been active as a musician-began to study prehistoric archaeology at the University of Lund, it soon became apparent that methodological studies of music and other sound activities in prehistoric Scandinavia for the most part seemed to be quite a neglected field on the archaeological map, with the exception of the bronze lurs. My supervisors as well as my fellow students encouraged me in my choice of subject for my undergraduate thesis, on prehistoric musical instruments in the Nordic countries (Lund 1972), albeit after some hesitation. This is due to "the non-archaeological character" of the subject-archaeology works with observable traces of humans, and music can certainly not be dug up physically out of the ground; also, there seemed to be very few finds of musical instruments apart from the lurs. My hypothetical point of departure was that different kinds of musical instruments and other sound tools from Scandinavia's prehistoric periods lay overlooked and/or misinterpreted in the storehouses of the archaeological museums. The fundamental idea was that these presumed "hidden" material traces of ancient music and sound activities were not primarily musical instruments in our conventional Western sense, but objects used for various sound productions e.g. signalling, hunting calls, and in magical, and cultic contexts.

This approach, which was influenced by ethnomusicology, opened up new possibilities of interpretation regarding archaeological find materials in the selection of museum collections that I inventoried. Is the bone tube with bevelled ends (registered as an artefact with unknown function) a shaft, a bead, an amulet, a needle case, an animal call, or something entirely different? At the same time this approach gave rise to an important problem: how can one substantiate, or in any case corroborate, the assumption that a particular archaeological artefact, or a whole group of similar artefacts, with unknown or unclear function, has been utilised for sound production, primarily or secondarily? The thesis was a step toward a more systematic and comprehensive multidisciplinary research in the field of prehistoric music in the Nordic countries, with a focus on southern Scandinavia. Its direction was then, and still is, markedly organological in so far as its orientation is to a large extent concerned with the primary sources of the field, viz. questions dealing with finds of musical instruments and other 
sound tools, certain or possible (see Fig. 2). The field was at first given the English name "musical archaeology," later on "music archaeology" (and in Swedish musikarkeolog $)$, in 1974 by the staff of the Music Museum, Stockholm (Larsson 1974a, 4; Larsson 1974b, 3), ${ }^{1}$ but then without any cognizance of the fact that the term had been used occasionally a few times already in the nineteenth century, in Sweden for example in 1880 (Södling 1880, 203). On the known history of the term as such, see the Appendix below.

\section{HISTORICAL BACKGROUND PRIOR TO THE 1970s}

\section{Pioneers}

As previously mentioned, the bronze lurs have held a central position in researchers' as well as in the general public's conceptions of prehistoric musical life in the Nordic countries, since the early nineteenth century. For the latter-day role of the bronze lur as a national and political symbol, see Fig. 3. However, sporadic studies of prehistoric sound instruments other than the bronze lurs were also completed early on, e.g. a blowing horn made of an ox horn with bronze additions, found at Barva, Sweden, dated to the early Iron Age (Hildebrand 1881; see Fig. 4), early stringed instruments (Panum 1915, 1928, 1931), ${ }^{2}$ early bells and cow bells (Lithberg 1914), Norwegian Iron Age iron rattles (rangler, see Petersen 1917), the lyre bridge found at Broa on Gotland, Sweden (Salin 1922), a wooden megaphone found at Kvalsund, Norway, dated to the Iron Age (Shetelig and Johannessen 1929), and the so called "Balkåkra drum," found at Balkåkra, Sweden, dated to the early Bronze Age (Nerman 1937). Mention should also be made here to a study in Finland, on Finnish Iron-Age iron rattles (Hackman 1938). The studies on early stringed instruments were authored by a music historian and organologist (Panum 1915, 1928, 1931) and the early bells and cow bells by a folklorist

1 The primary "inventor" of the term was Sven Berger, research assistant at the museum.

2 For more biographical information on Panum, see Gjermund Kolltveit's paper in this volume. 
(Lithberg 1914), while the other studies were by archaeologists. Let me also mention a few early far-sighted archaeological interpretations of Stone Age artefacts, all found in Sweden, as possible musical instruments: whistles of antler (Nilsson 1838, 79), possible panpipes of bone (Nihlén 1927, 126), and whistles of wildboars' tusks (Rydh 1931, 37).

Carl Erik Södling (1819-1884), a Swedish researcher of folk music, and also a drawing teacher, amongst other things, was in his own way a pioneer. He seems to have been the first in the Nordic area to have used the term "music archaeology" (musikarkeologi in Swedish)—for example in a speech of 1880 at a meeting of the Swedish Antiquarian Society. Södling claims there that music and archaeology belong together, whatever people say, referring to the Belgian musicologist François-Joseph Fétis. At another meeting of this society (1876) Södling made an appeal to the members (several were prehistorians) that each of them should study old sound instruments (tonverktyg in Swedish; see Södling 1880, 203; Södling 1876, 133; Fétis 1869). Södling does not define what he means with the terms "music" and "archaeology" but, in my opinion, he indicates in his speeches that studies of music in ancient times must be undertaken by musicologists and archaeologists in cooperation - and this was quite a radical approach in the 1870s1880s. When Södling asked to lecture at the Archaeological Congress in Stockholm in 1876 his request was denied by the leading archaeologists of the time, their reason being that music was not part of archaeological research (Moberg 1951, 41). Later (1951) it was maintained, and doubtless very rightly so, that Södling's too "Rudbeckian" and grandiose accounts must "...have made a comical impression on the archaeologists and professional antiquarian researchers present" (Moberg 1951, 41). ${ }^{3}$

3 Olof Rudbeck, a seventeenth century Swedish world famous professor and natural scientist in Uppsala, held that Sweden was the abode of the gods, the origin of all important peoples and the most ancient seat of learning and culture. These views usually go under the name of "Göticism” or "Rudbeckian spirit." 


\section{The productive 1940s}

In 1947, the legendary Swedish music historian and organologist Tobias Norlind (1879-1947) published a compilation and discussion of what he then knew about prehistoric instruments in Sweden (Norlind 1947). This was based on an unconventionally broad outlook on music. There are clearly shortcomings in his knowledge and understanding of the archaeological source material. Apparently, he did not try very hard to work together with archaeologists of his time, with regard to the artefacts under discussion. It should be mentioned here that Tobias Norlind was in many ways a pioneer in Swedish musicology, sometimes called Sweden's Curt Sachs. He was also director of Musikhistoriska museet (today the Music Museum) in Stockholm. He was succeeded in this position by another esteemed researcher, the ethnomusicologist and organologist Ernst Emsheimer (1904-1989).

In 1948 a Swedish student, Carl Gösta Widstrand, later to become an internationally active music anthropologist, submitted an undergraduate thesis on prehistoric musical instruments at a seminar in prehistoric archaeology at Stockholm University. The thesis dealt with an assortment of musical instruments (in the more conventional sense of the word) from a European perspective (Widstrand 1948). According to Widstrand, both the professor and his fellow students were indifferent to his field of research. The thesis itself, which was the first of its kind in Sweden, was also soon forgotten. There were apparently only two copies of it, and in the 1980s I had the pleasure of receiving a copy from Widstrand himself, turned yellow and mangled after storage amongst miscellaneous "trash" in his garage. Carl Gösta Widstrand and Tobias Norlind worked at the same time in the same field, but they had no personal contact with each other. And this-according to Widstrand himself-was due to the fact that he was just a young student who did not have the courage to contact Norlind.

Yet another Swedish project in the field of prehistoric music was carried out at this time, viz. the Swedish archaeologist Andreas Oldeberg's comprehensive study of the bronze lurs, with a focus on the lurs found in Sweden (Oldeberg 1947). In the same period, the Danish archaeologist Hans Christian Broholm was working in Copenhagen on his extensive monograph on the bronze lurs, which would become (and still is) a standard work on the lurs (Broholm, Larsen and Skjerne 1949). Broholm and Oldeberg were 
in close contact with one another. For his publication in 1949, Broholm commissioned the art work caster William P. Larsen, who for several years had worked on the restoration of the Danish lur finds, and the music historian Godtfred Skjerne, as collaborators and contributors. With this co-production, Broholm initiated the first real interdisciplinary effort in Scandinavia with regard to prehistoric music. Godtfred Skjerne's contributions to the publication are in many ways remarkable, in particular his exemplary attempts to play the bronze lurs that he, together with experts in acoustics, carried out and analysed, and his nuanced interpretations of the lurs' social role and their use as a musical instrument. Skjerne's contributions contain, in addition, a survey of a selection of prehistoric instrument finds from an international perspective and, interestingly, a comprehensive section on prehistoric bronze rattles, based on the rattles attached to the bronze lurs (Skjerne 1949, 71-129). ${ }^{4}$

\section{The 1950s and 1960s}

From the 1950s onwards five different, more or less extensive, surveys of prehistoric music/musical instruments in Scandinavia were completed. All of these studies were written by musicologists: Angul Hammerich (1921, 1-31; except for the bronze lurs, he writes about relevant early written sources, i.e. medieval Nordic sagas), the Finnish-Swedish Otto Andersson (1934, 1-23; various finds of musical instruments and Nordic as well as Roman and Arabic early written sources) and-as previously mentionedNorlind 1947; Widstrand 1948; Skjerne 1949, 71-129; see also Andersson 1930). ${ }^{5}$

Two large articles on instruments from an archaeological perspective were written in the early 1950s, namely by the Swedish archaeologist Andreas Oldeberg on bone flutes and animal horns (Oldeberg 1950), and by the Danish archaeologist Sigvald Vestergaard Nielsen, also on bone flutes (Vestergaard Nielsen

4 In 1931 Skjerne succeeded Hammerich as director of the Music Museum in Copenhagen.

${ }^{5}$ For more biographical information on Hammerich, Andersson and Norlind, see Gjermund Kolltveit's paper in this volume. 
1951). Moreover, the German musicologist Herman Moeck published a comprehensive study on early block-and-duct flutes in Scandinavia (Moeck 1955). A study by Walter Wiora (Wiora 1961), devoted to the great Swedish musicologist Carl-Allan Moberg, may also be mentioned here. Interesting interpretations of isolated artefacts are found in the writings of the archaeologists Svend Jørgensen (Jørgensen 1956, 30-on the early Stone Age "Kongemose bullroarer" in Denmark) and especially the Swedish archaeologist Gunborg Ohlson (Ohlson 1967, 31-37) in her works on grave material from the Stone Age on Gotland (possible scrapers, rattles and whistles of bone).

\section{Summary}

An examination of the archaeological and musicological literature published in Scandinavia before the 1970s reveals many discoveries and insights about prehistoric musical instruments and other sound tools. Why did these studies not provide a stimulus to a more coherent research tradition? There are probably several concurrent reasons for this. Studies were spread out amongst different publications. The individual studies were so spread out that it was not possible to survey them from one vantage point. There was a lack of interdisciplinary cooperation. There was apparently no serious collaboration between prehistorians and music historians in the form of joint projects or jointly formulated problems. ${ }^{6}$ The international popularisation of the "phenomenal bronze lurs" as Scandinavia's, indeed even Europe's, oldest musical instruments, by Angul Hammerich and others, might have been a reason why researchers in general were not concerned with more holistic questions about music or the use of music in Scandinavia's prehistory. Furthermore, there were important differences of interpretation. Did Hammerich really mean that the long Stone Age (ca. 10,000-1800 BC) that preceded the period of the bronze lurs, i.e. the Bronze Age (ca. 1800-500 BC) was entirely lacking in music? No, most likely not. To be sure, Hammerich realised that

${ }^{6}$ One exception is Broholm, Larsen and Skjerne 1949, however this was a study of bronze lurs. 
there must have been different forms of organized sound production prior to the period of the bronze lurs, but he did not classify this as "music." Like so many others, he saw the bronze lurs through the lens of his period's conventional Western concept of music. When later on, the archaeologist H. C. Broholm expresses himself in a manner similar to Hammerich's, the terms "music" and "musical instruments" are defined in similarly conventional ways. ${ }^{7}$

\section{MUSIC ARCHAEOLOGY: THE GOLDEN ERA}

From the mid 1970s and during the 1980s I had my formal and economic music-archaeological base in Stockholm, under the auspices of the Music Museum together with the Royal Swedish Academy of Music. The initiative for this was taken in 1974 by the then director of the Music Museum, Gunnar Larsson, who in 1973 succeeded Ernst Emsheimer in that position.

\section{Exhibition and National Inventory}

In 1974 Gunnar Larsson asked me to create an exhibition at the Music Museum about prehistoric musical instruments found in the Nordic countries Denmark, Finland, Island, Norway and Sweden. It was de facto the first of its kind, and it was given the name The Sound of Archaeology. All five countries placed original musicarchaeological finds at the Museum's disposal (Lund 1974a; Lund 1974b). The great attention from the media-TV, Radio, presswas fruitful in promoting the field of music archaeology.

In 1975 Gunnar Larsson initiated a nation-wide, five year inventory project called The National Inventory (in Swedish Riksinventeringen), financed by the Bank of Sweden Tercentenary Foundation. Its purpose was to take stock and to document older musical instruments and other sound tools in Sweden up to the year 1900, including archaeological finds. Larsson continued the Music Museum's research tradition of organology established by Tobias Norlind, which was further continued and enhanced by his

\footnotetext{
7 Broholm 1965, 9: "They [the lurs] do not only represent the oldest instruments from our Continent..."
} 
successor as director of the Museum, Ernst Emsheimer. My musicarchaeological research, which was then in its infancy, was given a unique possibility-albeit with a time limit-to collect data in Sweden through the National Inventory. Archaeological collections of objects in the country's museums and storehouses were systematically examined. Certain and possible sound tools were documented and registered. They were classified according to two systems: as instrument types based on Hornbostel and Sachs (Hornbostel and Sachs 1914), and in five groups according to their probability for having been used for sound production, primarily or secondarily, based on a probability grouping. Group One includes objects which clearly are sound tools, such as bells and lyres. Others are possible sound tools, on a diminishing scale. Group Five includes objects with the lowest degree of probability (Fig. 5, see Lund 1980, 6-7; Lund 1981, 247).

The music-archaeological results of the Swedish National Inventory (here abbreviated RiMA) are accessible at the Music Museum in Stockholm both in the form of a systematic sheaf catalogue and extensive photo material (contact prints and negatives). RiMA also comprises archaeological finds from the Middle Ages and later periods, an area that a "newly-fledged" music archaeologist in 1975, Christian Reimers, came to be responsible for. The catalogue comprises in round figures one thousand objects. RiMA was a pioneer project and is, moreover, often cited as the most important and fruitful result of the whole National Inventory (Reimers 1977, 67-68; Reimers 1979, 109-12).

\section{International contacts: Berkeley 1977 and the Study Group of the International Council for Traditional Music}

Thanks to the outstanding international positions of the Music Museum and the Royal Swedish Academy of Music (through Gunnar Larsson, Hans Åstrand and not least Professor Emeritus Ernst Emsheimer), music archaeology in Sweden established valuable contacts with colleagues abroad, e.g. Ellen Hickmann, Graeme Lawson, Peter Holmes, Catherine Homo-Lechner, Bo Lawergren, to mention just a few of those scholars who have visited Stockholm on several occasions. I myself was sent out into the world, to various meetings and conferences, alone or supervised and guided by Ernst Emsheimer. 
It was at the International Musicological Society (IMS) Congress in Berkeley in 1977, that a round table took place for the first time under the heading of Music and Archaeology, that I first met Ellen Hickmann, an important personal encounter (Lund 1978, 199-200; Heartz and Wade 1981, 844-869). There in Berkeley, together with Anne Draffkorn Kilmer, Mantle Hood and Bathja Bayer, we sowed the seeds of a global contact organisation for music archaeology that later became The Study Group on Music Archaeology of the International Council for Traditional Music (ICTM). Thus having been born in Berkeley as an idea, a study group was founded in 1981 within the scope of the ICTM, a United Nations Educational, Scientific and Cultural Organization (UNESCO) body. This took place at the ICTM's (then the International Folk Music Council = IFMC) twelfth World Congress in Seoul. The founders were Ellen Hickmann, John Blacking, Mantle Hood and myself. A first meeting of this study group was held in Cambridge in 1982, hosted by Graeme Lawson. We were then eighteen people taking part in all or part of the meeting (Lawson 1983). ${ }^{8}$ The study group was formally constituted by the ICTM Directory and its Board in 1983 at the twenty seventh International ICTM Congress in New York (Lund 1986, 9). The second meeting of the study group took place in Stockholm in 1984. It was hosted by the Royal Swedish Academy of Music, and I was given the task to be the organiser, including the editing and publication of two conference volumes (Lund 1986; Lund 1987).

\section{Musica Sveciae}

As previously mentioned, The National Inventory was a project with a time limit. But at the same time that I was studying for a doctorate, now at Stockholm University, Hans Åstrand, the permanent secretary of the Royal Academy of Music, offered music archaeology a formal, and in part economic, base there from 1982 and for the next five years. One of the tasks was to create a

${ }^{8}$ Among the participants, I would like to mention Ernst Emsheimer, Laurence Picken, Frank Harrison, Joan Rimmer, Jeremy Montagu, Ann Buckley, Ellen Hickmann, Gunnar Larsson and Peter Holmes. 
gramophone record, including an extensive text booklet, with music and sounds from our prehistory within the framework of Musica Sveciae, Sweden's National Encyclopaedia of Music on Record. That resulted in Fornnordiska klanger/The Sounds of Prehistoric Scandinavia (Lund 1984; Lund 1991).

\section{Education of youth and adults}

Another activity during this so called golden era took place under the auspices of the Swedish as well as the Norwegian National Institutes for Concerts. Together with the musician and instrument maker Åke Egevad I went on tour for a couple of months every year throughout all of Sweden and Norway with programmes primarily for schoolchildren, but also for adults, about prehistoric instruments. This was a vital part of my own strategy to develop music archaeology, viz. to make the results of my research come alive for the general public-which should be the duty of every researcher-and to hope to obtain information from audiences about finds that are interesting from the viewpoint of music archaeology. One particularly rewarding ethno-musicarchaeological "by-product" of our work with schoolchildren (a total of ca. thirteen thousand children over the years) was the traditional information they were able to provide about sound tools such as buzz bones and bullroarers. These constitute finds from archaeological excavations, but the types survive even today, usually as toys. Many older people today recount stories about the making and the various social functions of these sound tools in former times. They generally pass this knowledge on to their grandchildren/great-grandchildren. Through schoolchildren with such inherited knowledge we could get in close contact with their grandparents or great-grandparents, and we were thus able to document what they had to tell. Such information is interesting to music archaeology because it stimulates analogies with the possible social functions of the sound tools in question, in prehistoric times (Lund 1980, 13; Lund 1985, 18-23).

\section{Music archaeology: an instrument for art and knowledge}

All the projects mentioned above were of limited duration. For that reason, when the South Swedish regional music institute Musik $i$ Syd offered me the chance to be responsible for the field of early 
music in 1987, I accepted the challenge. Music archaeology was thus given a new kind of platform, but without any larger scope for research and international activities concerning "extra-early music," i.e. music in prehistory. The main task was to produce both ordinary concert programmes and historical-pedagogical information programmes (including lectures, workshops, etc.) for adults as well as for children and young people. Here, I was given resources to initiate the Ensemble Mare Balticum (EMB), which would concentrate on early music up to the seventeenth century. This ensemble was formed on the basis of unique underwater archaeological finds of musical instruments on the wreck of the Royal Swedish flagship Kronan (The Crown), that went down in the Baltic Sea in 1676 (Fig. 6; see Lund 1986, 85-121; Westdeutscher Rundfunk Köln 1995, 12-25). The Ensemble Mare Balticum also lectures at the Musicology Department of the University in Lund for both undergraduates and graduates (Lund 2006, 16).

\title{
APPENDIX:
}

\section{THE KNOWN HISTORY}

\section{OF THE TERM "MUSIC ARCHAEOLOGY"} FROM AN INTERNATIONAL PERSPECTIVE

\begin{abstract}
In recent years terms like "music archaeology," "archaeomusicology," "musaeo-archaeology," etc., have gained permanency in the vocabulary of a fair amount of musicologists and archaeologists. The terms are often used as equivalents and it can be regretted that a closer definition for their employment has not yet been established. In the meantime it is not the place here to enter into a terminological discussion, and for the purpose at hand it suffices to point out that "music archaeology" was considered preferable in the present context, although not to the exclusion of "archaeomusicological"- the latter for practical/linguistic reasons. (De Geer 1985, 27)
\end{abstract}

As is evident from the quotation above, there are a number of equivalents in English to the Swedish term musikarkeologi; some other examples are "musical archaeology" and "palaeomusicology." There are no unequivocal definitions of the various terms (as De Geer quite rightly points out). Here I will present the 
history, as far as I know, of the Swedish term, as well as a selection of foreign variants.

\section{The use of terms before the 1980s}

As previously mentioned, the Swedish term musikarkeologi is used for the first time in 1880 in a speech by Carl Erik Södling (Södling 1880, 203). The next time that the term, to my knowledge, appears in Swedish is in 1964 - and this was entirely unrelated to Södlingin an article by the medical doctor, but later also an undergraduate archaeologist, Olle Henschen-Nyman (Henschen-Nyman 1964). For both Södling and Henschen-Nyman, the term indicates a collaboration between archaeologists and music historians. When the term was coined again, in 1974 at the Music Museum in Stockholm, it was also in ignorance of its earlier usage (Larsson 1974a, 3; Larsson 1974b, 4). ${ }^{9}$ When the term was introduced in my own papers (Lund 1977a, 49-66) it was primarily as an interdisciplinary indication, viz. that research on music in ancient times must necessarily be handled mainly by a combination of archaeological and musicological working methods and approaches (Lund 1980,1-13). When the field of research was introduced in 1977 in the national Swedish encyclopedia of music under the heading Musikarkeologi (Lund 1977b, 620), ${ }^{10}$ it was the very first time that the term appeared in any musicological or archaeological encyclopedia anywhere (Hickmann 1985, 2).

Outside the Scandinavian language sphere the equivalent French term (archéologie musicale) was in use in 1857 (Arbaud 1857). This term was used occasionally in nineteenth century French archaeological specialist literature. ${ }^{11}$ In 1919 the Russian musicologist Nikolai Findeizen was assigned to the chair of History of Music in Russia. His lectures included a course called "musical archaeology," музьикальная археология (mиsykal'naya arbeologija),

\footnotetext{
${ }^{9}$ See also footnote 1 above.

10 This Swedish encyclopedia is translated into Norwegian and Finnish.

11 Personal communication, Catherine Homo-Lechner, Paris. Cf. Schneider 1976, 89.
} 
however his sources were mainly historical and not archaeological (Findeizen 1928; see also Maes 2009, 691-693).

In the German-speaking world Zygmunt Estreicher seems to have been the first to use an equivalent term, Musikarchäologie, e.g. in an article concerning a work by Curt Sachs (Estreicher 1948, 348). Sachs' work in question deals with general, global theories for "Die Musik der alten Welt," however, without emphasis on ancient (non-literate) societies (Sachs 1943).

In scholarship written in English the term is touched upon by Kathleen Schlesinger several times, e.g. in 1930 in an editorial preface (Schlesinger 1930). In Paul Henry Lang's historical work Music in Western Civilization (1941) the term appears once. In his discussion of the performance practice of the Homeric hymns he points out that "[...] this constitutes the first great problem of musical archaeology" (Lang 1941, 6). It is not until 1964 that we encounter the English term "musical archaeology" again, and then it appears as the title of a popular science article about "Classicalmusic finds." The article was written by Fritz A. Kuttner, and was published in an American magazine (Kuttner 1964, 43-49; cf. Kuttner 1990). As was mentioned above, the same year (1964) Henschen-Nyman also uses the word musikarkeologi. I should add, too, that I have had the privilege of making the acquaintance of both Kuttner (died 1991) and Henschen-Nyman (died 1989). They have told me about their respective sporadic use of the term, and they also indicated that they did not know about each other's use of it, nor about its earlier use by anyone else.

A few years later (1967) the term reappears several times in a music-iconographical work by Emanuel Winternitz, for instance in a chapter heading "Musical Archaeology of the Renaissance in Raphael's Parnassus." There, Winternitz analyses ancient models for depictions of instruments in the Parnassus fresco (Winternitz 1967, chap. 14). Incidentally, a decade earlier he had used the Italian designation archeologia musicale in an article dealing with the very same Parnassus painting (Winternitz 1952-54).

The above-mentioned English-speaking researchers all used the term "musical archaeology" solely in discussions about music in Classical high cultures, for example Ancient Greece and Rome, Egypt and China. They also appear to use the term figuratively, however with a kind of chronological sense. That is to say, the word "archaeology" serves as a metaphorical paraphrase for 
"ancient times"; cf. Carl Dalhaus, as quoted in Hickman 1985, 34. Apart from Pierre Arbaud, whose profession I am not sure of, and the physician Henschen-Nyman, all of the persons mentioned above were musicologists. Their use of the term musikarkeologi or its foreign equivalent seems spontaneous and incidental.

The prehistorian who first made use of the term "musical archaeology" was Vincent Megaw in 1968 in a survey study of musical instruments from prehistoric Europe. Megaw, who says that he borrowed the term from above-mentioned Fritz A. Kuttner (1964), is of the opinion that the term is relevant as a designation of the field of prehistoric musical instruments. At the same time he introduces the synonymous term "palaeo-organology" (Megaw 1968, 1). Albrecht Schneider (a musicologist who is also educated in archaeology) applies Megaw's two terms alternately in a methodological article (Schneider 1976). A variant is found in a publication by André Buchner (Buchner 1980, 344), viz. "archaeoorganology." 12 This term is also used by Joan Rimmer (Rimmer 1981, 233).

Let me mention here, though it must be well-known to the reader, that the term "music/musical archaeology" both earlier and at present is rather often simply used in other contexts as a metaphor. Several examples can easily be found by means of a Google search on the web, such as "Brahms at the Piano, musical archaeology by Jonathan Berger, Stanford University: An analysis and transcription of the 1889 cylinder recording of Johannes Brahms piano performance of a segment from his First Hungarian Dance" (Berger 2009).

\section{Use of the term in the 1980s}

During the 1980s the term "music archaeology" started to show up more frequently in international contexts, mainly among ethnomusicologists. The establishment of the term amongst these researchers is bound up with the global contact organisation for music archaeologists the world over, with working conferences and

12 Buchner's definition of the term is "science on prehistoric musical instruments." 
publications on the agenda, viz. The Study Group on Music Archaeology of the ICTM, that was founded in the early 1980s (see above). Up until the group's formal constitution in 1983 its name was the Study Group on Archaeomusicology. However, at the request of ICTM's executive committee, "music archaeology" was substituted for "archaeomusicology" (I myself have used the term "archaeomusicology" now and then $\left.{ }^{13}\right)$. Both terms have from time to time been the subject of discussions and criticism by members of the Study Group and other interested parties. ${ }^{14}$

Mantle Hood had asked me the same year (1983) to try to describe the meaning of the term "music archaeology" on the basis of the various activities of the group members at the time. In this context, the term had various uses: ${ }^{15}$

(1) As a designation of a field (interdisciplinary studies regarding music and other non-linguistic sounds in extinct societies without a written language or with very little writing, i.e. antiquity and thus the major part of humanity's "music history").

(2) As a designation of a working method (musicology based on archaeological finds irrespective of their date, i.e. finds from both modern and ancient societies).

13 e.g. Lund 1981, and 1983. See also Hickmann 1983/84, and 2006.

${ }^{14}$ The Study Group on Music Archaeology of the ICTM held eight conferences between 1982-1996: Cambridge, UK 1982, Stockholm 1984, Hannover 1986, St. Germain-en-Lay 1990, Liège 1992, Istanbul 1993, Jerusalem 1994-95, Limassol, Cyprus 1996. The Conference Volumes are: Lawson 1983, Lund 1986-1987, Hickmann and Hughes 1988, HomoLechner, Bélis, Buckley and Picard 1994, Otte 1994, Hickmann and Eichmann 2000. A Bulletin was also published: Archaeologia musicalis (1-2/1987, 1-2/1988, 1-2/1989, 1/1990. Bulletin for the Study Group on Music Archaeology of the International Council for Traditional Music. Celle: Moeck Verlag). Ellen Hickmann founded another study group, with conferences since 1998, called the International Study Group on Music Archaeology (ISGMA). After an intermission the ICTM Study Group was revived in 2003. See also Both 2009, xi.

${ }^{15}$ For the original wording see Lund 1983/84, 3. 
(3) As a synonym of palaeo-organology (the study of musical instruments and other sound tools in antiquity).

The Swedish National Encyclopaedia states the following (here translated into English):

Musikarkeologi (English-Archaeomusicology, Music archaeology, German-Musikarchäologie, French-Archéologie musicale), since the 1980s the common generic term for such research which with interdisciplinary methods attempts to describe, explain and reconstruct music-and other nonlinguistic uses of sound (even whole soundscapes) - in historical as well as prehistoric societies on the basis of archaeological finds (Lund 1994, 519).

As is evident here, in Swedish (and Scandinavian) music archaeology, archaeological finds constitute the primary source (See Fig. 2; cf. Kolltveit 2006, 2-3).

\section{BIBLIOGRAPHY}

Andersson, O. (1930). The Bowed-Harp: a Study in the History of Early Musical Instruments, ed. Kathleen Schlesinger. London: W. Reeves. [Original in Swedish: Stråkharpan. En studie $i$ nordisk instrumenthistoria. Stockholm: Föreningen för svensk kulturhistoria, 1923].

(1934). "Nordisk musikkultur i äldsta tider." In: Nordisk Kultur, vol. 25: 1-23.

Arbaud, P. (1857). Archéologie musicale. Recherches sur la flûte ancienne. (Further details unknown).

Berger, J. (2009). https://ccrma.stanford.edu/groups/edison/ brahms/brahms. Accessed March 1, 2010.

Both, A. A. (2009). "Guest Editor's Preface: Special Section on Music Archaeology." Yearbook for Traditional Music 41: xi-xiv.

Broholm, H. C., W. P. Larsen, and G. Skjerne (1949). The Lures of the Bronze Age. An archaeological, technical and musicological investigation. Trans. A. Svart. Copenhagen: Gyldendal.

Broholm, H. C. (1965). Lurfundene fra bronzealderen. København: Nyt Nordisk Forlag.

Buchner, A. (1980). Colour Encyclopedia of Musical Instruments. London: Hamlyn. 
De Geer, I. (1985). Earl, Saint, Bishop, Skald_and Music. Uppsala: Institutionen för musikvetenskap, Uppsala universitet.

Estreicher, Z. (1948). "Ein Versuch der Musikarchäologie." Schweizerische Musikzeitung 88: 348-52.

Fétis, F.-J. (1869). Histoire générale de la musique. Paris: Didot.

Findeizen, N. (1928). History of Music in Russia from Antiquity to 1800, trans. S. W. Pring, ed. and annotated by M.Velimirović and C. R. Jensen. Vol. 1: From Antiquity to the Beginning of the Eighteenth Century. Russian Music Studies, ed. M. H. Brown, 2008. Bloomington: Indiana University Press.

Hackman, A. (1938). "Brandgräberfeld Pukkila: Rasseln." Finska Fornminnesföreningens tidskrift 41: 118-31.

Hammerich, A. (1893). "Studier over Bronzelurerne i Nationalmuseet i København." In: Aarboger for nordisk. Oldkyndighet og Historie 1893. II. Række, 8. Bind. Kjøbenhavn: Den Gyldendalske Boghandel: 141-90. [French translation, "Les lurs de 1'âge du bronze au musée de Copenhague." Mémoires de la Société des Antiquaires du Nord, trans. E. Beauvois. Copenhague: Libraire Gyldendal (1892): 137-68. German translation, "Studien über die altnordischen Luren." Vierteljahresschrift für Musikwissenschaft X, trans. unknown. Leipzig (1894): 1-32].

(1921). Dansk Musikbistorie indtil ca. 1700. København: G. E. C. Gad.

Heartz, D., and B. Wade, ed. (1981). "Music and Archaeology." With contributions by B. Bayer, C. Lafayette Boilès, E. Hickmann, M. Hood, A. Draffkorn Kilmer, Liang Ming-Yüeh, C. Lund, and R. L. Crocker. In: Report of the Twelfth Congress Berkeley 1977: International Musicological Society. Kassel: Bärenreiter: 844-69.

Henschen-Nyman, O. (1964). "Klang i Gävle museum." In: Arbetarbladet 15/7. Gävle.

Hickmann, E. (1983/84). "Terminology, Problems, Goals of Archaeomusicology." In: Progress Reports in Ethnomusicology 1, No. 3, ed. M. Hood. Department of Music, University of Maryland Baltimore County. (1985). "Musikarchäologie als Traditionsforschung." Acta Musicologica LVII, 1: 1-9. 
Hickmann, E., and D. Hughes, ed. (1988). The Archaeology of Early Music Cultures. Third International Meeting of the ICTM Study Group on Music Archaeology, Hannover 1986. Bonn: Verlag für systematische Musikwissenschaft $\mathrm{GmbH}$.

Hickmann, E., and R. Eichmann, ed. (2000). Stringed Instruments in Archaeological Context. Papers from the 8th International Meeting of the ICTM Study Group on Music Archaeology, Limassol 1996, and papers from the 7 th International Meeting of the ICTM Study Group on Music Archaeology, Jerusalem 1994-1995. Studien zur Musikarchäologie I, OrientArchäologie 6. Rahden/Westf: Marie Leidorf.

Hickmann, E. (2006), “Archaeomusicology.” In: Grove Music Online. Accessed August 2010.

Hildebrand, H. (1881). "En stridslur från den tidigare järnåldern." Kungl. Vitterhets-, historie- och antikvitetsakademiens manadsblad (KVHAA; from 1906 the journal's title was changed to Fornvännen). Stockholm: Månadsblad.

Homo-Lechner, C., A. Bélis, A. Buckley and F. Picard, ed. (1994). La pluridisciplinarité en l'archéologie musicale. 2 vols. 4th International Meeting of the ICTM Study Group on Music Archaeology, Saint Germain-en-Laye, 1990. Paris.

Hornbostel, E. M. von, and C. Sachs (1914). "Systematik der Musikinstrumente. Ein Versuch.” Zeitschrift für Ethnologie 1914: 553-90.

Jørgensen, S. (1956). "Kongemosen." In: Jysk Arkeologisk Selskabs årbok (KUML). Århus: 23-40.

Kolltveit, G. (2006). Jew's Harps in European Archaeology. British Archaeological Reports International Series 1500. Oxford: Hadrian Books Ltd.

Kuttner, F. A. (1964). "Classical-music finds." HiFi/Stereo Review 1964/13: 6. New York: 43-49.

(1990). The Archaeology of Music in Ancient China: 2,000 Years of Acoustical Experimentation 1400 B.C.A.D. 750. Minnesota: Paragon House.

Lang, P. H. (1941). Music in Western Civilization. New York. Larsson, G. (1974a). "The Sound of archaeology." In: Klang i flinta och brons. Stockholm: Musikmuseet: 3-4. 
Larsson, G. (1974b). "Introduction." In: The Sound of Archaeology. [English version of Larsson 1974a] Stockholm: Musikmuseet: 4.

Lawson, G. (ed.) (1983). Current research in European Archaeomusicology: summary and abstracts of a seminar on the archaeology of musical instruments. First International Meeting of the ICTM Study Group on Music Archaeology, Cambridge 1982. Music-Archaeological Report no. 6, August 1983. Cambridge: MusicArchaeological Research Project.

Lithberg, N. (1914). "Koskällan.” In: Fataburen 1914. Stockholm: Nordiska museet: 1-18.

Lund, C. S. (1972). Studier över förbistoriska musikinstrument i Norden [Prehistoric Musical Instruments in the Nordic Countries]. Undergraduate thesis. Arkeologiska institutionen, Lunds universitet.

(1974a). Klang i flinta och brons. Musikmuseet: Stockholm.

(1974b). The Sound of Archaeology. Stockholm:

Musikmuseet.

(1977a). "Nordisk musikarkeologi—en introduktion." Artes_tidskrift för litteratur, konst och musik 2/1977, ed. Ö. Sjöstrand. Stockholm: Forum: 49-66.

(1977b). "Musikarkeologi." In: Soblmans nya Musiklexion. Stockholm: Sohlmans Förlag AB: 620.

(1978). "Twelfth Congress of the International Musicological Society, Berkeley, California, U.S.A. August 21-27, 1977. Rapport gällande kongressens musikarkeologiska sektion." Fornvännen: Tidskrift för svensk antikvarisk forskning 1978/3: 199-200.

(1980). "Methoden und Probleme der nordischen Musikarchäologie." Acta Musicologica I/52: 1-13.

(1981). "The archaeomusicology of Scandinavia." World Archaeology 12/3 (issue: "Archaeology and musical instruments," ed. J. V. S. Megaw): 246-65.

(1983). "Abstract: Archaeomusicology in Sweden." In:

Current research in European Archaeomusicology: summary and abstracts of a seminar on the archaeology of musical instruments. 1 st International Meeting of the ICTM Study Group on Music Archaeology, Cambridge 1982. MusicArchaeological Report no. 6, August 1983, ed. 
G. Lawson. Cambridge: Cambridge MusicArchaeological Research Project: 1-3.

Lund, C. S. (1983/84). "About Music Archaeology: Its Concepts, approaches and philosophy." In: Progress Reports in Ethnomusicology 1/7, 1983-84, ed. M. Hood. Department of Music, University of Maryland Baltimore County: Baltimore, Maryland: 1-9.

(1984). Fornnordiska klanger/The Sounds of Prehistoric Scandinavia. LP med texthäfte/LP including a booklet. EMI, MS101. Stockholm: Musica Sveciae.

(1985). "Kinderklanggeräte und Musikarchäologie." In:

Studia instrumentorum musicae popularis VIII, ed.

E. Stockmann. Stockholm: Musikmuseet: 18-23. (ed.) (1986). General Studies. Second Conference of the ICTM Study Group on Music Archaeology, Stockholm 1984, Vol. I. Stockholm: Royal Swedish Academy of Music. (ed.) (1987). The Bronze Lurs. Second Conference of the ICTM Study Group on Music Archaeology, Stockholm 1984, Vol. II. Stockholm: Royal Swedish Academy of Music.

(1991). Fornnordiska klanger/The Sounds of Prehistoric Scandinavia. CD med texthäfte/CD including a booklet. MSCD101. Stockholm: Musica Sveciae. (Previous LP release: MS101, 1984.)

(1994). "Musikarkeologi." In: Nationalencyklopedin, Sverige:

Bra Böcker: 519.

(2006). "Ensemble Mare Balticum — ett instrument för konst och kunskap." Tidskrift för Tidig Musik 1: 16.

Maes, F. (2009). "About The History of Music in Russia from Antiquity to the Beginning of the Eighteenth Century, by Nikolai Findeizen (1868-1928)." Music \& Letters 90/4: 691-93.

Megaw, J. V. S. (1968). "Problems and non-problems in palaeoorganology: a musical miscellany." In: Studies in ancient Europe: essays presented to Stuart Piggott, ed. J. M. Coles and D. D. A. Simpson. Edinburgh University Press: 333358.

(1988). “The Emperor's New Clothes: The New Music Archaeology?" In: The Archaeology of Early Music Cultures. Third International Meeting of the ICTM Study Group on Music Archaeology, Hannover 1986, ed. E. Hickmann and 
D. W. Hughes. Bonn: Verlag für systematische Musikwissenschaft GmbH: 343-53.

Moberg, C.-A. (1951). "Från kämpevisa till locklåt." Svensk Tidskrift för Musikforskning 1951: 5-52.

Moeck, H. (1955). "Die Skandinavischen Kernspaltflöten in Vorzeit und Tradition der Folklore." Svensk tidskrift för musikforskning 1955: 56-83.

Nerman, B. (1937). "Vartill har Balkåkrapjäsen använts?" Fornvännen: Tidskrift för svensk antikvarisk forskning 4: 193202.

Nihlén, J. (1927). Gotlands stenåldersboplatser. Stockholm: Kungl

Vitterhets Historie och Antikvitets Akademiens handlingar 36: 3.

Nilsson, S. (1838). Skandinaviska Nordens ur-invanare, vol. I. Lund: Berlingska boktryckeriet. [English trans. by John Lubbock The primitive inhabitants of Scandinavia, London: Longmans, Green, and Co., 1868].

Norlind, T. (1947). Bilder ur svenska musikens bistoria, vol. 1. Stockholm: Musikhistoriska museet.

Ohlson, G. (1967). Studier över gravmaterial från stenålderslokalen på Ire, Hangvar sn, Gotland. PhL dissertation. Stockholm: Arkeologiska institutionen, Stockholms universitet.

Oldeberg, A. (1947). "A Contribution to the History of the Scandinavian Bronze lur in the Bronze and Iron Age." Acta Archaeologica XVIII: 1-91.

(1950). "Vallhorn, herdepipor och lurar." Värmland forr och nu XLVIII: 19-67.

Otte, M. (ed.) (1994). Sons Originels: Préhistoire de la musique. Actes du colloque de musicologie. Fifth International Meeting of the ICTM Study Group on Music Archaeology, Liège 1992. Études et recherches archéologiques de l'Université de Liège 61. Liège

Panum, H. (1915, 1928, 1931). Middelalderens strengeinstrumenter og deres forlobere $i$ oldtiden. Three volumes: I/1915, II/1928, III/1931. København: Lehmann \& Stage.

Petersen, J. (1917). "Paa rangel. Smaa studier i museene." In: Oldtiden. Festskrifte til Haakon Schetelig paa 40-aarsdagen 25.juni 1917. Kristiania: Oldtiden: 35-40. 
Reimers, C. (1977). "Riksinventeringen och musikarkeologin." Artes-tidskrift for litteratur, konst och musik 2/1977, ed. Ö. Sjöstrand. Stockholm: Forum: 67-68.

(1979). "Riksinventeringen av äldre svenska musikinstrument, ett redskap för musikarkeologin." Fornvännen: Tidskrift för svensk antikvarisk forskning 1979/2: 109-112.

Rimmer, J. (1981). "An archaeo-organological survey of the Netherlands." World Archaeology 12/3 (issue: "Archaeology and musical instruments," ed. J. V. S. Megaw): 233-42.

Rydh, H. (1931). Stora Karlsö under forntiden. Stockholm: Karlsö jagtoch djurskyddsförening.

Sachs, C. (1943). The Rise of Music in the Ancient World East and West. New York: Norton.

Salin, B. (1922). 'Fyndet från Broa i Halla, Gotland.' Fornvännen: Tidskrift för svensk antikvarisk forskning 1922: 189-206.

Schlesinger, K. (1930). Editorial preface in the English translation of Otto Andersson's doctoral thesis Sträkharpan 1923, published in 1930 as The Bowed Harp: a Study in the History of Early Musical Instruments. London: W. Reeves.

Schneider, A. (1976). "Möglichkeiten der paläoorganologischen Forschung." In: Studia instrumentorum musicae popularis, ed. E. Emsheimer. Stockholm: Musikhistoriska museet: 8894.

(1986). "АРХАIO $\Lambda$ ОГЕ $\Omega$. Some comments on methods and sources in music archaeology." In: Lund 1986: 195224.

Schween, J. (2004). Verehrt und mißbraucht-Zur Rezeptionsgeschichte der bronzezeitlichen Luren im 19. und 20. Jahrhundert.' In: Studien zur Musikarchäologie IV, Orient-Archäologie 15, ed. E. Hickmann and R. Eichmann. Rahden/Westf.: Marie Leidorf: 193-220.

Shetelig, H. and F. Johannessen (1929). Kvalsundfundet og andre norske myrfund av fartoier. Bergens museums skrifter, ny raekke. Bergen: Bergens museum.

Skjerne, G. (1949). The Lures of the Bronze Age by H. C. Broholm et.al. Chap. IV, V and VI. Copenhagen: 71-129. 
Södling, C. E. (1876). "Speeches at the Meeting of the Swedish Antiquarian Society 1875." Svenska Fornminnesföreningens Tidskrift 8/1876: 111-12, 124-25, 133. (1880). "Speech at the Meeting of the Swedish Antiquarian Society 1980." Svenska Formminnesföreningens Tidskrift 12: 203-4.

Thomsen, C. J. (1836). Ledetraad til Nordisk Oldkyndighet. København.

Westdeutscher Rundfunk Köln. (1995). Tage alter Musik in Herne 1995, Mare Balticum Konzerte. Stadt Herne und Westdeutscher Rundfunk: 12-25.

Vestergaard Nielsen, S. (1951). "Blokfløjter fra oldtid og middelalder." In: Jysk Arkeologisk Selskabs årbok (KUML). Århus: 145-52.

Widstrand, C. G. (1948). Förhistoriska musikinstrument. Undergraduate thesis in archaeology. Department of Archaeology, University of Stockholm.

Winternitz, E. (1952-54). "Archeologia Musicale del Rinascimento nel Parnaso di Raffaello." In: Rendiconti della Pontificia Accademia Romana di Archeologia 27: 359-388. (1967). Musical Instruments and their Symbolism in Western Art. New York: W.W. Norton.

Wiora, W. (1961). "Musikgeschichte und Urgeschichte." Svensk tidskrift för musikforskning: 375-96. 

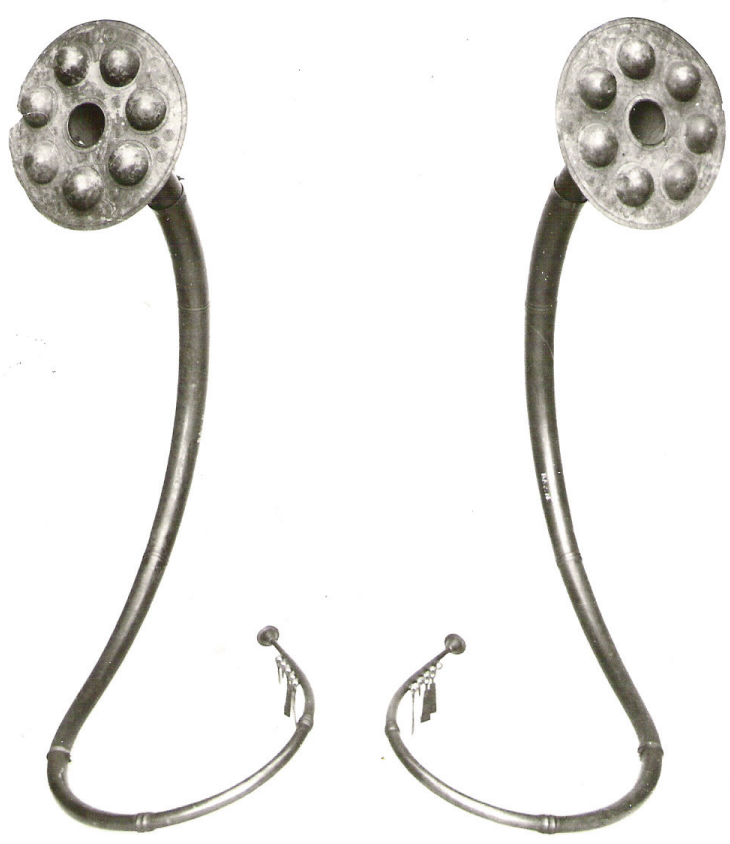

Fig. 1. Two of the six bronze lurs (ca. 3000-2500 years old) that were found at Brudevaelte, Denmark in 1797.

Total length ca. $2.20 \mathrm{~m}$. Photograph reproduced by kind permission of the National Museum, Copenhagen. 


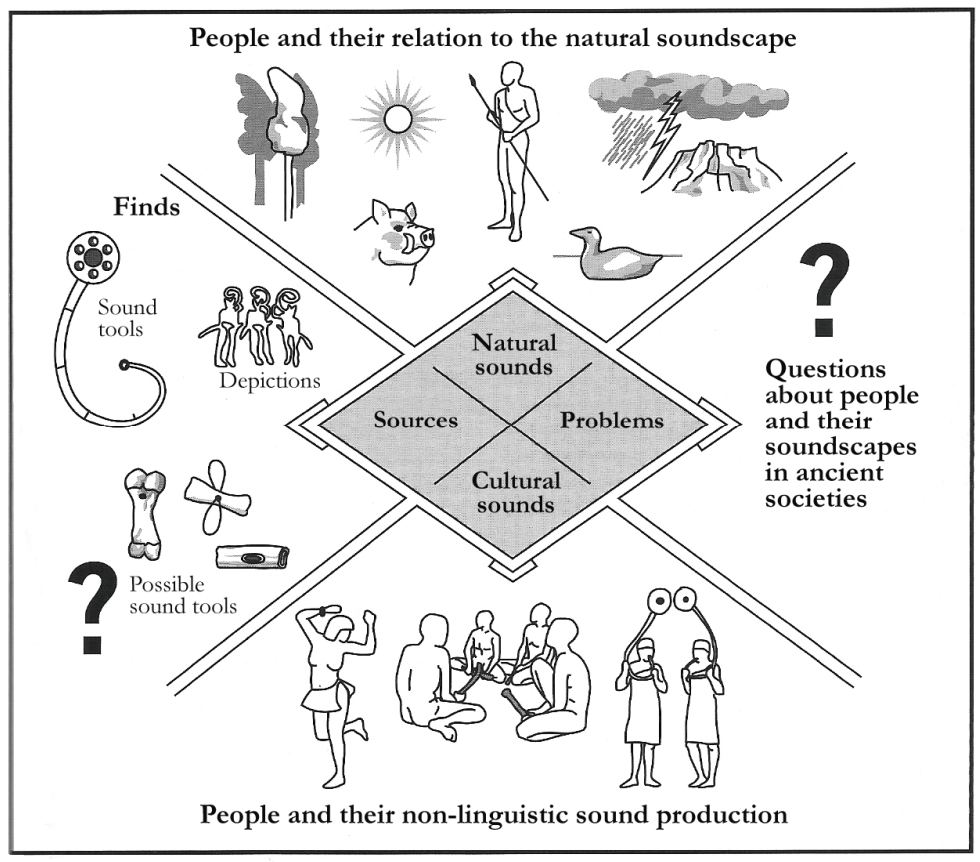

Fig. 2. The Scandinavian model of music archaeology: the constituent fields of research as illustrated by the author. 


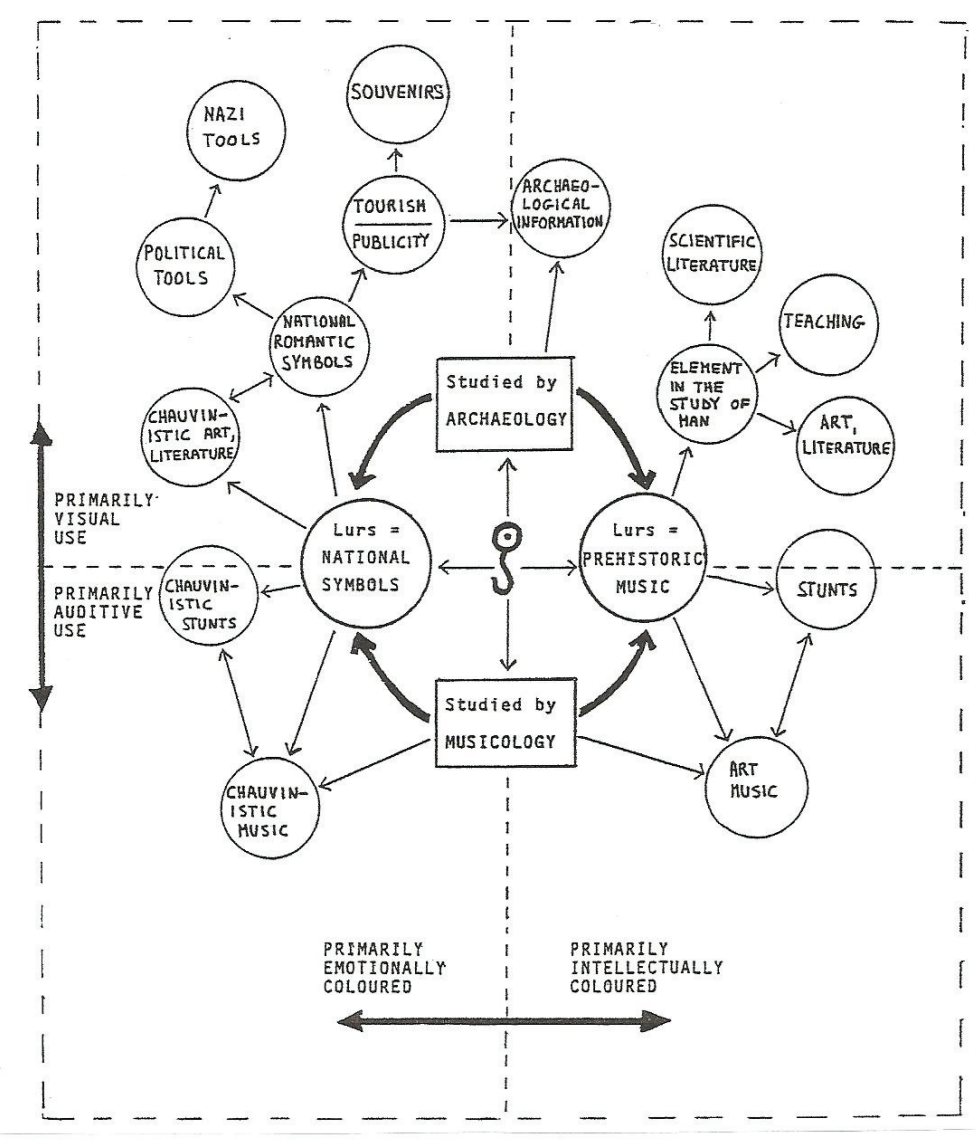

Fig. 3. The latter-day use of the ca. 3000-2500 year old bronze lurs as illustrated by the present author. After Lund 1987, 44. See also Schween 2004, 193-220. 


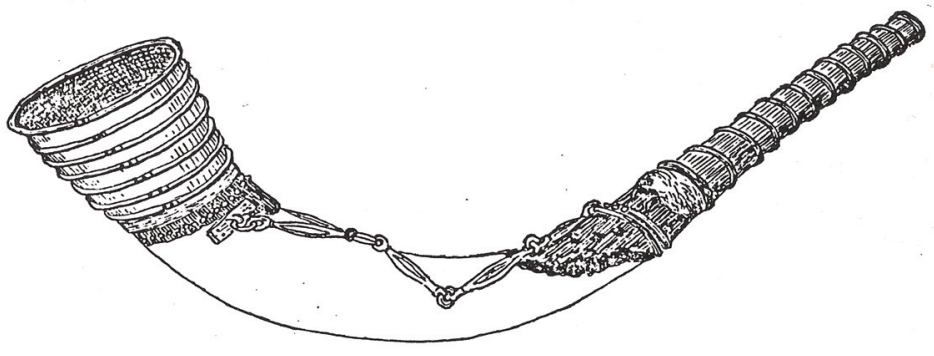

Fig. 4. Ox horn with bronze additions on both ends plus a carrying chain of bronze.

It was found in the nineteenth century in a bog at Barva, Sweden and is dated to the early Iron Age.

Length: ca. $85 \mathrm{~cm}$. After Lund 1987, 27.

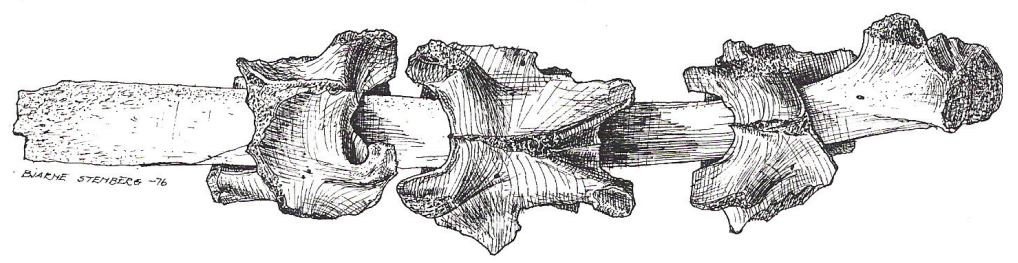

Fig. 5. Pierced bones from an ox tail threaded on a rib.

The artefact was found close to a medieval house (dated to ca. 1250-1350) in the city of Tønsberg, Norway. Length: ca. $18.5 \mathrm{~cm}$.

The object's function is unknown. It is classified by the present author as a possible rattle within Group

Five of the so called probability grouping

(Lund 1980, 6-7; Lund 1981, 247).

The artefact's location is Vestfold Fylkesmuseum,

Tønsberg, catalogue number TL 2204b.

Drawing: Bjarne Stenberg, reproduced by kind permission of Riksantikvaren, Distriktskontor Syd, Tønsberg. 

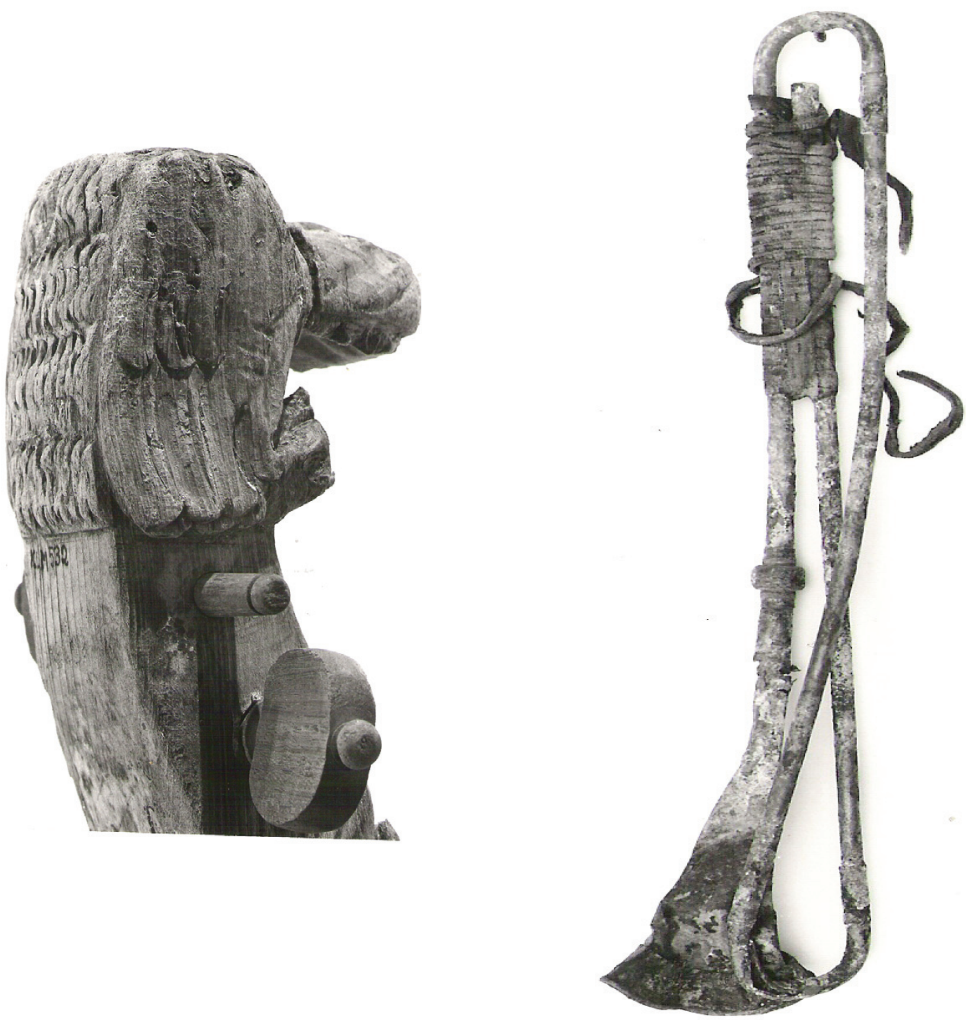

Fig. 6. Two of the musical instruments found on the wreck of the Royal Swedish Flagship Kronan (the Crown), that went down in the Baltic Sea in 1676: detail from part of a bass viola da gamba (left), and a natural trumpet (right). The trumpet was made and signed by Michael Nagel, Nürnberg, in 1654. Photograph reproduced by kind permission of the Kalmar läns museum/Kronanprojektet. 